UNIVERSIDADE DE SÃO PAULO

ESCOLA DE ENFERMAGEM

MARIA MARTA NOLASCO CHAVES

\title{
COMPETÊNCIA AVALIATIVA DO ENFERMEIRO \\ PARA O RECONHECIMENTO E ENFRENTAMENTO \\ DAS NECESSIDADES EM SAÚDE DAS FAMÍLIAS
}

SÃO PAULO 
MARIA MARTA NOLASCO CHAVES

\section{COMPETÊNCIA AVALIATIVA DO ENFERMEIRO \\ PARA O RECONHECIMENTO E ENFRENTAMENTO \\ DAS NECESSIDADES EM SAÚDE DAS FAMÍLIAS}

Tese apresentada ao Programa de
Pós-Graduação Interunidades EEUSP-
EERP, da Escola de Enfermagem da
Universidade de São Paulo, para
obtenção do título de Doutor em
Enfermagem.

Área de concentração:

Saúde Coletiva

Orientadora:

Prof. ${ }^{a}$ Dr. ${ }^{a}$ Emiko Yoshikawa Egry 
AUTORIZO A REPRODUÇÃO TOTAL OU PARCIAL DESTE

TRABALHO, POR QUALQUER MEIO CONVENCIONAL OU

ELETRÔNICO, PARA FINS DE ESTUDO E PESQUISA, DESDE QUE CITADA A FONTE.

Assinatura: Data:

\section{Catalogação na Publicação (CIP)}

Biblioteca "Wanda de Aguiar Horta"

\section{Escola de Enfermagem da Universidade de São Paulo}

Chaves, Maria Marta Nolasco

Competência avaliativa do enfermeiro para o reconhecimento e enfrentamento das necessidades em saúde das famílias. / Maria Marta Nolasco Chaves. - São Paulo, 2010.

$271 \mathrm{p}$.

Tese (Doutorado) - Programa Interunidades EE-EERP da Universidade de São Paulo.

Orientadora: Prof. ${ }^{a}$ Dr. ${ }^{a}$ Emiko Yoshikawa Egry

1. Competência profissional 2. Enfermeiros 3. Necessidades e demanda de serviços de saúde 4 . Saúde pública 5 . Atenção à saúde I. Título 
Nome: Maria Marta Nolasco Chaves

Título: Competência avaliativa do enfermeiro para o reconhecimento e enfrentamento das necessidades em saúde das famílias.

Tese apresentada ao Programa de Pós-Graduação Interunidades EEUSPEERP, da Escola de Enfermagem da Universidade de São Paulo, para obtenção do título de Doutor em Enfermagem.

Aprovado em:

Banca Examinadora

Prof. Dr.

Instituição:

Julgamento:

Assinatura:

Prof. Dr.

Julgamento:

Instituição:

Assinatura:

Instituição:

Assinatura:

Julgamento:

Prof. Dr.

Instituição:

Julgamento:

Assinatura: 
Ao Paulo, meu companheiro, pelo carinho, apoio e incentivo em todas as horas.

Aos meus filhos Beatriz e Henrique, pelo carinho e compreensão nas longas ausências. 


\section{AGRADECIMENTOS}

À Prof. ${ }^{a}$ Dr. $^{a}$ Emiko Yoshikawa Egry, pela confiança, pelo incentivo, pela compreensão, pela amizade e pela orientação para o desenvolvimento desta pesquisa.

Ao Prof. Dr. Jaime Breilh, pelas orientações, pelo incentivo, pelos cuidados, pela amizade e pelos bons tempos equatorianos desta caminhada.

Ao CNPq, pelo apoio ao desenvolvimento das atividades de pesquisa por meio de bolsa de formação de pesquisador de doutorado.

À Escola de Enfermagem da Universidade de São Paulo, pelo compromisso com a formação e qualificação dos profissionais da enfermagem.

Ao Departamento de Enfermagem da Universidade Federal do Paraná, pelo apoio e incentivo.

À Universidad Andina Simon Bolívar, pelo apoio para o período sanduíche desta caminhada.

À Secretaria Municipal de Saúde de Curitiba-PR, pelo apoio para a realização do estudo.

Ao Conselho Municipal de Saúde de Curitiba, pela disponibilidade de material e pelo apoio recebido.

Aos Professores da Escola de Enfermagem da Universidade de São Paulo, pelo incentivo ao desenvolvimento de conhecimentos e pelo carinho recebido.

Aos Professores e funcionários do Departamento de Saúde Coletiva da Escola de Enfermagem da Universidade de São Paulo, pelo apoio, pela amizade e pelos cuidados recebidos.

Aos docentes e discentes do Curso de Enfermagem da Universidade Federal do Paraná, pela compreensão e pelo apoio recebido.

Aos companheiros da área de Saúde Coletiva do Curso de Enfermagem da UFPR, Liliana, Laura, Paulo e Sandra, pelo apoio e pelo incentivo. 
Aos colegas do grupo de pesquisa do Departamento de Saúde Coletiva da EE-USP coordenado pela Prof. ${ }^{a}$ Dr. ${ }^{a}$ Emiko Yoshikawa Egry, Maíra, Paula, Lara, Tânia, Dora, Rebeca, Tereza, Cecília, Gil, Ana Paula, Jaqueline, Caroline e Renata, pelos processos de aprendizagens na pesquisa.

A Márcia Cubas e Cláudia Marques, pela disponibilidade e pelas contribuições imprescindíveis.

Ao Comitê de Ética da Escola de Enfermagem da Universidade de São Paulo, pelo apoio e pelas orientações.

À Coordenadora de Enfermagem da SMS-CTBA, enfermeira Msc. Soriane, pelo apoio e disponibilidade.

Aos gestores e funcionários do Distrito Sanitário Boa Vista, pelo apoio para o desenvolvimento deste estudo.

Aos funcionários, residentes e amigos da Universidad Andina Simon Bolívar pelo carinho, apoio e cuidados no período em que estivemos juntos, especialmente à Ylonka, Maria Luiza e Sandra, companheiras nos trabalhos junto ao Departamento de Saúde da UASB.

Às alunas Talitha e Vanessa, bolsistas do Grupo de Pesquisa GEFASEDUFPR, pelo carinho e pelo apoio na digitação dos relatórios das Conferências Municipais de Saúde de Curitiba-PR.

À amiga Maria Luiza, pela generosidade, pelo carinho e sinceridade em todas as horas.

Às colegas Verônica e Elizabeth Bernardino, pelas orientações de veteranas na Pós-graduação da EE-USP no início desta jornada.

Aos sujeitos da pesquisa, pela disponibilidade e rica contribuição para o presente estudo.

Aos amigos e familiares que acompanharam e incentivaram esta caminhada. 
Não haveria criatividade sem a curiosidade que nos move e que nos põe pacientemente impacientes diante do mundo que não fizemos, acrescentando a ele algo que fazemos.

Paulo Freire 
Chaves MMN. Competência avaliativa do enfermeiro para o reconhecimento e enfrentamento das necessidades em saúde das famílias [Tese]. São Paulo: Escola de Enfermagem da Universidade de São Paulo; 2010.

\section{RESUMO}

Estudo exploratório, descritivo com abordagem qualitativa sobre a competência avaliativa do enfermeiro para reconhecer e enfrentar as necessidades em saúde das famílias. Ancorado na Teoria da Intervenção Práxica da Enfermagem em Saúde Coletiva (TIPESC). Objetivou identificar qual a competência avaliativa do enfermeiro para o reconhecimento e o enfrentamento das necessidades em saúde das famílias em um determinado território; listar as ações do enfermeiro na atenção básica para reconhecimento e enfrentamento das necessidades em saúde; evidenciar as temáticas das situações em que são reconhecidas e enfrentadas necessidades em saúde das famílias descritas pelo enfermeiro; descrever o conjunto de ferramentas que o enfermeiro mobiliza nas situações de reconhecimento e enfrentamento de necessidades em saúde segundo as contradições dialéticas nos discursos empíricos e analíticos para o reconhecimento e enfrentamento das necessidades em saúde das famílias de um determinado território; identificar, segundo as temáticas evidenciadas, os saberes avaliativos do enfermeiro da atenção básica para o reconhecimento e enfrentamento das necessidades em saúde das famílias. O local do estudo foi o Distrito Sanitário Boa Vista em Curitiba-PR. Os dados foram coletados em fontes primárias e secundárias. Os sujeitos da pesquisa foram vinte e cinco enfermeiras que trabalhavam nas Unidades de Saúde que aceitaram participar da entrevista. Nos resultados sobre a caracterização de Curitiba se verificam processos de determinação das necessidades em saúde nas condições de vida da população; as propostas de intervenção em saúde aprovadas nas Conferências estiveram baseadas na concepção do risco à saúde com enfoque para intervenções curativistas para reverter os índices epidemiológicos relacionados aos agravos identificados em estudos; os protocolos e programas vigentes estão fundamentados na epidemiologia do risco e orientam intervenções para a prevenção dos adoecimentos por meio de mudanças no estilo de vida e do autocuidado, sendo a recuperação dos doentes relacionada à adesão ao tratamento com a corresponsabilidade dos profissionais nos processos; as compreensões das enfermeiras sobre as necessidades em saúde reconhecidas, enfrentadas e os recursos utilizados para intervir foi convergente com as normatizações vigentes na SMS e com as propostas de intervenções aprovadas nas Conferências Municipais de Saúde. A discussão dos resultados permitiu a identificação dos saberes avaliativos do enfermeiro da atenção básica necessários para reconhecer e intervir segundo as necessidades em saúde das famílias de um determinado território. As considerações finais indicam que a enfermeira reconhece processos determinantes das necessidades em saúde e do processo saúde-doença nas diferentes dimensões da realidade, singular, particular e estrutural, porém ao intervir não os relaciona e direciona suas ações para a dimensão singular. Os recursos que as enfermeiras mobilizaram para as intervenções foram coerentes com a concepção biológica e individual do processo saúde-doença e os programas foram reconhecidos como potencializadores para o acesso aos insumos e materiais necessários. Esta concepção foi convergente com a implantação do Sistema Único de Saúde municipal, pois este avançou no sentido de implantar um sistema integrado, hierarquizado, regionalizado e resolutivo para questões relacionadas aos agravos identificados nos índices epidemiológicos. Os desafios apontados são no sentido de formar profissionais para reconhecerem os determinantes das necessidades em saúde percebidas pelas famílias e pelos usuários moradores da área de abrangência dos serviços de saúde local e, assim, reverter o atual modelo de intervenção.

PALAVRAS-CHAVE: Competência profissional. Enfermeiros. Necessidades em saúde. Saúde coletiva. Atenção básica em saúde. 
Chaves MMN. Nurse's assessment competence to acknowledge and cope with family health needs [Thesis]. São Paulo: Nursing School of University of São Paulo; 2010.

\section{ABSTRACT}

Descriptive exploratory study with a qualitative approach on nurse's assessment competence to acknowledge and cope with family health needs. It is grounded on the Theory of Praxis Intervention in Collective Health Nursing (TIPESC in portuguese). It aimed to identify nurse's assessment competence in order to acknowledge and cope with family health needs in a given coverage area; to list nurses' actions on primary care for acknowledgement and coping with health needs; to evidence the thematic of situations where family health needs - described by nurses - are acknowledged and coped; to describe the set of tools used by nurses in situations of acknowledgement and coping with health needs according to dialectic contradictions in empirical and analytical accounts for the acknowledgement and coping with family health needs in a given coverage area; to identify, according to the evidenced thematic, nurses' assessment knowledge on primary care in order to acknowledge and cope with family health needs. The study venue was Boa Vista Sanitary District in Curitiba/ Parana State, Brazil. Data collection was carried out through primary and secondary sources. Research subjects were twenty-five nurses who worked at Health Units and agreed to participate in the interview. In the results on Curitiba featuring, the processes to determine health needs in the population living conditions are verified; health intervention proposals approved in the Conference were based on the health-risk conception focused on healing interventions to reverse epidemiological rates related to conditions identified in the studies; protocols and programs in effect are grounded on risk epidemiology and guide interventions to prevent diseases by means of changes in lifestyle as well as self-care, being patients recovery related to treatment compliance along with professionals' coresponsibility in the processes; nurses' understanding on acknowledged and coped health needs as well as the used intervention resources converge with the current norms by the Municipal Health Service and the intervention proposals approved by the Municipal Health Conference. Result discussion enabled to identify nurses' necessary assessment knowledge on primary care in order to acknowledge and intervene according to family health needs in a given coverage area. Final considerations point out that nurses recognized determinant processes on health needs and health-disease process in the different realms of reality, singular, particular and structural although they do not relate them during intervention and guide their actions towards the singular dimension. Nursing intervention resources conformed to individual and biological conception of the health-disease process while the programs were ac knowledged as potential-ridden to the access to the necessary supplies and materials. This conception conforms to the implementation of the municipal Integrated Health System once it went forth the implementation of an integrated, hierarchic, regionalized and problem-solving system to the issues related to conditions identified in the epidemiological rates. The pointed challenges objectify to educate professionals who can acknowledge determinants to health needs perceived by families and users living in the coverage area of local health services and, thus, reverse the current intervention model.

KEY-WORDS: Professional competence. Nurses. Health Needs. Collective Health. Primary Health Care. 


\section{LISTA DE ILUSTRAÇÕES}

Figura 1 - Esquema ilustrativo da tomada de iniciativa do profissional no trabalho

Figura 2 - Representação da composição e localização geográfica da mesorregião metropolitana de Curitiba no estado do Paraná .... 116

Figura 3 - Distribuição do percentual das AlHs, por especialidade e procedência do usuário nos serviços de internamento do Sistema Único de Saúde de Curitiba-PR - 1996

Figura 4 - Atendimentos e procedimentos odontológicos na rede municipal de saúde de Curitiba-PR, no período de 1992 a 2002, Curitiba-PR

Figura 5 - Percentual de crescimento de consultas médicas na rede municipal de saúde de Curitiba, no período de 1985 a 2006, Curitiba- PR - 2009

Figura 6 - Distribuição de bairros segundo regional administrativa no município de Curitiba-PR - 2008.

Figura 7- Regional Administrativa Boa Vista no município de Curitiba, segundo crescimento populacional no período de 1996 a 2000

Figura 8 - Representação gráfica das pirâmides populacionais do município de Curitiba e Regional Boa Vista - Curitiba-PR 2005

Figura 9 - Representação gráfica da área de abrangência do "Linhão do Emprego" no Município de Curitiba-PR - 2008

Figura 10 - Representação gráfica do uso do solo no município de Curitiba-PR com destaque para a Regional Boa Vista Curitiba-PR - 2005

Figura 11 - Localização das áreas com ruas não oficiais, assentamentos sem regularização, assentamentos em regularização, loteamentos clandestinos sem regularização e loteamentos 
clandestinos em regularização na Regional Boa Vista Curitiba-PR - 2005

Figura 12 - Representação gráfica da renda média do chefe do domicílio, segundo setor censitário, na Regional Boa Vista no município de Curitiba-PR - 2005

Figura 13 - Distribuição dos equipamentos de saúde na Regional Boa Vista - Curitiba-PR - 2008

Figura 14 - Distribuição dos equipamentos comunitários de abastecimento na Regional Boa Vista - Curitiba- PR - 2005

Figura 15 - Distribuição do número de participantes, delegados, convidados e observadores, nas Conferências Municipais de Curitiba-PR no período de 1997 a 2007

Figura 16 - Síntese da ação do enfermeiro na atenção básica no processo de reconhecer e enfrentar as necessidades em saúde 


\section{LISTA DE QUADROS}

Quadro 1 - Temas de propostas nas Conferências Municipais de Saúde de Curitiba do período de 1997 a 2007, segundo as dimensões da realidade - estrutural, particular e singular, Curitiba- PR - 2009

Quadro 2 - Análise do discurso nos protocolos vigentes na Secretaria Municipal de Saúde - Curitiba-PR - 2009

Quadro 3 - Núcleos de sentido do discurso das enfermeiras sobre como reconhecem necessidades em saúde das famílias moradoras nas áreas de abrangências sob suas responsabilidades agrupados segundo subtema Curitiba-PR - 2009

Quadro 4 - Núcleos de sentido do discurso das enfermeiras sobre as necessidades em saúde reconhecidas nas famílias moradoras nas áreas de abrangências sob suas responsabilidades agrupados segundo subtema Curitiba-PR - 2009. 186

Quadro 5 - Núcleos de sentido do discurso das enfermeiras sobre as intervenções promovidas para enfrentar necessidades em saúde das famílias moradoras nas áreas de abrangências sob suas responsabilidades agrupados segundo subtema Curitiba-PR - 2009.

Quadro 6 - Núcleos de sentido do discurso das enfermeiras sobre os recursos para reconhecer e enfrentar as necessidades em saúde das famílias moradoras nas áreas de abrangências sob suas responsabilidades agrupados segundo subtema Curitiba-PR - 2009

Quadro 7 - Saberes avaliativos do enfermeiro da atenção básica necessários para avaliação e enfrentamento de necessidades em saúde das famílias 


\section{LISTA DE TABELAS}

Tabela 1 - Cobertura vacinal de rotina em população menos de um ano, segundo o tipo de vacina aplicada, no período de 1984 a 2006, em Curitiba-PR.

Tabela 2 - Distribuição dos serviços de saúde do município, segundo tipo e quantidade de unidades - Curitiba - 2009.

Tabela 3 - Distribuição dos leitos cadastrados em Curitiba na Central Metropolitana de Leitos Hospitalares, públicos, filantrópicos e privados, disponíveis nos anos de 2004 e 2006 Curitiba-PR - 2009

Tabela 4 - Profissionais lotados na Secretaria Municipal de Saúde de Curitiba, segundo categoria e quantidade - Curitiba- 2009 


\section{LISTA DE SIGLAS}

$\begin{array}{ll}\text { ACS } & \text { - Agente Comunitário de Saúde } \\ \text { CAPS } & \text { - Centro de Atendimento Psicossocial } \\ \text { CEAS } & \text { - Centro de Estudos e Assessoria em Saúde } \\ \text { CEMEI } & \text { - Centro Municipal de Educação Infantil } \\ \text { CEMUM } & \text { - Centro de Municipal de Urgências Médicas } \\ \text { CIPESC } 8) & \text { - Classificação Internacional das Práticas de Enfermagem em } \\ & \text { Saúde Coletiva } \\ \text { CIPE } & \text { - Classificação Internacional das Práticas de enfermagem } \\ \text { CTBA } & \text { - Curitiba } \\ \text { EEUSP } & \text { - Escola de Enfermagem da Universidade de São Paulo } \\ \text { ESF } & \text { - Estratégia Saúde da Família } \\ \text { ECOS-PIA } & \text { - Espaços de Contraturno Socioambiental do Programa de } \\ & \text { Integração da Infância e Adolescência } \\ \text { FMI } & \text { - Fundo Monetário Internacional } \\ \text { HC - UFPR } & \text { - Hospital de Clínicas da Universidade Federal do Paraná } \\ \text { IPPUC } & \text { - Instituto de Pesquisa e Planejamento Urbano de Curitiba } \\ \text { IPARDES } & \text { - Instituto Paranaense de Desenvolvimento Econômico e Social } \\ \text { IBGE } & \text { - Instituto Brasileiro de Geografia e Economia } \\ \text { IDH-M } & \text { - Índice de Desenvolvimento Humano do Município } \\ \text { MHD } & \text { - Materialismo Histórico Dialético } \\ \text { ONG } & \text { - Organização Não Governamental } \\ \text { NOB/96 } & \text { - Norma Operacional Básica de 1996 } \\ \text { PIA } & \text { - Programa de Integração da Infância e Adolescência } \\ \text { PIA } & \text { - População em Idade Ativa } \\ \text { PNUD } & \text { - Programa das Nações Unidas } \\ \text { PACS } & \text { - Programa de Agente Comunitário de Saúde } \\ \text { PEA } & \text { - População Economicamente Ativa } \\ \text { POC } & \text { - População Ocupada } \\ \text { PSF } & \text { - Programa Saúde da Família } \\ \text { SAMU } & \text { - Serviço de Atendimento Médico de Urgência } \\ & \end{array}$


SESA - Secretaria Estadual de Saúde do Paraná

SMS - Secretaria Municipal de Saúde

SIATE - Serviço Integrado de Atendimento ao Trauma em Emergência

UASB - Universidad Simón Bolívar

UFPR - Universidade Federal do Paraná

USP - Universidade de São Paulo

US - - Unidade de Saúde

SIAVSUS - Sistema de Informação Hospitalar do Sistema Único de Saúde

SIAB - Sistema de Informação da Atenção Básica

SUS - Sistema Único de Saúde

TIPESC - Teoria da Intervenção Práxica da Enfermagem em Saúde Coletiva

TCLE - Termo de Consentimento Livre Esclarecido 


\section{SUMÁRIO}

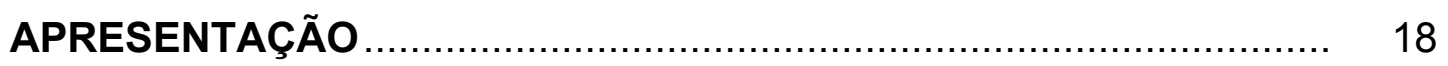

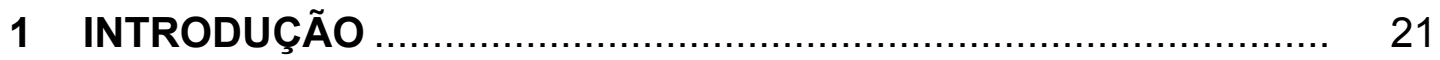

2 DELIMITAÇÃO DO PROBLEMA ………………....................... 28

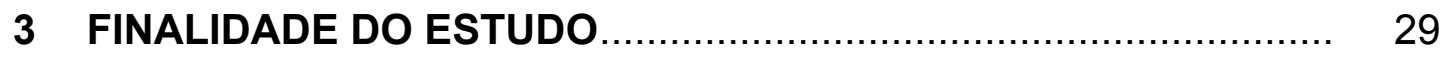

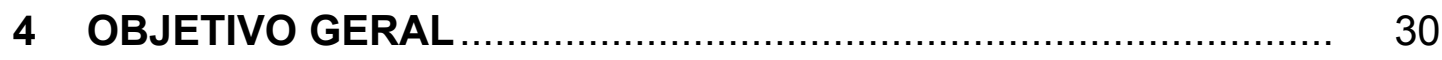

4.1 OBJETIVOS ESPECÍFICOS .................................................. 30

5 BASE TEÓRICA E PRESSUPOSTOS CONCEITUAIS .................... 31

5.1 NECESSIDADES .......................................................... 31

5.2 EPIDEMIOLOGIA: A CONSTRUÇÃO DO OBJETO PARA INTERVENÇÃO EM SAÚDE COLETIVA ………........................ 41

5.2.1 As concepções teóricas na epidemiologia: do mágicoreligioso à racionalidade científica moderna........................ 42

5.2.2 A teoria da determinação social do processo saúdedoença e a intervenção em saúde coletiva ............................ 51

5.3 SERVIÇOS DE SAÚDE: PLANEJAMENTO E PROGRAMAÇÃO NA DEFINIÇÃO DA INTERVENÇÃO ........................................... 56

5.4 PARTICIPAÇÃO POPULAR NA DEFINIÇÃO DE DIRETRIZES PARA AS POLÍTICAS PÚBLICAS DE SAÚDE

5.4.1 Os movimentos sociais no Brasil: a construção da participação popular na definição de Políticas Públicas....... 67

5.4.2 A participação popular no Sistema Único de Saúde.............. 74

5.4.3 A consolidação da democracia no setor saúde .................... 80

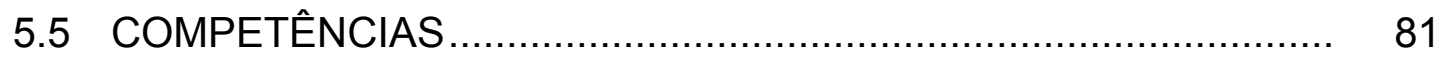

5.5.1 Educação e competência ................................................ 92

5.5.2 Competência profissional .............................................. 96

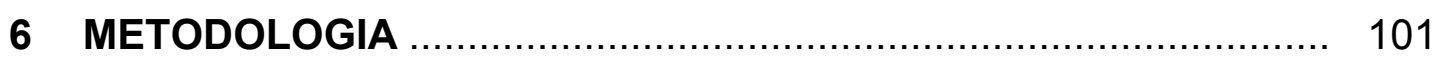

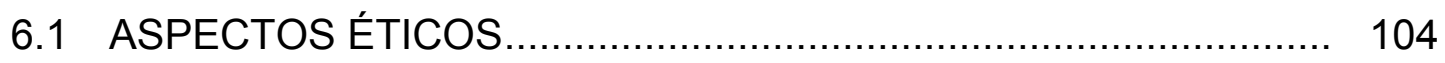

6.2 COLETA DE DADOS EMPÍRICOS ............................................ 105

6.3 COLETA DE DADOS SECUNDÁRIOS ……............................... 107

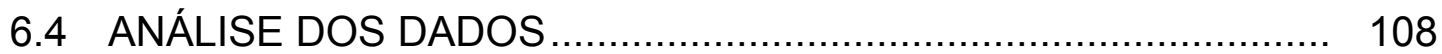


7.1 O MUNICÍPIO DE CURITIBA ................................................ 112

7.1.1 Características geográfica, populacional, econômica e social.... 114

7.1.2 Educação, emprego e renda ............................................. 120

7.1.3 Indicadores epidemiológicos ......................................... 122

7.1.4 Os serviços de saúde em Curitiba ...................................... 137

7.1.5 Organização administrativa de Curitiba e da Regional Boa Vista

7.1.6 Aspectos populacionais e econômicos na Regional Boa Vista 150

7.1.7 Equipamentos públicos na Regional Boa Vista 152

7.2 AS CONFERÊNCIAS MUNICIPAIS DE SAÚDE - DEZ ANOS DE PARTICIPAÇÃO DO MOVIMENTO SOCIAL ORGANIZADO NA ELABORAÇÃO DE INTERVENÇÕES EM SAÚDE.

7.2.1 Aspectos relevantes nos temas das propostas aprovadas..... 156

7.2.2 A organização das Conferências e o número de participantes ... 168

7.3 OS PROTOCOLOS - O DISCURSO DA SECRETARIA MUNICIPAL DE SAÚDE PARA A INTERVENÇÃO EM SAÚDE .....

7.4 O DISCURSO DO ENFERMEIRO PARA RECONHECER E ENFRENTAR AS NECESSIDADES EM SAÚDE DAS FAMÍLIAS COM OS RECURSOS DISPONIVVEIS

8 DISCUSSÃO

8.1 O RECONHECIMENTO DAS NECESSIDADES EM SAÚDE ......... 198

8.2 AS NECESSIDADES EM SAÚDE RECONHECIDAS .

8.3 O ENFRENTAMENTO DAS NECESSIDADES EM SAÚDE RECONHECIDAS

8.4 OS RECURSOS UTILIZADOS PARA O ENFRENTAMENTO DAS NECESSIDADES EM SAÚDE RECONHECIDAS.

8.5 A COMPETÊNCIA AVALIATIVA DO ENFERMEIRO PARA O RECONHECIMENTO E ENFRENTAMENTO DAS NECESSIDADES EM SAÚDE NA ATENÇÃO BÁSICA À SAÚDE ............................. 238

9 CONSIDERAÇÕES FINAIS ................................................. 240

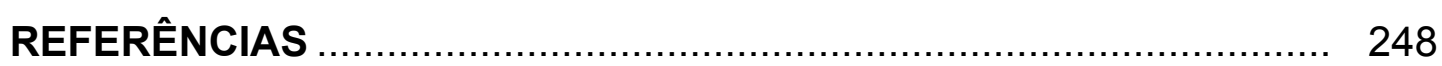


APÊNDICE A - RAPPORT

APÊNDICE B - TERMO DE CONSENTIMENTO LIVRE E ESCLARECIDO (TCLE)

APÊNDICE C - ROTEIRO PARA ENTREVISTAS SEMI-

ESTRUTURADAS

APÊNDICE D - SABERES E SIGNIFICADOS DO SABER-SER ÉTICO PROFISSIONAL DO ENFERMEIRO DA ATENÇÃO BÁSICA NECESSÁRIOS PARA A AVALIAÇÃO E ENFRENTAMENTO DE NECESSIDADES EM SAÚDE DAS FAMÍLIAS

ANEXO A - PARECER DO COMITÊ DE ÉTICA DA ESCOLA DE ENFERMAGEM DA UNIVERSIDADE DE SÃO PAULO .... 268 ANEXO B - PARECER DO COMITÊ DE ÉTICA DA SECRETARIA MUNICIPAL DE SAÚDE DE CURITIBA 


\section{APRESENTAÇÃO}

A experiência profissional, tanto na assistência à saúde como na formação de enfermeiros e outros profissionais de saúde, despertou-me o interesse para a temática e o objeto deste estudo. Em tais experiências, muitas vezes, percebi o empenho do enfermeiro para o desenvolvimento de intervenções em saúde coletiva que, em muitos casos, não modificavam os determinantes da realidade de saúde enfrentada. Em pouco tempo, o que se percebia era que as intervenções realizadas não eram resolutivas, mas representavam alívio aos sinais, sintomas e queixas dos usuários.

Baseada nessa reflexão, desenvolvi a pesquisa junto ao programa de mestrado. Buscava perceber a compreensão sobre o processo saúde-doença que havia em uma comunidade agroindustrial próxima à localidade onde atuava como docente. A começar desta construção de conhecimento outras foram possíveis, por meio de projetos de pesquisa, de extensão e de ensino. Nestes, procurava encontrar respostas que me ajudassem a compreender a realidade na qual são desenvolvidas as assistências de enfermagem em Saúde Coletiva.

Em alguns momentos, parecia-me que as determinações das questões de saúde apresentadas pela população estavam distante daquilo que era percebido pelos profissionais. Assim, nas intervenções, seguiam-se padrões normatizados por programas ou até mesmo se percebia que havia restrição pelos poucos recursos materiais disponíveis para serem aplicados. Neste caso, ao desenvolver a intervenção, não eram discutidas as razões que impunham tais limitações no trabalho e na assistência.

Ao longo desse período, tive a oportunidade de exercer a coordenação de um programa de residência multiprofissional na Universidade Federal do Paraná (UFPR) e, assim, participar da construção de uma nova forma de aprender, ensinar e intervir em saúde coletiva. Essa experiência acentuou as minhas reflexões sobre as necessidades em saúde expressas pela população e como estas eram percebidas e consideradas para a construção de uma proposta de intervenção em saúde, neste caso, com enfoque multiprofissional. 
Assim, mais uma questão foi somada às minhas reflexões, qual é a preparação que os profissionais de saúde têm para reconhecer e enfrentar as necessidades em saúde dos usuários de serviços da Atenção Básica.

Outra argumentação que se junta a essas reflexões é sobre a forma de organização dos Serviços de Saúde a qual atende aos pressupostos das Políticas Públicas de Saúde no Sistema Único de Saúde (SUS) que referenda os princípios de igualdade, universalidade, integralidade, resolubilidade, entre outros. Entretanto, os profissionais destes Serviços de Saúde não conseguem desenvolver intervenções que atendam às necessidades em saúde da população sob sua responsabilidade. Ao contrário, seguem prescritivamente os critérios dos programas implantados.

Com toda essa inquietação, busquei delimitar aquela que fosse norteadora no meu processo de qualificação, neste caso, no Programa de Doutorado Interunidades da Universidade de São Paulo. Assim, consciente de que não terei respostas para todas as inquietações expostas, julguei necessário buscar uma metodologia que me permitisse construir estas respostas e, principalmente, que eu pudesse contribuir para a intervenção do enfermeiro em saúde coletiva, pois, além de ser esta a minha formação acadêmica, ainda é a área na qual atuo como docente.

Durante o processo de qualificação no Programa de Doutorado tive a oportunidade de acrescentar uma experiência que me permitiu refletir ainda mais sobre estas mesmas inquietações. Realizei um período sanduíche na Universidade Andina Simon Bolívar (UASB), na cidade de Quito-Equador, sob orientação do Professor Doutor Jaime Breilh11. A oportunidade foi significativa na construção do presente estudo, principalmente no que refere à determinação

\footnotetext{
1 Médico, equatoriano, doutor em Epidemiologia pela Universidade Federal da Bahia, doutor honoris causa da Universidad Nacional de Cajamarca, Peru. Diretor do Departamento de Salud de la Universidad Andina Simon Bolívar. Diretor do Centro de Estudos e Assessoria em Saúde (CEAS), Quito, Equador e, da Mestría Internacional en Salud con Enfoque de Ecosistemas nas Universidades de Columbia Britânica, Canadá; Cuenca, Machala y Bolívar. Fundador e Coordenador da Comisión Andina sobre Determinantes Sociales de la Salud. É um dos fundadores do movimento da Saúde Coletiva na América Latina. Estudioso sobre a determinação social do processo saúde doença. Autor de vários livros publicados e premiados.
} 
do objeto selecionado para esta investigação. O período foi de sessenta e cinco dias, nos quais tive oportunidades únicas, tais como: acompanhar o desenvolvimento de pesquisa junto à comunidade; desenvolver estudos sobre o estado da arte da enfermagem equatoriana e sobre os referenciais teóricos utilizados pelas Comissões de Investigação dos Determinantes Sociais em Saúde nos casos brasileiros e andinos; apresentar os dados coletados e previamente analisados desta pesquisa para o grupo de docentes do Departamento de Saúde da UASB; conhecer a realidade da enfermagem daquela cidade e promover um evento para que professoras do Departamento de Saúde Coletiva da Escola de Enfermagem da Universidade de São Paulo (EEUSP) apresentassem a experiência deste na investigação em enfermagem em saúde coletiva com a presença de profissionais, estudantes e professores de diferentes universidades daquele país.

Como desdobramento dessa experiência, no mês de janeiro desse ano, ocorreu uma oficina promovida pelo Departamento de Saúde da UASB, coordenada pelo Professor Doutor Jaime Breilh para a elaboração do Curso de Mestrado em Enfermagem em Saúde Coletiva com o apoio do Departamento de Enfermagem em Saúde Coletiva da EEUSP-SP. Estiveram presentes na oficina as Professoras Doutoras Emiko Yoshikawa Egry, Rosa Maria Godoy Serpa da Fonseca, a Cirurgiã Dentista Mestra Claudia da Silva Marques (Ministério da Saúde) e, ainda, representantes de diversas Instituições de Ensino Superior do Equador.

Portanto, com essa caminhada e reflexões construí o conhecimento que está organizado em nove capítulos apresentados a seguir. 


\section{INTRODUÇÃO}

A Constituição Federal de 1988, no artigo 196, regulamenta a saúde como direito de todo cidadão e dever do Estado. Para garanti-la, estabelece que seja por adoção de políticas sociais e econômicas que visem à redução dos riscos de doença e outros agravos. E, ainda, que o acesso aos serviços e ações de saúde é universal e igualitário. Para desenvolver a atenção à saúde dos indivíduos ou da coletividade, as práticas sanitárias deverão privilegiar as ações de promoção e proteção da saúde (Brasil, 1988).

Nesse sentido, para avançarmos nas mudanças necessárias e efetivar o estabelecido na Constituição, foi regulamentada a Lei n. ${ }^{\circ} 8.080 / 90$ como a política pública para o setor, que regula, em todo o território nacional, suas ações e serviços, assim como aqueles serviços que lhes serão complementares, em caráter temporário ou permanente. Esse momento histórico na saúde pública brasileira foi resultado de um movimento social organizado que teve início na década de 1970.

Foram vários anos de luta em que políticos, profissionais de saúde e a população organizada defenderam as mudanças que buscaram garantir a implementação de práticas nas quais a saúde é vista como direito do cidadão, e ainda, que o processo saúde-doença é determinado pelo desgaste do indivíduo na sua inserção no processo de produção e, consequentemente, nas relações que ele estabelece na sua reprodução social. Logo, para o desenvolvimento da assistência à saúde, deve-se compreender que assistir é ir além do desenvolvimento de cuidados para os usuários que apresentarem queixas, sinais e sintomas nas demandas espontâneas nos serviços de saúde (Chaves, 2000).

Campos (1997) refere que a assistência à saúde é compreendida como o desenvolvimento de cuidado para a manutenção da vida com qualidade, ao longo do ciclo de vida dos indivíduos, respeitando-se, pois, as diferenças de cada realidade. A intervenção para o enfrentamento das questões apresentadas deverá considerar os seus determinantes e condicionantes, portanto, não se restringe ao motivo imediato que gerou a demanda no serviço de saúde. 
Refletir sobre o desenvolvimento de práticas sanitárias, segundo a compreensão de saúde exposta acima, faz pensar sobre o modelo de assistência que é desenvolvido atualmente e que tem a proposta, pelo movimento da reforma sanitária, de ser revertido. Para tal, pressupõe-se que a formação de profissionais para a área da saúde deverá articular os conhecimentos científicos com a realidade do processo saúde-doença da população, assim como articular com os movimentos sociais para a compreensão da determinação da realidade de saúde com o objetivo de referendar novas maneiras de se desenvolver o processo de trabalho em saúde,

Ao analisar fatores críticos para a produção de serviços em saúde, Pierantoni (2003) afirma que a formação de profissionais de saúde no Brasil teve um grande avanço quantitativo nos últimos anos, porém, aponta contradições dos aspectos qualitativos desta formação. Atribui essa contradição a fatores que são relacionados aos conteúdos, nas graduações e ensinos técnicos, que são concentrados nas bases biológicas que privilegiam as discussões de doenças e intervenções medicamentosas para os agravos.

Para Egry (1996), Mendes (1999) e Mendes-Gonçalves (1992), a possibilidade de enfrentamento das questões de saúde da população está no reconhecimento das necessidades em saúde dos grupos, famílias ou comunidades e nas especificidades que conformam a realidade observada para que se proponham intervenções mais resolutivas. Assim, para se efetivar uma nova forma de atuar, é necessário que os profissionais reflitam sobre a realidade observada e os seus determinantes. Mediante tais reflexões, acredita-se que os indivíduos (profissionais e usuários) possam ser capazes de articular e desenvolver as mudanças tanto na vida como no trabalho em saúde.

No Brasil a década de 1990 é reconhecida por Campelli e Calvo (2007) e Paim (2003), como um retrocesso histórico no avanço de direitos do cidadão que se conquistara na Constituição de 1988. Os autores destacam ainda que nesse período as Políticas Públicas adotadas permitiram o retrocesso do papel do Estado no setor saúde e incentivaram o avanço do modelo de assistência privativa em contraposição ao crescimento da cobertura dos serviços públicos na atenção básica. 
Para Mendes (1999), é o descrédito no modelo de assistência à saúde vigente que leva a população a buscar modelos alternativos, bem como a comprar serviços privados para obter uma solução às questões que tem de enfrentar para possuir melhor condição de saúde.

Mendes-Gonçalves (1992) refere que os trabalhos em saúde são processos específicos que encontram seus objetos e necessidades na realidade social historicamente determinada. Portanto, eles não têm "[...] dados invariantes internos a si próprios, nenhum objeto 'natural' e nenhuma necessidade 'natural' [...]" (p.26), ao contrário, referenda a sua determinação social e histórica.

Egry (1996) afirma que o processo saúde-doença é expresso diferentemente para cada classe social, pois é um processo de desgaste biológico pela inserção dos indivíduos no processo de produção e nas relações de reprodução social. Acrescenta que em uma sociedade estratificada por classes sociais "[...] a qualidade de vida de cada classe social é diferente, pois diferente é sua exposição aos processos de risco e ao acesso a processos benéficos ou potencialidades de saúde [...]" (p.61).

Para Merhy (2003, p.80):

\begin{abstract}
A centralidade dos usuários, individuais e coletivos, vem de seu território de identidade como aqueles que gastam sua vida de certos modos e não outros, que usam sua capacidade de viver para produzir modos de caminhar na vida, sendo a saúde esta possibilidade de criar seus mecanismos de gastar a potência de viver. Logo, como produtores e portadores das necessidades de saúde.
\end{abstract}

Mendes-Gonçalves (1992) afirma que o homem é um ser natural, que pode ser descrito pelas suas necessidades e poderes e nestes dois aspectos observa-se um constante movimento de mudanças e desenvolvimento.

Conhecer as necessidades é para Schraiber e Mendes-Gonçalves (1996) reconhecer os carecimentos da vida cotidiana e o modo como determinados grupos se organizam para continuar a vida, tendo como premissa que os técnicos não detêm o conhecimento de todas as necessidades que podem ser expressas nas diferentes formas de organização social. Cabe, a começar daí, reconhecer as necessidades daquela realidade e, assim, incluir formas 
de enfrentamento nos processos de produção em saúde. Para Egry (1996), é fundamental a busca da compreensão dos fenômenos com reflexão crítica para identificação das contradições que o conformam. A reflexão sobre esta realidade permitirá encontrar, pela historicidade do fenômeno, os pontos de vulnerabilidade que possibilitariam a construção de uma proposta de intervenção.

O trabalho na concepção marxista permite-nos compreender a sua estrutura no contexto social mais amplo e na sua dimensão histórica. Entende-se que o processo de trabalho é a ação do ser humano sobre determinado objeto, utilizando suas capacidades mentais e físicas para transformá-lo. Marx (1985, p.202) define que o trabalho é um "[...] processo de que participam o homem e a natureza, processo em que o ser humano com sua própria ação impulsiona, regula e controla seu intercâmbio material com a natureza [...]". Assim, para produzir bens e objetos, para a transformação deste em um produto, o homem necessita de energia, da sua força de trabalho e do uso de instrumentos adequados à finalidade construída em sua mente.

Para Egry (1996), a prática em saúde coletiva é uma interferência consciente na realidade objetiva que é anteriormente planejada com uma visão crítica-reflexiva em que se identificam as necessidades em saúde, suas determinações e as possibilidades de ações.

As necessidades em saúde para Mendes-Gonçalves (1992, p.29) são compreendidas como:

[...] aspectos da vida humana ligados à estrutura de normatividade que se vai constituindo, e passa assim a ser responsável pela execução do trabalho separado de resolver problemas que, chamem-se ou não de 'doenças', implicam restrições na capacidade humana de viver a vida tal e qual vinha sendo vivida, e assim avaliados como negativos, constituem-se em necessidades de saúde. [...]

A competência do enfermeiro para a intervenção em saúde coletiva, segundo Faustino (2004), é um processo que se inicia na formação e que deverá ir além do saber-fazer; deve incorporar a competência ético-moral para desenvolver, no futuro profissional, atitudes que o habilite e o comprometa com a transformação social. 
Ramos (2002, p.281) analisa os pressupostos de competência para o mundo do trabalho e afirma que este:

[...] ocorre pelo fato de os novos processos de produção demandarem do trabalhador não somente conhecimento técnico, mas também e fundamentalmente, que seus atributos subjetivos sejam postos em jogo na realização das atividades profissional. Assim, a dimensão experimental da qualificação, que faria pelo apelo à subjetividade do trabalhador [...]. A noção de competência expressaria coerentemente essa dimensão, pois seu significado psicológico chamaria a atenção para as capacidades cognitivas e sócio-afetivas também mobilizadas pelos trabalhadores na realização de suas atividades profissionais.

Para Faustino (2004), a formação do enfermeiro tem sofrido transformações nos últimos anos, para promover um processo que permite a este profissional desenvolver críticas e reflexões que intervêm na realidade do cotidiano da enfermagem e ser agente de sua transformação. Para a autora, desde as recomendações das diretrizes curriculares de 1996, a enfermagem brasileira discute as competências necessárias para o seu exercício profissional.

As modificações nos modelos de qualificação, nesse caso formação, são desenvolvidas socialmente e se modificam em períodos longos de suas histórias. Zarifian (2003) afirma que as modificações podem ser ordenadas pelos movimentos vindos do trabalho, da profissão e independente da origem desse movimento de mudança, sabendo-se que ele é longo e socialmente determinado. Logo, segundo o autor, o profissional não estará totalmente preparado em uma única fase, pois será em suas situações concretas do trabalho que o trabalhador poderá mobilizar as ferramentas que possui no sentido de ser resolutivo nos eventos que enfrentará. Para o enfermeiro, a graduação permite o desenvolvimento da capacidade de reflexão e intervenção no sentido de transformar as realidades indesejadas para a saúde das pessoas e comunidades. Posteriormente, em sua prática profissional se torna agente de transformação dessas realidades, assim como da sua própria prática.

Egry (1996) propõe a Teoria da Intervenção Práxica da Enfermagem em Saúde Coletiva (TIPESC) que fundamenta a sistematização para captar e interpretar um fenômeno observado na realidade objetiva, baseada no referencial teórico do Materialismo Histórico Dialético (MHD). A autora toma como categorias dimensionais a totalidade, a práxis e a interdependência das dimensões 
estrutural, particular e singular do fenômeno. Para a captação e a interpretação do fenômeno, referenda que o reconhecimento da determinação de tal fenômeno é pela compreensão da sua própria articulação com o processo de produção e reprodução social. Considera que a intervenção em saúde modifica a realidade referindo que esta deverá ser novamente interpretada para seguir no movimento contínuo de interpretação e reinterpretação, para captar a 'nova realidade' que se apresentará a cada momento, tornando a intervenção um processo articulado, contínuo e resolutivo ao tomar a determinação social do processo saúde-doença no seu aspecto histórico e social.

Para o Conselho Nacional de Secretários de Saúde (Brasil, 2003, p.16), a realidade brasileira é definida por diversas contradições que se apresentam por:

[...] múltiplas determinações sobre o estado de saúde da população e dos indivíduos; diversidade das necessidades de saúde em uma população; diferentes tipos de ações e serviços necessários para dar conta dessas necessidades; capacitação de pessoal e recursos tecnológicos requeridos para atendê-las; interesses e pressões do mercado na área da saúde (no âmbito da comercialização de equipamentos, medicamentos, produção de serviços, entre outros) que freqüentemente tensionam a estruturação de um sistema calcado na concepção de saúde como um direito de cidadania [...]

Em Curitiba, cidade onde foi desenvolvida esta pesquisa, a enfermagem desenvolve intervenções em saúde para usuários inscritos nos programas de atenção à saúde da mulher e da criança, segundo o sistema de Classificação Internacional das Práticas de Enfermagem em Saúde Coletiva (CIPESC $®$ ). O uso do sistema possibilita a consolidação de dados sobre os Diagnósticos e Intervenções utilizadas pelo profissional na consulta de Enfermagem. As informações geradas nesses procedimentos também contribuíram para fundamentar o presente estudo, pois, ao orientar o desenvolvimento de pesquisa que utilizou a consolidação dos dados da base (CIPESC®), foi possível refletir sobre o trabalho do enfermeiro na atenção básica no município. Outra questão relevante é a vinculação deste estudo ao projeto de pesquisa intitulado "O trabalho da enfermagem em saúde coletiva - as necessidades e vulnerabilidades como objetos de intervenção e a apropriação dos saberes instrumentais", que tem sido desenvolvido em dois municípios: Curitiba e 
São Paulo, sob a orientação da Professora Doutora Emiko Egry, também orientadora da presente proposta.

O território, neste estudo, é a área de abrangência do Distrito Sanitário Boa Vista, região norte do município de Curitiba-PR, no qual a organização do trabalho dos enfermeiros, nas unidades de atenção básica, dispõe de registros informatizados para os atendimentos à mulher e à criança nas consultas de enfermagem segundo o CIPESC $囚$.

O conjunto de diagnósticos e intervenções que disponibiliza o sistema informatizado permite investigar as ferramentas que são mobilizadas pelo profissional para o reconhecimento e enfrentamento de necessidades em saúde das famílias naqueles territórios. Tem-se ainda que nesse distrito outras investigações foram realizadas pelo grupo de pesquisa, no qual esta proposta está inserida, com resultados que permitem aprofundar a análise dos dados encontrados e que este Distrito Sanitário oferece campos para estágios de disciplinas do Curso de Enfermagem da Universidade Federal do Paraná, no qual a pesquisadora é docente na área de saúde coletiva.

A reflexão sobre necessidades em saúde, trabalho, processo de trabalho em saúde, intervenções do enfermeiro na atenção básica para atender às necessidades em saúde e as três dimensões das competências saber-saber avaliar, saber-fazer avaliar e saber-ser ético profissional mobilizadas para a avaliação permite evidenciar a importância das temáticas para se discutir a competência avaliativa do enfermeiro para o reconhecimento e enfrentamento das necessidades em saúde das famílias que estão sob sua responsabilidade em um determinado território, pois as questões que emergem nesta discussão repercutirão sobre o processo de formação deste profissional, assim como na organização do seu processo de trabalho. 


\section{DELIMITAÇÃO DO PROBLEMA}

Diante do exposto, e reafirmando as contradições existentes no processo de trabalho do enfermeiro em saúde coletiva, para desenvolver competência(s) que possibilitaria $(m)$ o reconhecimento e o enfrentamento das necessidades em saúde das famílias é que se pergunta:

Quais as ferramentas que o enfermeiro mobiliza na competência avaliativa no sentido de reconhecer e enfrentar as necessidades em saúde das famílias em determinado território? 


\section{FINALIDADE DO ESTUDO}

A presente pesquisa teve por finalidade contribuir para a prática do enfermeiro em saúde coletiva, a partir da identificação da(s) ferramenta(s) que o enfermeiro mobiliza na competência avaliativa para o reconhecimento e o enfrentamento das necessidades em saúde das famílias em um determinado território. 


\section{OBJETIVO GERAL}

Identificar qual a competência avaliativa do enfermeiro para o reconhecimento e o enfrentamento das necessidades em saúde das famílias em um determinado território.

\subsection{OBJETIVOS ESPECÍFICOS}

- Listar as ações do enfermeiro na atenção básica, no município de Curitiba-PR, para reconhecimento e enfrentamento das necessidades em saúde.

- Evidenciar as temáticas das situações em que são reconhecidas e enfrentadas necessidades em saúde das famílias descritas pelo enfermeiro.

- Descrever o conjunto de ferramentas que o enfermeiro mobiliza nas situações de reconhecimento e enfrentamento de necessidades em saúde, segundo as contradições dialéticas, nos discursos empíricos e analíticos para o reconhecimento e enfrentamento das necessidades em saúde das famílias de um determinado território.

- Identificar, segundo as temáticas evidenciadas, os saberes avaliativos do enfermeiro da atenção básica para o reconhecimento e enfrentamento das necessidades em saúde das famílias. 


\section{BASE TEÓRICA E PRESSUPOSTOS CONCEITUAIS}

Com o propósito de compreender o processo de reconhecimento e enfrentamento das necessidades em saúde das famílias pelo enfermeiro, buscou-se construir um referencial que permitisse compreender a realidade encontrada nas suas diferentes dimensões, como propõe a base filosófica adotada neste estudo, Materialismo Histórico e Dialético (MHD). Portanto, os temas explorados a seguir são: necessidades; epidemiologia - a construção do objeto para a intervenção em saúde coletiva; serviços de saúde - planejamento e programação na definição da intervenção; participação popular na definição de diretrizes nas Políticas Públicas de saúde e competências.

\subsection{NECESSIDADES}

Marx (1985) afirma que as necessidades humanas são satisfeitas por meio das mercadorias e que estas são antes de tudo objetos externos ao ser humano, um objeto que é de consumo, independente da sua natureza. O consumo pode ser direto ou indireto, mas é a utilidade do objeto que definirá o seu valor de uso. Valor de uso que está relacionado às propriedades no corpo da mercadoria e ao trabalho humano aplicado na sua produção. Assim, a relação de troca de mercadorias se estabelece nas sociedades em tempos históricos de acordo com o modo de produção.

Heller (1986) conceitua necessidades com base nas análises que realizou sobre as obras de Marx e, assim, divide-as em dois grandes campos: necessidades existenciais - as que se referem à mera sustentação da vida humana, ontologicamente primária, estão baseadas nos instintos - e necessidades sociais - desejo, aspiração ou intenção dirigida a certo objeto e que motiva a ação. Considera que todos são produtos e atos sociais. Ao discutir as características das necessidades, a autora afirma que estas podem ser compreendidas em: 
- Necessidades existenciais, naturais ou necessárias - aquelas que são para atender à manutenção da própria vida humana, para as necessidades vitais, para a autoconservação do ser humano. Sem a satisfação destas o indivíduo não pode viver. Estão relacionadas à vida normal de pessoas que pertencem a uma determinada classe social em um determinado tempo em uma determinada sociedade, são geradas mediante a produção material e, nesse sentido, são crescentes de acordo com a produção material de uma sociedade em determinado tempo. Em uma sociedade capitalista a distribuição dos bens para atendê-las está relacionada à inserção do indivíduo na produção.

- Necessidades radicais - são necessidades necessárias compreendidas como aquelas que precisam ser satisfeitas para que os membros de uma sociedade ou classe social, em um determinado tempo histórico, tenham a sensação ou convicção de que suas vidas são 'normais';

- Necessidades livres - são necessidades necessárias que se contrapõem às necessidades materiais, são espirituais, morais. Não estão relacionadas à reprodução social, mas à liberdade do indivíduo;

- Necessidades sociais ou produzidas socialmente - diferem das necessidades naturais, pois são produzidas pela relação do indivíduo com a sociedade, no seu processo de socialização, no qual se destaca o processo de produção-consumo. São necessidades entendidas como totalidade, média ou tendência que determinam o desenvolvimento das necessidades individuais ou particulares. Estão acima das necessidades individuais ou pessoais, pois são gerais e mais elevadas que estas, assim as necessidades pessoais devem ser a elas subordinadas. As necessidades sociais ou produzidas socialmente são definidas por classes hegemônicas para que as outras classes sociais submetam as suas necessidades particulares às que foram definidas como sociais. A autora explica ainda que as necessidades das diferentes 
classes passam a ser definidas por seus representantes. Logo, nesse caso, se compreende que as necessidades que serão 'reconhecidas' ou 'não reconhecidas' socialmente negam as necessidades próprias e efetivas de cada indivíduo.

- Necessidades de luxo, refinadas ou de ostentação - são necessidades relacionadas à ostentação de bens de acordo com a acumulação de riqueza, expressas em determinadas classes sociais. São aquelas que estão fora da capacidade de consumo da classe operária, e assim não fazem parte dos costumes dessa classe. Segundo a lógica econômica, essas necessidades são necessárias para uma minoria de poder aquisitivo mais elevado. As necessidades de luxo podem ser convertidas em necessidades necessárias sem mudanças no seu aspecto qualitativo, ao contrário, este fenômeno se daria como consequência de crescente produtividade, assim como por mudanças na estrutura social.

[...] En los Grundisse Marx habla de la 'capacidad de consumo' como fuente de las necesidades de la sociedad capitalista y distingue las necesidades 'producidas por la sociedad' de las necesidades 'naturales'. Respecto al capitalismo escribe: 'En su aspiración incesante por la forma universal de la riqueza, el capital, empero, impulsa al trabajo más allá de los límites de su necesidad natural y crea así los elementos materiales para el desarrollo de la rica individualidad, tan multilateral en su producción como en su consumo, y cuyo trabajo, por ende tampoco se presenta ya como trabajo, sino como desarrollo pleno de la actividad misma, en la cual ha desaparecido la necesidad natural en su forma directa, porque una necesidad producida históricamente ha sustituido a la natural' y más adelante: 'El 'lujo' es la antítesis de lo 'naturalmente necesario'. Necesidades imprescindibles son las del individuo reducido él mismo a un sujeto natural. El desarrollo de la industria suprime esa necesidad natural, así como aquel lujo (en la sociedad burguesa, por cierto, sólo 'contradictoriamente', puesto que ella misma sólo contrapone al lujo determinada medida social como la necesaria)'. En el Capital la categoría de 'necesidades naturales' aparece a través de la determinación del valor de la fuerza de trabajo: 'Las necesidades naturales, el alimento, el vestido, la calefacción, la vivienda, etc., varían con arreglo a las condiciones del clima y a las demás condiciones naturales de cada país. Además, 'el volumen de las llamadas necesidades naturales', así como el modo de satisfacerlas, son de suyo un 'producto histórico' que depende, por lo tanto, en gran parte, del nivel de cultura de un país y, sobre todo, entre otras cosas, de las condiciones, los hábitos y las exigencias con que haya formado la clase de los obreros libres. A diferencia de las otras mercancías, la valoración de la fuerza de trabajo encierra, pues, un elemento histórico 
moral'. Finalmente el valor de la fuerza de trabajo aparece definido del siguiente modo: 'El valor de la fuerza de trabajo se determina por el valor de los medios de vida consuetudinariamente necesarios para el sustento del obrero medio'. [...] (Heller, 1986, p.29-30, grifos da autora).

A construção e geração da necessidade se dão a partir da ordem individual ou micro (gênese) e a sua reprodução ocorre na ordem social ou macro (reprodução social). No cotidiano dos indivíduos e suas famílias encontram-se os processos básicos que estão relacionados aos fenótipos, necessidades fisiológicas e psicológicas, essas são atendidas de acordo com as possibilidades e os obstáculos que se têm para tal, em um espaço que é histórico e socialmente construído. Logo, é uma construção que ocorre em

[...] espaços sociais concretos, marcados nos condicionamentos econômicos, culturais e políticos (modos de vida típicos) que, em cada classe social e de acordo com as relações étnicas e de gênero que as caracterizam [...] (Samaja, 1993 apud Breilh, 2006, p.171).

As respostas às necessidades individuais estão diretamente relacionadas às formas de produção e circulação de bens que são determinadas pela estrutura coletiva. A satisfação das necessidades é por um movimento de opções individuais em um movimento determinante que é coletivo, por meio da produção de bens e da distribuição àqueles aos quais o Estado tem a responsabilidade de repartir. Para Boltivinik (1994) apud Breilh (2006), esse movimento, produção e distribuição de bens, que procura atender às necessidades dos indivíduos é estabelecido pela lógica dos interesses das classes hegemônicas. São as classes hegemônicas que, de acordo com suas conveniências, definem os elementos de satisfação das necessidades das outras classes, ou seja, daquelas que estão submetidas aos desejos dos que detêm o poder. Nesse mesmo contexto, refere o autor, também estão os valores que serão atribuídos aos serviços de saúde, sejam eles públicos ou privados.

Para Heller (1986), quanto mais se emprega força de trabalho humano na produção de um objeto, independente da natureza deste, mais este objeto se aproxima de um artigo de luxo, de ostentação. Neste caso, ele que só 
poderá ser adquirido por classes socais com maior poder aquisitivo. Para Mendes-Gonçalves (1992) as necessidades sociais representam as necessidades de produção e reprodução do modo de produção, assim deixam de ser naturais, pois estão em uma sociedade que tem a distribuição e o consumo dos processos de trabalho desiguais.

O valor de uso da mercadoria está relacionado à possibilidade de atender às necessidades humanas, seja ela de qualquer classe social. Assim, independente de qual seja a necessidade (fome ou um artigo de luxo) a sua satisfação representa condição sine qua non para o uso da mercadoria. Logo, não há valor de troca para a mercadoria se não houver valor de uso. Porém, pode haver valor de uso sem o valor de troca, desde que este seja para satisfazer a uma necessidade do indivíduo. Nessa perspectiva, o trabalhador que vende sua força de trabalho para o capitalista e recebe dele o valor referente (salário) terá as suas necessidades definidas na relação do valor que recebe e que possibilita a sua reprodução social, pois, na venda de sua força de trabalho, já estão definidos quais são os meios de que necessita para se reproduzir socialmente (Heller, 1986).

[...] Como sabemos, por definición el valor de uso satisface necesidades: las necesidades de la producción de plusvalía y por consiguiente de valorización del capital. (Si la fuerza de trabajo no produjese plusvalía y el capitalista no comprase de trabajo el sistema capitalista dejaría de existir) [...] y forzosamente tiene que ser así, en un régimen de producción en que el obrero existe para las necesidades de valoración de los valores creados, en vez de existir la riqueza material para las necesidades del desarrollo del obrero (Heller, 1986, p.22, grifo da autora).

Scherer (1997, p.159) analisa a Teoria das necessidades humanas defendida por Doyal e Gough (1991) e afirma que para os autores "[...] as necessidades sociais não podem ser reduzidas a desejos ou simples expectativas [...]", porque para esses autores as sociedades industriais têm, no seu processo de produção e consumo, uma significativa complexidade de espaços que se inter-relacionam e determinam a produção de necessidades nas famílias e nos pequenos grupos. Ao mesmo tempo este fenômeno, a complexidade de espaços que inter-relacionam, apresenta aos indivíduos "[...] o mercado como o mecanismo para a satisfação das necessidades 
humanas; ou relacionada aos serviços públicos do Estado de Bem-Estar [...]". Contrapondo-se a esta lógica do mercado, os autores defendem que as sociedades devem ter objetivos comprometidos com seus cidadãos e que deveriam considerar o atendimento às necessidades como um pré-requisito à autonomia dos indivíduos para que eles tenham vidas livres emancipadas, não atreladas ou definidas por um mercado utilitarista definidor de desejos e preferências.

[...] há um confronto entre duas 'grandes correntes' a propósito do tema da definição da necessidade: a) a necessidade humana como um valor relativo, que depende de opções individuais e das possibilidades de cada pessoa e sua família para adquiri-las no mercado (corrente liberal); b) a necessidade como um processo determinante da vida, cuja realização constitui, por isso mesmo, um direito humano inalienável, ao qual se deve aceder através de uma distribuição eqüitativa e segura por parte de todos os membros de uma sociedade, a qual deve construir-se solidariamente em prol do máximo bem comum (corrente solidária). [...] (Breilh, 2006, p.169-70).

Reconhecer os indivíduos, usuários dos serviços de saúde, como portadores de necessidades é reconhecer o mundo das necessidades, assim como suas diversidades de representações e constituições nesses sujeitos. Neste caso, as representações podem ser na maneira como este indivíduo consagra a saúde, podendo compreendê-la como um "[...] direito social a ser satisfeito pelo poder público [...]" (Merhy, 2003, p.78).

A escuta que é realizada nos serviços de saúde pode levar a um efetivo atendimento e intervenção sobre as necessidades expressas pelos usuários. Essas intervenções podem ser para promoção da saúde, proteção específica a um adoecimento ou mesmo para a recuperação do quadro apresentado por um sujeito de algum agravo que desenvolveu. Para Merhy (2003, p.91),

[...] os usuários procuram, ao consumir produtos do trabalho em saúde, pelo menos serem acolhidos nesse processo, a ponto de que na dinâmica do mesmo haja um momento em que se possa 'escutá-los' nas suas manifestações-necessidades [...]. 
Chiesa (1999) afirma que as necessidades em saúde serão percebidas pelos indivíduos, usuários de serviços, segundo os momentos históricos e contextos sociais em que vivem. Esta percepção será definidora dos projetos e dos modelos de intervenção em saúde. O modelo de intervenção em saúde é definido por Mendes (1999) como a maneira que a sociedade, em determinado tempo histórico, tem de organizar seus conhecimentos para intervir no processo saúde-doença a fim de promover qualidade de vida, para o indivíduo ou para a população.

Bertolozzi e Fracolli $(2004$, p.16) afirmam que "[...] os modelos de assistência não estão isentos dos interesses e da vontade dos sujeitos sociais e não são universais [...]". Logo, a exclusão destes interesses e vontades torna a intervenção em saúde estéril às questões vividas pelos sujeitos envolvidos. Segundo as autoras, no desenvolvimento da assistência à saúde devem ser consideradas as intermediações entre os aspectos técnicos e políticos da ação. Para a descrição da realidade observada deve-se ter a participação dos técnicos e usuários no sentido de identificar a sua determinação e, assim, definir quais ações em saúde serão desenvolvidas na intervenção. Portanto, as práticas sanitárias deverão ter combinações tecnológicas distintas para enfrentar as questões de saúde em um determinado território e, logo, organizar o processo de trabalho em saúde.

Laurell (1983), Egry (1996) e Mendes-Gonçalves (1992) afirmam que o processo saúde-doença é determinado pelo modo como o ser humano se relaciona com a natureza a qual se dá por sua inserção no trabalho, sendo este determinado pelo desenvolvimento das forças produtivas e das relações sociais de produção, segundo o modelo econômico vigente naquela sociedade, num determinado tempo histórico. Para Egry (1996), Bertolozzi e Fracolli (2004) e Breilh (2006), a determinação do processo saúde-doença está relacionada a três dimensões: estrutural ou geral; particular e singular. Nesse sentido, afirmam que os desgastes serão representados no coletivo pelas diferentes expressões da epidemiologia e percebidos no corpo do indivíduo pelas expressões de desgastes por meio de queixas, sinais e sintomas. 
A saúde não é primordialmente 'individual-subjetiva-contingente', nem tampouco é primordialmente 'coletiva-objetiva-determinada'; ela é, sempre e simultaneamente, o movimento de gênese e reprodução possibilitado pelo concurso de processos individuais e coletivos, que se articulam e se determinam mutuamente. Ela tampouco é primeiro individual e depois coletiva, como produto da combinação de realidades individuais. Em suma, o olhar dialético nos permite ver que essa discussão não tem sentido, porque livre arbítrio e determinação coletiva não são termos excludentes, mas interdependentes (Breilh, 2006, p.45).

A intervenção resolutiva em saúde tem que estabelecer critérios e ferramentas para nortear e estruturar a identificação das necessidades em saúde. Nessa perspectiva, Cowley e Houston (2004) destacam que o contato entre os profissionais e usuários para um levantamento real das necessidades em saúde deve ser fundamentado em referenciais que permitam o desenvolvimento de ações com critérios e, para tal, as ferramentas devem ser preestabelecidas para identificar famílias e grupos que necessitam de suporte dos profissionais. Para as autoras, a intervenção em saúde por meio da visita domiciliária é uma possibilidade para se identificar as necessidades em saúde dos usuários. Destacam que esta atividade possibilita o "encontro" entre o conhecimento científico e a realidade social.

Em estudo para compreender a mudança no discurso dos visitadores na avaliação de necessidades em saúde nas visitas domiciliárias, as pesquisadoras Cowley, Mitcheson e Houston (2004) perceberam que, ao invés de utilizar os instrumentos para identificar as necessidades dos usuários, os profissionais seguiam o enfoque da epidemiologia associado a fatores de risco e avaliação de riscos previamente definidos. Para as autoras, os usuários seguiam o mesmo enfoque atendendo ao que o serviço esperava deles. Logo, a visita domiciliária perdia seu potencial para identificar indivíduos vulneráveis, mas atendia aos propósitos estabelecidos pela organização dos serviços. Reconheceram este fenômeno como a medicalização da visita domiciliária.

Segundo Stotz (1991), reduzir as necessidades em saúde do indivíduo ao que é expresso biologicamente pelo desgaste no corpo tem sido a prática do sistema institucionalizado de saúde. Dessa forma, o sistema referenda a não conscientização dos sujeitos sobre os processos de desgastes, determinantes do processo saúde-doença, a que estão submetidos. Isso ocorre pelo papel 
desenvolvido pelo Estado em normatizar para intervir em saúde no sentido de manter as forças de trabalho mediante a avaliação dos riscos para adoecimentos

Na organização das intervenções a serem desenvolvidas pelos serviços, o autor acima citado aponta que as necessidades são tecnicamente definidas por gestores e profissionais do setor e por meio dessas definições se conformarão às demandas atendidas nos serviços, pois aí se encontra excluída parte das necessidades expressas pelos indivíduos, já que são deixadas fora do atendimento aquelas que não são consideradas possíveis de intervenção nos parâmetros previamente estabelecidos e desejados. Assim, as necessidades em saúde que serão satisfeitas nos serviços estão relacionadas aos padrões previamente estabelecidos que valorizam as demandas.

Para a leitura do processo saúde-doença, das vulnerabilidades ${ }^{2}$ e das necessidades em saúde, na perspectiva coletiva, Nakamura et al. (2009) defendem o uso de instrumento previamente elaborado que consiga coletar dados permitam a análise da realidade para instrumentalizar as intervenções a serem desenvolvidas pelos profissionais de saúde em suas práticas sanitárias transformadoras. O processo discutido pelas autoras se inicia na graduação de Enfermagem com o objetivo de preparar os futuros profissionais com base teórica da Saúde Coletiva.

Chaves (2000, p.81) afirma que "[...] a prática sanitária desenvolvida nos serviços de saúde tem sido ineficaz aos problemas apresentados [...]". Nesta relação entre serviço e usuários, ocorrem o descrédito dos serviços de saúde e as resistências dos usuários para aceitarem intervenção que poderá promover a saúde, prevenir e curar doenças. Assim, os usuários, primeiramente, esgotam medidas que não foram institucionalizadas e posteriormente seguem as medidas orientadas, pois possuem dúvidas por não terem sido "[...] convencidos pelos técnicos das razões científicas para as intervenções propostas e realizadas institucionalmente [...]".

\footnotetext{
2 Nakamura et al. (2009) referendam o conceito de vulnerabilidade social como sendo uma dimensão tanto dos processos de exclusão, discriminação ou enfraquecimento dos grupos sociais, quanto da capacidade de enfrentamento dessas condições. Esta não é restrita a suscetibilidades individuais, mas ao plano coletivo, histórica e socialmente determinado.
} 
Mendes-Gonçalves (1992) ao discutir a intervenção em saúde analisa que o nascimento da medicina social esteve, desde o início, ligado ao projeto de transformação do desviante para atender ao interesse de determinada classe social e organizar as outras classes para atender aos interesses daqueles que detinham o poder. O conceito de classe social, para o autor, apresenta-se além das relações econômicas e de poder, definindo a realidade e o direito à cidadania. Neste caso, reflete-se sobre a proposta de intervir segundo as necessidades percebidas na realidade, pois existe significativa distância entre a necessidade em saúde, expressa individual ou coletivamente, e a implementação de ações para o seu atendimento. Este fenômeno é uma das questões que o Sistema Único de Saúde tenta superar quando define como princípios a universalidade, equidade, integralidade e busca organizar os serviços por meio da descentralização, regionalização, hierarquização das ações com a participação social na definição das Políticas Públicas de saúde. Nessa perspectiva, diversas contradições podem ser percebidas nas práticas sanitárias preconizadas pelo SUS por meio dos programas e protocolos adotados, uma vez que aumentam coberturas e mantêm o enfoque nas doenças, ficando distantes de considerar os usuários como indivíduos portadores de necessidades e com possibilidades de discutirem o processo de assistência à saúde. Assim, os usuários se submetem ao que Ihes é oferecido, pois não têm como buscar atendimento para as suas necessidades.

\footnotetext{
A hegemonia requerida pela ordem social dominante também se constrói e se reproduz na saúde, e se forjam ilusões que procuram bloquear a coletivização da alma popular e visam à dissolução de seus recursos de organização coletiva. Procura-se impedir que os integrantes das coletividades subalternas se reconheçam como parte de uma classe dominada, ou como um povo (étnico) dominado ou um gênero dominado; busca-se criar barreiras materiais e obstáculos epistemológicos para que eles não cheguem a conclusões emancipadoras e compreendam que, sem destruir a estrutura de poder, é ilusório chegar a uma reivindicação, a não ser por um caminho individual; e assim, na saúde como em outros campos, forja-se a quimera da libertação por autogestão pessoal e pela simples autoconfiança pessoal, enquanto se tecem as sutilezas da privatização e da transformação da saúde em um negócio, por parte dos proprietários dos grandes monopólios (Breilh, 2006, p.48).
} 
É a contradição em si do sistema público de saúde que busca a mudança da prática sanitária e referenda nos seus serviços uma prática local conformada a padrões preestabelecidos e técnicas de intervenção que são universais. Toma o "coletivo" como o "individual" e impõe práticas sanitárias que não consideram as necessidades percebidas. Assim, referenda uma prática sanitária com acentuada divisão social do trabalho, sem discutir qual é a relação entre o sujeito e o objeto desta prática. A compreensão de que o indivíduo é responsável por suas escolhas e condições de vida é encontrada em muitos programas de saúde, e acredita-se que essa é uma das estratégias para se negar a construção de um projeto coletivo de transformação social para de fato modificar a determinação da realidade local.

A intervenção na determinação da realidade atingiria os interesses das classes dominantes. Para que o indivíduo possa realmente fazer suas escolhas seria necessário um longo processo de conscientização dos cidadãos e consequentemente de transformação da sociedade, na qual se garantiria a igualdade, autonomia, liberdade e acesso a bens necessários para a vida com dignidade para todos.

\subsection{EPIDEMIOLOGIA: A CONSTRUÇÃO DO OBJETO PARA INTERVENÇÃO EM SAÚDE COLETIVA}

Ao refletir sobre o tema busca-se compreender historicamente a construção do atual objeto da epidemiologia para a saúde coletiva, reflete-se sobre a historicidade dos conceitos de causalidade do adoecimento e, as teorias que marcaram as explicações dos fenômenos saúde e doença, desde as práticas mágico-religiosas até a racionalidade científica moderna. E ao final, aponta-se a contribuição da teoria da determinação social do processo saúde-doença para a intervenção em saúde coletiva. 
[...] as concepções sobre a saúde e a doença são limitadas pelo desenvolvimento teórico-conceitual da ciência e, sobretudo, por condicionantes ideológicos que tornam determinadas opções conceituais mais legitimas e mais potentes que outras. Ancoram-se em marcos teóricos e filosóficos distintos e expressam-se modelos de causalidade que, por sua vez, desdobram-se em formas de registro, mensuração, análise, interpretação e intervenção correspondentes. Retratam a diversidade conceitual e metodológica resultante das transformações dos marcos de inferência causal ao longo da história da constituição desses saberes - das crenças mágico-religiosas, passando pelo empirismo racional, até a ciência moderna (Oliveira; Egry, 2000, p.12).

Portanto, ao discutir historicidade do conhecimento de causa das doenças e da epidemiologia, buscou-se explorar, brevemente, o contexto macroestrutural, assim como relacionar os conhecimentos de outras ciências que foram influentes na construção epistemológica.

\subsubsection{As concepções teóricas na epidemiologia: do mágico-religioso à racionalidade científica moderna}

Historicamente compreender a causa da doença foi condição essencial para se organizar a intervenção em saúde no sentido de atender às necessidades em saúde das populações. Rosen (1994) reconhece que, desde os povos mais antigos, na busca de explicações sobre os adoecimentos surgiram diferentes correntes e teorias explicativas que foram orientadoras no enfrentamento dos adoecimentos. A partir do século XVII se identifica a busca de saberes teóricos para dar conta desta questão. Barata (2005) afirma que eram discursos individuais que buscavam explicação sobre o adoecimento coletivo.

A epidemiologia como ciência surgiu posteriormente, no início do século XIX, com o desenvolvimento de estudos sobre padrões populacionais para compreender o processo de adoecimento e de saúde. Rosen (1980) destaca os estudos de Chadwick (estudo sobre a diminuição absoluta da população em Londres) e de J. Snow (sobre a cadeia de transmissão da Cólera em Londres, 1848). Como esses, outros estudos da época procuravam explicações para o grande número de pessoas moradoras dos centros 
urbanos que adoeciam em larga escala e muitas vezes eram levadas à morte. Barata (2005, p.7) afirma que vários estudos desenvolvidos nessa época poderiam ser compreendidos como estudos de epidemiologia social, pois "[...] buscavam explicar os padrões de adoecimento através dos vínculos entre a saúde e a sociedade [...]."

Nesses estudos epidemiológicos os objetivos eram compreender as tendências, a distribuição dos casos, as características dos indivíduos acometidos, a espacialização e se havia ocorrência do adoecimento em outros períodos. Os dados eram basicamente para fornecer subsídios para ações em saúde pública. As condições de vida dos centros urbanos eram preocupantes, pois precisavam ser definidas intervenções sanitárias eficazes para garantir condições mínimas de vida e queda nos números de doentes e mortos. Nos centros urbanos os trabalhadores e suas famílias passavam fome e viviam em más condições de vida. Cresceram os movimentos sociais que reivindicavam mudanças nas péssimas condições de vida, assim como também melhorias nas condições e relações de trabalho (Fachini, 1994).

Engels, por meio do seu estudo intitulado "As Condições da Classe Trabalhadora na Inglaterra em 1844", caracterizou que diferenças na inserção dos indivíduos no processo de produção determinavam as condições materiais de suas vidas e, assim, este processo era determinante para o perfil de adoecimento e alta mortalidade entre os pobres. Demonstrou também que os diferentes grupos sociais, segundo o processo produção, tinham o perfil de adoecimento diferenciado, ou seja, o trabalhador tinha a situação de adoecimento mais grave do que a classe social mais abastada, detentora dos meios de produção (Oliveira; Egry, 2000). E que, dada à precariedade nas condições de vida da classe operária da Inglaterra, as crianças sofriam privações que teriam consequências na sua saúde quando adulto (Barata, 2005).

A preocupação com a inserção e manutenção do indivíduo como força produtiva na produção industrial, na Inglaterra, foi relacionada ao desenvolvimento da saúde pública por Rosen (1980). Ao Estado caberia manter o maior número possível de indivíduos saudáveis, entendendo-os como um fator no processo de produção. Assim, no início do processo de industrialização ocorreram as primeiras tentativas de aplicar métodos estatísticos, registros sistemáticos e 
detalhados dos dados de natalidade, mortalidade, morbidade, modo de vida, ambientes de moradia e trabalho. Após análise dos dados levantados, as medidas de intervenção eram recomendadas. Conforme Barata (2005, p.7), para que as intervenções em saúde tivessem a eficácia desejada eram consideradas "[...] as tendências de distribuição dos casos, caracterização dos indivíduos acometidos, espacialização e ocorrência em períodos anteriores [...]." A contradição apontada por Ayres (1995a) para a epidemiologia desenvolvida nesse período foi o uso das técnicas estatísticas no sentido de explicar a causa das doenças, assim como os fatores responsáveis pela condição física observada nos indivíduos. Logo, as explicações epidemiológicas não buscavam o reconhecimento do motivo pelo qual este fenômeno ocorria.

A compreensão de que os adoecimentos teriam explicações nas relações apresentadas pela epidemiologia e pelas ciências sociais passou a vigorar e foi aceita até as primeiras décadas do século XX (Barata, 2005). Até então, século XVIII, o pensamento dominante entre as correntes explicativas sobre o adoecimento era a teoria miasmática, na qual o ar era o fator patógeno. A compreensão sobre a patogenicidade do ar era pela ocorrência da ação mecânica do ar sobre o corpo do indivíduo e este contato produziria os adoecimentos, que eram definidos segundo as próprias qualidades do ar frio, quente, úmido e seco (Foucault, 1982; Rosen, 1994).

Para Rosen (1994), havia três posições teóricas anteriores ao pensamento da epidemiologia, sendo a primeira corrente a miasmática, a segunda a do contágio e a terceira a do contagionismo limitado ou contingente. Esta última, a mais abrangente, era aceita por representar a conciliação das abordagens miasmáticas e contagionistas.

Na segunda metade do século XIX a epidemiologia já é uma disciplina em processo de consolidação e verifica-se uma intensa disputa entre os modelos causais contagionistas e sociais. Pasteur em uma sessão da Academia de Medicina na França (1878) anuncia a "teoria microbiana" das doenças, antes mesmo do isolamento de algum micro-organismo. E em contraposição Virchow argumenta que os problemas sociais são responsáveis pelos problemas de saúde e que os momentos dos surgimentos das grandes epidemias são os de mudança nos modos de produção. Grotjahn em A Patologia Social discute as relações entre as condições sociais e a doença, fundamentando as relações dialéticas entre doença e condição social. W. Farr (1864), um dos mais importantes defensores da 
teoria miasmática, estuda a mortalidade dos mineiros ingleses e mostra sua estreita relação com as condições de trabalho e vida. Representando a teoria contagionista, Koch (1882) defende que toda doença tem uma única causa e toda causa determina uma única doença. Os importantes achados da microbiologia consolidam a teoria dos germes e estabelecem a hegemonia unicausal na epidemiologia e na medicina (Fachini, 1994, p.38, grifo do autor).

A corrente microbiana emergiu no século XIX após as descobertas bacteriológicas. Essas descobertas referendam a questão da causalidade dos adoecimentos que passa a ser simplificada à compreensão de que para cada doença há um agente etiológico identificado. As intervenções em saúde ficaram restritas ao combate desta única causa - o agente etiológico, o qual deve ser identificado e combatido com produtos químicos e a prevenção do adoecimento por meio das vacinas (Barata, 1985).

A teoria da unicausalidade seguiu predominando o desenvolvimento do conhecimento e da prática médica e a consequência observada foi que houve o deslocamento da concepção social do adoecimento e da saúde, porém sem fazer com que esta desaparecesse (Fachini, 1994). O predomínio das doenças infecto-contagiosas no século XIX favoreceu o avanço de teorias baseadas na compreensão unicausal e os modelos de intervenção buscavam o controle destes adoecimentos por meio da identificação do agente etiológico e da cadeia de transmissão. Assim, as ações da epidemiologia foram direcionadas para o processo de transmissão e controle das doenças prevalentes: varíola, malária, febre amarela, entre outras. Esse modelo permitiu, posteriormente, a elaboração da rede de causalidade (Barata, 2005).

Para Barata (1985), as descobertas da bacteriologia foram importantes para a medicina, uma vez que a libertou dos complexos determinantes econômicos, sociais e políticos, tornando possível o desenvolvimento de pesquisas científicas na área. $O$ esgotamento desse modelo veio com a mudança do perfil das doenças prevalentes, ou seja, diminuição dos índices das doenças infecto-contagiosas e aumento dos índices das doenças crônicodegenerativas no início do século XX. Portanto, a teoria da multicausalidade, com suas diferentes abordagens e que passou a explicar os adoecimentos por meio de uma rede de relações causais, toma o espaço esgotado pela explicação unicausal. 
Porém, reconhece-se que na abordagem multicausal as explicações são tomadas de maneira simplificada, a-histórica e centrada no biologicismo. $\mathrm{Na}$ abordagem multicausal se identificam os fatores e estes passam a ser compreendidos como partes de um conjunto mais amplo de causas. Posteriormente, toma-se, na rede de fatores, aquele que seja considerado o de maior peso e sobre ele se efetua a intervenção. Logo, evidencia-se que a intervenção denuncia a redução da multicausalidade para a unicausalidade. Cabe destacar que neste referencial a compreensão sobre a causalidade do adoecimento deixa de ser somente o micro-organismo e passa a ser uma rede ou um conjunto de fatores. Portanto, o avanço é superar a abordagem restritiva da bacteriologia nas questões relacionadas à saúde e doença. Porém, na análise para propor a intervenção, os fatores são postos no mesmo plano de abordagem, sem hierarquia e assim se seleciona o mais significativo e se propõe agir sobre ele. Logo, a simplificação exagerada torna o modelo de causação mecânico (Fachini, 1994; Barata, 1985, 2005).

Facchini (1994) reconhece que algumas questões devem ser ressaltadas nos modelos explicativos até agora apresentados: a epidemiologia, ao centrar esforços no sentido de analisar a ocorrência das doenças, deixou de se preocupar com a sua determinação, logo houve o estreitamento do seu campo; a simplificação do modelo multicausal tomou como conjunto de causas aquilo que estivesse mais aparente negando a articulação e hierarquização de elementos que também atuavam para a produção do fenômeno; o social foi biologizado ou compreendido como algo externo ao ser humano, e, alguns estudos tentaram avançar no sentido de retomar a determinação social com inclusão de variáveis que atendessem à proposta, porém tomaram estas variáveis como homogêneas, sem hierarquizá-las.

Os conhecimentos descritos acima foram influentes na construção de modelos científicos necessários para a intervenção epidemiológica. Barata $(1985,2005)$ reconhece essa contribuição, mas afirma que, ao mesmo tempo em que o avanço foi comprovado, também ficou demonstrado que os modelos explicativos e de intervenção atenderam ao modelo econômico, pois as doenças passaram a ser compreendidas como alterações de produção biológica e individual derivadas da relação estabelecida entre o indivíduo, o agente e o 
meio ambiente. Portanto, para modificar a realidade indesejada buscava-se atuar sobre um dos fatores identificados, o de maior peso, sem ser necessário modificar a organização social.

Ayres (1997) resgata a historicidade do conceito de risco e demonstra que a proposta teórica teve início com Pettenkofer no Instituto de Higiene de Munique no século XIX. Para o autor, a preocupação com as altas taxas mortalidade e morbidade da população de Munique levou o estudioso a desenvolver conhecimentos que permitissem identificar as diferenças entre duas populações da época - Londres, Inglaterra e Munique, Alemanha. A justificativa para os estudos se dava pelo ao alto custo do adoecimento e morte na população trabalhadora para a sociedade que estava em processo de industrialização, no que Londres já havia superado ao adotar medidas sanitárias que diminuíram tais índices. Assim, ao desenvolver os estudos, Pettenkofer associou várias áreas de conhecimentos, principalmente biológicas, estatísticas, bacteriologia e noções sobre o meio ambiente que, articulados, indicavam características individuais, condições sanitárias e probabilidades de se desenvolver tal adoecimento e a partir deste chegar ao óbito. Era o nascimento de um novo pensamento na área da saúde - a probabilidade individual de desenvolver algum agravo seria revertida se o indivíduo adotasse medidas ou escolhas que modificassem tal destino, sem que houvesse a necessidade de se discutir as condições de vida na sociedade.

Com essas proposições teóricas e respaldos para novos estudos, outros pensadores passaram também a adotar a mesma linha científica. Ayres (1997) demonstra que escolas de saúde pública de outros países seguiram os pensamentos do então pioneiro Pettenkofer, entre elas cita: Escola de Higiene e Saúde Pública dos EUA (Baltimore, Havard, 1921); London School of Hygiene and Tropical Medicine (Londres, 1924); escola de Higiene da Universidade de Toronto (Canadá, 1924); Peking Union Medical College (China, 1919) e Instituto de Higiene de São Paulo (Brasil, 1924). Ademais, o autor aponta a influência do pensamento da Escola de Higiene e Saúde Pública dos EUA na formação para a saúde pública dos respectivos países e, com base nele, foram desenvolvidas as intervenções em saúde nas suas populações no século XX. 
No quadro de referência do paradigma de risco, todos os processos a que se alude com designação de riscos seriam apenas 'provavelmente' destrutivos; sua nocividade seria apenas contingente. $\mathrm{E}$ com isso se acaba por admitir que, numa sociedade como a nossa, na qual a desigualdade se reproduz estruturalmente, e na qual existe uma subjunção do humano ao produtivo e ao mercantil, haveria margem para a plena reprodução da saúde - ou, pelo menos, para se ter esperança dessa possibilidade -, já que os riscos nela atuantes seriam apenas prováveis, ou seja, seriam variáveis que poderíamos dominar com o simples controle da variação de cada uma delas em níveis toleráveis. O paradigma de risco, desse modo, enquadra-nos num mundo atomizado, no qual os fatores de risco são variáveis, e sua variação é contingente; nenhum deles faria parte de algo permanente nem teria na permanência uma de suas qualidades, pois nesse caso, deixaria de ser um 'risco' para se converter num feito destrutivo. Em suma, nesses tipos de concepções, o contingente substitui o determinado, em vez de se considerar o contingente e o regular como pólos de um movimento dialético (Breilh, 2006, p.200).

Os dados epidemiológicos analisados por meio de números absolutos e relativos, a matematização da epidemiologia ocorrida nas décadas de1960 e 1970, alimentaram ideologicamente o modelo racional que serviu de base para construção de um modelo individualizante, baseado em casos clínicos que posteriormente eram agrupados para se ter a percepção do todo, porém a soma das partes não traduzia a dimensão social negada anteriormente. Para Barata (2005, p.10), os "[...] movimentos de enfraquecimento da relação entre a epidemiologia e as ciências sociais acabam por determinar o ocultamento do caráter coletivo e social da epidemiologia [...]" o que a autora considera definidor da substituição da perspectiva populacional pela perspectiva individual nas investigações epidemiológicas. Para Spink apud Luiz e Cohn (2006), no campo da saúde a concepção de risco supõe que as pessoas, ao tomarem conhecimento sobre seu comportamento que o leva a adquirir determinado adoecimento, podem se autogerenciar e modificá-lo para atingir plena saúde.

Luiz e Cohn (2006, p.2340) afirmam que a noção de risco está relacionada às transformações induzidas e produzidas pelo processo de modernização das sociedades que tem como uma de suas características:

[...] um processo de substituição das biografias marcadas pela inserção em classe por biografias reflexivas, inscritas a partir de decisões individuais, implicando uma diversidade de estilos de vida. Contudo as desigualdades se aprofundam; a estrutura da família se altera [...] as relações de gênero se modificam; a sexualidade se redefine [...] 
Os autores afirmam que a noção de risco surge quando o futuro passa a ser previsível e passível de ser controlado. Outra característica que apontam está relacionada às mudanças na produção de conhecimento. Nesta o risco passou a ser analisados por meio de cálculos de riscos, percepções dos riscos pelo público, gestão dos riscos e a comunicação pública dos riscos relacionados a um evento adverso. Referem que este é o marco do fim da sociedade disciplinar, modernidade clássica, e o princípio da sociedade do risco. E para cada risco identificado "[...] criam-se agências governamentais reguladoras com a contratação de especialistas e a formação de comissões técnicas responsáveis pela avaliação dos riscos [...]" (Luiz; Cohn, 2006, p.2340). O controle passa a ser por redes interligadas de informação, por "sistemas de controle transdisciplinares, transdepartamentais, transnacionais". A ética passa a ser dialogada e não mais prescritiva. A informação é institucionalizada por meio de várias tecnologias da informação que the garante capilaridade, nesse caso, implicando novas formas de vigilância "[...] traduzidas no auto-controle do estilo de vida e no monitoramento constante do indivíduo [...]" (p.2340).

A concepção de risco na saúde na literatura, segundo Hayes apud Luiz e Cohn (2006), apresenta três vertentes: risco individual (health risk appraisal - HRA) é representado pelo cálculo de risco sobre as características do indivíduo (história familiar, hábitos, estilo de vida entre outros) para determinado evento adverso - a doença. A previsibilidade é realizada por estudos epidemiológicos e estudos baseados em estatísticas vitais; a intervenção é realizada com o objetivo de reduzir a mortalidade precoce pela adoção de novos comportamentos, ou seja, os comportamentos considerados de riscos, segundo estudos prévios, devem ser abandonados pelos indivíduos, sem medidas que alterem os determinantes estruturais; estratégia de risco ou abordagem de risco (risk approach - RA) é a vertente defendida por organismos e instituições governamentais para justificar alocação de recursos públicos e maximizar a eficiência das suas ações para os grupos menos favorecidos, ou seja, sob risco. Nesta vertente são envolvidos aspectos pessoais e socioecológicos. A aplicação geralmente está relacionada às populações dos países em desenvolvimento para que houvesse a redução das desigualdades 
sociais por meio de ações de atenção primária, porém sem discutir Políticas Públicas mais amplas de inclusão social; análise de risco (risk analysis/ assessment/management - RA/M) aborda o perigo do uso de tecnologias, segurança no uso de produtos e a percepção do público sobre o risco, e é uma vertente mais genérica.

\begin{abstract}
O modelo de estratificação social privilegia a etapa de distribuição e consumo de bens e serviços em detrimento da etapa de produção, isto é, classifica os indivíduos na estrutura social não por sua inserção no processo produtivo, mas por sua capacidade de se apropriar de bens e consumir serviços. A desigualdade [...] se confunde com o conceito de privação, ou seja, é tomada principalmente em sua dimensão de pobreza absoluta. [...] As investigações feitas com base nesse referencial adotam o paradigma do risco e utilizam em suas análises funções lineares de determinação mantendo a coerência com uma teoria que individualiza os diferentes aspectos das condições de vida, tomando um único ou cada um deles como fator de risco para problemas de saúde. [...] A maioria destes estudos perde o potencial de denuncia política uma vez que as desigualdades são interpretadas como resultado de maior ou menor empenho pessoal para alcançar a mobilidade na escala [...] (Barata, 2006, p.469).
\end{abstract}

Ao perder o potencial de denúncia política, esses estudos referendam o pensamento liberal no qual a mobilidade social do indivíduo depende exclusivamente de seus esforços para galgar posições sociais mais altas. Portanto, negam-se os processos de determinação da realidade permitindo responsabilizar o indivíduo por sua realidade e não contribuem para informar políticas sociais para modificá-la (Barata, 2006).

Breilh (2006, p.201) contrapõe o pensamento do paradigma do risco com o pensamento da epidemiologia crítica e afirma que aquele seria o modelo para uma "[...] adaptação funcional de uma vida estruturalmente insalubre [...]" contrariamente ao que propõe a epidemiologia crítica, a qual o autor defende como referencial teórico para a saúde coletiva emancipadora. Ao explorar dialeticamente as contradições das diferentes dimensões da realidade, a epidemiologia crítica busca modificar as bases da vida social "[...] tornando-a estruturalmente propícia ao desenvolvimento da saúde coletiva e individual [...]." 


\subsubsection{A teoria da determinação social do processo saúde-doença e a intervenção em saúde coletiva}

Nas diferentes escolas de interpretação epidemiológica o objeto é a "saúde-doença coletiva" que integra "dialeticamente o social e o natural", processo complexo que não pode ser reproduzido em laboratório ou em cálculos devido à sua relação com as forças sociais do contexto e a manipulação ideológica. A epidemiologia é uma ciência que interpreta e sustenta a causa de problemas sensíveis que afetam à população. No entanto, o conhecimento construído por ela pode ser utilizado para explicar a doença como um fenômeno individual e descontextualizado atendendo ao interesse da classe hegemônica que explora a força de trabalho e deteriora a qualidade de vida da maioria da população (Breilh, 1990).

Ao compreender a determinação social do processo saúde-doença busca-se reconhecer quais são os processos de produção e consumo daquela sociedade em determinado tempo histórico e que são determinantes nas formas de viver dos diferentes grupos sociais que ali se encontram, definindo os potenciais de fortalecimento e de desgaste da saúde expressos no processo saúde-doença, individualmente ou coletivamente. A historicidade do processo saúde-doença para Laurell (1983) é expressa em estudos que comprovam como tal processo ocorre nas coletividades humanas e não em casos clínicos individuais, pois é na coletividade que se percebe o desgaste do indivíduo pela sua inserção na produção, em determinada sociedade, em um determinado tempo.

A preocupação de Ayres (1997) na adoção da racionalidade epidemiológica apoiada no referencial da práxis científica é que esta pode levar à compreensão de que as relações se estabelecerão pela racionalidade da produção/re-produção social, esquecendo que nessas mesmas relações existe o caráter abstrato da epistemologia lógico-formal - intersubjetividade. O autor, baseado em Habermas, refere que: 
[...] um tratamento que desconsidere as relações trabalho/interação tenderá a oscilar entre duas alternativas igualmente insatisfatórias: ou toma a racionalidade da ciência como necessariamente associada a uma dada direção produtiva ou, inversamente, como agregado de princípios e conceitos que se organiza casualmente em torno de tais finalidades. Só assim seria plenamente pertinente a autonomia de uma "lógica da produção" como referência última, absoluta. Uma alternativa mais adequada [...] será apreender a práxis científica, assim como qualquer ação racional, como a resultante (aparentemente) una de construções (necessariamente) múltiplas de sujeitos diversos, portadores de diferentes projetos de mundo e poderes no mundo, em contínua e imprescindível interação material e simbólica. Em suma, nem determinismo material absoluto, nem espontaneidade relativista: a razão deve ser procurada (e, de preferência encontrada) na unidade produzida e produtiva na multiplicidade das "vozes" socialmente constituídas [...] (Ayres, 1997, p.31-2, grifos do autor).

Assim, para compreender o processo saúde-doença do indivíduo, deve-se ir além de dados que o caracterize pessoalmente e no seu grupo familiar, buscando-se também compreender a sua história e o significado das questões para o sujeito e as determinações da realidade observada nas suas diferentes dimensões. Portanto, considerando que a abordagem epidemiológica é definidora do modelo de assistência a ser implantado, acredita-se que compreender o indivíduo na sua totalidade é central para a definição da assistência integral, na qual se considera a transformação da realidade, assim como de sua determinação.

A partir de uma óptica progressista, pode-se asseverar que uma das lições hoje aprendidas por nós, cientistas de consciência crítica que trabalhamos no campo da saúde coletiva e da epidemiologia, é que nosso maior desafio, no momento atual, é o de aperfeiçoar nossa 'consciência objetiva' acerca dos novos problemas de uma realidade muito complexa e caracterizada por uma espiral de 'iniqüidade' crescente, mas fazê-lo trabalhando simultaneamente em prol de uma 'consciência da subjetividade' como ferramenta do impulso coletivo. E então, assim como reconhecemos a necessidade de incorporar no paradigma contra-hegemônico, de maneira mais rigorosa, toda a complexidade da realidade e as relações de produçãopropriedade e de poder, como condições 'objetivas' da materialidade social que determinam a saúde, começamos também a entender melhor a importância de trabalhar o tema da 'subjetividade social' como chaves para fortalecer o sujeito da ação, integrando forças e culturas contra-hegemônicas e construindo um poder simbólico e alternativo, sem o que é impossível sustentar um avanço emancipador (Breilh, 2006, p.24-5). 
A diferença entre linhas teóricas explicativas do processo saúdedoença é que, mesmo nas teorias com base positivistas, o fenômeno é compreendido na realidade observada, mas a questão é que nestas linhas, apesar da realidade ser explorada nas diferentes dimensões - estrutural, particular e singular -, não se evidenciam as contradições que existem entre as dimensões da realidade objetiva, assim como as contradições na própria dimensão. As explicações tendem a tomar a realidade a partir do concreto observado explicando-a por meio dos fatores que a determinam. Logo, para intervir nos problemas de saúde, opta-se pela seleção do fator de maior peso (unicausalidade) ou por mais de um fator que caracteriza um conjunto de determinantes de maior peso (multicausalidade). Neste caso retorna-se à redução do pensamento para compreender tal realidade, pois não há compreensão sobre a participação dos processos de determinação do processo saúde-doença, ainda que este ocorra de forma articulada e hierarquizada (Breilh, 2006; Barata, 2005).

Os estudos com referencial da epidemiologia social desenvolvidos na América Latina para compreender a determinação do processo saúdedoença têm utilizado a categoria de classe social como conceito básico, porém Breilh (2006) reflete que esta categoria não contempla outros processos que determinam as inequidades sociais dessas realidades. Para o autor, as relações de poder nas sociedades latino-americanas são estruturadas pelas categorias: classe social, gênero e etnia. Logo, para compreender a determinação dos processos de inequidades sociais há que se perceber a determinação dos processos de concentração de poder nas sociedades que estão relacionados a estas três categorias. Destaca a categoria gênero como a que antecede as outras duas nas relações de poder na sociedade, que se originou da apropriação privada de riqueza por grupos étnicos que se encontravam estrategicamente em vantagem no momento histórico. Nesse sentido conceitua inequidade como:

A 'ineqüidade' é uma categoria analítica que dá conta da essência do problema, ao passo que a 'desigualdade' é uma evidência empírica que se torna ostensiva nos conjuntos estatísticos, para cuja compreensão adequada é preciso desvendar a ineqüidade que a produz. A desigualdade é uma injustiça ou iniqüidade (com 
'i') no acesso, na exclusão produzida com respeito à fruição, uma disparidade na qualidade de vida, ao passo que a ineqüidade (com 'e') é a falta de equidade, ou seja, é a característica inerente a uma sociedade que impede o bem comum e instaura a invisibilidade de uma distribuição humana que outorgue a cada um conforme sua necessidade, e the permita contribuir plenamente conforme sua capacidade (Breilh, 2006, p.210-1).

A expressão dessas relações de poder pode ser identificada nas classes sociais nas sociedades, pois estas conformam os indivíduos em grupos homogêneos que estão alocados em determinadas posições sociais de acordo com a dinâmica e historicidade do contexto em que vivem. Barata (2005, p.15) afirma que "[...] pessoas com determinada renda não são alocadas aleatoriamente em determinadas posições sociais, mas chegam a elas através de trajetórias dinâmicas de vida moldadas pelo contexto no qual vivem [...]". E ainda que em estudos nos quais se abordam a realidade como algo complexo, composto de partes isoláveis que são possíveis de serem decompostas para se perceber a ação específica de cada parte no fenômeno observado, há um engano, pois desse modo recairiam no conceito de causalidade. Ao contrário, no conceito de determinação social os processos sociais não necessitam isolar completamente as variáveis envolvidas e "[...] a maioria das relações são contingentes [...] nem necessárias nem suficientes em si mesmas".

Samaja (2003) defende a construção de um modelo explicativo para a epidemiologia que permita explorar a dinâmica da realidade por meio da perspectiva dialética sobre as relações das populações com o meio ambiente, uma proposta que busca aproximar os conhecimentos da geografia marxista com a determinação social do processo saúde-doença. Afirma que tanto a epidemiologia como a geografia têm como esforço pensar histórica e concretamente a existência humana em sua totalidade, em um determinado espaço. O espaço, no caso território, é definido pelo autor baseado no referencial de Milton Santos, geógrafo brasileiro que defende a reintrodução do sujeito nos espaços e nos objetos da geografia, uma vez que este vem sendo desconhecido no movimento de globalização da economia. Nesse movimento identifica o afastamento da visão crítica dos conhecimentos desenvolvidos em disciplinas científicas, pois isso influencia o desenvolvimento de pesquisas, 
tornando-as puramente pragmáticas no sentido de atender aos interesses de instituições financiadoras em detrimento do interesse da população em geral.

Para contrapor esse pensamento e para atender ao interesse da população, deveriam ser desenvolvidos estudos baseados na epidemiologia crítica e estes deveriam ser utilizados para a organização dos serviços de saúde. Nesse sentido, as intervenções e a implementação de políticas no setor buscariam reverter a determinação do processo saúde-doença identificado em diferentes grupos. Fundamentados na proposta teórica da Epidemiologia Crítica e dos princípios do Sistema Único de Saúde, o Planejamento em Saúde permitiria, a partir da realidade encontrada, intervir para transformar as situações indesejáveis com ações intersetoriais acessíveis por meio de um sistema de saúde de fato universal e equânime, o que significa mudar o enfoque no risco de desenvolver doenças e agravos do atual modelo assistencial que privilegia ações curativistas e individuais, para um modelo que identifique os processos de determinação do processo saúde doença, assim como da vida em determinados territórios.

Para Breilh (2006), esses processos, individuais ou coletivos, podem ter facetas que são consideradas como benéficas/protetoras (saudáveis) ou destrutivas/deteriorantes (insalubres) para a vida em uma determinada sociedade. E ainda que "[...] pode corresponder a diferentes dimensões e campos da reprodução social e pode, além disso, tornar-se protetor ou destrutivo, conforme as condições históricas em que se desenvolva a coletividade correspondente" ( p.203).

As facetas protetoras ou deteriorantes estão juntas no mesmo processo e muitas vezes estão invisíveis na realidade. A invisibilidade ocorre porque uma das facetas pode estar atenuada ou dominada em um determinado momento na realidade. Para a epidemiologia, é necessário reconhecer qual faceta do processo predomina no modo de vida de uma formação social porque esta é determinante para a saúde e para a definição da ação que será desenvolvida. A ação para evitar ou se contrapor a processos destrutivos é de prevenção de adoecimentos e a ação para fomentar as facetas protetoras é de promoção da saúde. A epidemiologia atua com processos e 
por isso muitas vezes promove mudanças profundas sem necessariamente atuar com as pessoas por intervir na determinação-chave da saúde.

\begin{abstract}
A epidemiologia empírica e o paradigma dos fatores de risco, ao reduzirem a realidade ao plano empírico, ao deterem o movimento e ao fracionarem essa realidade, ficam inaptos a conhecer o movimento da determinação e a ligação dos processos com a vida social em seu conjunto, e tanto uma limitação quanto a outra têm conseqüências importantes na atividade epidemiológica. O fato de não se permitir a compreensão da gênese dos processos e de se ficar reduzido aos fenômenos 'terminais' é um grave obstáculo [...] o fato de não se articularem diagnósticos que integrem as determinações de saúde leva a uma lógica da focalização que contradiz uma visão da saúde coletiva como âmbito de emancipador (Breilh, 2006, p.205).
\end{abstract}

\title{
5.3 SERVIÇOS DE SAÚDE: PLANEJAMENTO E PROGRAMAÇÃO NA DEFINIÇÃO DA INTERVENÇÃO
}

Para compreender o planejamento, a programação e gestão no Sistema Único de Saúde (SUS) é necessário refletir sobre o movimento da Reforma Sanitária brasileira que foi a base para a construção do modelo de atenção à saúde proposto pela atual política de saúde brasileira. Com esta finalidade, há que resgatar alguns aspectos da história das mudanças na assistência à saúde no Brasil para, posteriormente, refletir sobre o planejamento em saúde.

A assistência à saúde no Brasil passou por significativa mudança com a implantação do Sistema Único de Saúde. A partir da implantação desta política no setor, construída no movimento da Reforma Sanitária e regulamentada pela Constituição Federal de 1988, Leis Orgânicas da Saúde n. ${ }^{\circ} 8.080 / 90$ e n. ${ }^{\circ} 8.142 / 90$, buscou-se garantir assistência à saúde como direito do cidadão e dever do Estado. Até então a assistência à saúde no país era prestada para dois grupos basicamente: o grupo dos trabalhadores com registro em carteira de trabalho que contribuía compulsoriamente para a previdência e, assim, tinha acesso à assistência à saúde nos órgão do setor e conveniados ao mesmo; o outro grupo, considerado como não-previdenciários 
ou indigentes, contava com a assistência prestada por alguns hospitais públicos e da rede privada conveniada a este, ou por entidades filantrópicas que desenvolviam ações de cunho social. As intervenções em saúde eram, predominantemente, desenvolvidas para combater o adoecimento no indivíduo por meio de atividades hospitalares ou ambulatoriais. Ao Ministério da Saúde, Secretarias de Saúde dos Estados e dos Municípios, cabiam, basicamente, ações de promoção da saúde e prevenção de doenças de caráter coletivo, com ênfase em campanhas de vacinação e controle de doenças endêmicas ou que apresentavam índices epidêmicos. Com relação à assistência individual à saúde, estes órgãos atuavam de forma bastante limitada (Brasil, 2003).

Na busca de reverter o quadro descrito acima, a Constituição Federal garantiu em seu texto o direito à saúde por meio da adoção de políticas econômicas e sociais justas que viabilizassem o acesso ao trabalho e consumo de bens para atender às necessidades básicas dos indivíduos a qualidade de vida. A criação do Sistema Único de Saúde está fundamentada nesses princípios e aponta também outros princípios para a assistência à saúde, nos quais se destacam: a universalidade da cobertura nos atendimentos, pressupondo a integralidade do indivíduo na assistência; a descentralização da gestão dos serviços com a participação popular; a integração, regionalização e hierarquização do sistema de serviços; a complementaridade do setor privado às ações do setor público, quando este não dispuser do recurso para atender às necessidades da população; intervenções articuladas com outros setores, intersetorialidade, considerando o conceito ampliado de saúde e a determinação social do processo saúde-doença. A construção deste sistema tem sido nas últimas décadas permeado de contradições, avanços e retrocessos determinado por dificuldades de naturezas diversas impostas ao movimento que aponta mudanças que vão contra o interesse de segmentos até então beneficiados pelo modelo de atenção à saúde vigente. Nesse momento do estudo serão explorados os aspectos relacionados às mudanças no planejamento e programação das intervenções em saúde no sentido de refletir sobre o processo e compreender o modelo a elas preconizado nos atuais serviços públicos de saúde. 
[...] a reorientação da construção política e da organização tecnológica do processo de trabalho no âmbito dos sistemas nacional, estaduais e municipais, tendo como perspectiva a planificação, programação e operacionalização de ações e serviços voltados à melhoria das condições de vida e saúde com redução das desigualdades sociais, exigiria, em primeiro lugar, um grande investimento na difusão do enfoque epidemiológico, paralelamente ao processo de descentralização da gestão do sistema para estados e municípios (Teixeira, 1999, p.289).

Antes de avançar na discussão da gestão dos serviços de saúde cabe destacar uma característica do Estado brasileiro para possibilitar a compreensão de outras questões que serão exploradas a seguir. O Brasil é caracterizado como um Estado federativo, isto é, se organiza em três esferas de governo - União, Estados e Municípios - cada uma com autonomia política, administrativa e financeira, sem vinculação hierárquica, conforme garante a Constituição da República de 1988. Esta organização é considerada adequada para países com características regionais diversas. E, no caso brasileiro, esta diversidade se expressa também nas desigualdades sociais. Nesse contexto, as políticas sociais têm objetivo de minimizar as desigualdades e garantir a inclusão social, sendo, portanto, responsabilidade de cada esfera de governo a adoção de Políticas Públicas favoráveis a tal objetivo, pela adoção de mecanismos que propiciem a articulação, cooperação e complementação entre os diferentes setores que se encontram sob sua responsabilidade (Mendes, 1998; Paim, 2006).

Para Campos, Barros e Castro (2004), a atuação do setor saúde pressupõe ações intersetoriais que referendem o conceito de saúde ampliado e é por meio destas que se deve intervir na determinação do processo saúdedoença para promover a saúde e prevenir as doenças. Logo, cabe ao Estado, nas diferentes esferas de governo, assumir a efetivação de políticas sociais e econômicas mais justas, ratificando o engajamento do setor saúde na busca de condições de vida digna e do pleno desenvolvimento da cidadania. Assumir o enfrentamento das questões de saúde, no contexto da sociedade brasileira, pressupõe implantar ações de âmbito coletivo para promover saúde mediante intervenções que atuem tanto na determinação das desigualdades sociais como na determinação dos problemas de saúde da população. 
A ampliação de ações e o aumento da cobertura das intervenções em saúde têm se dado por meio da implantação de serviços municipais de atenção básica com o objetivo de garantir a reversão do modelo de intervenção desenvolvido no país, que historicamente é curativista e hospitalocêntrico, para o modelo de atenção básica em saúde. Nesse último, preconizam-se intervenções de promoção da saúde, prevenção das doenças e, consequentemente, a melhoria da qualidade de vida das populações. No processo que vem sendo construído, desde o início da década de 1990, observa-se o deslocamento da responsabilidade da assistência à saúde para os municípios, processo de municipalização dos sistemas de saúde, tornando a gestão destes serviços mais próxima das realidades dos usuários.

A reorientação na gestão implica ainda a reorientação do financiamento, organização, definição do modelo assistencial entre outras questões políticas e administrativas. No Brasil, a partir da implantação do SUS, têm-se verificado algumas experiências que buscam ampliar a democracia em instituições de saúde, como a descentralização de poder para os municípios (municipalização) e a instalação de Conselhos e Conferências de Saúde, com a participação de usuários. Apesar da relevância dessas medidas, elas ainda demonstramse insuficientes para alcançar os objetivos do SUS, bem como para diminuir a alienação constatada na maioria dos trabalhadores (Campos, 1998). Para o autor, em algumas experiências, observam-se momentos de participação, mas estes não chegam a modificar o sistema de gestão dos serviços de saúde, que tem se resumido a oficinas de planejamento ou territorialização, que na prática perdem poder para o modelo de gerência tradicional, no qual o enfoque é controlar a realização de procedimentos técnicos, o comportamento formal dos funcionários e a elaboração de normas e rotinas.

Para Teixeira (1999), a formulação e implementação de políticas de financiamento e gestão do SUS que objetivam a promoção da equidade pela redução da desigualdade social é um grande desafio para o setor saúde, porque se posiciona contrariamente ao modelo hegemônico - curativista, hospitalocêntrico - redefine o modelo de assistência à saúde e reorganiza o processo de trabalho em saúde. Este processo de reversão não pode prescindir da epidemiologia que, ao ser articulada com outras áreas de conhecimento, 
contribui para os processos de formulação de políticas, gestão, planos e programação em saúde, uma vez que permite compreender as realidades locais mostrada pelos parâmetros de morbidade e mortalidade. A autora assinala que o uso da epidemiologia para o Planejamento em Saúde não se limita à discussão técnica, ao contrário, referenda que este tem caráter eminentemente político ao definir e priorizar regiões para receber as intervenções em saúde, assim como define o modelo de atenção a ser desenvolvido, os recursos a serem aplicados de acordo com a possibilidade técnico-organizativa, econômico-financeira de cada unidade - município ou estado. Paim (1999) refere que cabe à epidemiologia contribuir tanto no estudo das desigualdades sociais quanto na planificação, gestão e avaliação das intervenções em saúde, no uso de tecnologias e, ainda, acompanhar o processo de análise do impacto dessas ações nos níveis de saúde da população.

Neste estudo compreende-se o planejamento em uma sociedade democrática como uma ação social que pensa antecipadamente a intervenção, para a realização do trabalho, por explicitar objetivos, compromissos institucional, social e coletivo. No setor público a ação planejada pode ser a estruturação de uma política, planos, programas e projetos de um órgão de governo elaborados para atender às demandas da sociedade. Para o cidadão, é a possibilidade de acompanhar a ação governamental no atendimento às suas necessidades. Ao ser desenvolvido em instituições públicas, no caso tomando o setor saúde como exemplo, há que se destacar os compromissos que o permeiam, pois não se pode correr o risco de improvisar em ações que intervêm na vida de pessoas e ainda que tenham recursos públicos nos seus desenvolvimentos. Para os envolvidos no processo, usuários, trabalhadores e gestores, o planejamento torna claros os objetivos e as metas das atividades e ações que estão sob suas responsabilidades e, assim, compromete-os no acompanhamento dos trabalhos que têm sob sua responsabilidade (Paim, 2006).

Sala (1993) define programa de saúde como um conjunto de atividades articuladas e organizadas, a partir de um referencial epidemiológico, para produzirem um efeito na saúde no plano coletivo. Ao considerar a ação programática em saúde como um processo de trabalho, o autor destaca suas características como sendo a utilização dos conceitos da epidemiologia 
para a apreensão do objeto de trabalho e desenvolvimento de intervenções sobre a saúde e doença, controle das atividades e a verificação dos efeitos na saúde e doença no nível coletivo. Para Schraiber (1993), a programação em saúde é uma tecnologia de organização do trabalho assistencial aplicada no âmbito da atenção primária que trata, por meio da integração médicosanitária, das necessidades no plano individual e coletivo, sendo que as necessidades objetivadas no plano individual estão consubstanciadas no plano coletivo.

A relevância do uso do conceito de risco nas ações programáticas se justifica por dois pressupostos dialéticos, segundo Ayres (1995b): a ampliação de cobertura serviços não significa aumento de efetividade nas ações e a demanda espontânea nos serviços de saúde não representa as necessidades em saúde experimentadas cotidianamente pelos indivíduos. O autor afirma que a ampla utilização do conceito de risco para orientar a ação programática se deu pela pura falta de um rigor metodológico para tal, e assim o enfoque se consolidou como um discriminador de probabilidades para danos em indivíduos, famílias e grupos, ganhando espaços na investigação científica, bem como aderência nas representações do senso comum.

[...] embora o núcleo tecnológico do trabalho em saúde seja o fundamento da relação entre esses dois sujeitos genéricos - serviço de saúde e população - as práticas assistenciais não podem ser pensadas como ações estritamente técnicas sem reduzir o pólo população a uma realidade "plana e estanque" [...]. Se recorremos ao risco para evitar a "morte" do sanitário como esfera objetiva de necessidades, se queremos resgatar pelo social a autêntica subjetividade de "nossos" objetos de prática, então a relação entre risco e programação precisa ser revista. Precisaremos incorporar a nossas práticas cotidianas a idéia do risco como construção abstrata de caráter sempre (imediatamente) prescritivo, e o caráter quasetecnológico da programação. Talvez assim, sem a descaracterização ideológica de qualquer um dos lados, possamos conseguir efetiva expressão dos sujeitos envolvidos no grande diálogo das práticas de saúde, no qual a técnica não é senão um entre as diversas linguagens utilizadas (Ayres, 1995b, p.73, grifos do autor).

Uribe Rivera (1989) defendeu a proposta de elaboração de programação local em saúde com enfoque estratégico. A fundamentação desta foi, segundo os trabalhos de Castellanos (1987), sobre a epidemiologia social e sobre o planejamento estratégico-situacional de Matus (1987). Assim, para um modelo 
de contraposição ao planejamento e programação normativa, o autor apontou a necessidade de se avançar na construção do modelo explicativo sobre os problemas observados, principalmente de saúde-doença, no complexo de relações que se estabelecem nos múltiplos processos, nos diferentes planos e espaços que os geram. Afirmou ainda que o uso do enfoque de risco para o planejamento em saúde seria possível uma vez que este estivesse subordinado a um enfoque mais amplo, no qual se analisassem qualitativamente os processos causais das doenças superando o espaço singular dos fenômenos e, refletindo sobre suas dimensões particulares e gerais. E que com relação à predição considerasse o complexo cenário socio-políticoeconômico-epidemiológico envolvido na causação de danos.

Ao refletir sobre uma nova prática da epidemiologia, na qual reconhece o papel de construção de um projeto emancipador, Breilh (2006) afirma que o fazer institucionalizado, em uma sociedade que segue a lógica do mercado, é uma forma de dominar a prática, e a esta se estabelece a estreita relação com o processo de pensar e de geração de sujeitos, ou seja, é assim que se consolida a estreita relação entre a subjetividade e a ideologia dos indivíduos. Um dos desafios apontado pelo autor é que a epidemiologia deveria romper com a racionalidade influenciada pelo pensamento positivista que the imprime uma maneira simplista e reducionista para compreender a realidade, o que não permite compreender sua complexidade e diversidade.

Na perspectiva de implantar um processo de intervenção em saúde que considere a realidade local e regional, as regulamentações para orientar a gestão dos serviços de saúde do sus têm avançado e, entre estas regulamentações, a Norma Operacional Básica de 1996 (NOB/96) se destacou nos últimos anos. Em 2006 ocorreram a aprovação e implantação das Diretrizes Operacionais para o Pacto pela vida, em defesa do SUS e de sua gestão como mais um avanço nesse sentido. Para o Ministério da Saúde (Brasil, 2006), o processo de descentralização tem aproximado o Sistema de Saúde da realidade social, política e administrativa de cada região e município. Portanto, os desafios que se colocam são a superação do modelo fragmentado de atenção à saúde, a organização da rede de serviços regionalizada e hierarquizada e a qualificação da gestão. 
Mendes (1998) discute a reorganização dos serviços de saúde e aponta que sua viabilidade está relacionada à capacitação do processo de trabalho em saúde em suas diferentes dimensões: dimensão política, referida como o espaço de luta entre os atores envolvidos e os diferentes interesses que os mobilizam para tal direção; dimensão ideológica, na qual se encontram os diferentes paradigmas assistenciais para solucionar os problemas de saúde, que também são considerados segundo as diversidades culturais envolvidas no processo; e a dimensão técnica, intimamente relacionada às dimensões anteriores e, dependente das definições delas para ser estabelecida e tornar o processo de mudança factível.

O trabalho em saúde é considerado complexo, diversificado e sujeito a imprevistos, exigindo daquele que o executa a improvisação, criatividade e iniciativa. Logo, torna-se fundamental a associação entre autonomia e responsabilidade. Para Campos (1997), a autonomia responsável no trabalho deve ser preservada, pois ela sofre interferência de outros processos inerentes ao trabalho no setor saúde, entre os quais destaca a disputa de poder, a falta de recursos, a alienação, os interesses pessoais ou coorporativos e a burocratização. Quanto à alienação, o autor considera que "[...] se o profissional não se sente sujeito ativo no processo de reabilitação ou na trajetória de invenção de programas, perderá seu potencial criativo e tenderá a não se responsabilizar pelo objetivo final da própria intervenção [...]" (Campos, 1997, p.235).

As reflexões sobre o processo de trabalho em saúde sob a luz dos referenciais do Materialismo Histórico Dialético têm contribuído para elucidar a complexidade dos processos que o conformam. Ao longo da história da saúde pública verifica-se que o processo de trabalho em saúde está relacionado ao contexto macrossocial no qual ocorre, destacando-se o pensamento hegemônico nas explicações do adoecimento e as descobertas científicas para o enfrentamento das doenças e o modelo de assistência para populações, comunidades, famílias e indivíduos. É nessa perspectiva que se reflete sobre a organização dos serviços de saúde nos últimos anos, principalmente a partir da década de 1990. 
No período a influência dos organismos financeiros internacionais, Banco Mundial, Fundo Monetário Internacional (FMI) e Banco Interamericano de Desenvolvimento (BID), foram significativos na formulação de políticas para o setor dos países em desenvolvimento. As recomendações foram para que se reduzissem gastos públicos supostamente elevados em programas sociais. No Brasil o alinhamento às recomendações destes organismos foi significativo a partir da década de 1990. Assim seguiu-se a recomendação de redução do papel do Estado no desenvolvimento de ações sociais, deslocando-o para organismos não governamentais na medida em que estes se dispusessem. Nos serviços de saúde sob a responsabilidade do Estado recomendou-se o aumento da cobertura de ações mais simplificadas que dessem conta de atender às demandas daqueles que necessitavam da assistência pública. $\mathrm{Na}$ assistência à saúde caberia aos envolvidos responsabilizar-se individualmente pelo resultado da intervenção, neste caso, trabalhadores e usuários (Gentille, 1998).

Segundo Campos (1997), os trabalhadores de saúde são produtos do sistema de relações em que estão mergulhados, mas ao mesmo tempo são produtores deste sistema. Assim, tornam-se sujeitos e objetos ao mesmo momento. Como objetos são produzidos pelas políticas governamentais, pelo saber estruturado em disciplinas, pelo mercado de trabalho, pelas leis e valores de cada época e em cada sociedade. Como produtores configuram-se como construtores de saberes, influenciam políticas e participam da estruturação da comercialização da saúde e da doença por serem os principais divulgadores dos princípios gerais das políticas e modelos de atenção à saúde.

No desenvolvimento da assistência o trabalhador de saúde, por muitas vezes, repete ações que se dão de maneira fragmentada, seguindo as normas e as regras previamente estabelecidas, sem considerar o usuário com o direito de participar na definição e escolhas. Contraditoriamente, o Sistema Único de Saúde, como já descrito anteriormente, promulga a intervenção em saúde que tenha enfoque nas necessidades em saúde do usuário e na determinação de seu processo saúde-doença, respeitando-se o princípio da integralidade, no qual o indivíduo deve ser visto em sua totalidade, logo capaz de ser sujeito no processo de intervenção. 
O trabalho em saúde é percebido por Mendes-Gonçalves (1992) (o autor toma a medicina como exemplo) como algo elaborado como se as dimensões da realidade estivessem externas a ele. As dimensões internas que fazem parte do trabalho seriam a forma de pensar, técnica e cientificamente, a criatividade, o humanismo e a neutralidade. No agir é como se houvesse uma única medicina para intervir na realidade, o que o autor critica e aponta o seu desejo: que as realidades (considera não ser apenas uma) invadam os espaços exclusivos da medicina e os "tomem" com suas diferentes maneiras de reprodução histórico-social.

[...] a práxis da saúde não é totalmente objetiva, ou seja, sujeita ao condicionamento coletivo, nem tampouco absolutamente subjetiva, ou seja, sujeita exclusivamente ao livre arbítrio pessoal. A práxis da saúde, por conseguinte, não é nem totalmente relativa nem totalmente determinística - é um movimento incessante do micro para o macro, e vice-versa, que se desloca entre o movimento generativo e o reprodutivo (Breilh, 2006, p.45).

A reivindicação para que o modelo de atenção à saúde seja fundamentado nas necessidades em saúde tem sido foco central de alguns estudiosos (Breilh, 2006; Mendes, 1998; Paim, 1999; Brasil, 2006) que refletem sobre a importância de se reverter o foco na doença para necessidades em saúde com a participação dos sujeitos históricos e socialmente determinados na definição das políticas de saúde a serem implantadas. Na atenção básica em saúde se tem um menor custo que na atenção especializada, porque se busca manter o indivíduo saudável, enquanto na atenção espe-cializada a intervenção está voltada para o desenvolvimento de cuidados com alta tecnologia na perspectiva de manterem vivos indivíduos já doentes.

[...] Os sistemas de livre demanda, descuidados da organização da atenção primária, têm foco na doença; seus sujeitos são individuais; não reconhecem uma dimensão territorial; prestam atenção ocasional e passiva; enfatizam, relativamente, os cuidados curativos e reabilitadores; negam a possibilidade de relações interpessoais constantes, desumanizando a atenção à saúde; respondem mecanicamente a demandas derivadas da auto-percepção dos usuários; estão abertos à demanda direta em quaisquer de seus níveis; os especialistas tendem a solicitar mais exames que os generalistas; atuam permanentemente a jusante quando já se perdeu a saúde; e estão pressionados pela concentração da demanda em hospitais e unidades especializadas. Por conseqüência tendem a ser ineficazes e ineficientes (Mendes, 1998, p.75-6). 
A reversão do atendimento à saúde e do foco dos programas para a promoção da saúde e prevenção de doenças tem de ser realizada por meio de um processo que pressupõe participação e discussão, pois historicamente setores hegemônicos decidem e justificam a substituição destes definindo quais as necessidades dos usuários do sistema deverão ser atendidas. Para Breilh (2006), esse é um processo que demonstra que os direitos à saúde não são inalienáveis, mas sim que as necessidades são discriminatórias em um pacote mínimo para os pobres, uma preparação conveniente de terreno para a mercantilização no setor.

$\mathrm{Na}$ apresentação das diretrizes para Programação Pactuada e Integrada da Assistência à Saúde com o objetivo de reverter o modelo de gestão em saúde, o Ministério da Saúde (Brasil, 2006, p.18) registra a concepção de necessidades em saúde que fundamenta o documento.

\begin{abstract}
As necessidades em saúde são aqui consideradas como estimativas de demanda de ações e serviços de saúde, determinadas por pressões e consensos sociais provisórios, pelo estágio atual do desenvolvimento tecnológico do setor, pelo nível das disponibilidades materiais para sua realização, legitimadas pela população usuária do sistema e pelos atores relevantes na sua definição e implementação. Pretende-se superar, assim os enfoques utilitaristas marcados pelo viés subjetivo e individual, apontando-se para a criação de consensos normativos sobre os níveis adequados de oferta de bens e serviços a serem providos pela ação setorial, tanto no campo da atenção, como no campo da promoção à saúde, este último condição essencial para a elevação dos patamares de autonomia e ampliação das capacidades individuais e coletivas para a busca da saúde.
\end{abstract}

Com a perspectiva acima, ele ressalta o pensamento de Paim (2006) ao afirmar que o planejamento "[...] ao explicitar seus objetivos e finalidades, pode favorecer a democratização da gestão e reduzir a alienação dos trabalhadores de saúde no processo de produção [...]". Acredita-se que, além disso, a proposta pactuada entre os gestores do SUS é uma possibilidade de se reverter o processo de gestão em saúde que, muitas vezes, ocorre sem previsibilidade e serve para gerenciar os meios para o desenvolvimento da assistência à saúde, mas não faz reflexão sobre a determinação do processo saúde-doença, das enormes demandas espontâneas nos serviços, das longas filas de espera, da não resolutividade das ações, entre outras questões que 
são produtos da intervenção em saúde ineficaz e, portanto, um processo que tem sido crônico no reforço da desigualdade social e inacessibilidade aos serviços do setor.

\subsection{PARTICIPAÇÃO POPULAR NA DEFINIÇÃO DE DIRETRIZES PARA AS POLÍTICAS PÚBLICAS DE SAÚDE}

Ao explorar as bases teóricas sobre o tema - participação popular buscou-se compreender a construção histórica do processo participatório na sociedade brasileira, uma das diretrizes do Sistema Único de Saúde, para refletir sobre o seu significado nos atuais espaços colegiados do setor saúde, as regulamentações que garantem esse exercício de cidadania e sobre a contribuição desse processo na definição das Políticas Públicas que tem como finalidade reconhecer e atender às necessidades em saúde dos indivíduos, grupos e populações.

\subsubsection{Os movimentos sociais no Brasil: a construção da participação popular na definição de Políticas Públicas}

A participação popular compõe o processo de exercício de cidadania em uma sociedade democrática, na qual representantes dos movimentos sociais organizados participam, junto com gestores públicos e outros segmentos da sociedade, na elaboração das Políticas Públicas para orientar os serviços e ações que estão sob a responsabilidade do Estado. No setor saúde o objetivo é atender às demandas e necessidades da população de um determinado território e a participação é por meio de representação em comitês, conselhos, conferências, entre outros espaços referendados legalmente para tal. Nos fóruns citados cabe aos representantes dos movimentos sociais organizados expressarem as demandas daqueles que representam e influir para que 
suas necessidades sejam atendidas, sem perder de vista que aos serviços públicos cabe desenvolver as intervenções que forem mais adequadas para a coletividade (Valla, 1992, 1998; Cortes, 2002; Carvalho, 1995, Gohn, 2004; Cohn, 2003; Moreira; Escorel, 2009).

O exercício da cidadania por meio dos movimentos sociais organizados permite aos indivíduos não apenas expressar suas necessidades e demandas para que estas sejam reconhecidas, mas também participar em processos para avaliar como os serviços públicos são organizados para o desenvolvimento de ações e, ainda, qual foi o impacto destas na transformação de suas realidades (Carvalho; Santos, 1992; Valla, 1998).

No Brasil a discussão sobre a participação popular teve início nos anos 1930 e 1940 quando surgiram as Políticas Públicas elaboradas no sentido de prever a infraestrutura do Estado necessária para atender às demandas das grandes concentrações produtivas nas áreas periféricas das metrópoles brasileiras - população e indústrias. Nesse processo o Estado passou a ter o papel de provedor dos recursos necessários para atender às demandas e o atendimento se dava por meio de serviços públicos prestados, financiados com verba pública, ou seja, financiado por meio do recolhimento de taxas e impostos pagos ao governo (Valla, 1992).

A participação de representantes da sociedade civil, movimento social organizado, em esferas públicas democráticas com o objetivo de garantir políticas que atendessem às necessidades do cidadão é, portanto, uma reivindicação histórica. Nas reivindicações dos movimentos populares estavam incluídos o acesso a bens, serviços e direitos sóciopolíticos, até então negados àqueles que não pertenciam às classes dominantes da sociedade (Gohn, 2004).

A ideia de participação popular era parte do projeto de sociedade que se contrapunha ao modelo daquelas, nas quais os sujeitos que tinham recursos e estudos definiriam "o caminho correto" para as classes mais pobres. Entretanto, Valla (1998) refere que ao longo dos anos o Estado pouco fez para a população das classes populares e os poucos serviços públicos se mostraram ineficientes no sentido de intervir para promover condições mínimas de vida para estes grupos. 
Nos anos 1970, os movimentos sociais brasileiros tiveram força ao se posicionarem contrariamente às diretrizes das Políticas Públicas desenvolvidas pelos dirigentes da ditadura militar. Neste processo o princípio da autonomia foi o eixo articulador que levou movimentos sociais a se organizarem para mobilizar os cidadãos a participarem dos debates e das manifestações contrários às políticas de Estado que muitas vezes Ihes negavam direitos. Reconhecidamente essas participações eram relacionadas aos sindicatos e aos partidos políticos, em movimentos que se contrapunham ao poder governamental. Portanto, a participação nos movimentos era considerada como desobediência e resistência civil ao regime de governo vigente. As decisões eram estabelecidas em assembleias e as reivindicações eram centradas na luta pela liberdade e pela justiça social. Porém, ao mesmo tempo em que se buscava garantir o princípio da autodeterminação, considerado componente fundamental na construção da autonomia, os movimentos populares tinham apoios em bases e assessorias externas ao próprio movimento. Gohn (2004) refere que nesse contexto os princípios defendidos se tornaram relativos e as diferenças entre as lideranças e os que eram representados ficaram perceptíveis, porque os líderes seguiam as referências estabelecidas externamente e se afastavam das demandas de seus grupos.

A preocupação apontada por Valla (1998) é que a conjuntura política e econômica dos países de economias periféricas tem trazido novas interpretações para a definição de participação popular, o que levaria a compreendê-la como a integração de grupos marginalizados à sociedade e, ainda, que a execução de uma ação para benefício coletivo seria por meio de manifestações voluntárias, exemplificando com os mutirões. Assim, referenda-se que os excluídos precisam ser estimulados a participar dos benefícios do desenvolvimento econômico e científico. Portanto, para o autor, está implícita a idéia de que a exclusão se dá devido à ignorância e passividade destes cidadãos. Logo, nega-se a determinação macroestrutural das demandas e necessidades.

Nas últimas décadas, o ajustamento estrutural das economias nos países em desenvolvimento, recomendado pelas agências internacionais, 
tem levado países com enormes problemas sociais e econômicos a adotarem estratégias que atendam minimamente às demandas das classes populares, e como exemplo destes ajustes encontra-se o Brasil. As recomendações de estratégias para as reformas estabeleceram o Estado Mínimo, ou seja, segundo as teorias econômicas neoclássicas, o Estado deixava de ser o indutor de crescimento econômico e de bem-estar social para que estes fossem regulados pelo mercado (Cortes, 2002).

Gohn (2004) afirma que no Brasil, nos anos de 1980 e 1990, o cenário foi bastante conturbado, pois além das mudanças econômicas e políticas promovidas para estabelecer o Estado Mínimo, houve mudanças incisivas na sociedade com a queda da ditadura militar, abertura política, eleições diretas, entre outros fatos. Assim, as Políticas Públicas para atender às demandas da população foram influenciadas por questões com repercussão foi mais acentuada nas áreas urbanas, principalmente nas grandes cidades. Nesse contexto houve a ampliação da mobilização e da participação popular com a criação de movimentos sociais e instituições para representar os interesses dos segmentos populares. Para tal, foram criadas associações, instituições de naturezas diversas e organizações não governamentais. Para a autora, nesse período se reconhece o deslocamento do objeto dos movimentos sociais, pois eles deixaram de ter a centralidade na busca da autonomia dos membros da sociedade civil e passaram a desejar a ocupação dos espaços de poder instituídos nos aparelhos do Estado como representantes de determinados segmentos.

As instituições não governamentais surgidas no período (1980-1990) devem ser vistas com ressalva, segundo a autora (Gohn, 2004), porque estas passaram a ser mediadoras entre o interesse do cidadão e das instituições financiadoras de projetos sociais e, assim, as intervenções sociais passaram a ser desenvolvidas. Nesse sentido, os organismos que se habilitaram a representar o movimento social organizado - associações, instituições e Organização Não Governamental (ONG) - construíram alianças com os movimentos sociais, e o que poderia ser um processo mobilizador para o desenvolvimento da autonomia por meio da melhora de condições de vida, passou ser um processo para integrar os excluídos a bens que thes 
permitissem a sobrevivência, sem contribuir para sua organização e autonomia. Ao contrário, o atendimento ao sujeito, individualmente, era garantido com acesso à assistência social em diferentes projetos financiados por organismos nacionais e internacionais que promoviam ações assistenciais fragmentadas como compensação pela exclusão social. Essas situações foram encontradas principalmente nas instituições que não eram legítimas do movimento popular, mas foram criadas pela necessidade da mediação - financiadores e sujeitos a serem beneficiados - para depois se buscar parceria com grupos e populações.

O processo demonstrou a fragmentação das ações do Estado para atender às reivindicações dos movimentos populares, assim como o desfinanciamento de ações de natureza pública para projetos propostos por instituições de outras naturezas. Dessa maneira, nos centros urbanos, os movimentos avançavam tornando a manifestação popular nas ruas algo já ultrapassado, o que estimulava a busca de respostas imediatas para os problemas das classes populares por meio de propostas assistenciais. $\mathrm{Na}$ área rural o Movimento dos Sem-Terra ganhava força para se organizar e contrapor às mudanças ocorridas com o desmonte das políticas sociais pelo avanço das políticas neoliberais que levavam às mudanças no mundo do trabalho. Essas mudanças desorganizavam e flexibilizavam o mercado do trabalho levando ao crescimento do mercado de trabalho informal e, consequentemente, à perda de direitos sociais. A situação era agravada pela exigência de domínio de tecnologia aplicada à produção em face da globalização, para a qual o trabalhador não se encontrava preparado (Gohn, 2004).

Diante das mudanças, as entidades representativas dos movimentos sociais tiveram que se adaptar para captar recursos necessários para o desenvolvimento das ações. Para terem acesso aos financiamentos, tinham de seguir as diretrizes e regras estabelecidas pelos órgãos financiadores, os quais estabeleciam ações que deveriam ser direcionadas para atender grupos e questões considerados prioritários e relevantes. Os recursos públicos também passaram a ter novas políticas de financiamento e gestão, os projetos passaram a ser pontuais e focalizados, o que Gohn (2004) reconhece como processos que contribuíram para a desmobilização e desorganização das 
reivindicações dos movimentos sociais. Logo, as mobilizações populares passaram a desenvolver projetos que não tinham mais como princípio a autonomia e construção da cidadania. Nesse contexto, a autora reconhece que também foram desenvolvidos trabalhos e projetos que buscaram defender e desenvolver a cidadania e autonomia dos sujeitos atendidos. Eram projetos realizados por instituições com perfil democrático e participativo que tiveram pouco impacto na realidade, porque o processo participativo requeria envolvimento e compromisso dos participantes no desenvolvimento das ações e, assim, se tornava mais lento.

[...] A palavra de ordem destes projetos e programas passaram a ser propositivos e não apenas reivindicativo, ser ativo e não apenas um passivo reivindicante. [...] A atuação por projetos exige resultados e tem prazos. Criou-se uma nova gramática na qual mobilizar deixou de ser para o desenvolvimento de uma consciência crítica ou para protestar nas ruas. Mobilizar passou a ser sinônimo de arregimentar e organizar população para participar de programas e projetos sociais, a maioria dos quais já vinha totalmente pronta e atendia a pequenas parcelas da população. $O$ militante foi se transformando no ativista organizador das clientelas usuárias dos serviços sociais (Gohn, 2004, p.26).

Com o reconhecimento de tantas contradições, os movimentos passaram a viver conflitos e tensões e assim se questionou o exercício da representação nos espaços públicos - conselhos, conferências, comissões e programas governamentais, entre outros. Para agravar ainda mais a situação, alguns líderes de movimentos se candidataram ao parlamento, outros ascenderam a cargos públicos em diferentes esferas de governo, como também se teve continuísmo de mandatos de representantes e de delegados (Stotz, 2006; Gohn, 2004).

No início da década de 1990 Cortes (2002) identificou dois projetos conflitantes no setor saúde. Um deles, liderado pelo grupo que defendia a reforma do sistema brasileiro de saúde, com a expansão dos serviços públicos para acesso universal e aumento do controle estatal sobre os serviços privados. $\mathrm{O}$ outro projeto era liderado pelos liberais que defendiam o interesse dos serviços privados, os quais deveriam ser expandidos para as classes com poder aquisitivo mais elevado e os serviços públicos deveriam ser prestados 
somente para a classe mais pobre da população com financiamento de recursos públicos.

$\mathrm{Na}$ lógica de alinhamento às políticas neoliberais, em 1999 se regulamentou as Organizações Sociais o que, segundo Gohn (2004), atendia às novas propostas da reforma do Estado Brasileiro. Portanto, as Organizações Sociais (OSs) e as Organizações da Sociedade Civil de Interesse público (OSCIPs) passam a representar o novo perfil de entidade, o chamado Terceiro Setor - ONGs, associações comunitárias ou filantrópicas ou ainda as instituições consideradas como entidades sem fins lucrativos. No caso, o Estado passa a ser o promotor e regulador dos serviços e ações que têm a execução transferida para a responsabilidade das novas organizações sociais. Segundo a autora, a execução dos projetos com financiamento público pelas entidades que compõem o Terceiro Setor não tem o mesmo rigor que a administração direta. A avaliação fica a cargo dos conselhos gestores, que devem avaliar os resultados e as metas estabelecidos para os projetos aos quais a entidade se candidatou a desenvolver e para tal recebeu financiamento. Nesses conselhos sentam-se diferentes segmentos da sociedade: gestores de serviços públicos, movimento social organizado, prestadores de serviços contratados, representantes de técnicos por meio de suas associações e sindicatos, trabalhadores do setor, entre outros.

A contradição exposta permite refletir sobre o que de fato passa a ser a participação popular nos espaços públicos. Os membros dos conselhos gestores, responsáveis pela fiscalização do uso do dinheiro público derivado para instituições do Terceiro Setor, passaram a apreciar os processos, nas instâncias colegiadas, sem a visão crítica da realidade e as dimensões que a conformavam e assim tornaram-se meros reprodutores do desejo, já estabelecido, dos grupos dominantes, sem conseguirem imprimir nas Políticas Públicas diretrizes para o atendimento às demandas dos grupos e comunidades.

[...] se os atores participantes dos pactos e parcerias na esfera pública advirem de sujeitos políticos organizados nos espaços públicos da sociedade civil, com pouca representatividade, fracos laços de pertencimento social, projetos, valores e visões de mundo não cidadãos, voltados para coletivos organizados apenas como grupos de interesses, grupos de pressão ou grupos focais que atuam segundo regras exclusivas do mercado, seus resultados e impactos, não 
poderão esperar avanços na democratização das relações povogoverno e nem mudanças sociais significativas em direção a projetos emancipatórios, que contemplem a justiça, a igualdade etc. Esta forma de atuação tem como objetivo alterar, progressivamente, a subordinação (ou apatia) da sociedade civil frente ao Estado. [...] Ser representante das demandas e dos interesses da sociedade implica em realizar mediações e intermediações. Decisões políticas democráticas envolvem mudanças no campo estatal como da própria sociedade civil, desde que certos princípios democráticos não sejam abandonados, mas sejam marcos referenciais, quais sejam: justiça, liberdade, solidariedade e igualdade com respeito às diferenças (Gohn, 2004, p.29).

No Relatório Final da 11. ${ }^{a}$ Conferência Nacional de Saúde foram registradas as limitações da representação social no setor e as dificuldades dos gestores quanto à compreensão do papel dos conselheiros na definição das Políticas Públicas de saúde e no acompanhamento dos recursos financeiros do setor. O registro aponta a necessidade de serem ultrapassadas tantas dificuldades e, assim, garantir a autonomia dos movimentos sociais perante gestores, a legitimidade das representações e conquistas democráticas no setor (Brasil, 2000).

\subsubsection{A participação popular no Sistema Único de Saúde}

A luta pela democratização da saúde e a constituição da Saúde Coletiva como campo de saber e prática profissional foram fundados em bases teóricas, nas quais a determinação social da saúde da população estava relacionada à estrutura produtiva da sociedade (Fleury, 1997).

No movimento da Reforma Sanitária brasileira se buscou garantir a participação popular na organização e definição de diretrizes para o setor saúde princípio garantido no texto constitucional de 1988 (art.194, VII), diretriz do Sistema Único de Saúde, no qual se registra que a participação popular no setor deve ser por meio de representação em órgãos colegiados e deliberativos no sentido de fornecer subsídios que permitam o atendimento às necessidades da população. Atualmente os Conselhos e as Conferências de Saúde são espaços públicos legitimados para discutir as questões de 
saúde da população e, assim, influenciar na definição das Políticas Públicas de saúde (Brasil, 1988).

Ao resgatar historicamente a divisão dos enfoques preventivo coletivo e curativo individual, Cohn et al. (1999) reconhecem que a divisão teve início do século $X X$ e que com esta divisão o Estado tornou-se responsável pelo controle de endemias compreendidas como demanda do coletivo e a assistência médica individual sob a responsabilidade do seguro social. O direito à assistência médica foi vinculado à inserção do indivíduo no mercado de trabalho formal e, para financiar as ações destes serviços, os recursos vinham de contribuição compulsória do salário do empregado, percentual da renda das empresas e parcela da arrecadação do Estado deveria ser destinada para compor os recursos. Para cumprir com a responsabilidade de desenvolver medidas coletivas de saúde, o poder público utilizava parte da arrecadação orçamentária, e variava de acordo com o governante. Portanto, a regulamentação sobre o percentual da arrecadação a ser destinado ao setor não tinha definição em nenhum dos dois casos.

Valla (1992) afirma que falar em uso de ações dos serviços básicos pela população é fazer referência aos serviços que estão sob responsabilidade do Estado, financiados por verbas públicas e consumidos no coletivo para se ter o benefício da renovação das forças dos indivíduos para o trabalho e para a vida com qualidade. No Brasil o acesso a estes serviços não se dá por igual, embora toda a população pague por eles, ou seja, para o autor esta questão está relacionada ao desenvolvimento da cidadania. Neste caso, reconhece que na sociedade brasileira a cidadania é a "cidadania da sobrevivência" ou "cidadania da escassez", mais do que o exercício pleno da cidadania, pois a população não conta com serviços públicos de saúde que Ihe permita garantir qualidade na reprodução da sua força de trabalho. Ao contrário, afirma que historicamente as verbas públicas brasileiras têm sido majoritariamente alocadas para garantir Políticas Públicas que atendam as demandas da produção e reprodução do capital.

Na lógica de funcionamento ineficiente os serviços de saúde responsabilizavam os indivíduos pela não adesão às orientações e, consequentemente, por seus problemas de saúde. Portanto, a culpa pelo adoecimento ficou 
relacionada ao conhecimento insuficiente que indivíduos de classes subalternas detinham para promover as mudanças em suas realidades, contrariando as orientações científicas disponibilizadas pelos técnicos do setor, os quais Valla (1992) denominou 'mediadores da classe média'. A terminologia foi empregada pela postura do técnico do setor ao reproduzir o saber da classe hegemônica e, ao mesmo tempo, por não ser capaz de reconhecer as necessidades dos usuários dos serviços.

As relações entre serviços de saúde e comunidades eram no sentido aproximar os indivíduos ao discurso sanitário para difundi-lo junto a grupos populares e, assim, promover a adesão às orientações e ações de autocuidado e de higiene - individual e coletiva. O redirecionamento das políticas e práticas do setor saúde no Brasil, no sentido de garantir o atendimento às demandas e necessidades da população, teve início na década de 1970, juntamente com o movimento da América Latina (Carvalho, 1995).

$\mathrm{Na}$ época, os movimentos sociais organizados reivindicavam que seus representantes participassem da elaboração das Políticas Públicas do setor, principalmente nos grandes centros urbanos. As questões centrais na discussão estavam relacionadas à dificuldade de acesso aos serviços de saúde e ao modelo de assistência inadequado para atender às demandas das populações mais pobres moradoras de áreas periféricas de grandes centros, tal como São Paulo. A reivindicação contou com o apoio de movimentos religiosos, partidos políticos e técnicos da saúde, defensores da mudança do modelo de atenção à saúde, que era centrado na doença e com ações curativas desenvolvidas nos hospitais. As propostas para a reorganização dos serviços de saúde tinham o objetivo de integrar, reestruturar, hierarquizar e regionalizar tais serviços em um espaço territorial definido, segundo os princípios da igualdade, universalidade, integralidade e acessibilidade. Estabelecer o financiamento do setor era outra questão urgente e importante, pois além da indefinição sobre o percentual da arrecadação tributária a ser destinado ao setor, havia a centralização do uso dos recursos nas ações curativas em detrimento das ações da atenção básica à saúde. Portanto, nos movimentos se discutia a necessidade da racionalidade na oferta de serviços, assim 
como da capacidade instaladas nestes para solucionar as questões de saúde dos usuários (Cohn et al., 1999).

É nesse sentido que a regulamentação sobre a participação popular no Sistema Único de Saúde prevista na Constituição Federal e na Lei n. ${ }^{\circ}$ 8.080/90, por meio da Lei $n .^{\circ} 8.142 / 90$, é considerado um avanço significativo ao garantir instâncias colegiadas para a participação do movimento social organizado no SUS. Os Conselhos de Saúde são instâncias permanentes de deliberação e as Conferências convocadas em períodos regulares, em cada esfera de governo, para consulta à sociedade sobre as demandas e necessidades em saúde no sentido de definir as diretrizes para as Políticas Públicas do setor (Carvalho; Santos, 1992).

Escorel (2008) aponta que esses mecanismos de participação não são diretos, mas sim de democracia representativa, que conforma o conjunto de órgão colegiado e deliberativo para a definição das Políticas Públicas para o setor, porém, por ser um processo recente, apenas 20 anos, necessita ser expandido e aprofundado. Labra (2008, p.108-9), ao discutir a representação popular nos Conselhos de Saúde, afirma:

[...] um aspecto pouco explorado na literatura sobre conselhos tem a ver com a dimensão associativa e fatores a que esta envolve, como a natureza, objetivos e abrangência das organizações representadas nessas instâncias, de um lado, e a relação entre estas e seus representantes nos conselhos, de outro. Nessas conexões, a questão da representação é crucial para o entendimento cabal do desempenho dos conselheiros representantes dos usuários, em particular no que tange às suas possibilidades de exercício do controle social. [...] A respeito da qualidade desse desempenho, as seguintes hipóteses de trabalho podem ser enunciadas: (a) quanto mais apoio de sua associação o conselheiro receber de sua associação, melhor será seu desempenho; (b) um desempenho bom significa influir nas resoluções do colegiado em favor de medidas de interesse geral; (c) o bom desempenho dos conselheiros e a capacidade de influir em decisões voltadas para o bem-comum são necessárias para o exercício do controle social.

Carvalho (1997) afirma que as idéias e práticas que levaram a constituição do Conselho de Saúde tiveram sua base na luta do movimento social organizado, nesse caso advindos das classes mais pobres, contra o Estado repressor representante dos interesses da elite da sociedade capitalista. A conquista do espaço institucional para o controle social foi possível a partir 
da pressão dos movimentos sociais que combatiam as práticas de interesses privados excludentes, intrínsecas nas Políticas Públicas, logo no próprio Estado. Assim, aos Conselhos caberia a tarefa de reverter tal situação sendo guardiães em defesa dos princípios e da agenda da Reforma Sanitária com atuação dentro do Estado e, ao mesmo tempo, em posição externa a ele. Para o autor, tal situação gerava expectativas ambíguas, ilusão e ceticismo, no exercício dos Conselhos:

\begin{abstract}
A ilusão [...] consiste na superestimação da margem de efetividade dos Conselhos como arenas decisórias. Alimenta-se da miragem de um Estado neutro, passível de ser conduzido pelos segmentos que obtenham vantagens circunstanciais nos espaços decisórios. [...] a sociedade, suficientemente organizada e representada [...] poderia controlar o Estado, conduzindo-o segundo seus desígnios. Como se, a partir do mero funcionamento regular dos Conselhos, do cumprimento de suas prerrogativas legais, o Estado se "corrigise" e passasse a funcionar segundo os interesses da maioria. Embora tal imagem possa favorecer o proselitismo participatório, atraindo segmentos sociais ansiosos por colocar suas demandas junto ao aparelho estatal, até então impermeável a elas, na verdade, ela se mostra insuficiente para dar sustentação ao funcionamento estável dos Conselhos. Diante da inefetividade desses órgãos em satisfazer as demandas finalísticas a elas submetidas, os representantes de segmentos podem reduzir suas expectativas, gerando esvaziamento [...] uma adaptação conformada a seus limites como arenas decisórias [...] O ceticismo [...] tende a subestimar as possibilidades de autonomia e efetividade dos Conselhos. É curioso que a configuração jurídico-institucional desses órgãos, cuja composição discrimina positivamente setores sociais com menos acesso ao poder (caráter paritário) e enfatiza sua responsabilidade decisória (poderes deliberativos), tenha se originado exatamente na desconfiança de que o Estado pudesse ser passível de influência a ponto de implementar as medidas redistribuitivas demandadas pelos setores excluídos e agora representados [...] essa desconfiança pode paradoxalmente provocar um rebaixamento ou "atraso" nas práticas dos Conselhos, reduzindo-as a uma dimensão meramente fiscalizatória, onde a obsessão com o controle burocrático de processos termina por fazer negligenciar a preocupação com os resultados, elo mais importante de ligação dos Conselhos com a sociedade representada, sobretudo os setores excluídos (Carvalho, 1997, p.97-8, grifo nosso).
\end{abstract}

Somada à responsabilidade de participar no processo de formulação das políticas de saúde, o Conselho tem também a atribuição de acompanhar a execução delas, assim como acompanhar todos os aspectos financeiros relacionados a esta execução e, por fim, verificar a efetividade das intervenções sobre os problemas de saúde da população. Para dar conta de tais atribuições, 
- Conselho deve promover reuniões ordinárias periódicas, de caráter deliberativo, com a participação dos representantes dos segmentos que o compõem: entidades da sociedade civil (50\% das vagas), trabalhadores da saúde, prestadores de serviços e gestores (os outros $50 \%$ das vagas). $\mathrm{Na}$ atuação do Conselho, segundo Moreira e Escorel (2009, p.798), há o reconhecimento do Estado como "[...] arena de articulação e embate político entre os diferentes interesses que disputam espaço e poder [...]." E é nesse processo de participação e decisão que há a disputa interna para a ocupação dos espaços, concretizado nos seus plenários, o processo de disputa externo, no qual o próprio Conselho disputa com outras instituições a definição das Políticas Públicas de saúde.

[...] Os CMS que têm melhores condições de autonomia e organização são também os que se localizam em municípios que apresentam uma sociedade mais mobilizada e acostumada à negociação e à articulação política. No setor saúde [...] são os que apresentam a maior quantidade de conselhos locais de saúde e de conselhos gestores de unidade de saúde (Moreira; Escorel, 2009, p.804).

As Conferências de Saúde são momentos de consulta ampla à sociedade, convocados com antecedência, promovem amplo debate sobre as necessidades em saúde e, ainda, discutem como a população gostaria que suas necessidades fossem atendidas nas diferentes esferas de governo. Com os resultados desta consulta que ocorre com a aprovação das propostas pelos delegados no plenário, sendo que os delegados são representantes de diferentes segmentos da sociedade organizada eleitos para tal, os gestores organizam os serviços de saúde sob sua responsabilidade.

[...] As Conferências delineiam a política de saúde a ser desenvolvida pelos gestores [...]. Os participantes, em primeira análise, deveriam ser todos os cidadãos; entretanto isso se tornaria impraticável. Daí a proposta mais comumente aceita de que das Conferências participem apenas os delegados dos vários estratos sociais e dos grupos envolvidos na questão saúde: usuários, prestadores de serviços (incluindo trabalhadores de saúde) e administradores públicos. A proporcionalidade adotada entre delegados é a mesma adotada nos Conselhos de Saúde: paridade entre usuários e os demais componentes [...] O princípio da participação é ascendente [...] as Conferências Municipais deveriam brotar de conferências [...] locais, regionais, que culminariam nas municipais. As municipais levariam seus delegados às estaduais e as estaduais enviariam os 
delegados à nacional. Este movimento ascendente, provindo da base, daria chance à maior legitimação da representatividade dos diversos seguimentos sociais, fazendo com que cada delegado realmente representasse, por suas teses e voto, um conjunto de cidadãos (Carvalho; Santos, 1992, p.263).

\subsubsection{A consolidação da democracia no setor saúde}

Para Moreira e Escorel (2009), o processo de participação nos Conselhos Municipais de Saúde, no sentido de efetivar um processo decisório democrático no setor, só será legitimo e com resultados positivos para a sociedade se os agentes ligados ao interesse dos problemas públicos atuarem no sentido de garantir a autonomia e organização do Conselho, contrariando grupos que consideram a participação popular um problema para seus interesses.

Considerando as limitações e contradições apontadas na revisão teórica apresentada, há que se pensar sobre a contribuição do setor saúde para a definição de Políticas Públicas no sentido de se construir uma sociedade democrática com práticas inclusivas, ou seja, busca-se que as diferentes classes sociais sejam contempladas pelos serviços prestados pelo Estado, assim como toda a diversidade de etnia e gênero presentes nela. Nesse sentido, Cortes (2002) afirma que os Conselhos e Conferências de Saúde expõem as necessidades em saúde da população e, assim, influenciam as Políticas Públicas do setor no sentido de atendê-las, mas considera que este é um processo em construção, pois percebe que os serviços de saúde ainda não têm condições para desenvolver intervenções que contemplem o modelo proposto pelo movimento da Reforma Sanitária. Nesse sentido, o modelo de intervenção para atender às necessidades em saúde só será possível por meio da ampliação da participação popular para influir cada vez mais na formulação de Políticas Públicas e na fiscalização dos recursos públicos destinados ao setor.

Acrescenta-se ao pensamento dos autores citados que as perspectivas de avanço estão relacionadas às discussões sobre as políticas econômicas 
e sociais como determinação social do processo saúde-doença nesses fóruns. E que nas discussões sobre a realidade de saúde e das políticas que irão definir as intervenções do setor sejam problematizadas nas diferentes dimensões da realidade que conformam as necessidades em saúde: estrutural, particular e singular. E que neste movimento de participação, construção tão recente, tem que haver o cuidado para não retornar a concepção sobre os problemas sociais como coisas do Estado, a serem resolvidos segundo as vontades dos governantes. Ao contrário, que os problemas sociais sejam questões para se decidir com Políticas Públicas inclusivas e protetoras que tenham sido discutidas com os movimentos legítimos da sociedade.

Por fim, a perspectiva de se constituir a representação social efetiva está relacionada às propostas de formação de conselheiros com base teórica para desenvolver o pensamento crítico-reflexivo sobre a determinação social do processo saúde-doença. O objetivo deve ser instrumentalizar os líderes do movimento social organizado para o exercício de suas representações nos diferentes espaços instituídos. Este referencial permitiria aos conselheiros escolher a intervenção em saúde mais adequada no sentido de transformar realidades de saúde indesejadas por indivíduos e comunidades.

\subsection{COMPETÊNCIAS}

Para Ramos (2002), o modelo de competência exige tornar a organização mais flexível, mais aberta. Nessa deve-se considerar as relações entre as variáveis próprias dos diversos procedimentos necessários para os resultados desejados e, também, as variáveis relacionadas às personalidades e relações interpessoais dos trabalhadores no processo de produção. Zarifian (2003, p.75) afirma que "[...] o desafio da competência é a volta do trabalho para o trabalhador [...]"(grifo do autor), pois esse modelo se contrapõe ao modelo taylorista que nos últimos anos tornou o trabalho humano fragmentado, repetitivo e alienado para o próprio trabalhador que não concebia o projeto que executava. 
No modelo de competência a qualificação do trabalhador é por meio da mobilização do conhecimento técnico da própria formação e dos atributos subjetivos do trabalhador ao enfrentar situações não previstas no trabalho. Pressupõe-se que é na experiência que o sujeito construiria os novos saberes necessários para o desenvolvimento de ações comprometidas com o resultado.

Ao indagar e analisar se esse novo modelo leva a autonomia ou à adaptação dos sujeitos, Ramos (2002) refere que esse aspecto, a aprendizagem pela experiência, deve ser considerado com cuidado, visto que a superação dos saberes na execução de ações no trabalho deveria ser por meio de educação profissional contínua, pois formalizaria conhecimentos técnicos necessários ao exercício da profissão. Chama a atenção também para a construção história dos saberes na constituição do modelo das profissões, na sociedade, ao longo dos anos.

A autora alerta para essa questão visto que colocar a qualificação, ou seja, a construção do conhecimento, pela experiência no trabalho é, consequentemente, negar ao trabalhador a sua possibilidade de empregabilidade e enfraquecer a dimensão social da sua própria qualificação, pois afirma que a ordenação das relações de trabalhos e as relações educativas são socialmente construídas e garantem às pessoas condições para que vivam do seu trabalho. Ao contrário, haveria uma tendência de se configurar um profissionalismo de tipo liberal que significa valorizar a adaptação do indivíduo às mudanças socioeconômicas do capitalismo tardio, e, assim, individualmente os sujeitos buscariam maneiras de responder a essas mudanças para se construírem, com estratégias e respostas próprias, no sentido de enfrentar os desafios no trabalho.

Logo, a individualização e a valorização do singular em detrimento da construção social, na esfera do trabalho e da educação, têm de ser vistas com muito cuidado e critério. A propagação dessa idéia para Tanguy (1997), acontece justamente no momento em que a qualificação de jovens diplomados, tanto no ensino médio como no superior, já não basta para diferenciar os sujeitos para o trabalho. Para esses sujeitos, coloca-se a necessidade de mobilizar seus conhecimentos em determinadas situações para estabelecer as 
diferenças entre si. Neste caso, os aspectos subjetivos para a mobilização do conhecimento e ação em determinadas situações serão a maneira de construir novos saberes para o mundo do trabalho, o que refletirá na educação de novos sujeitos. Para os autores, os fenômenos que ocorrerão na emergência do modelo de competência devem ser acompanhados continuamente pela psicologia e ciências sociais no sentido de compreender as consequências desse modelo no mundo da educação e do trabalho.

[...] A valorização das competências individuais dos trabalhadores inscreve-se, portanto, no marco de um individualismo liberal e de subjetividades atomizadas. E se a escola deve voltar-se para o desenvolvimento dessas competências, perde importância sua participação, assim como de todos os elementos culturais, na formação da consciência de classe e na construção de mundo (Ramos, 2002, p.303).

A emergência do modelo de competência é dividida em quatro momentos para Zarifian (2003). O primeiro momento, início dos anos 1970 , período marcado pela crise econômica que tinha prioridades estabelecidas para a reorganização das indústrias no sentido de discutir sobre as reestruturações e redesenvovimento. $O$ início do modelo de competência é identificado pelo acordo conturbado entre os trabalhadores e as indústrias da metalurgia. Ficou estabelecido que eram necessários critérios para os empregos: responsabilidade, autonomia e exigência de formação. Assim, os empregos deixariam de ser altamente normativos, ao contrário, a complexidade de tarefas exigidas deveriam ser enfrentada com autonomia, responsabilidade e conhecimentos advindos da formação. $O$ autor reconhece que os novos critérios significavam uma vitória para os trabalhadores contra o modelo taylorista ao qual estavam submetidos há muito tempo.

No segundo momento, no início dos anos 1980, marcado pela crise de alguns setores da economia, foi debatido sobre o modelo de produção que passava a empregar mais tecnologia na produção, os trabalhadores tinham que executar tarefas mais complexas e abstratas em menor tempo e, ainda, a preocupação com a qualidade do produto para um mercado que se tornava mais competitivo globalizado e com ritmo rápido para a reposição de produto. Foi nesse mesmo período, segundo Benjamin Coriat apud Zarifian 
(2003), que os métodos japoneses, propostos para as indústrias, colocaram a demanda como sendo central na lógica da organização do processo de produção. Era necessário produzir para atender às especificidades e exigências da clientela. O autor identifica que naquele momento se acrescentou ao modelo de competência a responsabilização do trabalhador sobre o produto do seu trabalho, pois foi delegado aos trabalhadores das equipes, chamadas de "equipes de base", responder por seu desempenho para atender ao objetivo da produção.

Acrescidas às questões já expostas, Zarifian (2003) refere que este período também é reconhecido como sendo o início da precarização das relações de trabalho. Em meados dos anos de 1980 aumentaram as relações precárias de trabalho. Destaca-se que a contratação de trabalhadores passou a ser para execução de tarefas específicas por empresas terceirizadas. Este fenômeno foi na contramão do modelo de competência, pois o trabalhador temporário precisaria de mais prescrições para desenvolver as tarefas e que o mesmo não se comprometeria por um trabalho que não sabia por quanto tempo iria permanecer, e o descompromisso também seria com o produto deste trabalho. Acrescentam-se a essas afirmações os fenômenos que se observaram com relação às relações precárias de contratação para o trabalho no Brasil ao longo dos últimos anos. Sem domínio de especificidades das técnicas de segurança, muitos dos trabalhadores temporários ou terceirizados se acidentaram ou provocaram acidentes gravíssimos em atividades de alta periculosidade. Em alguns desses casos o preço pago foi a própria vida.

O terceiro período, iniciado nos anos 1990, foi reconhecido como um período penoso sem grandes avanços no modelo de competência. Ao contrário, Zarifian (2003) destaca o período como sendo o pior para o modelo de competências. Refere que ocorreram desmobilizações das equipes que implantavam o modelo, as empresas passam a focar o aumento da rentabilidade, logo foram adotados planos para redução de custos. Dessa forma, o desenvolvimento do modelo de competências serviu apenas para um reduzido número de trabalhadores que se manteve. Para o autor, esse foi o momento no qual o modelo de competência estava ocultado, mas não estava morto. 
O quarto momento correspondente ao final dos anos 1990 quando emergiram novamente discussões sobre a temática, pois, nessa fase, se compreendeu que as tecnologias aplicadas na produção, as estruturas organizacionais e os níveis salariais não eram suficientes para a competição capitalista em um forte mercado concorrencial. Precisava-se de nova definição de produtividade. Assim, a produção para atender a um mercado globalizado e competitivo impunha modificações nos produtos e logicamente no seu processo de produção. A discussão sobre a necessidade de mudanças no trabalho e na formação para este passou a ser articulada em diversos cenários, entre estes se destacaram as pesquisas acadêmicas (Zarifian, 2003).

As gerências e os responsáveis por recursos humanos ponderavam sobre a forma de avaliação dos trabalhadores nas seleções para os postos de trabalhos e na avaliação dos desempenhos dos trabalhadores no cumprimento das tarefas determinadas. Portanto, a questão era remetida para os requisitos preconizados nos processos de recrutamento e de avaliação de desempenho. Nos processos até então desenvolvidos eram verificadas basicamente a habilidade e destreza do sujeito para a execução de tarefas nos postos de trabalhos. "[...] no industrialismo, o indivíduo é desapossado de sua atividade produtiva, que the é devolvida como forma exterior (o trabalho, as tarefas atribuídas ao posto), à qual ele deve submeter-se [...]" (Zarifian, 2003, p.77).

As indústrias que adotavam o modelo taylorista nos seus processos de produção tinham as maiores dificuldades, uma vez que precisavam reverter a lógica de inserção do trabalhador na produção. Essa dificuldade originou a crise, segundo Zarifian (2003), porque o mercado consumidor pedia flexibilidade na produção que atendesse às demandas dos clientes.

As mudanças tecnológicas e de organização do trabalho por que passam os países de capitalismo avançado a partir dos meados da década de 80 configuram o mundo produtivo com algumas características tendenciais: flexibilização da produção e reestruturação das ocupações; integração de setores da produção; multifuncionalidade e polivalência dos trabalhadores não ligado ao trabalho prescrito ou ao conhecimento formalizado (Ramos, 2002, p.37-8).

A crítica que se fazia ao processo de trabalho fundamentado no modelo taylorista era que este não estimulava o trabalhador a participar das 
oscilações vividas pela empresa, ao contrário, estimulava-o a cumprir tarefas, ordens e normas sem que percebesse o todo no qual estava imerso o seu trabalho. A empresa, ao adotar este modelo de organização do processo de produção, estimulava a alienação do trabalhador do processo de produção como um todo e ainda a se aperfeiçoar para cumprir tarefas específicas do seu posto de trabalho. Logo, com um cenário econômico conturbado e exigente de produtos de qualidade para satisfazer os clientes, emergiu a necessidade de se comprometer os trabalhadores com tais mudanças. Para tal, o trabalhador precisava ter autonomia, responsabilidade e atitudes para o enfrentamento das mudanças. Para que estes critérios se estabelecessem no trabalho a empresa deveria diminuir as normas e as rotinas. Tais mudanças representavam uma significativa alteração na organização do trabalho, assim como na qualificação deste sujeito para o trabalho.

[...] a diminuição das normas se torna algo benéfico, o que mostra, indiretamente, que os empregos com muitas normas são, se não um mal, pelo ao menos uma situação pouco desejada e valorizada. Devemos ressaltar este fato: os critérios de autonomia e responsabilidade são completamente novos em relação ao critério clássico de complexidade da atividade. Sempre se valorizou o fato de ocupar-se um emprego complexo, mas isso podia acontecer "com muitas normas e pouca responsabilidade". O taylorismo nunca foi sinônimo de empregos simples e pouco qualificados [...] (Zarifian, 2003, p.52).

Para Ramos, o que ocorreu nesse período não foi uma substituição, mas uma nova estratégia de ordenar a relação do trabalho-educação. A autora destaca que a noção de competência implica reconfigurar o conceito de profissionalização em várias dimensões. Na dimensão econômica identifica que é para preparar os indivíduos "[...] para viverem com o produto do seu trabalho [...]"; na dimensão sociológica é "[...] desenvolver uma identidade sócioprofissional [...]"; na dimensão ético-política é "[...] promover a interio-rização do conjunto de regras e valores que instalam o ato profissional [...]" (p.283). 
A institucionalização da noção de competência permitiu-nos concluir que, metodologicamente, os processos de trabalho têm sido analisados segundo a teoria funcionalista. Esse aporte metodológico é coerente com a concepção natural-funcionalista de homem e uma concepção subjetivo-relativista de conhecimento, que reforçaria o irracionalismo pós-moderno (Ramos, 2002, p.284).

As mudanças, as quais ocorrem no mundo do trabalho, baseiam-se na flexibilização do próprio trabalho, que não se limitou à dimensão técnicainstrumental. Entretanto, esta mudança também é intelectual com as exigências para a tarefa cotidiana que serão infinitamente mais vastas. $O$ trabalhador passou a ser multiqualificado para exercer funções abstratas e executar cada vez menos as tarefas manuais (Witt, 2005).

Para Ramos (2002), é importante perceber as mudanças que ocorreram nas ocupações e as exigências de polivalência para os trabalhadores. $\mathrm{Na}$ lógica do modelo de competência, Zarifian (2001, p.42) afirma que a "[...] competência profissional consiste em fazer frente a eventos de maneira pertinente e com conhecimento de causa [...]" e diante do evento o trabalhador automobiliza sua competência para enfrentar as situações reais, sendo que a competência é uma propriedade particular do trabalhador e não de um posto de trabalho.

Considera, ainda, que as condições organizacionais que permitiriam ao sujeito desenvolver as ações necessárias precedem a tomada de iniciativa e de responsabilidade. Para tal, seria necessário que o trabalhador se mantivesse atento às modificações do ambiente, organizasse suas ações no sentido de procurar respostas para os eventos e conduzisse as ações, uma vez que deve estar preparado para analisar diferentes alternativas para enfrentamento do evento sem criar procedimentos engessados ou padronizados a priori.

[...] os eventos provocam perturbação, agitação. O trabalho não pode mais ser visto como uma seqüência de operações programadas, "rotinizadas", repetíveis. Torna-se uma seqüência de eventos de situações singulares que se entrechocam, que reagem umas às outras em um regime de modificação [...] (Zarifian, 2001, p.43).

Os eventos têm origem em situações profissionais e é nelas que o trabalhador desenvolverá suas experiências as quais lhe permitirão um 
movimento de ida e volta de conhecimentos, que devem ser mobilizados para organizar a forma de enfrentá-las sem a preocupação de preestabelecer regras de ação. Zarifian (2001) afirma que aprendizagem que nasce da experiência pode ser por meio de conhecimentos estabelecidos em situações reais ou virtuais, pois ambas permitem aos sujeitos relacionar causas, efeitos e técnicas que podem ser empregadas para o enfrentamento de eventos. Porém, destaca que os conhecimentos adquiridos e muitas vezes testados não podem ser imobilizadores, ao contrário, devem permitir a sua superação uma vez que a cada fenômeno enfrentado o trabalhador deve procurar entender quais foram suas determinações. Para Ramos (2002), esta é uma questão central para a crítica ao modelo de competência - a construção do conhecimento pela experiência.

A autora afirma que a construção de conhecimentos pela experiência ocorre por questões anteriores que necessariamente devem ser discutidas. Entre as questões antecedentes destaca que o trabalho na sociedade capitalista historicamente possibilita experiências diferentes para indivíduos de acordo com a sua classe social. Afirma que na construção do conhecimento não se pode impossibilitar o sujeito de conhecer a totalidade da realidade, ou seja, as suas determinações e contradições. Ao contrário, o indivíduo que é levado a compreender que a realidade é aquela que é possível de ver segundo o seu ponto de vista e a partir deste conhecimento generaliza e universaliza "verdades", está sendo adaptado e não é levado a buscar sua autonomia. $\mathrm{O}$ sujeito necessita aprender que a realidade objetiva se apreende por meio da aparência e não da essência do fenômeno.

Qualquer objeto que o homem possa perceber ou criar é parte de um todo. Em cada ação empreendida, o ser humano se defronta, inevitavelmente, com problemas interligados. Por isso, para encaminhar uma solução para os problemas, o ser humano precisa ter uma certa visão de conjunto deles: é a partir da visão de conjunto que a gente pode avaliar a dimensão de cada elemento do quadro.[...] se não enxergarmos o todo, podemos atribuir um valor exagerado a uma verdade limitada (transformando-a em mentira), prejudicando a nossa compreensão de uma verdade mais geral (Konder, 1981, p.36, grifo do autor). 
A captação do fenômeno como parte do todo se dá por meio do pensamento abstrato, que é uma forma de conhecer a realidade com mais aprofundamento, pois o que lhe está oculto está além da experiência, do contato, da aparência ou da visão imediata que se tem. No pensamento abstrato buscam-se o oculto, as contradições e as determinações que o conformam como realidade objetiva e, nesse caso, não são compreendidas pela experiência. Ramos (2002) afirma que ao compreender a realidade material histórica e social o indivíduo tem a possibilidade de dominá-la e transformá-la.

[...] pela concepção histórico-social de homem, compreende-se que a formação humana se processa pela produção material da existência numa relação dialética entre objetivação e apropriação. Isto é, ao agir sobre a natureza produzindo meios adequados à satisfação de suas necessidades, o homem se objetiva em sua produção. Essa transformação objetiva requer dele uma transformação também subjetiva. A realidade torna-se uma realidade humanizada objetivamente e subjetivamente. A realidade objetivada pelo homem é historicamente apropriada por outros homens com o sentido de reproduzir continuamente as funções humanas (Ramos, 2002, p.297).

No pensamento materialista histórico e dialético compreende-se que o trabalho permitiu ao ser humano ir além da natureza, contrapondo-se como sujeito no mundo, pois estabelece a relação sujeito-objeto. Para os pensadores desta linha filosófica, Hegel, Marx, Engels, o trabalho permite ao indivíduo produzir-se a si mesmo ao mesmo tempo em que produz o objeto. Konder (1981, p.26) afirma que "[...] O trabalho é o conceito-chave para nós compreendermos o que é superação dialética [...]". Citando Hegel, o autor afirma que "superação dialética" é simultaneamente a negação de uma determinada realidade com a conservação de algo essencial que nela existe e é negado ao ser elevada a um nível superior. $O$ autor toma como exemplo a transformação da matéria-prima, que é "negada" ao mesmo tempo em que é "conservada" para ser transformada em um objeto segundo os objetivos humanos, ou seja, é "elevada" em seu valor. Pode-se perceber esse movimento na madeira que é transformada em cadeiras e mesas por meio do trabalho do humano aplicado na matéria-prima. Por meio do trabalho o indivíduo tem a possibilidade de transformar a natureza e ao mesmo tempo 
se transformar. Logo, a superação da realidade é encontrada na relação, homem-trabalho-natureza.

O trabalho industrial é para Zarifian (2003) uma criação que transforma o trabalho em objeto, pois ele pode ser transformado independentemente daquele que o realiza. No industrialismo tornam-se objetos o "trabalho" e o "trabalhador". Este último por ser considerado um objeto que é portador de capacidades para a realização do trabalho. Assim, a qualificação do trabalhador passou a ser "[...] uma maneira de qualificar a relação mantida entre o trabalho objetivado e as capacidades do trabalhador a ele relacionadas, hierarquizando por níveis de complexidade [...]" (p.76). Para o autor, esta é a base para a organização dos "postos de trabalho". O posto de trabalho é compreendido como algo externo ao trabalhador que se cristaliza na relação deste com as tarefas a serem realizadas, no ritmo, no tempo e nos espaços determinados pela organização. Nesse caso, o indivíduo é destituído do uso de sua iniciativa e criatividade para a execução das atividades.

A mudança que propõe o modelo de competência para o trabalho será de longo prazo representando um novo período histórico. O desafio posto para o trabalhador, assim como para as organizações industriais e empresariais, por esta mudança é significativo uma vez que este veio para substituir modelos que até então foram dominantes: o modelo do posto de trabalho e o modelo da profissão que historicamente vêm se desenvolvendo há mais de dois séculos, sendo que o primeiro teve um desenvolvimento muito mais significativo pela organização do processo de produção que se baseou no taylorismo. Logo, mudar é um grande desafio para os envolvidos (Zarifian, 2003).

Os modelos citados acima até hoje convivem nos trabalhos que se tem no mundo, pois o modelo da profissão, em suas especificidades, regulamenta saberes, formações e formas de atuação técnica em diferentes espaços nos quais se encontram os profissionais. O modelo do posto de trabalho não negou o modelo da profissão, mas acabou por ser mais desenvolvido em processos de produção que tiveram avanço na divisão social do trabalho. Pelo posto de trabalho houve a inserção de não profissionais, ou seja, trabalhadores sem formações anteriores que desenvolviam atividades 
normatizadas e supervisionadas por pessoas com qualificação profissional em posições superiores às suas, normalmente profissionais com escolaridade universitária. Nesse caso, atendendo às lógicas colocadas pelo modelo econômico capitalista, no qual a produção em massa e o lucro eram premissas que se impunham à forma de organização da produção. Assim, ao longo dos anos os modelos conviveram e se complementaram para atender à produção em larga escala, com vistas a manter a lucratividade da produção.

Entretanto, no desenvolvimento dos novos modelos de produção para atender ao mercado de consumo em um mundo globalizado, foram introduzidas tecnologias nos processos de produção para que assim se tornassem mais dinâmicos. A crítica sobre a formação de trabalhadores apontava que esta atendia aos modelos de produção que estavam sendo superados e, portanto, também necessitava ser modificada.

Ao contrário, a noção de competência emergiria dos novos modelos de produção, sendo afeta à dinamicidade e à transformação. Neste sentido, a qualificação e as categorias que Ihe são associadas sofreriam um feroz ataque, tendendo a ser substituídas pela noção de competência. Esta visão parece ser compartilhada pelos empresários europeus e grupos envolvidos com as reestruturações administrativas, valendo-se dela para defender mudanças significativas na arquitetura social em que estão em jogo a formação, o controle do trabalho e as negociações coletivas de carreira e salário (Ramos, 2002, p.60).

Para Zarifian (2003) e Ramos (2002), os modelos de qualificação e competência se complementam, uma vez que a qualificação é necessária para a aproximação com os conhecimentos utilizados no trabalho e a competência é a maneira como este indivíduo utilizaria estes conhecimentos juntamente com as outras dimensões do saber para enfrentar os eventos no próprio trabalho. Os autores consideram o modelo de competências como o retorno à elaboração das idéias, por meio do pensamento crítico, para a ação do sujeito no trabalho.

Entretanto, Ramos (2002) alerta que a base do modelo de competência é convergente à lógica do pensamento pós-moderno na qual o individualismo se sobrepõe aos interesses e a construção de uma sociedade que toma o coletivo como princípio. Logo, nega-se a identidade social em nome da ética individual, e assim a sociedade e os sujeitos coletivos podem ser negados 
por um indivíduo que se encerra em si mesmo. Ao contrário, a autora afirma que nos espaços coletivos o sujeito tem a possibilidade de se desenvolver plenamente, de definir seus valores, sua personalidade e a ética de sua existência. Esse processo de desenvolvimento individual ocorre ao mesmo tempo em que se constroem as vontades coletivas por meio de um projeto de sociedade política e ética.

\subsubsection{Educação e competência}

Faustino (2004) destaca a necessidade de diferenciação dos termos habilidades e competências devido à grande confusão que se encontram nos referenciais que utilizam as terminologias. Para a autora, habilidade natural ou adquirida deve ser acrescida de outros recursos para o desenvolvimento das competências. Para desenvolver cada competência, o indivíduo necessitaria de um conjunto de habilidades, conhecimentos e atitudes.

Para Le Bortef (2003) apud Faustino (2004), a distinção é entre saberes, habilidades e competências. Os saberes seriam o conjunto de recursos já incorporados aos sujeitos ou aos recursos do meio. Assim, refere que as habilidades relacionam-se ao saber-fazer e as competências ao saber agir, destacando que este saber é ir além do que foi prescrito. Logo, segundo os autores referidos, competência pode ser compreendida como a capacidade de o sujeito mobilizar os diferentes recursos disponíveis para agir em uma determinada situação da vida. Os saberes são de diferentes dimensões: saber agir e reagir com pertinência; saber combinar recursos e mobilizá-los em um contexto; saber transpor; saber aprender, aprender a aprender e, por fim, saber envolver-se. Os saberes no mundo do trabalho são diferentes, sendo reconhecidos como: saber-fazer que se refere às habilidades, saber-ser que se refere às atitudes e na combinação e mobilização desses saberes, em um determinado contexto profissional, o indivíduo evidencia a sua competência. 
Para Witt (2005, p.64), a preocupação que se coloca com o novo modelo é que:

[...] o diploma deixa de ser o único ou principal pressuposto para o emprego e passa a concorrer com as formações ditas qualificantes, que visam à adaptação ao emprego. A escolaridade e a formação transformam-se, na verdade, numa aposta incerta, em que as perspectivas de emprego dependem, exclusivamente, de atributos individuais.

É a crise do modelo de produção que destitui a relação direta que se tinha de formação-emprego. Durante anos a busca de saberes específicos para o domínio de um determinado conjunto de conhecimentos é reconhecido no avanço das qualificações profissionalizantes que posteriormente foram referendadas na ocupação de postos de trabalhos e mais tarde serviram de base para a regulamentação das profissões. Esses movimentos avançaram com a divisão social do trabalho nos modelos tayloristas e fordistas de produção, como já foi falado anteriormente neste capítulo.

O profissional, no modelo de competência, teria uma visão mais ampla sobre sua profissão e na sua prática colocaria conteúdos de outras áreas de conhecimento, combinando-os criteriosamente, pela sua própria experiência prática e, assim, desenvolveria ações mais resolutivas no enfrentamento de eventos não previsíveis em seu trabalho (Ramos, 2002).

Ao analisar os pressupostos da aprendizagem pela experiência Zarifian (2001) coloca que é necessário compreender o seu papel para a aprendizagem profissional e destaca que há limitações nesse processo, pois a experiência remete a um corpus de conhecimentos que antecede o fenômeno. Esses conhecimentos estimulam o trabalhador a estabelecer novos modos operatórios ou novas regras de ação para enfrentar o evento que se apresenta. O conhecimento anteriormente desenvolvido permitiria a reflexão para aprofundar ou construir novos conhecimentos. Portanto, para tal, é necessário ter conhecimentos anteriores, sejam estes repassados por meio de regras e rotinas ou mesmo adquiridos pelo trabalhador na formação. $O$ autor destaca que o sistema educativo e os professores permitem ao indivíduo o amadurecimento das responsabilidades e dos conhecimentos que consideram ser a 
base para o desenvolvimento da lógica da competência. Afirma ainda que as competências adquiridas na relação educativa são cristalizadas no domínio da linguagem e de seus usos.

Quanto ao início do modelo de educação baseada em competência Witt (2005, p.65) refere o surgimento, em um movimento de educação e treinamento fundamentado na "[...] pedagogia com base no desempenho ou pedagogia de domínio[...]", nos Estados Unidos, deste na década de 1960. E a sua institucionalização ocorreu em um movimento que teve como participantes: empregado, empregador e governo. Esse último, o governo, convocado para possibilitar a implementação do modelo por meio de Políticas Públicas que integrassem os projetos. Entre essas a educação geral deveria, portanto,

[...] analisar/identificar/repertoriar permanentemente as competências requeridas pelos empregos e as adquiridas pelos trabalhadores, para reformar os sistemas de educação geral e profissional e implantar projetos de educação permanente [...] (Witt, 2005, p.65).

Nesse sentido, no setor saúde para o desenvolvimento do saber no trabalho se argumenta sobre a relação com a realidade em que o mesmo é desenvolvido, para Egry (1996, p.102):

O saber construído, enquanto um instrumento para se interpor ao real, deve ser permanentemente exposto à crítica, buscando principalmente as contradições entre o discurso sobre a razão da assistência e o instrumento que possibilita mudar o objeto rumo à finalidade [...] a escolha do objeto bem como do recorte privilegiado de intervenção, antes de tudo, passa pela compreensão do significado desse objeto e de sua articulação com a totalidade social maior e menor.

Schraiber e Machado (1997, p.286), ao discutirem agenda para as questões relacionadas aos trabalhadores em saúde no Brasil, referiram que:

Na primeira abordagem, os recursos humanos são vistos como questão pertencente à produção e aquisição dos conhecimentos científicos, como algo da esfera da ciência e da educação escolar. Nesse "mundo pré-trabalho", que ademais é concebido como fator anterior e soberano ao trabalho (o saber preside o trabalho), encontrar-se-iam as explicações e soluções para os problemas do trabalho. O que seria o trabalho, nesta visão? Seria a prática, 
aplicação, de saberes. Como um "espelho" da formação escolar ou da capacitação profissional, o trabalho dependeria principalmente do desempenho pessoal e individualizado de cada profissional. Por isso, este trabalhador (ou agente do trabalho) é concebido como indivíduo particular e privado.

$\mathrm{Na}$ observação do desempenho das atividades permite que se reconheçam as competências e, assim, se poderá desenvolver um processo que avalie as competências desenvolvidas na formação deste profissional. Para que isso ocorra, Egry, Marques e Fonseca (2006) afirmam que o processo é complexo e que necessita utilizar diferentes instrumentos para, assim, verificar quais saberes foram mobilizados para o enfrentamento da situação concreta de trabalho. Entre os saberes mobilizados, as autoras destacam que o saber-ser é transversal e será expresso por "[...] atitudes de solidariedade, civilidade, compartilhamento, responsabilidade e ética. [...]" (p.239-40).

Ribeiro (2009) aponta que o saber ser ético profissional do enfermeiro está relacionado ao saber-ser ético profissional dos auxiliares de enfermagem discutidos por Marques (2007), a similaridade foi considerada favorável pela autora, uma vez que, os profissionais pertencem à mesma categoria. Os saberes destacados por Ribeiro (2009) no estudo foram: compreender o âmbito das ações de enfermagem na produção dos serviços de saúde; mobilizar saberes para avaliar contextos e tomar decisões; interagir com usuários e seus familiares, demonstrando atenção às várias formas de manifestação das suas necessidades e demandas; perceber, compreender e respeitar-se como cidadão e como trabalhador de saúde; demonstrar responsabilidade para com usuários e equipe nas situações de trabalho; interagir com equipe de trabalho de acordo com os valores que regem o trabalho da enfermagem; compreender e posicionar-se frente ás condições de trabalho existentes nas instituições e, respeitar os direitos dos usuários como cidadãos.

Leonello (2007, p.39) afirma que a dimensão do saber-ser representa o compromisso social do profissional com a realidade em que atua e, logo, com capacidade de transformá-la com o objetivo de melhorar as condições para a saúde e vida das pessoas. Neste caso, destaca que a formação de profissionais no setor saúde: 
[...] implica articular os diferentes saberes para a construção de uma prática profissional pautada não somente na aquisição e incorporação de conhecimentos e habilidades, mas em atitudes pessoais e relacionais que visem à construção de um projeto comum para a transformação da realidade em saúde.

É na relação dinâmica dos saberes: saber-saber, saber-fazer, saber-ser e saber-conviver que se proporciona uma formação profissional que permitirá o desenvolvimento de competências em uma prática comprometida com a realidade. E, nesse sentido, reconhecer e enfrentar as necessidades em saúde.

\subsubsection{Competência profissional}

Ser competente é responder à questão: "O que fazer, quando não se diz mais como fazer?" (Zarifian, 2003, p.84).

A autonomia, o compromisso, a criatividade e a responsabilidade são reconhecidas pelo autor como requisitos para um profissional competente que os utiliza na busca de soluções para os eventos com os quais se depara na vida profissional. Ao contrário, aquele profissional que é descomprometido com a realidade que tem que enfrentar, buscará nas normas e nas rotinas previamente estabelecidas uma maneira para solucionar o evento que se apresenta. Para o autor, ao agir dessa maneira, para enfrentar um evento, o profissional não se compromete com as consequências das ações que desenvolve e atribui o resultado das mesmas ao próprio serviço, chegando mesmo a justificar a insatisfação do usuário por esta razão.

A iniciativa é considerada por Zarifian (2003) um componente fundamental para a autonomia. Considera que para ter iniciativa o sujeito tem que agir ante uma situação na sua vida profissional. Logo, ao se deparar com uma dada situação, deverá iniciar alguma coisa para modificá-la. Define a competência como "a iniciativa sob a condição de autonomia; é determinar um começo em uma área de indeterminação" (p.87). Refere que esta autonomia está relacionada ao agir e resolver por si mesmo, ou seja, não está restrita às definições de regras que lhe são próprias. 
$\mathrm{Na}$ relação que o profissional estabelece com a organização do seu trabalho, primeiramente passa pelas condições que the são dadas por aqueles que organizam ou detêm os meios para a produção. Nesses casos, na ação o profissional deverá ter condições materiais necessárias, assim como ter a possibilidade de mudar a regra previamente estabelecida para adotar critérios mais flexíveis e criativos na própria ação. Nessa perspectiva, o compromisso do profissional com o usuário dependerá diretamente da organização do processo de produção em que se insere a ação.

Zarifian (2003) afirma que o trabalhador possui somente a sua capacidade de trabalho para vender, isto é, todo o restante envolvido no processo de produção, as condições dadas para a produção, não são suas e pouco poderá definir e decidir sobre elas. Para o autor, é necessário que haja uma forma de relacionar esta capacidade de trabalho com todo o resto envolvido na produção por meio de instrução, qualificação ou formação específica para o trabalho. É na possibilidade de articular a sua capacidade de trabalho com as condições para o trabalho que permitem ao trabalhador desenvolver mais autonomia e criatividade. Ramos (2002, p.297), ao discutir a formação dos trabalhadores para o modelo de competência, refere que:

[...] a lógica da competência não se limita a propor que a escola promova o desenvolvimento de competências para a atuação autônoma e responsável na vida ativa, mas prescreve, em certa medida, que competências devem ser essas, associadas às diferentes esferas de atividades: técnico-profissional, econômica, social, política e cultural.

Para a tomada de iniciativa e consequentemente o seu sucesso, é necessária certa liberdade da organização do processo de produção que permita ao trabalhador a mobilização de recursos para a ação. Zarifian (2003) identifica, nesse movimento, basicamente dois tipos de recursos: recursos internos e recursos coletivos. Os recursos internos são definidos pelo autor como sendo os recursos pessoais, adquiridos pelo próprio indivíduo. Os recursos coletivos são os que estão disponibilizados pela organização da empresa, entre eles encontram-se: aperfeiçoamentos, formações, apoio de 
colegas etc. A seguir se representa o esquema que identifica os recursos e a relação entre eles proposto pelo autor.

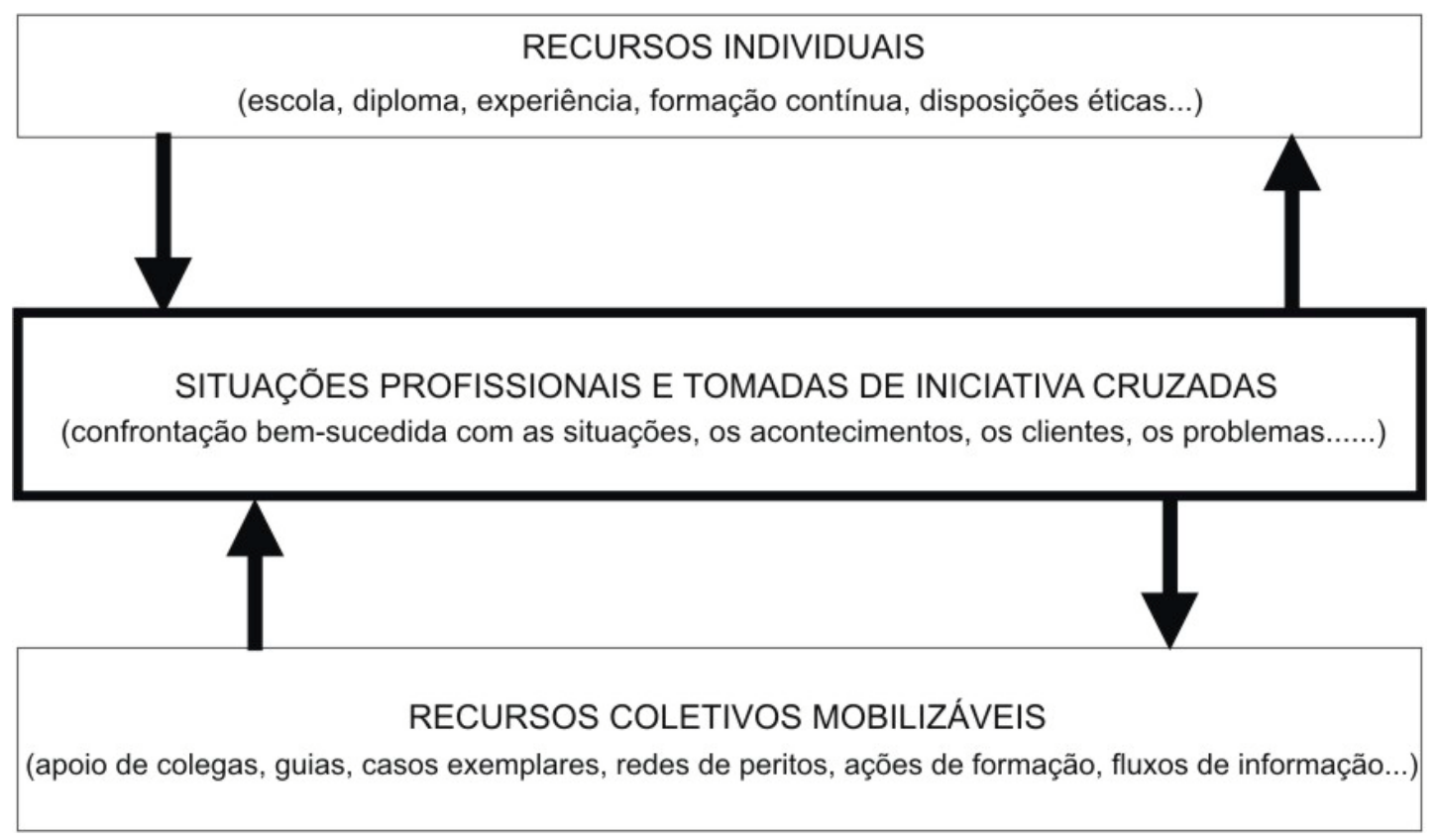

Figura 1 - Esquema ilustrativo da tomada de iniciativa do profissional no trabalho Fonte: Zarifian (2003, p.89)

No movimento de iniciativa e criatividade para o enfrentamento do evento no trabalho se encontra uma questão anterior, pois é nela que reside a base para a mobilização pessoal em questão. Neste caso, fala-se do reconhecimento do que é um evento a ser enfrentado e qual é a maneira que se tem para enfrentá-lo. Para tal, o trabalhador deve julgar e discernir sobre o modo de agir sendo que o julgamento, neste caso, pressupõe uma avaliação sobre a situação.

Julgar é fazer a escolha sobre qual é a melhor maneira de enfrentar a questão. Não que haja uma única forma ou único caminho, mas os envolvidos deverão escolher qual é a possibilidade de intervir e com quais recursos poderão contar para atingir o objetivo proposto. $\mathrm{O}$ julgamento deve ser compreendido como uma etapa contínua do processo, pois está envolvido na própria ação e em direção a ela.

Quanto às contradições da tomada de iniciativa em determinados modelos de produção, Zarifian (2003) chama a atenção afirmando que a iniciativa é identificada no trabalhador, àquele que atua diretamente na 
confecção do produto, é positiva em relação ao objetivo estabelecido para se atingir os resultados desejados. Porém, considera-se que a iniciativa do trabalhador que está na supervisão somente ocorrerá se acontecer uma situação desfavorável à produção, ou seja, a iniciativa do sujeito que se encontra na supervisão do trabalho ocorre em situações negativas ou de desvios da produção. Portanto, existem iniciativas que serão mobilizadas em momentos diferentes na produção, mas que mantêm o princípio da produção, ou seja, busca atingir o objetivo proposto.

Fonseca e Bertolozzi (1993, p.28) referem que o trabalho para o desenvolvimento da assistência em saúde se diferencia pelo referencial teórico no qual ele é sustentado e definem a avaliação na perspectiva da saúde coletiva como:

[...] avaliar as condições de saúde-doença da clientela, o ponto de vista da saúde coletiva, significa buscar a expressão individual ou singular das condições gerais do processo de reprodução social. Significa detectar a maneira como cada pessoa, com a sua bagagem genética, incorpora e manifesta os processos que ocorrem na sua classe ou grupo social e na sociedade, destrutivos ou benéficos para a saúde. Afirmar isso não significa negar a individualidade inerente a cada ser humano, senão que reolhá-la, de acordo com a relação que se estabelece entre os homens, na construção da vida social.

Em uma perspectiva funcionalista, como reconhecem as autoras, a avaliação de uma situação para posterior intervenção significa atribuir valores a situação conforme já propõe um modelo anteriormente estabelecido. Assim, o encontro ou cruzamento de variáveis em um evento já teriam o resultado previamente estabelecido, logo, para intervir, bastaria seguir o modelo. $\mathrm{Na}$ perspectiva deste referencial seriam negadas as especificidades de dada situação, assim como não seriam estabelecidas as relações deste evento com a realidade como um todo. Portanto, o fenômeno seria compreendido por si só e não seria reconhecida a sua determinação histórico-social e as contradições que o constituem dialeticamente. Na concepção funcionalista a sociedade e os seres humanos teriam uma lógica de funcionamento previamente definidos e estes seriam por si só, não haveria a percepção do fenômeno com relação ao todo. 
Com o desenvolvimento da sociedade capitalista e a agudização das contradições que lhe são inerentes verificou-se que a explicação dos fatos sociais baseadas na ciência positiva, oriunda das ciências naturais obtinha apenas uma visão parcial e dicotomizada da realidade, não permitindo a visualização do todo concebendo a sociedade como uma máquina e os homens como suas engrenagens, cada qual com seu "funcionamento" pré-determinado, que não mantinha qualquer aderência com o social mais amplo. Visto dessa forma, o processo saúde-doença refletia apenas as condições de equilíbrio/ desequilíbrio ou normalidade/anormalidade desta máquina (Fonseca; Egry; Bertolozzi, 2006, p.21-2).

A dialética para Konder (1981, p.8) é definida como "[...] o modo de pensarmos as contradições da realidade, o modo de compreendermos a realidade como essencialmente contraditória e em permanente transformação [...]". A compreensão dessa totalidade permite ao homem identificar as contradições historicamente construídas que determinam e constituem tal fenômeno. É com a compreensão ampla sobre a realidade que o sujeito reflete criticamente sobre a determinação da mesma e permite-se preestabelecer a realidade desejada ou a situação a ser atingida. O julgamento de uma situação com visão crítica dá a possibilidade para que o sujeito compreenda as contradições que conforma o fenômeno e, ainda, a intervenção que é possível de ser realizada. Nesse caso, independente da dimensão, na qual se dará a intervenção o sujeito terá sempre em mente a totalidade, a historicidade e a dinamicidade que constitui o fenômeno observado. 


\section{METODOLOGIA}

Trata-se de um estudo exploratório descritivo, desenvolvido com abordagem qualitativa sobre a competência avaliativa do enfermeiro para reconhecer e enfrentar as necessidades em saúde das famílias moradoras nas áreas de abrangências das unidades de saúde do Distrito Sanitário Boa Vista em Curitiba-PR.

A pesquisa está ancorada na Teoria da Intervenção Práxica da Enfermagem em Saúde Coletiva (TIPESC), proposta por Egry (1996), que tem fundamentação no Materialismo Histórico e Dialético (MHD). Na proposição metodológica da TIPESC a autora descreve as cinco etapas:

- Conhecimento da realidade objetiva;

- Interpretação da realidade objetiva;

- Construção de projeto de intervenção na realidade objetiva;

- Intervenção na realidade objetiva;

- Reinterpretação da realidade objetiva

Este estudo desenvolveu as três primeiras etapas citadas acima, nas quais foram exploradas as dimensões do objeto estudado, singular, particular e estrutural, para superar a visão simplificada sobre o mesmo por meio da análise das contradições reconhecidas na sua caracterização. Para Minayo (2004), a fase exploratória da pesquisa pode ser considerada a própria pesquisa, visto que esta possibilita a construção de conhecimentos e respostas às hipóteses anteriormente estabelecidas. Triviños (1987) afirma que os estudos exploratórios permitem ao pesquisador construir conhecimentos, ter mais experiências sobre determinado problema e servir como base para levantar possíveis elementos que se relacionam ao problema para posteriormente desenvolver outra fase da pesquisa. Neste caso, a pesquisa descritiva permite "[...] descrever 'com exatidão' os fatos e fenômenos de determinada realidade [...]" (p.109-10).

A terceira etapa foi a identificação dos saberes avaliativos do enfermeiro da atenção básica necessários para avaliação e enfrentamento de necessidades em saúde, segundo as temáticas empíricas e analíticas evidenciadas no 
estudo. No final do capítulo de resultados o Quadro 7 apresenta os saberes e este é comentado no capítulo de discussão.

Quanto à quarta e quinta etapa da proposição metodológica que não foram desenvolvidas, justifica-se com a decisão tomada desde o projeto que originou esta pesquisa, pois não se pretendeu dar conta das mesmas, visto o tempo delimitado para a elaboração e o desenvolvimento deste estudo no Programa de Doutorado e, ainda, pela complexidade da base filosófica, do referencial metodológico e do objeto selecionados. Diante disso, como pode ser verificado nos objetivos propostos, não se apontou que estas etapas seriam desenvolvidas.

As categorias de análise previamente estabelecidas foram: necessidades em saúde, processo de trabalho do enfermeiro na atenção básica; intervenções do enfermeiro na atenção básica para atender às necessidades em saúde e as três dimensões das competências saber-saber avaliar, saber-fazer avaliar e saber-ser ético profissional mobilizadas para a avaliação.

Ao propor previamente as categorias de análise, tornou-se possível explorar a busca de dados para se reconhecer a diversidade das dimensões do objeto estudado, assim como permitiu maior aproximação com as dimensões da realidade estudada. Outra questão relevante foi que ao se aproximar mais do objeto estudado houve necessidade de se aprofundar o referencial teórico do estudo, uma vez que a aproximação instigava novas reflexões e, assim, exigia que o pesquisador compreendesse a "nova realidade" encontrada.

As coletas de dados nas fontes primárias e secundárias foram em diferentes momentos, esses processos seguiram as seguintes etapas:

1. Levantamento do perfil socioeconômico, demográfico e epidemiológico da população de Curitiba e do território de abrangência das Unidades de Saúde, Distrito Boa Vista.

2. Caracterização da estrutura, organização e funcionamento das Unidades de Saúde do Distrito Sanitário Boa Vista, Curitiba-PR.

3. Reconhecimento dos temas abordados nas propostas aprovadas nas 6 (seis) Conferências Municipais ocorridas nos últimos dez anos (1997, 1999, 2001, 2003, 2005 e 2007). 
4. Identificação dos programas e protocolos vigentes na Secretaria Municipal de Saúde de Curitiba-PR.

5. Caracterização do trabalho assistencial dos enfermeiros nas Unidades de Saúde estudadas pela identificação do processo de reconhecimento das necessidades em saúde das famílias moradoras das áreas de abrangência sob sua responsabilidade; da identificação das necessidades em saúde das famílias reconhecidas pelas enfermeiras; da identificação das intervenções realizadas pelos enfermeiros para atender às necessidades em saúde das famílias moradoras das áreas de abrangência das unidades de saúde estudadas e pela identificação dos recursos utilizados pelas enfermeiras nas intervenções de saúde para enfrentar as necessidades em saúde reconhecidas.

O estudo foi desenvolvido no Distrito Boa Vista, região norte do município de Curitiba-PR, com vinte e cinco enfermeiras que trabalhavam nas Unidades de Saúde da Atenção Básica e tiveram disponibilidade para participar da pesquisa. O local foi selecionado devido às investigações anteriores desenvolvidas pelo grupo de pesquisa, ao qual este estudo está vinculado. Outras questões foram consideradas nesta seleção, a organização do trabalho dos enfermeiros nas unidades de atenção básica dispõe de registros informatizados para os atendimentos à mulher e à criança nas consultas de enfermagem, segundo o CIPESC ${ }^{\circledR}$ e por ser o Distrito Sanitário campo de estágios para disciplinas do Curso de Enfermagem da Universidade Federal do Paraná (UFPR), no qual a pesquisadora atua como docente da área de saúde coletiva.

$\mathrm{Na}$ caracterização de Curitiba o referencial metodológico foi a metodologia investigativa proposta por Breilh e Tillería (2009) ${ }^{3}$ que objetiva

${ }^{3}$ Com a experiência do período sanduíche foi possível a leitura do livro: "Aceleración global y despojo en Ecuador: el retroceso del derecho a la vida y la salud pública en las décadas neoliberales" de autoria do Professor Dr. Jaime Breilh e da jornalista Msc. Ylonka Tillería, publicado pela Universidad Andina Simon Bolívar/Abya-Yala na cidade de Quito-EC, no momento sem publicação no Brasil. 
compreender a determinação do processo saúde-doença vivido pela população por meio de dados secundários. Esses dados permitem refletir sobre os processos existentes nas dimensões estrutural, particular e singular da realidade de uma sociedade, em um tempo histórico, que conformam a realidade observada.

\subsection{ASPECTOS ÉTICOS}

Os aspectos éticos e legais da pesquisa seguiram as normatizações dos princípios das pesquisas com seres humanos referendados pela resolução 196/96 do Conselho Nacional de Saúde, que garante aos sujeitos envolvidos o sigilo, o anonimato e o direito a desistência sem prejuízo para os envolvidos no estudo (Conselho Nacional de Saúde, 1996). Para tal, o projeto de pesquisa foi submetido ao Comitê de Ética em Pesquisa da Escola de Enfermagem da Universidade de São Paulo com parecer favorável para o processo n. ${ }^{\circ} 740 / 2008$ e, ao Comitê de Ética da Secretaria Municipal de Saúde de Curitiba para avaliação de viabilidade com o parecer favorável no processo n. ${ }^{\circ}$ 09/2008, Anexos A e B, respectivamente.

Posteriormente, foram realizadas visitas ao Distrito Boa Vista para contato com a coordenação do mesmo e, posteriormente, com as Autoridades Sanitárias das Unidades de Saúde para a autorização do agendamento de entrevistas com as enfermeiras. Em todas as oportunidades foram feitos os convites aos profissionais que estavam presentes para o agendamento das entrevistas com aquelas que aceitassem participar do estudo. $O$ primeiro contato com algumas Unidades de Saúde foi telefônico e em outras foi realizado visita para conversar com os possíveis sujeitos do estudo. Para Chizzotti (1991), a coleta de dados pode exigir prévias negociações tanto com as instituições como com as pessoas que serão informantes na coleta de dados. 


\subsection{COLETA DE DADOS EMPÍRICOS}

As categorias empíricas são definidas por Minayo (2004) como sendo aquelas construídas a partir do trabalho de campo. "[...] Elas têm a propriedade de conseguir apreender as determinações e as especificidades que se expressam na realidade empírica [...]" (p.94). E as categorias analíticas como sendo aquelas que

[...] retêm historicamente as relações sociais fundamentais e podem ser consideradas balizas para o conhecimento do objeto nos seus aspectos gerais. Elas mesmas comportam vários graus de abstração, generalização e de aproximação [...] (p.94).

Os sujeitos da pesquisa foram vinte e cinco enfermeiras de quatorze Unidades de Saúde do Distrito Boa Vista que aceitaram participar da entrevista por meio da assinatura do Termo de Consentimento Livre Esclarecido (TCLE) (Apêndice A). Todas as entrevistas foram gravadas com a autorização das entrevistadas e posteriormente foram transcritas integralmente pela pesquisadora.

Para a apresentação e abordagem aos sujeitos foi utilizado um rapport (Apêndice B) e o Termo de Consentimento Livre e Esclarecido (Apêndice A). $\mathrm{Na}$ aproximação inicial se verificavam o interesse e a disponibilidade para participação da pesquisa. Com os sujeitos que se constatava a disponibilidade eram agendados o dia, horário e o local da entrevista. Todas as entrevistadas escolheram realizar a entrevista na própria Unidade de Saúde no dia e horário que havia menor demanda para atendimento, ou seja, no qual elas tinham maior disponibilidade para conceder a entrevista. O tempo médio utilizado em cada entrevistada foi de 40 minutos. Em todas as Unidades de Saúde houve a disponibilidade das entrevistadas para apresentar os setores e falar da rotina de atendimentos, isso ocorreu mesmo quando não eram solicitadas.

As entrevistas foram individuais, as enfermeiras foram solicitadas a descrever situações de reconhecimento e enfrentamento das necessidades em saúde de famílias no seu cotidiano, assim como situações nas quais reconheceram necessidades em saúde e os recursos de que dispunham 
para as intervenções, conforme o roteiro de perguntas semiestruturado, previamente elaborado e validado (Apêndice $C$ ). A validação do instrumento foi com um profissional de região assemelhada e após pequeno ajuste nas questões as entrevistas foram iniciadas.

Foram realizadas vinte e sete entrevistas no período de 15 julho a 5 de setembro de 2008, porém por problemas técnicos, gravação inaudível, duas foram desprezadas e foram transcritas as vinte e cinco que compõem os dados deste estudo. Cabe registrar que no período das entrevistas havia trinta e cinco enfermeiros lotados nas 16 Unidades de Saúde do Distrito Boa Vista. Entre estes profissionais alguns se encontravam de licença ou férias. Entre os profissionais consultados apenas um não aceitou participar do estudo. Para definir o número de entrevistas realizadas se seguiu o critério de saturação dos dados (Minayo, 2004).

$\mathrm{Na}$ sistematização dos dados das entrevistas evidenciaram-se os núcleos de sentido dos discursos dos quais emergiram os temas e os subtemas sobre o reconhecimento das necessidades, as necessidades reconhecidas, o enfrentamento das necessidades e os recursos utilizados no enfrentamento das necessidades em saúde das famílias (Bardin, 2008). Para Fiorin (2005, p.24), o tema é evidenciado nos discursos a partir da compreensão de que ele "[...] é o elemento semântico que designa um elemento não-presente no mundo natural, mas que exerce o papel de categoria ordenada dos fatos observáveis [...]". Para o autor, a fala do indivíduo, à qual se refere como discurso, permite explorar os temas relacionados ao seu contexto social ao afirmar que:

[...] o discurso é a materialidade das formações ideológicas, sendo, por isso, determinado por elas, o texto é unicamente um lugar de manipulação consciente, em que o homem organiza da melhor maneira possível, os elementos de expressão que estão a sua disposição para veicular seu discurso. O texto é, pois, individual, enquanto o discurso é social. Há um nível grande de liberdade no âmbito da textualização, enquanto, no nível discursivo, o homem está preso aos temas e às figuras das formações discursivas existentes na formação social em que está inserido (Fiorin, 2005, p.41). 


\subsection{COLETA DE DADOS SECUNDÁRIOS}

Com os dados secundários buscou-se explorar as dimensões da realidade da vida e saúde da população moradora do Distrito Boa Vista, no município de Curitiba-PR. A coleta foi por meio de consultas aos sites das seguintes instituições: Instituto Paranaense de Desenvolvimento Econômico e Social (IPARDES), Instituto de Pesquisa e Planejamento Urbano de Curitiba (IPPUC), Secretaria Municipal de Saúde de Curitiba (SMS-CTBA), Secretaria Estadual de Saúde do Paraná (SESA) e dados disponibilizados pelo Distrito Sanitário Boa Vista.

Em relação ao uso de dados secundários nesta pesquisa também se investigaram: os discursos das Conferências Municipais de Saúde, em seus Relatórios Finais, ocorridas nos últimos 10 (dez) anos (1997-2007), nas quais foram definidas propostas de intervenção em saúde referendadas pelo movimento social organizado, trabalhadores e gestores do setor que fundamentaram o setor para propor suas atuais Políticas Públicas. Por fim, foram analisados os discursos dos programas, protocolos e manuais vigentes na Secretaria Municipal de Saúde para compreender a organização dos serviços e as intervenções em saúde que são desenvolvidas pelas enfermeiras na Atenção Básica para atender às necessidades em saúde das famílias. Ao todo foram analisados vinte e seis documentos que se encontravam no site da secretaria no período de coleta dos dados.

Todos os dados foram coletados no período de fevereiro a março de 2008. Depois de coletados foram arquivados para posterior análise. No caso dos protocolos e programas buscou-se identificar se em algum dos documentos havia referência a outros que não estavam disponíveis no site. Para aqueles que não foram encontrados se contou com a ajuda da Coordenação da Enfermagem da SMS-CTBA e outros profissionais da instituição para orientar nova busca ou mesmo disponibilizar cópia impressa. 


\subsection{ANÁLISE DOS DADOS}

Os dados foram analisados na perspectiva Materialista Histórica e Dialética no sentido de se refletir sobre a competência avaliativa do enfermeiro da atenção básica em saúde para o reconhecimento e enfrentamento de necessidades em saúde que é objeto do presente estudo. Segundo Fiorin (2005, p.11), ainda que o discurso seja emitido pelo eu os elementos vão além do indivíduo, pois sua construção se dá no social.

O discurso são combinações de elementos lingüísticos (frases ou conjunto constituído de muitas frases), usadas pelos falantes com o propósito de exprimir seus pensamentos, de falar do mundo exterior ou de seu mundo interior, de agir sobre o mundo [...]

Na caracterização do Município de Curitiba se buscou analisar dados que permitissem refletir criticamente sobre as condições de vida da população moradora no município em uma perspectiva histórica e ao mesmo tempo contextualizando-a no estado do Paraná e no Brasil.

$\mathrm{Na}$ análise dos seis Relatórios Finais de Conferências Municipais de Saúde ocorridas nos últimos dez anos (1997, 1999, 2001, 2003, 2005 e 2007 identificaram-se os temas abordados nas propostas aprovadas, a forma de organização do evento e o número de participantes na plenária final. Após longo processo de pré-análise dos materiais foi organizado um roteiro de temáticas para agrupar as intervenções aprovadas em cada um dos relatórios.

Portanto, as intervenções aprovadas em cada uma das Conferências foram agrupadas segundo as temáticas: promoção da saúde; atenção básica; atenção pré-hospitalar; atenção de média e alta complexidade; assistência farmacêutica, segurança alimentar e nutricional; saúde bucal; saúde mental; Diabetes; Hipertensão Arterial; cânceres e neoplasias; patologias agudas e doenças transmissiveis; violências e causas externas; HIVIAIDS; Hanseníase; Tuberculose; saúde do idoso, saúde da mulher, saúde da criança; saúde do adolescente; saúde do trabalhador e portador de deficiência. 
Para compreender o discurso dos programas e protocolos vigentes na Secretaria Municipal de Saúde de Curitiba foram levantados os documentos e as publicações disponíveis no site da instituição. Foram encontrados vinte e seis documentos vigentes que normatizam e orientam intervenções a serem desenvolvidas nos serviços de saúde. Nestes foram analisados os discursos para refletir sobre suas fundamentações teóricas para a organização da intervenção na rede de serviços públicos e contratados do setor saúde no território municipal. Para os documentos que tinham duas versões foi considerada a versão mais atualizada.

Para análise do discurso das enfermeiras as entrevistas foram transcritas e agrupadas por Unidade de Saúde. Posteriormente todas as entrevistas foram agrupadas por pergunta. Nesta etapa se identificaram as temáticas emergentes no discurso, e assim se prosseguiu identificando nas falas os núcleos de sentido representativos de cada uma das temáticas. Após exaustiva leitura do material preparado nesta fase, organizaram-se os subtemas emergentes em cada temática. Logo, novamente se agruparam os núcleos de sentido atendendo à representatividade do subtema. Assim, se constituíram quatro quadros segundo as temáticas e seus subtemas:

- No tema como reconhece necessidades em saúde de uma família foram identificados quatro subtemas - aproximação com a realidade das famílias e usuários para reconhecer necessidades em saúde; desenvolver atividades programáticas para reconhecer necessidades em saúde das famílias; processo de trabalho na Unidade de Saúde para reconhecer necessidades em saúde das famílias e articulação com as instituições locais para reconhecer necessidades em saúde das famílias.

- No tema as necessidades reconhecidas foram identificados quatro subtemas - as necessidades em saúde dos usuários; as necessidades em saúde nas famílias; as necessidades em saúde nas comunidades e as necessidades em saúde nas demandas nas Unidades de Saúde.

- No tema intervenções para enfrentar as necessidades em saúde reconhecidas foram identificados nove subtemas - intervenções 
desenvolvidas nas unidades de saúde; intervenções no domicílio; intervenções segundo o modelo de atenção à saúde; intervenções para promoção da saúde e prevenção de doenças; intervenções articuladas com outros setores e serviços de saúde de outros níveis de complexidade; intervenções desenvolvidas em equipe; capacitação da equipe para intervir; intervenções com a mobilização da comunidade, família e usuários, e intervenção com a participação da família.

- No tema recursos para desenvolver intervenções em situações nas quais foram reconhecidas necessidades em saúde foram identificados sete subtemas - os recursos disponíveis na Unidade de Saúde para planejar e desenvolver intervenções; recursos de outros serviços de saúde para o desenvolvimento de intervenções; articulação com instituições, técnicos e programas de outros setores como recursos para a intervenção; recursos comunitários para a intervenção; recursos da família e dos usuários para o desenvolvimento da intervenção; recursos da enfermeira para o desenvolvimento de intervenções em saúde e dificuldades de recursos para o desenvolvimento da intervenção.

Os núcleos de sentido apresentados nos quadros referidos acima não têm a identificação dos sujeitos, enfermeiras entrevistadas, visto que ao indicar o emissor do discurso as identificações eram fáceis devido às características das comunidades, das Unidades de Saúde e dos processos de trabalhos referidos nas entrevistas.

Essa decisão foi tomada após a realização de consulta a uma enfermeira da Secretaria de Saúde, na qual se solicitou à profissional que lesse parte do material agrupado por questões, com codificação para o emissor do discurso, no caso já somente com os núcleos de sentido, para que se verificasse a possibilidade de identificação dos sujeitos. Ao se confirmar a possibilidade já levantada pela pesquisadora e orientadora do estudo, decidiu-se pela forma de apresentação descrita, ou seja, núcleos de sentido sem a identificação do emissor, como se fossem de um sujeito único. O objetivo foi preservar o direito ao anonimato das entrevistadas. 
Para Minayo (2004, p.237), a "[...] investigação social enquanto processo de produção e produto é ao mesmo tempo uma objetivação da realidade e uma objetivação do investigador que se torna também produto de sua própria produção." Portanto, o processo foi de contínua reflexão, uma vez que a aproximação com o objeto instigava a retomada do referencial teórico para permitir olhar as diferentes dimensões exploradas. Nesse sentido, o presente relato se tornou significativamente denso. 


\section{RESULTADOS}

Compõem este capítulo dados referentes à realidade da vida e de saúde da população moradora do Distrito Boa Vista, no município de Curitiba Paraná. Análise dos discursos das seis Conferências Municipais de Saúde ocorridas nos últimos 10 anos (1997-2007), nas quais foram definidas as propostas de intervenção em saúde referendadas pelo movimento social organizado, trabalhadores e gestores do setor que fundamentaram o setor para propor Políticas Públicas. Outros discursos analisados foram referentes aos programas, protocolos e manuais vigentes na Secretaria Municipal de Saúde na busca de compreender a organização dos serviços e as intervenções em saúde que estes desenvolvem. Por fim, foram analisados os discursos dos enfermeiros, coletados por meio de entrevistas, para identificar como reconhecem e enfrentam as necessidades em saúde das famílias que moram nas áreas de abrangência sob sua responsabilidade, quais são as necessidades reconhecidas e os recursos disponíveis para o desenvolvimento desse processo.

Os dados foram analisados na perspectiva Materialista Histórica e Dialética, no sentido de refletir sobre a competência avaliativa do enfermeiro da atenção básica em saúde para o reconhecimento e enfrentamento de necessidades em saúde, que é objeto do presente estudo.

\subsection{O MUNICÍPIO DE CURITIBA}

A caracterização do município de Curitiba foi baseada em dados secundários disponíveis nos sites do Instituto Paranaense de Desenvolvimento Econômico e Social (IPARDES), Instituto de Pesquisa e Planejamento Urbano de Curitiba (IPPUC), Secretaria Municipal de Saúde de Curitiba, Secretaria Estadual de Saúde do Paraná e dados disponibilizados pelo Distrito Sanitário Boa Vista em documentos não publicados. A metodologia de seleção e análise dos dados seguiu a proposta investigativa sobre a determinação do processo 
saúde doença de Breilh e Tillería (2009) como já referido no capítulo de metodologia do presente estudo.

$\mathrm{Na}$ análise, apresentada a seguir, procurou-se descrever a representação que o município tem para a sua região, o modelo de produção no território, as características populacionais e o processo saúde-doença vivido pelos indivíduos no território. Para atender aos objetivos da pesquisa foram analisados dados sobre a Regional Boa Vista no sentido de descrever e aprofundar a discussão sobre suas características. Esta etapa da pesquisa permitiu descrever e compreender processos determinantes na qualidade de vida dos indivíduos que vivem nesta realidade.

Cabe registrar que nos dados disponíveis nas instituições consultadas há uma disparidade de períodos nos estudos e nas análises disponibilizados pelas instituições. A maioria do material que é publicado e disponibilizado nos sites do IPPUC e do Instituto Paranaense de Desenvolvimento Econômico e Social (IPARDES) é desenvolvida a partir de bancos de dados gerados por organizações e serviços com ritmos próprios, consequentemente não foi possível delimitar à priori o período que definiria a inclusão e exclusão das publicações, pois isto levaria à exclusão de informações que foram significativas na compreensão da realidade na qual se encontra o objeto estudado. Assim, a delimitação do período para a busca dos dados secundários a serem utilizados ficou pelo critério de proximidade com o tempo das Conferências Municipais de Saúde estudadas (1997-2007) e, ainda, quando os dados analisados no estudo estavam fora do prazo estabelecido, mas não havia outro estudo disponível que tivesse conteúdo próximo no tempo delimitado.

Posteriormente, os resultados apresentados a seguir serão confrontados com o discurso dos enfermeiros sobre o reconhecimento e enfrentamento de necessidades em saúde, a análise dos protocolos vigentes na Secretaria Municipal de Saúde e análise sobre os Relatórios Finais das Conferências de Saúde ocorridas nos últimos 10 anos. 


\subsubsection{Características geográfica, populacional, econômica e social}

Curitiba é um município localizado na região leste do Estado do Paraná, região sul do Brasil. É a capital e o maior município do Estado com $1,75 \%$ da população paranaense. Segundo o Instituto Brasileiro de Geografia e Economia (IBGE) apud IPARDES (2008) toda a população do município, 1.587.315 pessoas (com estimativa de 1.797.408 pessoas para o ano de 2007) é considerada como moradora da zona urbana, pois na análise sobre as atividades econômicas se reconheceu que uma pequena parte da população vivia da produção de atividades em zonas rurais, mas, segundo os critérios do IBGE, suas moradias foram consideradas como zonas urbanas. Portanto, essa pequena parte da população foi descaracterizada como população rural.

O Índice de Desenvolvimento Humano do Município (IDH-M) no ano 2000 foi de 0,856 IDH-M, considerado o mais alto do Estado do Paraná. No Brasil, o município com o IDH-M mais alto no ano 2000 foi o município de São Caetano-SP com índice de 0,919. O crescimento do IDH-M em Curitiba no período de 1991 a 2000 teve a maior contribuição da área da educação, com o crescimento de $41,3 \%$ no período, seguida da renda, $30,8 \%$ e longevidade com o crescimento de 27,9\% (Programa das Nações Unidas (PNUD) - Brasil, 2003).

$\mathrm{Na}$ análise do desenvolvimento social e econômico municipal o Instituto Paranaense de Desenvolvimento Econômico e Social (IPARDES, 2008) refere esperança de vida ao nascer de 71,57 anos, taxa de alfabetização de adultos 96,63\% e renda per capita de $\mathrm{R} \$$ 619,82 em Curitiba. Porém, o estudo mostrou que houve aumento de concentração de renda identificado pelo coeficiente de $\mathrm{Gini}^{4}$, que passou de 0,55 em 1991 para 0,59 em 2000.

4 O coeficiente é utilizado por economistas para verificar a concentração em distribuição de renda e o seu cálculo é baseado na curva de Lorenz. A curva é representada pela distribuição de renda no eixo $\mathrm{x}$ e a distribuição da população de acordo com os níveis de renda correspondente no eixo y. Quanto mais próximo de zero for o coeficiente menor é a concentração de renda, e quanto mais próximo de um maior é a concentração de renda (Barata, 2006). 
Portanto, nos dados referidos os valores do coeficiente no período mostrou a tendência de concentração de renda.

Curitiba é considerado o município sede da região metropolitana, que agrega em território contínuo 12 municípios segundo a área definida pela Lei Federal n. ${ }^{\circ}$ 14/73. A região metropolitana de Curitiba é composta pelos municípios: Almirante Tamandaré, Araucária, Campina Grande do Sul, Campo Largo, Campo Magro, Colombo, Fazenda Rio Grande, Pinhais, Piraquara, Quatro Barras e São José dos Pinhais.

Para o IPARDES, a região metropolitana de Curitiba foi ampliada segundo critérios econômicos e sociais estabelecidos por estudos sobre o Estado do Paraná. Com a ampliação do território a região metropolitana passou a ser denominada mesorregião metropolitana. A mudança foi reconhecida pelas Leis estaduais $\mathrm{n}^{\text {os }} 11.027 / 94,11.096 / 95,12.125 / 98,13.512 / 02$, que incluíram os municípios que hoje compõem uma aglomeração metropolitana. $\mathrm{Na}$ mudança foram incorporados à mesorregião os seguintes municípios: Adrianópolis, Agudos do Sul, Cerro Azul, Doutor Ulysses, Quitandinha, Lapa, Tijucas do Sul e Tunas do Paraná. Entre estes alguns pertencem ao Vale do Ribeira, região de divisa entre os estados do Paraná e São Paulo que se destaca no contexto nacional por suas condições econômica e social precárias. A justificativa apontada para a inclusão dos municípios na mesorregião metropolitana foi para que os mesmos recebessem linhas programáticas de órgãos dos governos federal e estaduais (São Paulo e Paraná) no sentido de estimular o desenvolvimento social e econômico e melhorar a qualidade de vida da população local. Nesta ampliação foram incluídos também municípios do litoral paranaense, conforme demonstrado no mapa da Figura 2, a seguir (IPARDES, 2004a). 


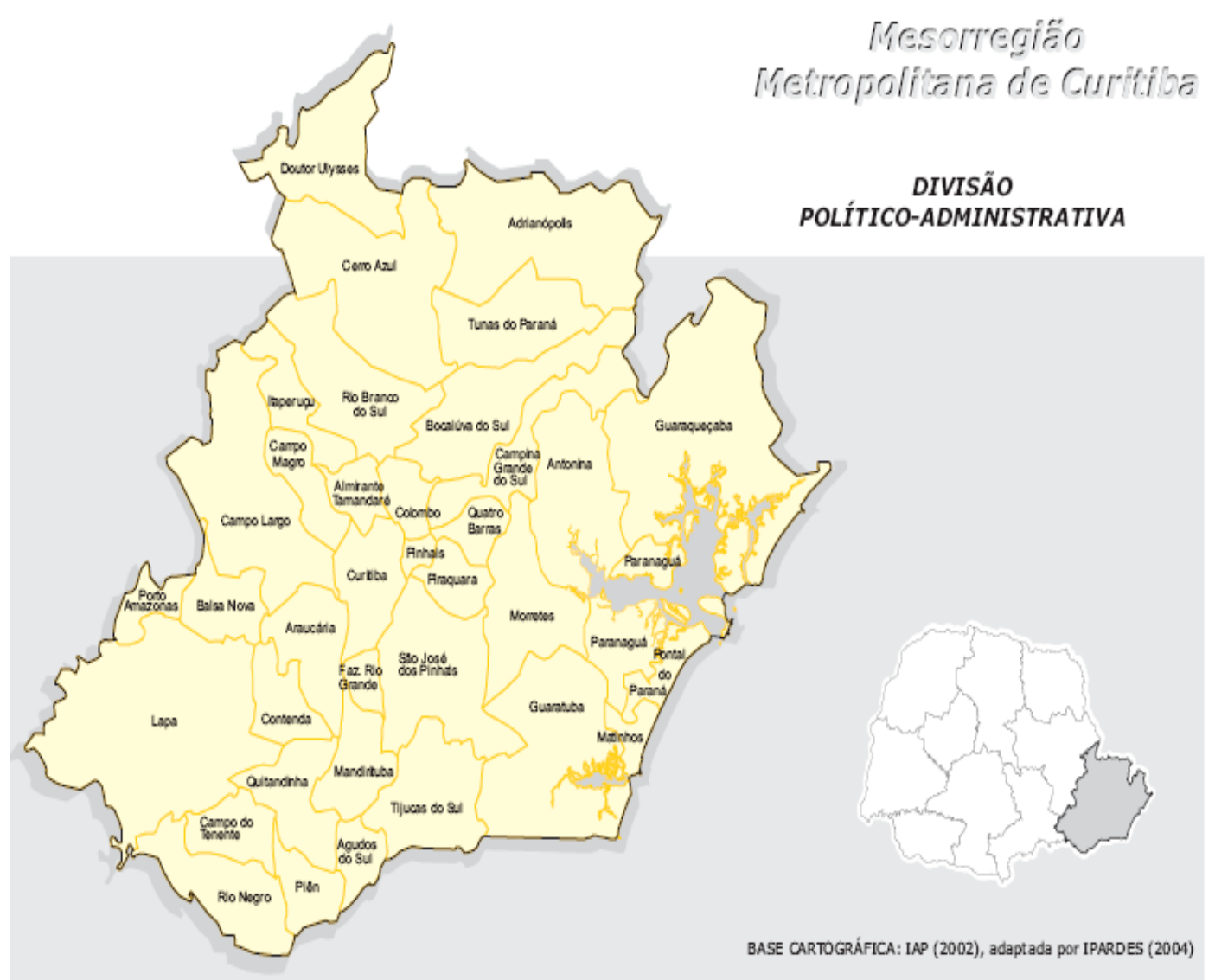

Figura 2 - Representação da composição e localização geográfica da mesorregião metropolitana de Curitiba no estado do Paraná

Fonte: IPARDES (2004a, p.7)

No desenvolvimento econômico recente do Paraná houve processo de intensa modernização na base produtiva concentrada em alguns municípios sede de polos regionais. Nas regiões, assim como nos próprios municípios, pode ser observada significativa disparidade na distribuição da população e desigualdade social. A ocorrência deste fenômeno foi atribuída à inserção da população na produção e, consequentemente, pela sua reprodução social que agregou nos territórios menores grupos populacionais homogêneos e, ao mesmo tempo com diversidades entre si, evidenciando a desigualdade social nos espaços urbanos (IPARDES, 2004a).

O contexto descrito acima permite refletir sobre o agravamento das questões ambientais no Estado. A ocupação acelerada de territórios urbanos nos últimos anos foi sem preparo mínimo de infraestrutura para atender o número de pessoas que passaram a viver nos locais. Entre as condições de despreparo se destaca a falta de organização para a destinação de esgoto e 
de lixos domésticos. Nos espaços rurais, a produção em larga escala de um único produto (monocultura de grãos) levou ao desmatamento, ao uso de agroquímicos e à aplicação de tecnologias para maior produtividade. As consequências desse fenômeno vão além do uso de produtos nocivos à saúde do homem no campo, ou seja, o desmatamento e o uso intenso de agroquímicos também comprometeram os recursos hídricos e o solo utilizado na cultura. O objetivo deste modelo de produção foi atender ao mercado agroexportador, no qual o Paraná tem se destacado no cenário brasileiro nos últimos anos (IPARDES, 2004a).

\begin{abstract}
Desse modo, o desafio de buscar um desenvolvimento socialmente mais equilibrado, evitando a desagregação social, pressupõe a inclusão de amplos segmentos da população, de forma digna, nos processos produtivos e de consumo, bem como o controle e recuperação das condições ambientais. Desses compromissos não estão dispensadas mesmo as regiões mais dinâmicas do Estado, pois, embora concentrem oportunidades econômicas e sociais, essas regiões são também marcadas por acentuada heterogeneidade, a qual, ao conjugar-se à concentração populacional, dá origem a grandes bolsões de miséria. A mesorregião Metropolitana é marcada por esta diferenciação social, possuindo municípios nos dois extremos do quadro social paranaense. Ademais, mesmo municípios melhor situados neste quadro, como Curitiba, de modo particular, apresentam expressivas desigualdades intramunicipais. Sem dúvida, uma gestão pública comprometida em fazer das políticas sociais um instrumento de correção das desigualdades pode trazer efeitos progressivos para a população e para a economia, considerando que ao elevar o patamar de vida da sociedade também são construídas condições para uma inserção mais competitiva. Essa perspectiva representa buscar avanços em políticas que contemplem necessidades dos diferentes segmentos sociais e atenda a especificidades locais, mas pressupõem fundamentalmente que as forças políticas e sociais que definem e realizam as ações governamentais se encontrem alinhadas com os interesses de distribuição da renda e de atendimento à população na direção da maior inclusão, tendo a lucidez de que são fortes os condicionantes para que prevaleça seu caráter excludente (OLIVEIRA, 2001 apud IPARDES, 2004a, p.3).
\end{abstract}

O desafio para a gestão pública apontado pelo IPARDES (2004a) se deve ao desenvolvimento de uma sociedade que nos últimos anos teve acentuada migração populacional da zona rural para a zona urbana. Como referido anteriormente este fenômeno pode ser percebido nos municípios sedes das regiões do Estado com mais oportunidade de inserção do indivíduo na produção. A origem deste processo de migração foi o modelo de produção agrícola adotado no Estado para atender às demandas do comércio 
agroexportador, já mencionado anteriormente, e acentuado pela implantação de indústrias nos territórios das cidades sedes. Curitiba é considerado um dos municípios sedes, no caso da região leste do Estado.

O Paraná é um dos Estados brasileiros com participação significativa na produção de grãos em larga escala para exportação. A produção é retirada do campo por transportes rodoviários e levada ao porto de Paranaguá para ser colocada em navios com o destino dos compradores no comércio internacional. A região portuária do município de Paranaguá pertence à mesorregião metropolitana de Curitiba. Os produtos que são retirados do interior do Estado e de Estados vizinhos, para chegarem ao porto por rodovias, passam por Curitiba ou em rodovias que estão no seu redor.

Na dinâmica da produção e exportação de grãos a população rural e de pequenos municípios são deslocadas na busca de oportunidade de trabalho em indústrias ou serviços que se localizam nos municípios polos. Porém, neste processo de migração as pessoas descobrem uma realidade não muito promissora. Neste caso, a dificuldade de acesso ao trabalho ocorre por vários motivos, entre eles destacam-se o despreparo dos indivíduos para os empregos oferecidos pela baixa escolaridade e por não terem domínio de conhecimentos tecnológicos específicos para atender às exigências das indústrias e dos serviços. Sem perspectiva de inserção nos processos de trabalhos com registro em carteira, remuneração digna e benefícios, os indivíduos são levados a se inserir em trabalhos precários ou subemprego. A possibilidade de moradia passa a ser em locais com custo baixo ou mesmo em situações irregulares. Esta situação pode ser observada em territórios periféricos do próprio município de Curitiba, como também nos municípios da região metropolitana.

Ao estudar a realidade demográfica, socioeconômica e política do Paraná, dos anos 70 aos anos 90, o IPARDES (2004b) encontrou modificações na distribuição da população nas zonas rurais e urbanas. Segundo os dados, a população rural do Estado foi reduzida a menos da metade no período. O Instituto refere que no início do período (1970) O IBGE descreveu a população rural com 4.450 .783 pessoas e, no ano 2000 esta passou a ser representada por 1.777.374 pessoas. Esse movimento de migração também foi 
percebido no Brasil ao longo do mesmo período. A migração da população rural e do interior dos Estados brasileiros é um fenômeno atribuído às mudanças no modelo de produção em todo o país descrito como a implementação da mecanização no campo e o crescimento de polos industriais em determinadas regiões, entre as quais se encontra o município de Curitiba e municípios da região metropolitana.

[...] a inserção na economia globalizada e a absorção do novo padrão de acumulação baseado na flexibilização produtiva, este caracterizado por mudanças profundas no paradigma tecnológico vigente na fase fordista, aprofundaram e transformaram o nexo entre as dinâmicas urbana (espacial) e econômica. A interconexão global entre os mercados cambiais e financeiros e o aprofundamento da internacionalização produtiva; a reorganização do modelo empresarial e tecnológico, a formação de redes empresariais e a tendência à terceirização trouxeram importantes mudanças nos padrões locacionais. O novo padrão de acumulação, alicerçado em um fluxo contínuo de inovações tecnológicas e demanda de novos serviços, exige que as cidades adaptem sua infraestrutura e seu meio socioprofissional como condição para o desenvolvimento da base material. A presença ou ausência desses requisitos implicará a constituição de pólos dinâmicos da economia globalizada ou a relegará à concentração de atividades de baixa qualificação, realimentando um processo de causação circular, no qual a degradação econômica, social e ambiental é reiterada (Nojima; Moura; Silva, 2004, p.1).

Quanto ao número de domicílios (2.132,60), nos 399 municípios do Estado do Paraná, atendidos com saneamento básico, água tratada e coleta de esgoto, pela Companhia de Saneamento do Paraná (SANEPAR) no ano 1999 teve-se que a quase totalidade (2.072,90 domicílios) recebia água tratada, mas nem a metade recebia a coleta de esgoto (794,7 domicílios representando $38,34 \%$ dos domicílios). Mesmo com esses índices, cabe destacar que a situação registrada em 1999 apresentou avanço com relação à situação que se tinha em anos anteriores, na qual a cobertura de esgoto tratado era ainda menor. Quanto ao crescimento na distribuição de energia elétrica nos domicílios urbanos, os dados apresentam que esta é uma situação que avançou na década de 1990, pois o número de domicílios registrados com energia no Estado cresceu 134\%. Porém, nos domicílios rurais a situação se manteve praticamente inalterada, ou seja, sem crescimento de domicílios com energia desde anos anteriores. Contraditoriamente ao quadro apresentado, o Estado do Paraná vem aumentando a sua produção 
de energia elétrica, assim como o aumento consumo per capita (kwh por habitante), sendo o município de Curitiba aquele que apresenta o maior índice de consumo de energia em domicílios, comércio e serviços e setor industrial (IPARDES, 2004b).

Ao analisar o perfil das famílias pobres no Paraná, com base nos dados do Censo 2000 do IBGE, caracterizando-as segundo classe social e meio, rural ou urbano, sendo classe social compreendida pela renda per capita (até $1 / 2$ sal mim, de $1 / 2$ sal mim a 1 sal mínimo e acima de 1 salário mínimo), teve-se como resultados que para famílias de classe social com maior poder aquisitivo (renda per capta acima de 1 salário mínimo) a queda na taxa de natalidade foi mais acentuada, assim como o aumento na expectativa de vida, principalmente para as pessoas que viviam em centros urbanos. Para as famílias de classe social com menor poder aquisitivo (renda per capta abaixo de 1/2 salário mínimo) observou-se menor queda na taxa de natalidade e pouca diferença na expectativa de vida ao longo destes anos principalmente na população moradora da zona rural (IPARDES, 2003). Estudo sobre mudanças na distribuição da população do Paraná, segundo os censos demográficos de 1991 e 2000, verificou discreta queda na taxa de natalidade e aumento significativo de população idosa (de 70 anos e mais) (IPARDES, 2004b).

\subsubsection{Educação, emprego e renda}

Com relação ao índice de analfabetismo na população de 15 anos e mais, no período de 1992 a 1999, o Paraná apresentou índices menores que o Brasil e maiores que os índices referentes à Região Sul. No ano de 1999 os dados registraram $13,33 \%$ de analfabetos na população acima de 15 anos no Brasil, na Região Sul 7,76\% e no Paraná 10,15\% (IPARDES, 2004b). Em alguns municípios da região metropolitana de Curitiba, esses índices tendem a ser mais altos quando se estuda o segmento da população de 60 anos e mais. Acredita-se que o fenômeno da migração trouxe para estes espaços urbanos 
trabalhadores rurais que não tiveram acesso à educação. Esta condição Ihes dificultou tanto a inserção no trabalho como as tomadas de decisões sobre sua própria vida, por não conseguirem compreender os processos determinantes de suas realidades e agirem no sentido de transformá-las.

Sobre as estatísticas de renda e emprego no Estado do Paraná foi observado pequeno aumento nas atividades nos setores de produção primária, indústria, comércio/serviços, no período de 1994 a 1999. Outro dado relevante foi que a participação do PIB paranaense no PIB brasileiro aumentou no período de 1991 a 2000, de 5,87 para 6,52. Quanto à distribuição da população ocupada, segundo o setor de atividade, no período de 1992 a 1999 (exceto o ano de 1994 que não houve registro), foi observado aumento de ocupação no setor de serviços e indústrias, porém o setor de produção agrícola apresentou queda no número de ocupação, coerente com o cenário descrito anteriormente sobre a produção agroexportadora (IPARDES, 2004b).

Nesse caso, a situação que foi apresentada anteriormente demonstra a contradição do aumento da produção com a queda no número de empregos, porém, reforça o fenômeno típico da política econômica que estimula o aumento no emprego da tecnologia para a produção no campo. Outra questão é que, no período referido, a população economicamente ativa acima de 15 anos cresceu no Estado do Paraná e os registros de contribuintes com a Previdência Social tiveram aumento menor que o esperado. Logo, acredita-se que o aumento do número de pessoas economicamente ativas acima de 15 anos estava representado por pessoas sem ocupação ou com emprego sem carteira assinada. Em dados analisados pelo IPARDES em 1999, em população urbana, foi apontado que o déficit de postos de trabalho no Estado era maior que o número de contribuintes da previdência social no mesmo período (IPARDES, 2004b). 


\subsubsection{Indicadores epidemiológicos}

Com relação à mortalidade infantil os dados mostraram que este índice teve significativa queda no período de 1979 a 20005, tanto no Brasil como no Paraná e Curitiba. O Brasil tinha um índice, em 1979, de 85 óbitos por 1000 nascidos vivos e em 2000 apresentou índice de 34,6 óbitos por 1000 nascidos vivos; o Paraná, em 1979, apresentou índice de 56,35 óbitos por 1000 nascidos vivos e em 2000 o índice caiu para 19,48 óbitos por 1000 nascidos vivos; Curitiba que tinha índice de 47,32 óbitos por 1000 nascidos vivos em 1979 teve registrado em 2000 14,71 óbitos por 1000 nascidos vivos. O estudo mostrou também que em 2004 os índices ficaram menores para o Paraná que apresentou 15,41 óbitos por 1000 nascidos vivos e para Curitiba com 11,16 óbitos por 1000 nascidos vivos. Não houve registro sobre os dados no Brasil neste último período (Paraná, 2009a; IPPUC, 2008).

Em estudo da Secretaria de Saúde do município de Curitiba sobre mortalidade infantil, neonatal e pós-neonatal, no período de 1996 a 2006, encontram-se dados que demonstram a queda de $46 \%$ do coeficiente de mortalidade infantil no município, este passou de 18,05 (1996) para 10,34 (2006) óbitos por 1000 nascidos vivos. E o maior coeficiente de morte foi relacionado às 'afecções do período perinatal'. Esta é a maior causa de mortalidade infantil em todo o período, apesar de apresentar queda de 51,7\%. As principais medidas de prevenção de óbitos infantis reduzíveis identificados pelo Comitê Pró-vida de Prevenção da Mortalidade Materna e Infantil foram ações de educação em saúde, seguida de ações de planejamento familiar e adequada assistência quanto ao diagnóstico e tratamento (Curitiba, 2007a).

\footnotetext{
5 O período utilizado na análise é longo e ultrapassa o tempo das Conferências estudadas, mas permite evidenciar a evolução do índice ao longo de mais de duas décadas que são coincidentes com a implantação das diretrizes preconizadas pelo movimento da Reforma Sanitária Brasileira e implantação do SUS.
} 
Quanto ao índice de mortalidade materna em Curitiba, a tendência de queda se confirmou no período de 1982 a 2003, em 1982- 57,2/100.000 nascidos vivos e em 2003-32,2/100.000 nascidos vivos. Apesar da queda, o índice ficou acima do recomendado pela Organização Mundial de Saúde (10 a 20/100.000 nascidos vivos). Os dados dos anos 90 registraram oscilação do índice com aumento de óbitos maternos inicialmente e, na sequencia, diminuição. Este fenômeno pode ser atribuído tanto ao aumento de número de óbitos como à melhora no sistema de registros e mudanças nos critérios epidemiológicos para a caracterização do óbito materno (IPPUC, 2008). No Paraná os índices de mortalidade materna, apresentados na série histórica de 1990 a 2000, mostraram queda de $36 \%$. O estudo aponta que, em 1990 , o coeficiente de mortalidade era de 105 óbitos/100.000 nascidos vivos e em 2000 foi de 67 óbitos/100.000 nascidos vivos. Apesar do índice elevado, fora dos padrões recomendados pelos organismos internacionais de saúde, a queda de $36 \%$ foi relacionada ao trabalho de 22 Comitês Regionais de Prevenção da Mortalidade de Mortalidade Materna que investigou todas as mortes de mulheres em idade fértil para identificar as causas e os fatores determinantes e recomendar medidas de prevenção a serem adotadas nos serviços de saúde (Paraná, 2009b).

Estudo que analisou as principais causas de mortes de mulheres de 10 a 49 anos no Brasil no período de 2000 a 2005 apontou as dez causas principais. O primeiro lugar das causas foi identificado como sendo doenças cerebrovasculares (7,5 óbitos/100.000 hab.) e na sequência vieram: acidente de transporte terrestre (7,0 óbitos/100.000 hab.), homicídios (5,3 óbitos/100.000 hab.), HIV (5,0 óbitos/100.000 hab.), neoplasia maligna da mama (4,5 óbitos/ 100.000 hab.), doenças isquêmicas do coração (4,4 óbitos/100.000 hab.), neoplasias malignas de útero (3,6 óbitos/100.000 hab.), gravidez, parto e puerpério (2,7 óbitos/100.000 hab.), influenza e pneumonia (2,5 óbitos/ 100.000 hab.) e diabetes (2,4 óbitos/100.000 hab.) (Brasil, 2007).

Nos dados de óbitos no Paraná no ano de 2000, os registros sobre mortalidade geral, em números absolutos, indicaram que a primeira causa de óbito era o Infarto Agudo do Miocárdio com 4.434 mortes, seguida de: acidente vascular cerebral com 3.224 mortes; outras doenças pulmonares 
obstrutivas crônicas com 2.523 mortes; insuficiência cardíaca com 2.272 mortes e em quinto lugar com 1.981 mortes o diabetes mellitus. Outro dado que chama atenção nestes registros é que 1.746 mortes foram registradas como "morte sem assistência", ou seja, nesses casos não se teve registro das causas de mortes (IPPUC, 2008).

Segundo a Secretaria Municipal de Saúde de Curitiba (2005a) as cinco principais causas de óbito na população, no ano de 2003, foram: infarto agudo do miocárdio (785 mortes - 8,4\% do número total de óbitos); agressão disparo de arma de fogo (367 mortes - 3,9\% do número total de óbitos); outras doenças pulmonares obstrutivas crônicas (358 mortes - 3,8\% do número total de óbitos); diabetes mellitus NE (332 mortes - 3,6\% do número total de óbitos) e doença isquêmicas crônica do coração (324 mortes - 3,5\% do número total de óbitos).

Na faixa etária de 1 a 14 anos, a principal causa de óbito foi 'causas externas de morbidade e mortalidade', com $39,2 \%$ das mortes do grupo, e esta foi também a principal causa nos grupos de 15 a 24 anos $(79,7 \%)$, de 25 a 34 anos $(58,5 \%)$ e de 35 a 44 anos $(28,5 \%)$. Nos grupos seguintes os registros demonstraram que a principal causa de morte voltou a ser as 'doenças do aparelho circulatório' para os indivíduos nas faixas etárias de 45 a 54 anos (30,3\%), de 55 a 64 anos (36\%) e acima de 65 anos (43\%) (Curitiba, 2005a).

Cabe destacar que, se fossem somados todos os óbitos por neoplasias, pois os registros identificam a neoplasia por localização no corpo - brônquios e pulmões, mama, estômago e colon, esta seria a segunda principal causa de óbito na população ( 621 mortes $-6,66 \%$ do número total de óbitos), mantendo a primeira causa - infarto agudo do miocárdio (Curitiba, 2005a).

Em estudo posterior, a própria Secretaria Municipal de Saúde (Curitiba, 2007a) chama a atenção para a necessidade do desdobramento desses dados e aponta que no período de 1980 a $2005^{6}$ houve aumento da proporção dos óbitos por neoplasias na mortalidade geral, pois o índice passou de $13,1 \%$ para $19,7 \%$ do total dos óbitos, sendo que a faixa etária

\footnotetext{
6 Dados preliminares.
} 
mais atingida ficou entre 50 a 79 anos e o número de óbitos foi maior foi de indivíduos do sexo masculino, mas as mulheres foram atingidas mais precocemente (15 a 49 anos). Quanto à localização da neoplasia no grupo do sexo feminino teve-se que as mais comuns foram mama e colo de útero e no homem o câncer de próstata, mas neste caso aparecendo mais tardiamente.

Para a Secretaria Municipal de Saúde (Curitiba, 2008b), as causas externas representaram importante causa de morbimortalidade nos dados epidemiológicos dos últimos anos, pois foi terceira causa de internação no Sistema Único de Saúde no ano de 2006 e também a terceira causa de morte no mesmo ano (14,8\% do total de óbitos), sendo o grupo populacional mais atingido no ano os de 15 a 29 anos do sexo masculino. As causas de mortes que ficaram em primeiro e segundo lugar em 2006 seguiram os anos anteriores e foram doenças circulatórias e neoplasias, respectivamente.

No desdobramento dos dados destacou-se que, no período de 1980 a 2006, houve aumento significativo das mortes por homicídio, passando de 7,9 para 38,9 óbitos por 100.000 habitantes e o objeto mais utilizado para o homicídio foi a arma de fogo. $\mathrm{Na}$ análise da mortalidade proporcional por causas externas, segundo o tipo de causa em 2006, o homicídio representou $48,3 \%$ das mortes por causas externas, seguido de acidente de transporte com $26,1 \%$, quedas com $8,4 \%$, suicídios com $6,6 \%$, outros $5,1 \%$, indeterminados $3,2 \%$ e afogamentos com $2,2 \%$.

Nos registros de atendimento às vítimas de violência no município, no período de 2003 a 2006, verificou-se que do total de 2.687 casos notificados $91,8 \%$ das vítimas eram do sexo feminino e 8,2 do sexo masculino. A violência sexual foi a primeira causa de violência contra a mulher, seguida da violência física, verbal/moral e psicológica. Quanto à violência contra criança e adolescentes, os dados das notificações do ano de 2006 mostraram que foram realizadas 3.390 notificações e nestas houve um ligeiro predomínio de vítimas do sexo masculino (1.699 vítimas masculinas e 1.659 vítimas do sexo feminino). A faixa etária predominante foi de 5 a 9 anos. $O$ maior número de notificações foi realizado pela Fundação da Ação Social (FAS), seguida das escolas municipais, hospitais e unidades de saúde. A violência intrafamiliar foi predominante ( $90 \%$ dos casos) e, com relação à natureza das 
que ocorreram no domicílio, a negligência teve o maior índice representando $61,7 \%$ dos casos. Nos casos de violência extrafamiliar (10\% dos casos) a natureza da violência mais predominante foi sexual, representada em $66,6 \%$ dos casos (Curitiba, 2008b).

No Paraná foi desenvolvido estudo denominado "Mapa do Crime" que analisou quantitativamente a distribuição e a natureza de crimes nos cinco maiores municípios do Estado baseado nos registros de ocorrência na Polícia Militar e Civil. As ocorrências registradas no período de $1^{\circ}$ a 31 de julho de 2003 foram analisadas e distribuídas segundo dados populacionais e referência geográfica do local do evento. Os municípios estudados foram: Curitiba, Londrina, Maringá, Foz do Iguaçu e Ponta Grossa. Para a análise, os eventos foram considerados segundo os de maior impacto e maior ocorrência nos grandes grupos - homicídio, lesão corporal, estupro, estelionato, extorsão/ sequestro, tráfico, furto/roubo de veículos, furto e roubo (Paraná, 2003). Ainda, em outro estudo intitulado "Vitimização de violência" baseado na metodologia da pesquisa qualitativa, buscou-se verificar a percepção do cidadão sobre os fenômenos da violência em três cidades paranaenses (Paraná, 2007).

Os resultados dos estudos referidos demonstraram que no Estado, assim como em Curitiba, os tipos de violência mais registrados e mencionados por munícipes entrevistados foram aquelas que estavam relacionadas à lesão do patrimônio, no caso furto e roubo. Em Curitiba, os locais das ocorrências concentraram-se na região central da cidade. Pela análise dos autores, esta incidência se deveu à área geográfica com maior concentração de atividades comerciais e maior trânsito de pessoas. Dentre os cinco municípios estudados, Curitiba foi o município com maior percentual do total de registro das ocorrências selecionadas $(70,4 \%)$, seguido de Maringá $(9,4 \%)$, Londrina (9,1\%), Ponta Grossa (6,3\%) e Foz do Iguaçu (4,8\%) (Paraná, 2003, p.20).

Para a análise sobre o local da ocorrência no estudo houve perda de dados por problemas do sistema e registros. Assim, somente $57,6 \%$ dos registros policiais em malha urbana de Curitiba foram geoprocessados. Nos dados registrados teve-se que a maioria $(72 \%)$ das ocorrências foi em bairros considerados não violentos da cidade. Segundo os relatórios das pesquisas 
este fenômeno - classificar bairros como não violentos - se deve ao próprio critério preestabelecido para a classificação do grau de violência no território, pois nestes critérios os crimes de homicídio são considerados de maior violência e de menor violência aqueles relacionados ao patrimônio. Portanto, coerente neste caso, pois nas ocorrências registradas o evento estava relacionado a danos ao patrimônio.

Pela percepção do cidadão sobre o crime na cidade de Curitiba, considerando somente eventos ocorridos no período de 12 meses anteriores ao momento da entrevista, o furto foi a ocorrência mais citada pelos entrevistados $(12,8 \%)$ e a maioria $(59,9 \%)$ dos entrevistados referiu que não fez ocorrência policial porque não acreditava que as instituições policiais teriam soluções para eles. A sensação de insegurança do entrevistado ficou relacionada ao tempo transcorrido da ocorrência, ou seja, quanto menor o tempo transcorrido maior era a sensação de insegurança. A percepção de risco na comunidade variou. Quando o indivíduo tinha sido vítima a percepção era maior, quando a vítima era outra pessoa a percepção de risco para ocorrências era menor. Uma questão apontada pelo estudo a ser destacada é sobre a sensação de risco para ocorrências com policiais, agressão ou extorsão. No estudo foi identificado que a sensação era maior para o grupo de entrevistados com renda inferior a 11 salários mínimos (Paraná, 2007).

A medida de segurança adotada mais citada pelos entrevistados foi instalação de equipamentos de segurança nos domicílios. Quanto à organização das comunidades para reduzir a violência, os entrevistados, na maioria (90\%), disseram desconhecer ações nesse sentido em sua vizinhança. Nos casos que referiram conhecer adoção de medidas para reduzir a violência (10\% dos entrevistados) indicaram as organizações comunitárias. As instituições mais citadas foram: igreja, moradores da vizinhança, associação de bairro, conselho de segurança comunitária, ONGs e associações políticas. Entre os entrevistados que apontaram que a segurança é feita por moradores voluntários da vizinhança (3\%) uma parte significativa $(2,5 \%)$ referiu que esta segurança é realizada por gangues ou pessoas ligadas ao tráfico de drogas (Secretaria de Estado de Segurança Pública, Paraná, 2007). 
A percepção do entrevistado sobre fatos relacionados a crimes e o nível de desordem social em sua vizinhança também foram temas de interesse do estudo. $\mathrm{E}$ os dados apontados mostraram que a percepção era maior para os entrevistados moradores de bairros mais violentos do que os moradores dos bairros menos violentos. Assim, identificou-se que $75 \%$ dos moradores de áreas violentas já presenciaram ou ouviram falar de crianças e adolescentes vítimas de violência pelos pais. Assassinatos na vizinhança foram referidos por $51,61 \%$ de entrevistados moradores de áreas violentas e $27,94 \%$ por aqueles de áreas não violentas. Agressão física contra mulheres pelos maridos foi referida por $40,38 \%$ dos entrevistados moradores de áreas violentas e por $27,94 \%$ dos moradores de áreas não violentas. Por fim, a violência sexual foi referida por $26,92 \%$ dos entrevistados moradores de áreas violentas e por $14,80 \%$ dos moradores de áreas não violentas (Paraná, 2007).

Ao analisar os dados disponíveis pelo IPPUC (2005) sobre segurança e índices de mortalidade por causas externas na Regional Boa Vista, no período de 1997 a 2001, pode-se afirmar que o bairro com o pior desempenho no período foi o Tarumã. Este foi também o primeiro bairro em registros de homicídios na regional no período de 1999 a 2000. O segundo bairro em número de registros desta ocorrência foi o Taboão. Este desempenho ruim segue ainda quando se analisam os dados sobre o atendimento da polícia militar em ocorrências no período de 1999 a 2000, o Tarumã é novamente aquele que detém as maiores taxas. Em relação aos acidentes de trânsito atendidos pelo Serviço Integrado de Atendimento ao Trauma em Emergência (SIATE) no ano 2000, o Bairro Alto registrou os maiores índices e foi seguido pelos bairros: Santa Cândida, Boa Vista e Bacacheri (IPPUC, 2005).

Com relação às oito causas com maior incidência no internamento hospitalar no município de Curitiba pelo Sistema Único de Saúde (SUS), no período de 1995 a 2002, teve-se como a principal causa a gravidez/parto e puerpério. Observa-se, ainda, que esta é a causa de quase $20 \%$ dos internamentos em todos os anos do período estudado. As outras causas com incidências mais significativas foram: doenças do aparelho circulatório, do aparelho digestivo, do aparelho respiratório, do aparelho geniturinário, neoplasias e causas externas (IPPUC, 2008). 
Ao se pesquisar sobre a distribuição dos leitos utilizados com as Autorizações de Internamento Hospitalar (AIH) pelo Sistema Único de Saúde em 1996 no município de Curitiba, observou-se que a rede de serviços foi também utilizada por usuários moradores de municípios da região metropolitana de Curitiba, assim como por usuários moradores de outros municípios do interior do Paraná, de outros estados ou países, como demonstrados na Figura 3 a seguir.

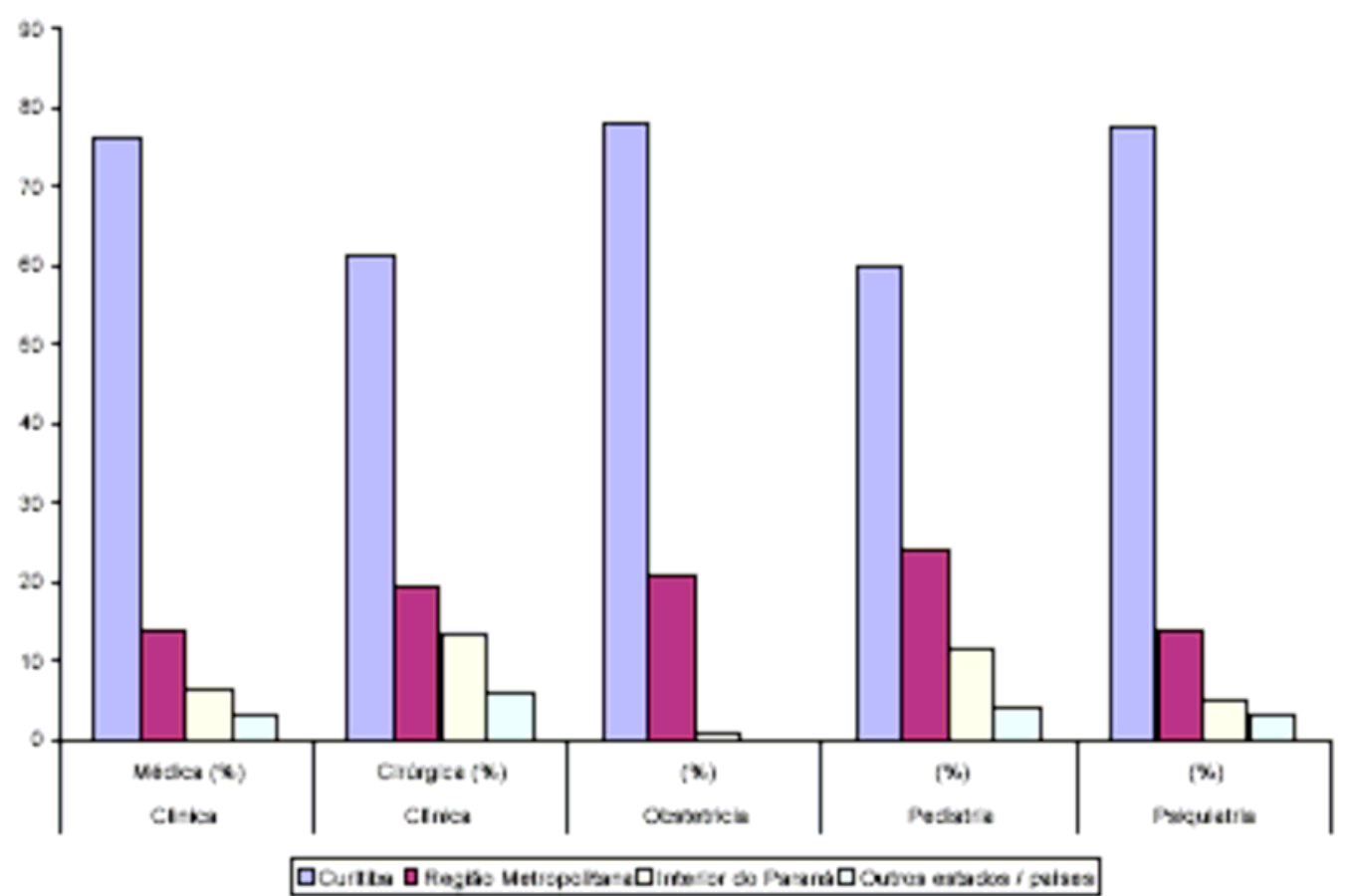

Figura 3 - Distribuição do percentual das AlHs, por especialidade e procedência do usuário nos Fonte: IPPUC (2008)

Quanto aos dados epidemiológicos sobre o HIV/Aids no município, teve-se no período de 1984 a $2002^{7}$ um significativo aumento na incidência, mas com melhora no enfrentamento ao agravo, pois os registros mostraram incidência de 0,09 e letalidade de 100\% em 1984 e, em 2002 se teve 18,42 de incidência, porém, a letalidade registrada foi de 17,60\%. Essas mudanças

7 O estudo apresentou dados preliminares - até novembro de 2002. 
no fenômeno se deveram às Políticas Públicas adotadas no Brasil para o enfrentamento do agravo em questão. Nas diretrizes das Políticas Públicas para o enfrentamento do HIVIAIDS as ações foram norteadas para prevenção da contaminação pelo HIV e, para os doentes, se garantiu a distribuição de medicamentos na rede pública de serviços de saúde, estímulo para a adesão à assistência medicamentosa e medidas de proteção para os portadores do HIV (IPPUC, 2008).

\begin{abstract}
O total de casos de AIDS notificados em Curitiba de 1984 a dezembro de 2005 é de 6.762 pacientes sendo 4.706 do sexo masculino e 2.056 do sexo feminino. A proporção de casos segundo sexo vem diminuindo, com a evolução da epidemia, passando de 10 homens para 1 mulher em 1986, para nos últimos 5 anos, 2 casos em homens para 1 mulher. Esta mudança na relação, chamada de feminilização epidemia, é observada não só em Curitiba como no Brasil [...] (Curitiba, 2006a, p.3).
\end{abstract}

Em estudo que analisou a distribuição dos casos de AIDS em Curitiba, registrados no período de 1984 a 2005, teve-se que, na distribuição por faixa etária, $67 \%$ dos casos registrados no período se encontravam em indivíduos com idade entre 20 e 40 anos, adultos jovens. Outras questões apontadas: nos anos de 2003 a 2005 houve deslocamento da doença para indivíduos de idades mais avançadas, neste caso o estudo atribuiu o fenômeno ao sucesso das medidas de prevenção da transmissão vertical (mãe-filho) que foram implantadas pelo Programa Mãe Curitibana; a epidemia se deslocou para a população com menor escolaridade e o número de casos em indivíduos com mais de oito anos de escolaridade teve queda e, por último, o número óbitos (2.323) dos portadores AIDS representou $34,5 \%$ do total de casos registrados (6.762 pacientes) ao longo dos anos estudados, sendo que a proporção de doentes para o número de óbitos nos períodos agrupados para o estudo teve queda significativa. No estudo não se analisou a sobrevida dos doentes, mas com os índices apresentados pode-se afirmar que houve aumento ao longo dos anos estudados (Curitiba, 2006a).

Em série histórica a Secretaria Municipal de Saúde (Curitiba, 2006b, p.8) apresenta o número de casos e coeficiente de incidência por 100.000 
habitantes de agravos de notificação obrigatória no período de 2000 a $2006^{8}$. Nestes tem-se que o coeficiente dos acidentes por animais peçonhentos variam no período, sendo que em 2006 foi registrado o menor índice, 122,33 por 100.000 hab., e o maior foi em 2004, com 254,12 por 100.000 hab. Nos registros de atendimentos antirrábicos percebe-se elevação inicial e a seguir queda em todos os anos seguintes na incidência. Assim, o maior índice foi em 2001 com 517,10 por 100.000 hab. e o menor em 2006 com 346,76 por 100.000 hab., porém destaca-se que o ano de 2006 ainda não se tinha os dados completos. A dengue, doença que tem sido objeto de campanhas nacionais e locais, mostrou comportamento variado inicialmente, as oscilações dos índices foram significativas e somente em 2002 registraram-se dois casos autóctones, sendo que o restante foi de casos importados. Portanto, a maior incidência foi em 2002 com 9,12 por 100.000 hab. e em 2004 a menor com 0,35 por 100.000 hab.

Os casos de hanseníase foram apresentados na relação de casos novos para 10.000 hab. $\mathrm{Na}$ incidência se vê queda contínua em todo o período, sendo que no início do período (2000) a incidência era de 0,77 por 10.000 hab. e no final (2006) era de 0,24 por 10.000 hab. Em relação à incidência da hepatite viral se pode ver queda acentuada nos índices até o ano de 2005 , quando se tem registro de aumento da incidência $(33,45$ por 100.000 hab.), mas em 2006 a tendência de queda volta a ser registrada, e assim se teve que a incidência em 2000 foi de 64,51 e em 2006 de 10,96 por 100.000 hab (Secretaria Municipal de Saúde, Curitiba, 2006b: 8).

O registro da incidência da leptospirose mostrou oscilações em todo o período estudado, sendo a maior incidência em 2005 com 7,62 por 100.000 hab. e, em 2006 o registro foi de 5,79 por 100.000 hab. A incidência de Meningite também foi oscilante e o maior índice foi no ano de $2006 \mathrm{com}$ 71,34 por 100.000 hab., sendo que no ano de 2004 foi registrada a menor incidência 32,75 por 100.000 hab.. Os dados analisados mostraram que no

\footnotetext{
8 Dados preliminares.
} 
ano de 2003 não se registrou nenhum caso de coqueluche e em 2004 a incidência foi de 0,12 por 100.000 hab. e em 2006 a incidência foi de 0,06 por 100.000 hab. A rubéola teve em 2000 a incidência de 0,76 por 100.000 hab. Em 2003 e 2004 não houve registro de casos, mas em seguida voltou a ter registro de casos e ficou nos anos de 2005 e 2006 com a incidência de 0,06 por 100.000 hab. $O$ sarampo não teve nenhum caso registrado no período estudado (Curitiba, 2006b, p.8).

A incidência da sífilis congênita teve oscilações no período, analisada na razão de caso por 1.000 nascidos vivos, a doença registrou a maior incidência no ano de 2000 (4,72 por 1.000 nascidos vivos), a menor em 2005 (1,04 por 1.000 nascidos vivos) e em 2006 a incidência foi de 1,06 por 1.000 nascidos vivos. No registro de sífilis na gestante, na razão de casos por 1.000 nascidos vivos, a maior incidência foi no primeiro ano (2000) com 7,48 por 1.000 nascidos vivos e em seguida com tendência de queda contínua, terminando o período, 2006, com registro de 3,13 por 1.000 nascidos vivos. A incidência de tétano acidental teve aumento para posterior queda, no ano 2000 não se teve nenhum caso registrado, em 2001 a incidência foi de 0,18 por 100.000 hab.. Em 2006 o registro foi de 0,06 por 100.000 hab. Houve oscilação na incidência da tuberculose, casos novos por 100.000 hab., no período estudado, sendo que a maior incidência foi no ano de $2002 \mathrm{com}$ 36,30 por 100.000 hab. e a menor incidência em 2006 com 23,30 por 100.000 hab. (Curitiba, 2006b, p.8).

Nos registros de casos confirmados de doenças de notificação obrigatória, segundo Distrito Sanitário de Curitiba, no ano de 2006 o Distrito Boa Vista teve 26 caso de hepatite viral dos 196 casos registrados em Curitiba. Registrou 01 caso novo de hanseníase e no município foram 43 casos novos registrados; 61 casos novos de tuberculose e, o município teve o total de 417; 40 casos de AIDS adulto e o município 249; 01 caso de AIDS em criança, sendo que o município teve 02 no total; 07 casos de AIDS em gestante e no município ocorreram 29 casos no total; 02 casos de toxoplasmose em gestante dos 42 casos registrados no município; 01 de toxoplasmose congênita sendo que o município teve 02 no total; 04 casos de sífilis congênita e no município o registro apontou 34 casos ao todo; 10 casos de sífilis em gestante e no 
município o registro foi de 85 casos; 01 de caso importado de dengue e no município foram registrados $06 ; 1.027$ atendimentos antirrábicos e o município teve 6.202 ao todo; 66 ocorrências toxicológicas e o município teve 1.046 ao todo; 528 acidentes com animais peçonhentos e o município teve 2188 ao todo, 13 casos de leptospirose dos 92 casos registrados no município e, por fim, 17 casos de doença meningocócica de 90 casos registrados no município (Curitiba, 2006b, p.8).

Com relação à cobertura vacinal em menores de um ano, no município de Curitiba, no período de 1984 a 2006, apresentado a seguir na Tabela 1, na qual se observam oscilações nos índices de cobertura no caso da vacina antisarampo no início do período com índices acima de $80 \%$ de cobertura e posteriormente com valores que chegariam a ultrapassar $100 \%$, neste caso pelos dados populacionais sobre os menores de 01 ano ser diferente nos Institutos de Pesquisa. Mesmo com índices nos parâmetros recomendados pelo Ministério da Saúde houve registro de 502 casos em 1998, o maior número de casos da doença registrados no período. Ao refletir sobre este fenômeno poderia se levantar a hipótese da relação do aumento do número de casos no período pela baixa cobertura vacinal em períodos anteriores (IPPUC, 2008).

No caso da vacina BCG o índice de cobertura foi elevado (acima de $100 \%$ ) e pode-se afirmar que a captação do usuário nos primeiros dias de vida para tomar a vacina facilita a manutenção da cobertura vacinal, pois a intervenção ocorre articulada à assistência à gestante, puérperas e ao bebê nos primeiros dias de vida, orientando a população sobre a importância da vacina. Outra hipótese sobre a cobertura vacinal ter ficado, quase todo o período, acima de $100 \%$ para a população menor de um ano de Curitiba é que o município é o maior da mesorregião metropolitana e parte da população da região, dos territórios municipais próximos, acaba utilizando a rede de serviços de saúde desta cidade conforme aponta a própria nota sobre os dados populacionais utilizados. 
Tabela 1 - Cobertura vacinal de rotina em população menos de um ano, segundo o tipo de vacina aplicada, no período de 1984 a 2006, em Curitiba-PR

\begin{tabular}{|c|c|c|c|c|c|c|c|c|c|c|c|c|c|c|c|}
\hline \multirow{3}{*}{ Ano } & \multirow{3}{*}{$\begin{array}{l}\text { População } \\
\text { menor de } 1 \\
\text { ano }\end{array}$} & \multicolumn{14}{|c|}{ Vacinados menores de 1 ano } \\
\hline & & \multicolumn{2}{|c|}{ Anti-sarampo } & \multicolumn{2}{|c|}{ BCG } & \multicolumn{2}{|c|}{ Tríplice } & \multicolumn{2}{|c|}{ Sabin } & \multicolumn{2}{|c|}{ Hep. B (dose 3) $)^{(1)}$} & \multicolumn{2}{|c|}{ HI B (dose 3) ${ }^{(2)}$} & \multicolumn{2}{|c|}{ Tetravalente ${ }^{(2)}$} \\
\hline & & Abs. & $\%$ & Abs. & $\%$ & Abs. & $\%$ & Abs. & $\%$ & Abs. & $\%$ & Abs. & $\%$ & Abs. & $\%$ \\
\hline 1984 & 34.200 & 28.085 & 82,12 & 40.483 & 118,37 & 25.147 & 73,53 & 23.566 & 68,88 & - & - & - & - & - & - \\
\hline 1985 & 35.033 & 29.521 & 81,93 & 38.717 & 107,45 & 27.681 & 76,82 & 26.292 & 72,97 & - & - & - & - & - & - \\
\hline 1986 & 35.201 & 28.840 & 81,93 & 32.606 & 92,63 & 25.580 & 72,67 & 25.159 & 71,47 & - & - & - & - & - & - \\
\hline 1987 & 36.288 & 31.774 & 87,56 & 34.202 & 94,25 & 26.620 & 73,36 & 28.126 & 77,51 & - & - & - & - & - & - \\
\hline 1988 & 37.399 & 28.803 & 77,02 & 38.015 & 101,55 & 29.104 & 77,82 & 29.639 & 79,25 & - & - & - & - & - & - \\
\hline 1989 & 38.433 & 29.744 & 77,39 & 42.266 & 109,97 & 30.182 & 78,53 & 30.409 & 79,12 & - & - & - & - & - & - \\
\hline 1990 & 32.179 & 28.857 & 80,68 & 38.392 & 110,31 & 27.968 & 86,88 & 27.502 & 85,47 & - & - & - & - & - & - \\
\hline 1991 & 34.008 & 31.352 & 92,19 & 39.824 & 117,10 & 28.323 & 89,28 & 28.790 & 84,66 & - & - & - & - & - & - \\
\hline 1992 & 27.712 & 24.755 & 80,33 & 33.335 & 120,29 & 24.615 & 88,82 & 24.697 & 89,12 & - & - & - & - & - & - \\
\hline 1993 & 29.671 & 27.629 & 93,12 & 36.593 & 123,33 & 26.638 & 80,78 & 27.190 & 91,64 & - & - & - & - & - & - \\
\hline \multirow{2}{*}{1994} & ${ }^{(3)} 29.273$ & 27.940 & 94,10 & 38.541 & 129,80 & 26.881 & 90,50 & 27.177 & 91,50 & - & - & - & - & - & - \\
\hline & ${ }^{(4)} 29.944$ & & 107,70 & - & 148,50 & - & 103,60 & - & 104,70 & - & - & - & - & - & - \\
\hline \multirow{2}{*}{1995} & ${ }^{(3)} 29.273$ & 25.127 & 89,20 & 32.250 & 110,10 & 25.068 & 85,60 & 25.334 & 86,50 & - & - & - & - & - & - \\
\hline & ${ }^{(4)} 29.860$ & & 97,20 & & 120,10 & & 93,30 & & 94,30 & - & - & - & - & - & - \\
\hline \multirow{2}{*}{1996} & ${ }^{\left({ }^{3}\right)} 28.470$ & 25.692 & 90,20 & 27.911 & 98,00 & 26.185 & 91,90 & 25.754 & 90,40 & - & - & - & - & - & - \\
\hline & ${ }^{(4)} 27.028$ & - & 96,00 & - & 103,20 & - & 96,80 & - & 95,20 & - & - & - & - & - & - \\
\hline \multirow{2}{*}{1997} & ${ }^{(3)} 28.397$ & 28.012 & 98,64 & $34 . .398$ & 121,13 & 28.207 & 99,33 & 29.361 & 103,90 & - & - & - & - & - & - \\
\hline & (4) 28.135 & & 99,50 & & 122,20 & & 100,20 & & 104,30 & - & - & - & - & - & - \\
\hline \multirow{2}{*}{1998} & (3) 29.028 & 32.311 & 111,30 & 30.102 & 103,70 & 28.020 & 96,50 & 29.032 & 100,00 & 11.642 & 40,10 & 31.642 & 109,10 & - & - \\
\hline & ${ }^{(4)} 26.695$ & & 121,00 & & 112,80 & - & 105,00 & & 108,80 & - & 43,60 & - & 118,50 & - & - \\
\hline \multirow{2}{*}{1999} & ${ }^{(3)} 29.028$ & 27.753 & 95,50 & 29.045 & 100,00 & 27.602 & 95,30 & 27.565 & 94,90 & 28.652 & 98,70 & 24.071 & 82,90 & - & - \\
\hline & ${ }^{(4)} 27.279$ & - & 101,70 & - & 106,40 & - & 101,50 & - & 101,00 & - & 105,00 & - & 88,20 & - & - \\
\hline \multirow{2}{*}{2000} & ${ }^{(3)} 29.028$ & 27.616 & 95,10 & 29.988 & 103,30 & 27.825 & 96,80 & 28.005 & 96,40 & 27.579 & 95,00 & 26.713 & 94,60 & - & - \\
\hline & ${ }^{(4)} 27.865$ & & 99,10 & & 107,60 & & 95,80 & & 100,50 & & 98,90 & & 98,50 & - & - \\
\hline 2001 & 28.483 & 27.493 & 96,59 & 29.750 & 101,52 & 27.245 & 95,72 & 27.544 & 96,77 & 27.239 & 95,70 & 27.217 & 95,62 & - & - \\
\hline 2002 & 13.045 & 12.393 & 96,00 & 13.902 & 102,00 & 11.864 & 91,00 & 12.002 & 92,70 & 11.930 & 91,50 & 11.926 & 91,45 & - & - \\
\hline \multirow{2}{*}{2003} & $25.353 a$ & - & - & 25.176 & 98,59 & 24.077 & 94,29 & 23.830 & 93,28 & 23.789 & 93,10 & - & - & 24.140 & 97,12 \\
\hline & 25.504 & - & - & 25.176 & 94,99 & 24.077 & 90,84 & - & 89,87 & 23.789 & 93,10 & - & - & - & \\
\hline \multirow{2}{*}{2004} & $24.781 \mathrm{a}$ & - & - & 25.283 & 101,80 & 22.769 & 91,90 & 22.735 & 91,70 & 23.228 & 93,70 & - & - & 22.763 & 91,58 \\
\hline & 25.371 & - & - & - & 95,70 & - & 86,20 & - & 86,30 & - & 88,00 & - & - & - & \\
\hline \multirow{2}{*}{$\begin{array}{l}2005 \\
2006\end{array}$} & 24.164 & - & - & 25.482 & 106,45 & 23.961 & 99,24 & 23.581 & 99,24 & 23.931 & 94,04 & - & - & 23.951 & 93,98 \\
\hline & 24.552 & - & - & 25.463 & 103,71 & 24.137 & 98,31 & 24.424 & 99,48 & 24.338 & 99,11 & - & - & 24.506 & 99,81 \\
\hline
\end{tabular}

Fonte: IPPUC (2008)

Nota: A percentagem acima de $100 \%$ corresponde a crianças da RMC.

(1) As vacinas da Hepatite B e Hemophilus Influenza B começaram a ser aplicadas a partir de 1998.

(2) Em meados de 2002 foi implantada a vacina Tetravalente.

(3) População SINASC/SMS.

(4) População CEP/IPARDES. 
A vacina Tríplice Bacteriana e a vacina Sabin apresentaram oscilações na cobertura no período, em alguns anos observam-se índices próximos a $70 \%$, o que é considerado muito baixo pelos parâmetros estabelecidos pelos organismos nacionais e internacionais de saúde. Porém, destaca-se que, além de estarem presentes na rotina de vacinação nos serviços de saúde, estão também presentes em estratégias de campanhas vacinais, logo os índices de cobertura vacinal tendem a ter aumentos para se ter parâmetros que possibilitem a prevenção das doenças. E, por fim, se observa a entrada das vacinas contra Hepatite B e a vacina Tetra Valente, que ocorrem justamente após o aumento dos números de casos das doenças referidos anteriormente.

Quanto ao atendimento odontológico em Curitiba (Figura 4) no período de 1989 a 2002, houve aumento no número de procedimentos e atendimentos ao longo do período até 2001, no qual se registra uma significativa diminuição nos procedimentos com manutenção do número de atendimentos. Porém, no ano seguinte (2002) verifica-se o aumento de procedimentos retomando os parâmetros anteriores. Segundo a Secretaria Municipal de Saúde apud IPPUC (2008), os serviços públicos apresentam incremento significativo de procedimentos básicos no período de 2004 a 2006, e os prestadores de serviços apresentam queda na produtividade, fenômeno convergente com a implantação de equipes de odontologia nas Unidades Básicas de Saúde e nas Unidades Saúde da Família.

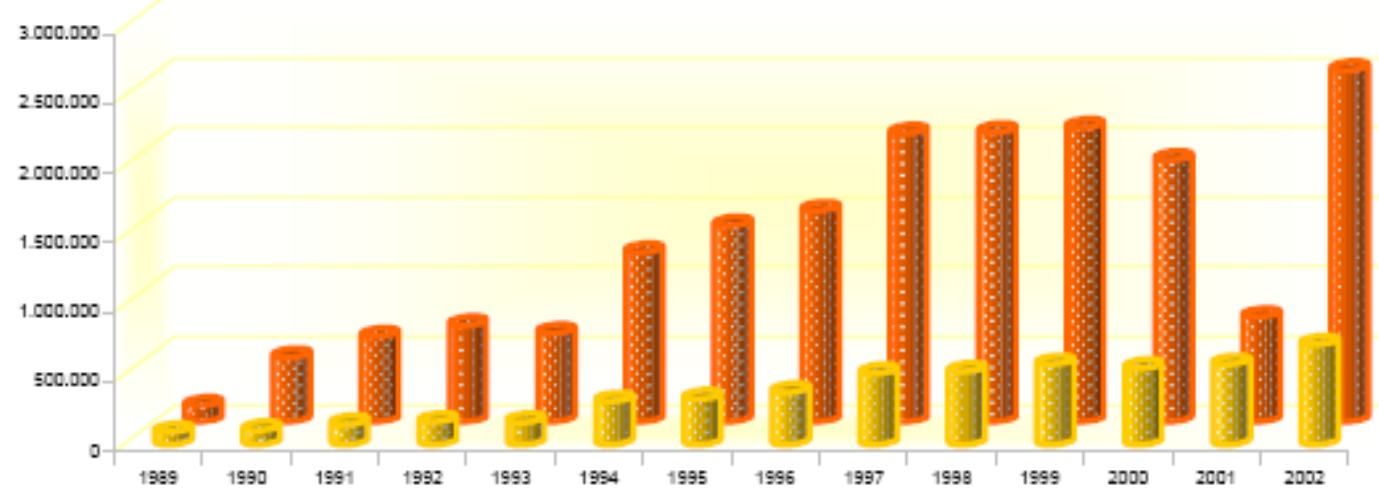

Figura 4 - Atendimentos e procedimentos odontológicos na rede municipal de saúde de Curitiba-PR, no período de 1992 a 2002, Curitiba-PR

Fonte: IPPUC (2008) 
O aumento de procedimentos também é registrado quando se analisa a produção de consultas médicas, mas nestes também se observam oscilações negativas como registradas no ano de 1997 (-19,78). Na série histórica representada a seguir (Figura 5) os percentuais de crescimentos foram altos em $1986(121,21)$ e, em 1992 (52,60). Porém, nos últimos anos, a partir de 2001, o crescimento se mantém e em 2006 houve elevação significativa no índice $(19,71)$. Ao relacionar esta produtividade com o aumento de serviços de saúde municipais compreende-se que o fenômeno é coerente com o aumento da cobertura destes serviços pela expansão da Estratégia Saúde da Família, estimulada pelo Ministério da Saúde junto aos municípios nos últimos anos por meio de incentivos financeiros.

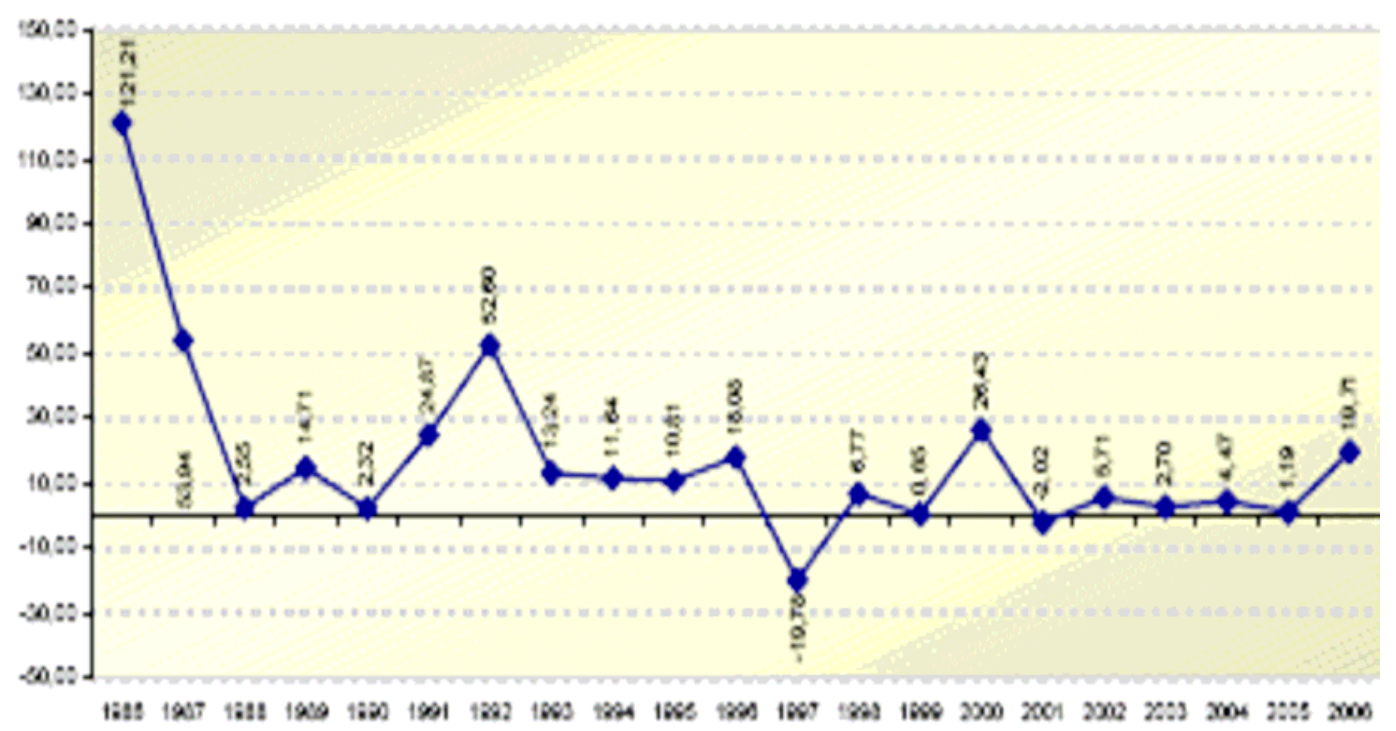

Figura 5 - Percentual de crescimento de consultas médicas na rede municipal de saúde de Curitiba, Fonte: IPPUC (2008)

Os registros sobre a produtividade da equipe de enfermagem não estão disponibilizados em bancos publicados para análises sobre atividades que são de responsabilidade da categoria. Isso ocorre apesar de haver diversas intervenções pelas quais a equipe é responsável nas rotinas dos serviços e, ainda, que estas tenham sido intensificadas nos últimos anos, conforme o estudo desenvolvido por Altino et al. (2006), ao descreverem as atividades da equipe de enfermagem do Bairro Novo em Curitiba-PR. As atividades identificadas no estudo foram relacionadas desde o gerenciamento do serviço 
até a execução de procedimentos junto ao usuário. A quantidade dessas ações foi significativa, e os registros estavam nos prontuários eletrônicos dos usuários como em outras bases de dados, mas não se encontram disponíveis em bancos de dados para possíveis análises.

\subsubsection{Os serviços de saúde em Curitiba}

A rede municipal de saúde de Curitiba é composta de serviços que desenvolvem ações de atenção básica à saúde, unidades de atendimento pré-hospitalar, unidades especializadas e unidades hospitalares. A seguir a Tabela 2 apresenta os equipamentos, segundo o tipo e quantidade.

Tabela 2 - Distribuição dos serviços de saúde do município, segundo tipo e quantidade de unidades - Curitiba - 2009

\begin{tabular}{l|r}
\hline \multicolumn{1}{c|}{ Tipo de serviço } & $\begin{array}{c}\text { Quantidade de } \\
\text { unidades }\end{array}$ \\
\hline Unidade de Saúde Básica & 50 \\
Unidade de Saúde ESF & 51 \\
Unidade ESF e Especializada & 01 \\
Centro de Urgências Médicas & 08 \\
Centro de especialidades & 03 \\
Especializada & 08 \\
Hospital municipal & 01 \\
Laboratório Municipal & 01 \\
Centro de Atendimento Psicossocial (CAPS) & 09 \\
Residência Terapêutica & 05 \\
\hline Total & $\mathbf{1 3 7}$ \\
\hline Fonte: IPPUC (2008) &
\end{tabular}

Conforme os dados acima, existem 121 (cento e vinte e um) Unidades de Saúde voltadas para a atenção básica nos 9 (nove) Distritos Sanitários do Município para atender a uma população estimada em 1.828 .092 pessoas para o ano de 2008 (IBGE, 2007). O IPPUC (2008) registrou que em 2006 havia 559.289 pessoas cadastradas no Sistema de informação da Atenção Básica (SIAB) e que o número de pessoas cadastradas em 2001 era de 220.904. Não houve registros sobre o número de equipes de saúde na atenção básica nos períodos. $O$ número de pessoas internadas segundo 0 Sistema de Informação Hospitalar do SUS (SIA/SUS), no município no ano de 
2006, foi de 99.675 no total, sendo que destas 14.274 foram por parto. No ano de 2001 os dados eram de 111.504 pessoas no total de internações e destas 17.059 foram por parto.

Os dados sobre a queda no número de internações são convergentes com a diminuição no número de leitos hospitalares de natureza pública, filantrópicos e privados, disponíveis no município pelo registro da Central Metropolitana de Leitos Hospitalares. Segundo IPPUC (2008), no período de 2004 a 2006, o número foi reduzido em 307 leitos cadastrados no total disponível. A maior redução foi de leitos ofertados por hospitais filantrópicos, 202 leitos, sendo que nestes em 2004 havia 1.815 e em 2006 foram diminuídos para 1.613 leitos. Seguindo a mesma lógica os hospitais privados reduziram 80 leitos no período. Em 2004 havia 519 leitos disponíveis e em 2006 a queda levou ao registro de 439 leitos privados no município. Os hospitais públicos registraram a menor redução, 25 leitos, sendo que em 2004 se tinha registro de 985 leitos e em 2006 o registro foi de 960 leitos hospitalares públicos disponíveis. A seguir estas informações distribuídas na Tabela 3.

Tabela 3 - Distribuição dos leitos cadastrados em Curitiba na Central Metropolitana de Leitos Hospitalares, públicos, filantrópicos e privados, disponíveis nos anos de 2004 e 2006 Curitiba-PR - 2009

\begin{tabular}{|c|c|c|c|c|}
\hline \multirow{2}{*}{ Tipo de Hospital } & \multicolumn{2}{|c|}{2004} & \multicolumn{2}{|c|}{2006} \\
\hline & $\mathbf{N}$ & $\%$ & $\mathbf{N}$ & $\%$ \\
\hline $\begin{array}{l}\text { Público } \\
\text { Filantrópico } \\
\text { Privado }\end{array}$ & $\begin{array}{r}985 \\
1.815 \\
519\end{array}$ & $\begin{array}{l}29,68 \\
54,69 \\
15,64\end{array}$ & $\begin{array}{r}960 \\
1.613 \\
439\end{array}$ & $\begin{array}{l}31,87 \\
53,55 \\
14,58\end{array}$ \\
\hline Total em Curitiba & 3.319 & 100.00 & 3.012 & 100,00 \\
\hline
\end{tabular}

Fonte: IPPUC (2008)

O número total de leitos em instituições hospitalares no município em 2004 foi de 6.304 e destes havia 3.319 disponíveis para a Central de Leitos, conforme demonstrado na Tabela 3. Ao se desdobrar a informação sobre quais eram as cinco instituições que ofertavam a maior quantidade de leitos para o SUS, encontra-se que a maior oferta era do Hospital de Clínicas da Universidade Federal do Paraná (HC-UFPR), com 539 leitos SUS. O segundo hospital com maior oferta, 474 leitos SUS, era o Hospital Psiquiátrico Nossa 
Senhora da Luz, seguido do Hospital Universitário Evangélico de Curitiba, com 441 leitos SUS, Hospital Pinel - Hélio Rotemberg, com 288 leitos SUS, e Hospital Universitário Cajuru, com 202 leitos SUS. Outros dados chamam a atenção no desdobramento das informações e entre estas se destaca que: $59,19 \%$ dos leitos hospitalares disponíveis no município eram cadastrados para o SUS; entre os hospitais de atenção especializada a psiquiatria e a obstetrícia eram as áreas que dispunham de maior número de leitos SUS; em algumas instituições especializadas o número de leitos SUS era zero, ou seja, se houvesse necessidade de internação nestas áreas, dispunham-se somente de leitos SUS nos Hospitais Gerais Públicos.

Baseado nos dados apresentados acredita-se que a ampliação da rede de serviços na atenção básica se deva às políticas de incentivos à Estratégia Saúde da Família do Ministério da Saúde. A diminuição de leitos SUS pode ter ocorrido por sua redução na psiquiatria, respeitando as diretrizes da política de desospitalização adotada pelo Ministério da Saúde. Nas outras especialidades a diminuição pode ter ocorrido pela dificuldade de se manter credenciamento de leitos para o SUS nos serviços privados, pois o financiamento para leitos hospitalar SUS está relacionado às dificuldades de regulamentação de verbas para o setor. Esta indefinição compromete o credenciamento de prestadores de serviços que têm crescente demanda de usuários de planos de saúde para atenderem.

$\mathrm{Na}$ busca de indicadores que referendassem parâmetros sobre o número de leitos hospitalares segundo a população, no Ministério da Saúde e em organismos internacionais de saúde, foi encontrado que esses parâmetros são variáveis de acordo com cada realidade, por isso não se pode afirmar que os números acima descritos são os desejados ou não (Rede Interagencial de Informações para a Saúde - RIPSA, 2008). Para que se tenha clareza sobre a adequação ou não do número de leitos hospitalares por habitante seria necessário o desenvolvimento de pesquisas específicas, mas como não é este o objeto do presente estudo indica-se a possibilidade de futuras investigações.

Para se obter as informações sobre RH-SUS foram pesquisados os bancos de dados dos diferentes sites já mencionados neste capítulo. Porém, ali não houve disponibilidade desta informação, portanto, foram considerados os 
seguintes dados coletados em entrevistas para a construção desta reflexão. Os números de profissionais lotados na Secretaria Municipal de Saúde no ano de $2008^{9}$ eram os seguintes: médicos 881 ; enfermeiros 459; cirurgiões dentistas 480; auxiliares de enfermagem (não há cargo de técnicos em enfermagem na SMS) 1680; auxiliar de consultório odontológico 488; técnicos de consultório odontológico 182; agente comunitário de saúde 1150, perfazendo o total de 4.170 profissionais descritos. Nos dados referidos não está descrita a quantidade de profissionais de outras categorias, tais como: psicólogos, nutricionistas, fisioterapeutas, médicos veterinários, farmacêuticos, biólogos que também estavam inseridas nos processos de trabalho da SMS naquele período. Neste caso, o total de profissionais no ano de 2008 era de 5.180 , segundo a SMS.

Tabela 4 - Profissionais lotados na Secretaria Municipal de Saúde de Curitiba, segundo categoria e quantidade - Curitiba- 2009

\begin{tabular}{l|r}
\hline \multicolumn{1}{c|}{ Profissional } & Quantidade \\
\hline Agente comunitário de saúde & 1150 \\
Auxiliar de consultório odontológico & 488 \\
Auxiliar de enfermagem & 1680 \\
Cirurgiões dentistas & 480 \\
Enfermeiros & 459 \\
Médicos & 881 \\
Técnicos de consultório odontológico 182 $^{(1)}$ & 182 \\
\hline Total $^{(1)}$ & $\mathbf{4 . 1 7 0}$ \\
\hline
\end{tabular}

Fonte: Dados de apresentações públicas das Coordenações de Enfermagem e do PACS

(1) O total apresentado não contempla todas as categorias profissionais existentes na SMSCTBA. Em outras informações se tem que o total de profissionais lotados em 2008 na SMS-CTBA era de 5.180. Neste caso, acredita-se estarem contempladas todas as categorias, porém, não havia discriminação da quantidade de cada uma delas.

\subsubsection{Organização administrativa de Curitiba e da Regional Boa Vista}

O município de Curitiba é dividido em 9 (nove) regionais administrativas Bairro Novo, Boa Vista, Boqueirão, Cajuru, CIC, Matriz, Pinheirinho, Portão e Santa Felicidade. Os distritos agregam números de bairros diferentes e também há registro de diferenças nas ocupações de seus territórios. Basicamente se tem que a ocupação do território do município foi a partir da região central

9 Os dados foram apresentados publicamente em eventos e confirmados em contatos pessoais com as Coordenações de Enfermagem e do PACS da SMS-CTBA. 
para as partes mais periféricas, sendo a região do Bairro Novo e Pinheirinho, parte sul do município, as áreas com urbanização mais recentes. A seguir Figura 6 apresenta a distribuição e identificação dos bairros, segundo regional administrativa.

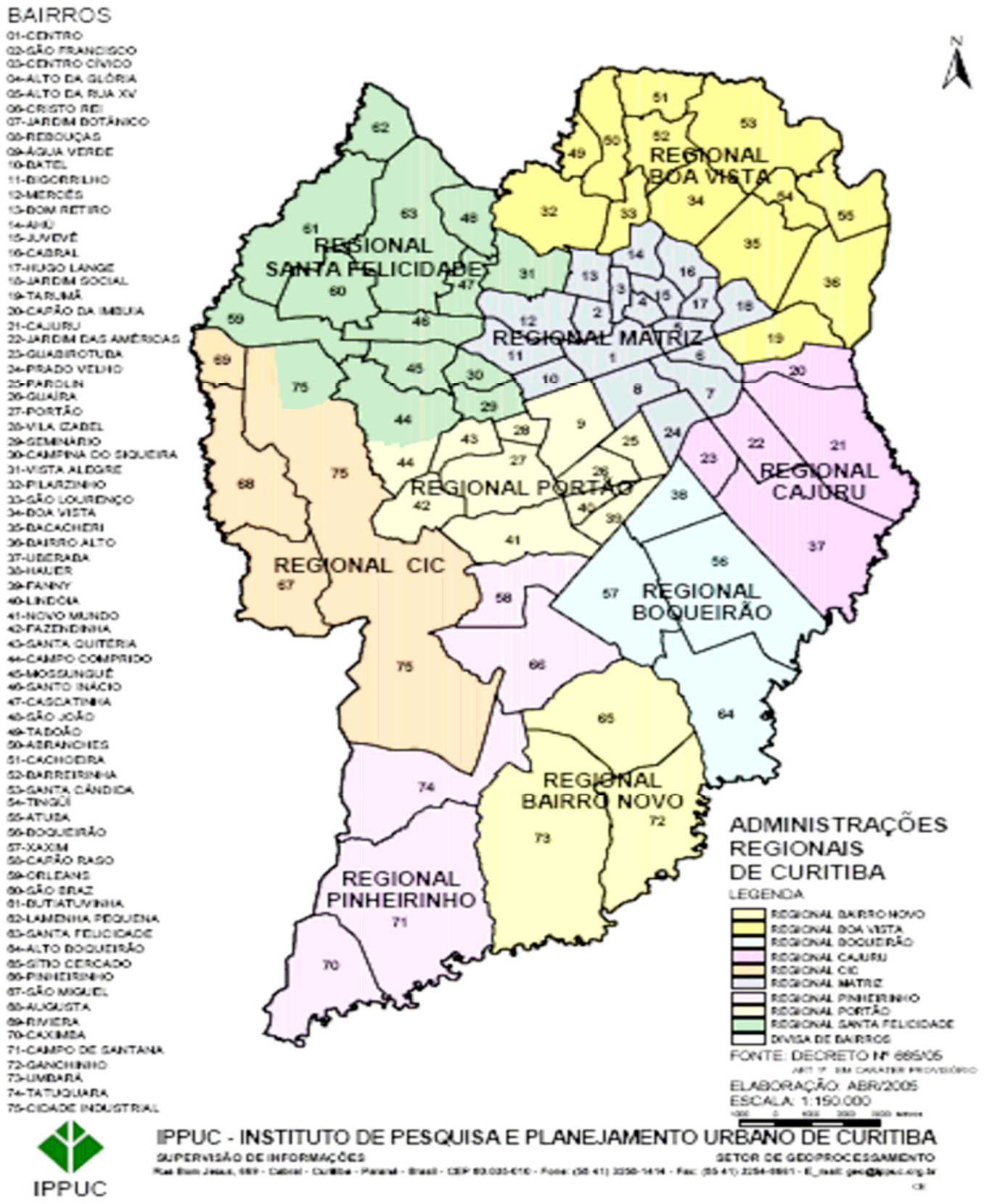

Figura 6 - Distribuição de bairros segundo regional administrativa no município de Curitiba-PR - 2008 Fonte: IPPUC (2008) 
A Regional Administrativa Boa Vista é composta por treze bairros: Tarumã, Pilarzinho, São Lourenço, Boa Vista, Bacacheri, Bairro Alto, Taboão, Abranches, Cachoeira, Barreirinha, Santa Cândida, Tingui, Atuba. Quanto aos dados populacionais nestes bairros, sete tiveram crescimento populacional acima da média da cidade no período de 1996 a 2000 (Pilarzinho, Taboão, Abranches, Cachoeira, Santa Cândida, Atuba e Bairro Alto) e dois, crescimento negativo (São Lourenço e Bacacheri). Os quatro bairros, restantes seguiram a tendência de crescimento populacional da cidade.

A seguir na Figura 7, representa-se a localização da Regional Administrativa Boa Vista do município de Curitiba, com destaque para o crescimento populacional no período de 1996 a 2000.

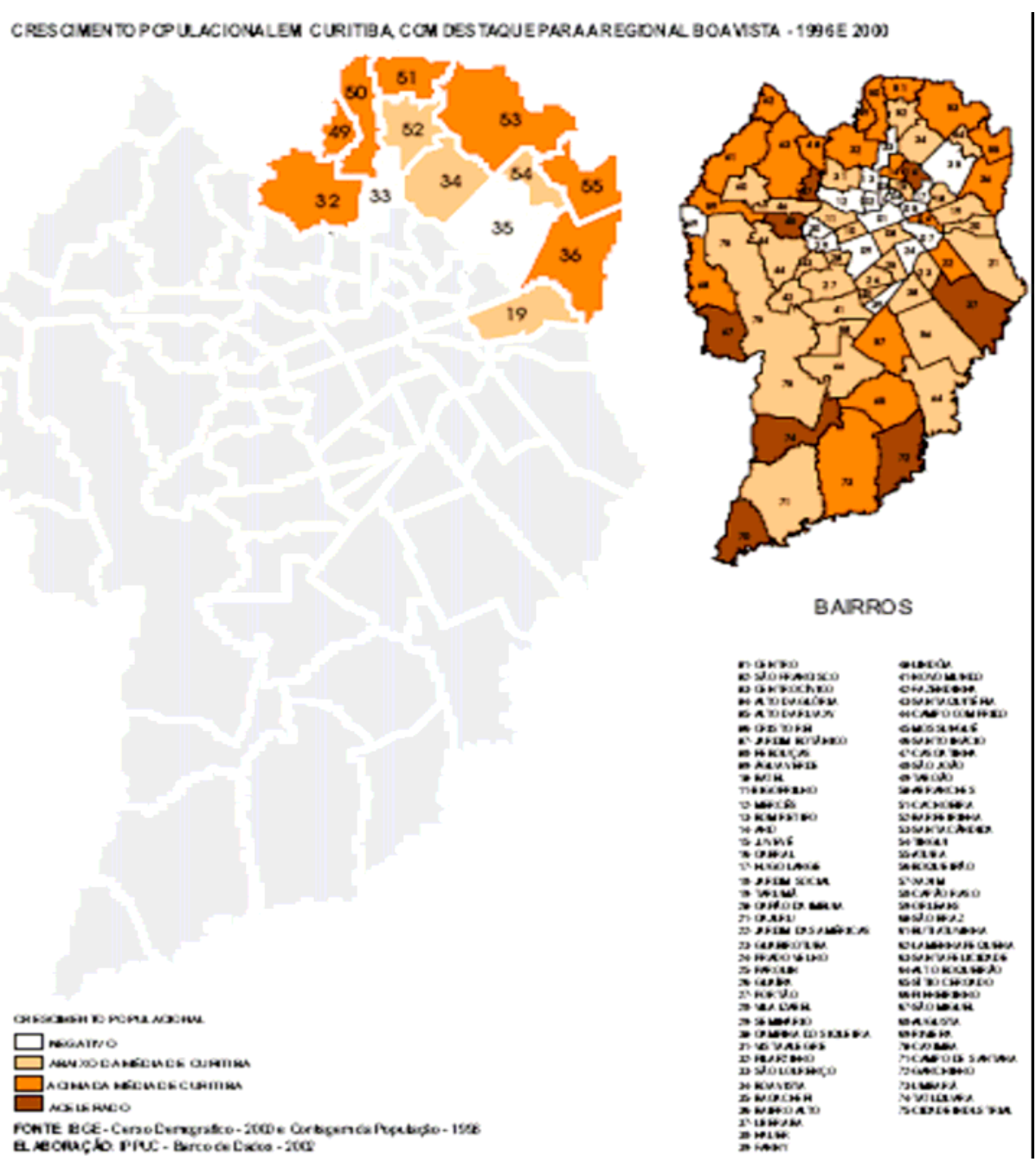

Figura 7- Regional Administrativa Boa Vista no município de Curitiba, segundo crescimento populacional no período de 1996 a 2000

Fonte: IPPUC (2005, p.13) 
O Distrito Boa Vista representa $14,40 \%$ do território do município de Curitiba. A população moradora desta Regional, segundo os dados do Censo IBGE 2000 , representava $14,22 \%$ da população da cidade, e em relação à distribuição populacional por faixa etária e sexo, nessa Regional havia significativo número indivíduos jovens (de 15 a 24 anos) e idosos (de 65 anos e mais) (IPPUC, 2005). Outra observação foi sobre a queda na natalidade no período, tanto no Município como na Regional Boa Vista. Nos dados referentes ao coeficiente de natalidade em Curitiba observa-se queda contínua na taxa, sendo registrados 21,0 nascidos vivos/1.000 hab. em 1995 e em 2007 13,4 nascidos vivos/1.000 hab. E a taxa de fecundidade no ano de 2007 foi de 1,44 filhos por mulher, sendo que valores abaixo de 2,1 filhos por mulher representam insuficiência na reposição populacional em determinado território (Curitiba, 2005, 2008a).

Os cinco bairros com maior densidade demográfica no Distrito Boa Vista, segundo o censo IBGE (2000), são: Bairro Alto (59,80 hab./ha), seguido do bairro Boa Vista (57,23 hab./ha), Tingüi (54,88 hab./ha), Barreirinha (45,60 hab./ha) e Pilarzinho (39,13 hab./ha). O bairro com a menor densidade demográfica é o Taboão (15,58 hab./ha) IPPUC, 2005).

$\mathrm{Na}$ estimativa populacional do IBGE para o ano 2006 tem-se a distribuição populacional segundo os bairros que compõem a Regional. $\mathrm{Na}$ tendência do crescimento populacional, o Bairro Alto apresenta-se ainda como o mais populoso (47.362) e o bairro menos populoso o Taboão (3.006) (IPPUC, 2005).

A política de apoio à infraestrutura para sedes de micro e pequenas empresas com o objetivo de gerar empregos e tirar empresas da informalidade definiu no município uma área denominada "linhão do emprego", como demonstra a Figura 9. Esta área liga vários bairros da cidade por uma grande avenida que teve a infraestrutura ampliada para receber instalações que atendessem à proposta a partir de 1997.

Na representação se observa que a Regional Boa Vista foi parcialmente contemplada, pois somente alguns de seus bairros ficaram próximos à área destinada à implantação de empresas e indústrias, o polo do Bairro Alto. Os bairros próximos são: Tarumã, Bairro Alto e Atuba. 
POPULAÇAOOO

REGIONLL BOA VISTA

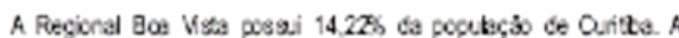
pidmice Earia da regional assemehase muto a da citade Ha grante

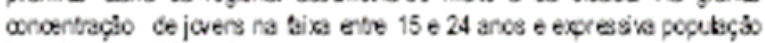
iscos (adia ce 65 ance).

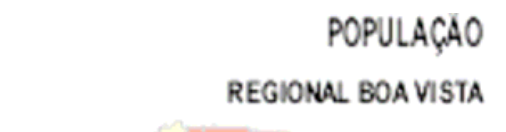

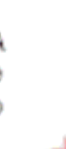

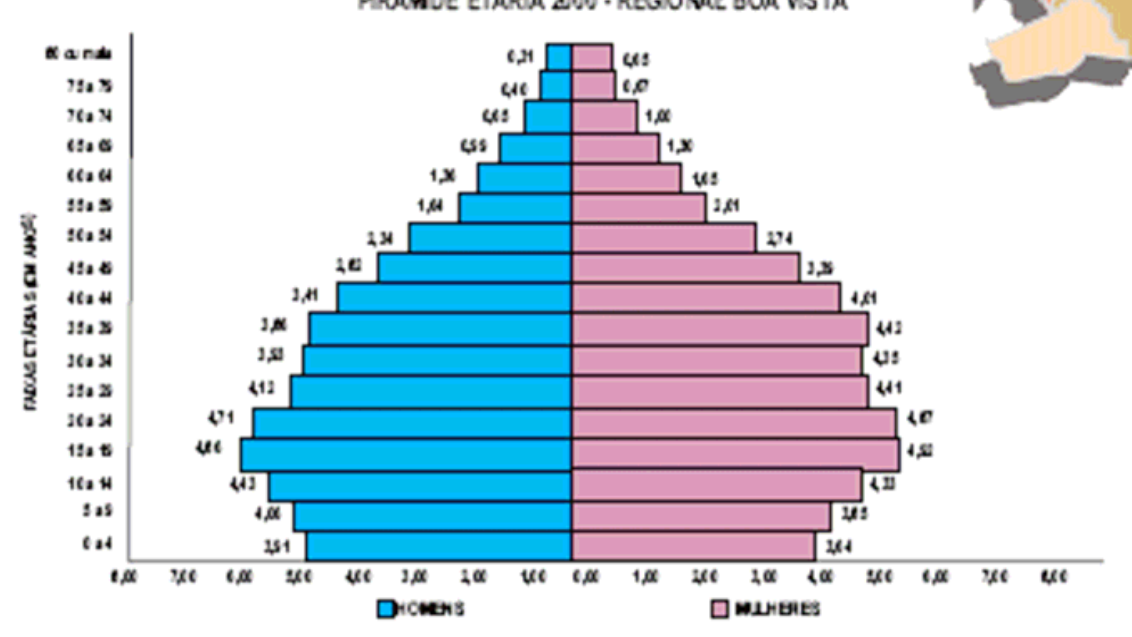

$$
\begin{array}{lr}
\text { Pepuacio } & 225.698 \\
\text { Antaina } & 6222.49 \\
\text { Densidabita } & 36.27
\end{array}
$$

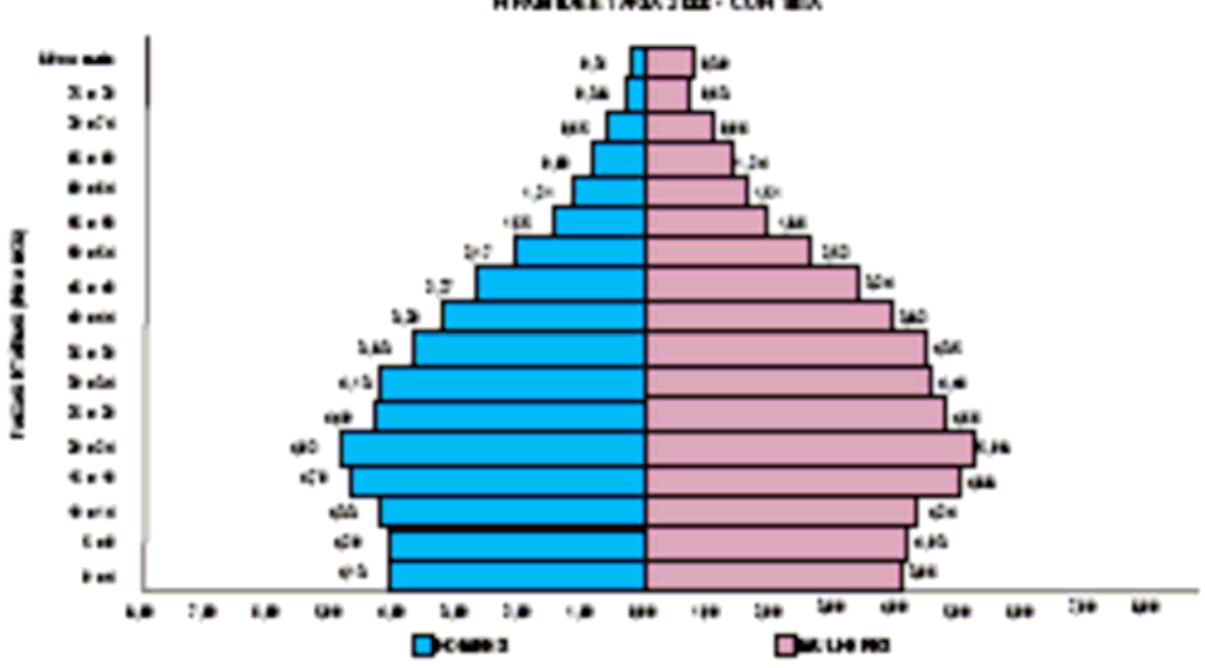

Figura 8 - Representação gráfica das pirâmides populacionais do município de Curitiba e Regional Boa Vista - Curitiba-PR - 2005

Fonte: IPPUC (2005, p.16) 


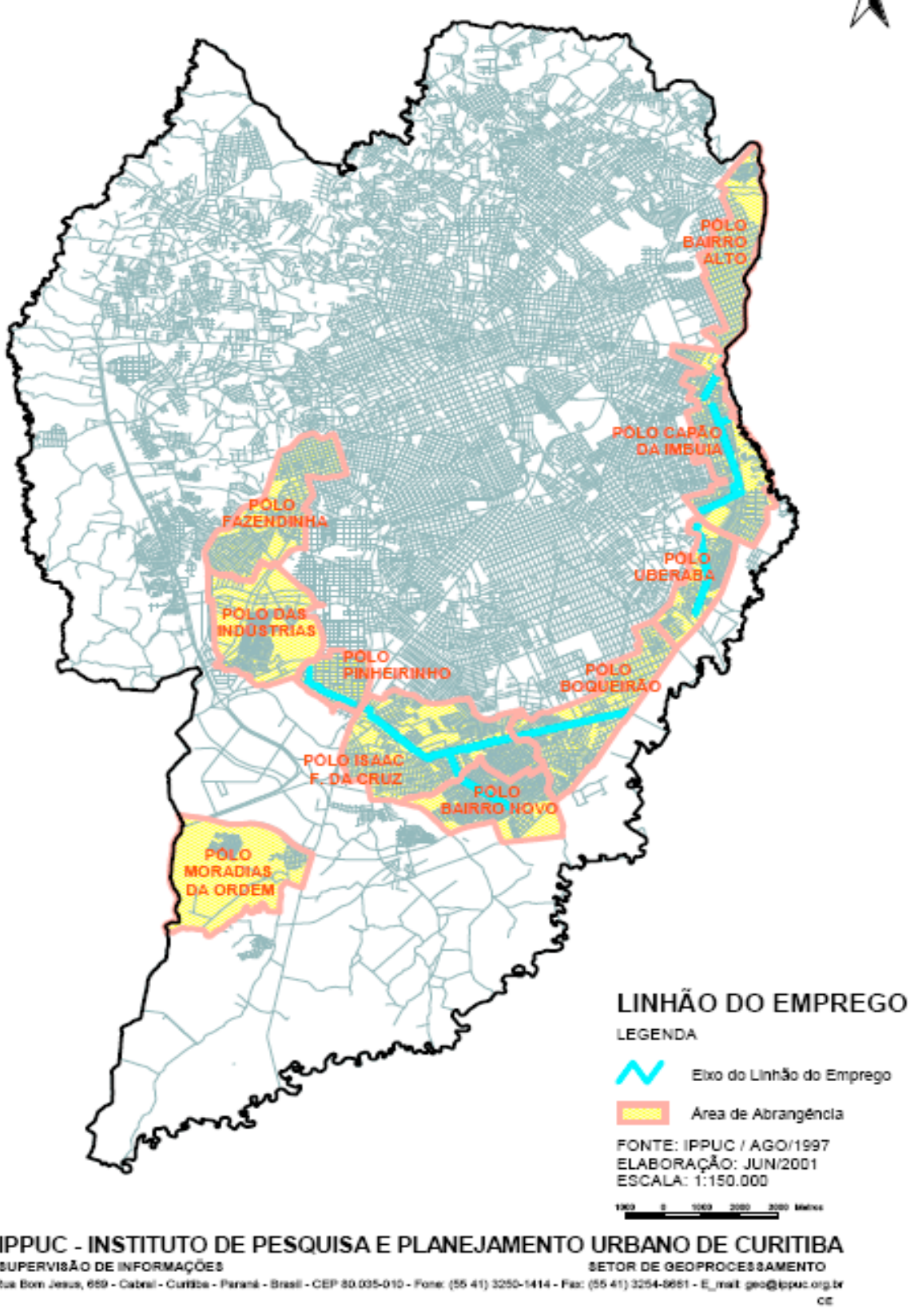

Figura 9 - Representação gráfica da área de abrangência do "Linhão do Emprego" no Município de Curitiba-PR - 2008

Fonte: IPPUC (2008) 
Quanto ao sistema de transporte coletivo o município conta com uma rede de serviços de integração com a região metropolitana, linhas com menor tempo de deslocamento entre as Regionais e ainda com linhas entre os bairros e o centro da cidade. Para a viabilidade da rede que integra as diferentes Regionais e os municípios da Região Metropolitana de Curitiba (RMC), existem espaços exclusivos nas ruas da cidade que formam um corredor para o deslocamento de ônibus com carrocerias articuladas que fazem estes trajetos. Outra opção para deslocamentos rápidos são as linhas de ônibus que têm poucas opções de paradas para os usuários, fazendo com que o trajeto seja percorrido em tempo menor, que são as linhas dos "ligeirinhos".

$\mathrm{Na}$ cidade não se conta com sistema de metrô e trens para transporte de passageiros, portanto todo o transporte coletivo é realizado exclusivamente por ônibus. Alguns dos ônibus têm mais de uma articulação de carroceria, podendo ter dois ou três módulos para que sejam transportados mais passageiros ao mesmo tempo. Atualmente o município está reformulando o sistema de transporte coletivo para garantir maior agilidade no deslocamento e também para aumentar a capacidade de transportar usuários. A reformulação conta com a ampliação e melhoria de pistas que são vias exclusivas para ônibus. A mudança, em fase de construção, se deve ao aumento significativo de usuários no sistema que já se mostra ineficaz em horários do dia com maior fluxo de pessoas.

Cabe destacar que o sistema coletivo de transporte é o principal meio de deslocamento para os trabalhadores que moram nos municípios da região Metropolitana e trabalham em Curitiba ou em outro município próximo. Alguns municípios são considerados "municípios dormitórios" devido à dinâmica social e econômica da região.

Quanto ao uso do solo em Curitiba, conforme IPPUC (2005), a Regional Boa Vista é basicamente residencial, sendo que no bairro Atuba se encontra uma concentração de área industrial. Outra observação é que nesta Regional as áreas de preservação ambiental estão localizadas no seu interior e são poucas (áreas verdes no mapa). Ver Figura 10, a seguir. 


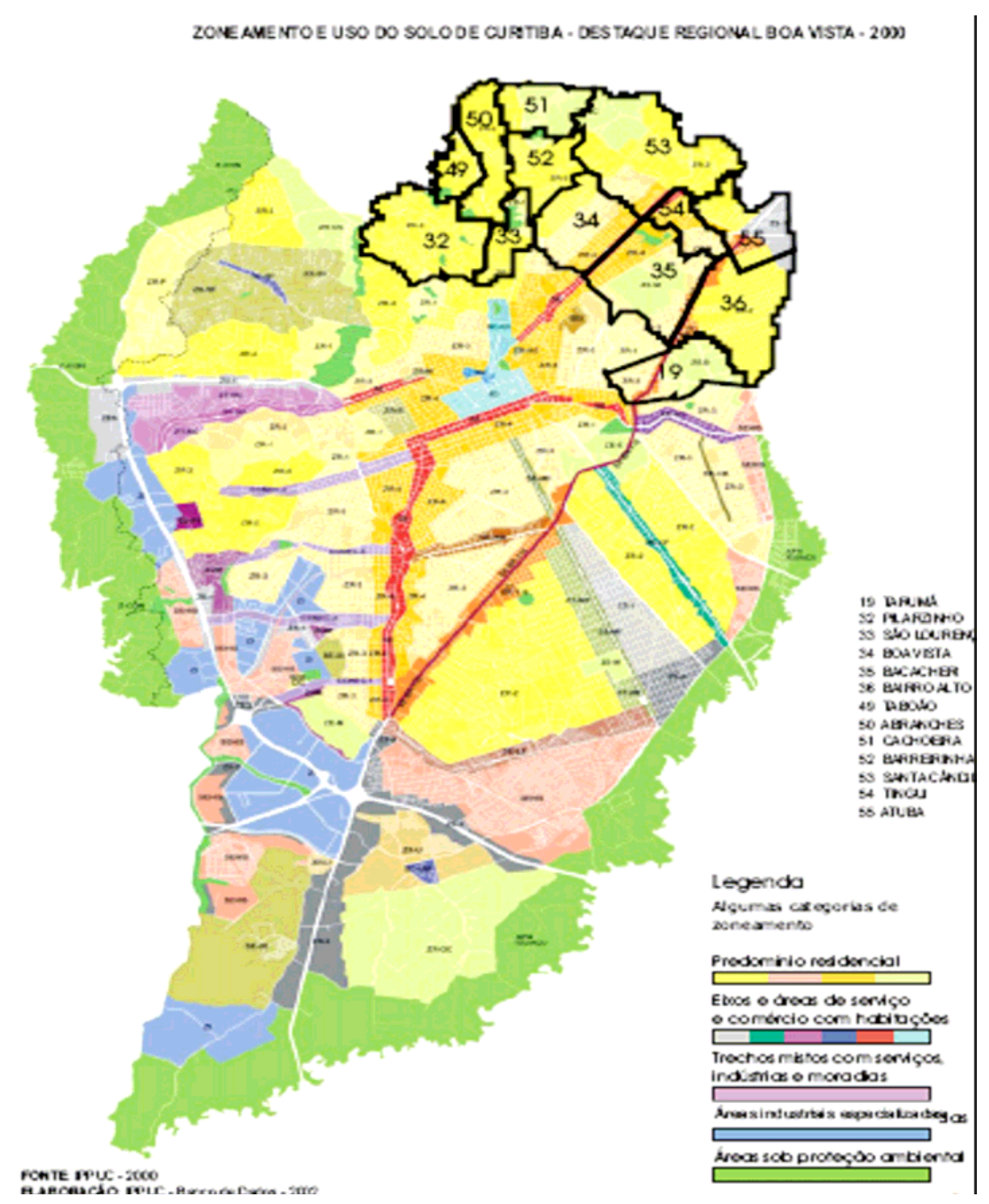

Figura 10 - Representação gráfica do uso do solo no município de Curitiba-PR com Fonte: IPPUC (2005, p.11)

Conforme dados do IBGE (2000) apud IPPUC (2005), a Regional Boa Vista tem $13,92 \%$ dos domicílios permanentes cadastrados no município (479.341 domicílios permanentes). Na Regional, o Bairro Alto é o território com maior número de domicílios permanentes cadastrados (12.126 domicílios permanentes), seguido do bairro Boa Vista (9.227) e Santa Cândida (8.041). Quanto ao cadastramento para a coleta de lixo, tem-se que a quase totalidade $(99,89 \%)$ dos domicílios permanentes são cadastrados para o recolhimento do lixo doméstico e que $99,71 \%$ possuem banheiros ou sanitários. Os dados da Regional são muito próximos dos dados do município, que tem 99,81\% dos 
domicílios permanentes cadastrados para o recolhimento do lixo doméstico e $96,61 \%$ que possuem banheiros ou sanitários.

Com relação ao tipo de domicílio particular permanente na Regional, observaram-se, nos dados do IBGE (2000), que $85,25 \%$ desses são casas, $14,57 \%$ apartamentos e $0,18 \%$ cômodo, sendo que Curitiba apresenta a seguinte distribuição: $74,92 \%$ de casas, $24,83 \%$ apartamentos e $0,24 \%$ cômodo. Portanto, observa-se que a região mantém moradias mais do tipo casa do que moradias do tipo apartamento, fato que demonstra um crescimento vertical menor do que outras regionais do município e ainda que há menos de moradias tipo cômodo. Quanto ao abastecimento de água nos domicílios da Regional, encontram-se as seguintes informações: $98,69 \%$ dos domicílios são abastecidos pelo abastecimento geral, neste caso pela companhia de água estadual (SANEPAR), 1,19\% faz uso de água de poço ou nascente e $0,11 \%$ utiliza outras fontes de água. Em Curitiba os dados mostraram que $98,61 \%$ dos domicílios recebem água do abastecimento geral (SANEPAR), $1,04 \%$ água de poço ou nascente e $0,35 \%$ utilizam água de outras fontes. Logo a situação do abastecimento e uso de água na Regional é mais favorável que a situação do município, principalmente na identificação de outras fontes, pois o índice de domicílios que fazem usos desse tipo de abastecimento na Regional é menor (IPPUC, 2005).

Os dados sobre ocupação irregular na Regional mostraram ruas não oficiais cadastradas, assentamentos sem regularização, assentamentos em regularização, loteamentos clandestinos sem regularização e loteamentos clandestinos em regularização, conforme identificado na Figura 11 a seguir. Ao observar o mapa se identifica que a concentração dos fenômenos apontados está nas partes mais periféricas da Regional, sendo que estas têm proximidade com os municípios da região metropolitana. Outra questão que se reflete sobre estas informações é que os registros oficiais muitas vezes ficam defasados com relação aos dados apontados. 


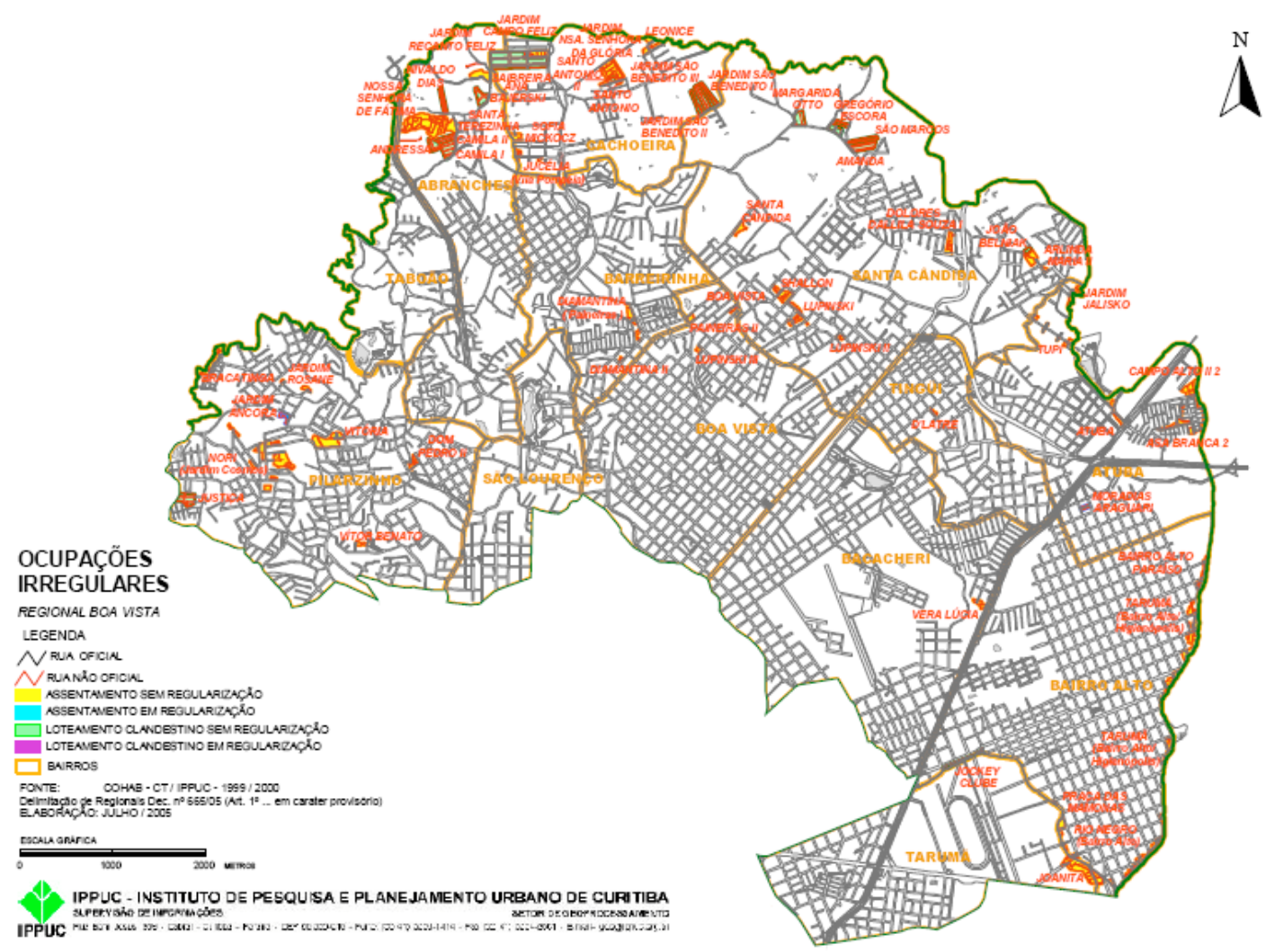

Figura 11 - Localização das áreas com ruas não oficiais, assentamentos sem regularização, assentamentos em regularização, loteamentos clandestinos sem regularização e loteamentos clandestinos em regularização na Regional Boa Vista - Curitiba-PR - 2005

Fonte: IPPUC (2005, p.72)

Nos dados relacionados à escolaridade da população acima de cinco anos, moradora da Regional Boa Vista, 5,03\% dela foi declarada como não alfabetizada. O restante, 94,97\%, foi declarado como alfabetizado. Estes dados são muito semelhantes aos do município, que apresenta 94,80\% de moradores alfabetizados e 5,20\% de moradores não alfabetizados. O bairro desta Regional que registrou o maior número absoluto de indivíduos não alfabetizados foi o Bairro Alto (2.216), seguido dos bairros Santa Cândida (1.598) e Pilarzinho (1.597). Nos índices de não alfabetizados responsáveis pelos domicílios da Regional Boa Vista identificou-se que o número de homens era menor $(22,41 \%)$ do que de mulheres $(27,50 \%)$. Essa tendência foi similar a situação dos responsáveis por domicílios no município, nos quais se teve que $24,80 \%$ eram homens não alfabetizados e $25,20 \%$ eram mulheres não alfabetizadas responsáveis por domicílios (IBGE, 2000). Os dados permitem refletir sobre os índices altos de analfabetos responsáveis por domicílios em 
centros urbanos. Com estas questões postas, acredita-se ser necessário pensar que, em uma sociedade do século XXI, o acesso à educação permitiria ao sujeito conquistar sua inserção na produção, assim como sua autonomia e emancipação.

\subsubsection{Aspectos populacionais e econômicos na Regional Boa Vista}

Com relação à análise dos dados do IBGE (2000), o IPPUC (2005) afirma que a população total da Regional Boa Vista era de 225.696 moradores. Considerada como População em Idade Ativa (PIA) 190.809 pessoas, $84,54 \%$ da população total da Regional. Dessa População em Idade Ativa foi registrado que 116.741 pessoas $(61,18 \%)$ compunham o percentual considerado como a População Economicamente Ativa (PEA) e somente 100.831 pessoas $(52,84 \%)$ do grupo População em Idade Ativa (PIA) compunham a População Ocupada (POC). Assim, os dados da Regional eram muito próximos aos dados do município, que apresentava a seguinte composição em sua população: 1.328.398 (83,69\%) moradores considerados na PIA; dessas 828.717 (62,38\%) eram pessoas que compunham a PEA e 712.040 (53,60\%) a POC.

Ao analisar a média de renda no município de Curitiba, segundo IPPUC (2005), observa-se a concentração da população de menor renda, abaixo de 3 salários mínimos, na região sul da cidade e a população com maior renda, acima de 6,01 a 20 salários mínimos, na região central. $\mathrm{Na}$ Regional Boa Vista o bairro Cachoeira apresentou população com renda média entre 3 a 5 salários mínimos, a menor registrada na Regional. No bairro Bacacheri identificou-se a população com renda entre 10,01 a 15 salários mínimos. Nos bairros do Tarumã e São Lourenço a população teve renda média de 15,01 a 20 salários mínimos, sendo que esta foi a maior renda média na Regional. Os demais bairros da Regional apresentaram grupos populacionais com renda média entre 5,01 a 10 salários mínimos.

Ao desdobrar a renda média da população com estudos que identificam a renda média do chefe do domicílio por setor censitário, conforme Figura 12 
a seguir, obteve-se evidência maior sobre a homogeneidade na região central da Regional e as diferenças mais significativas nos bairros mais periféricos. Neste caso, chama a atenção os grupos populacionais que foram identificados como abaixo de 3 salários mínimos nos bairros: Atuba, Pilarzinho, Cachoeira, Bairro Alto. Em poucos grupos a renda apareceu acima da média geral, ou seja, acima de 30 salários mínimos, isto ocorreu em quatro áreas da Regional.

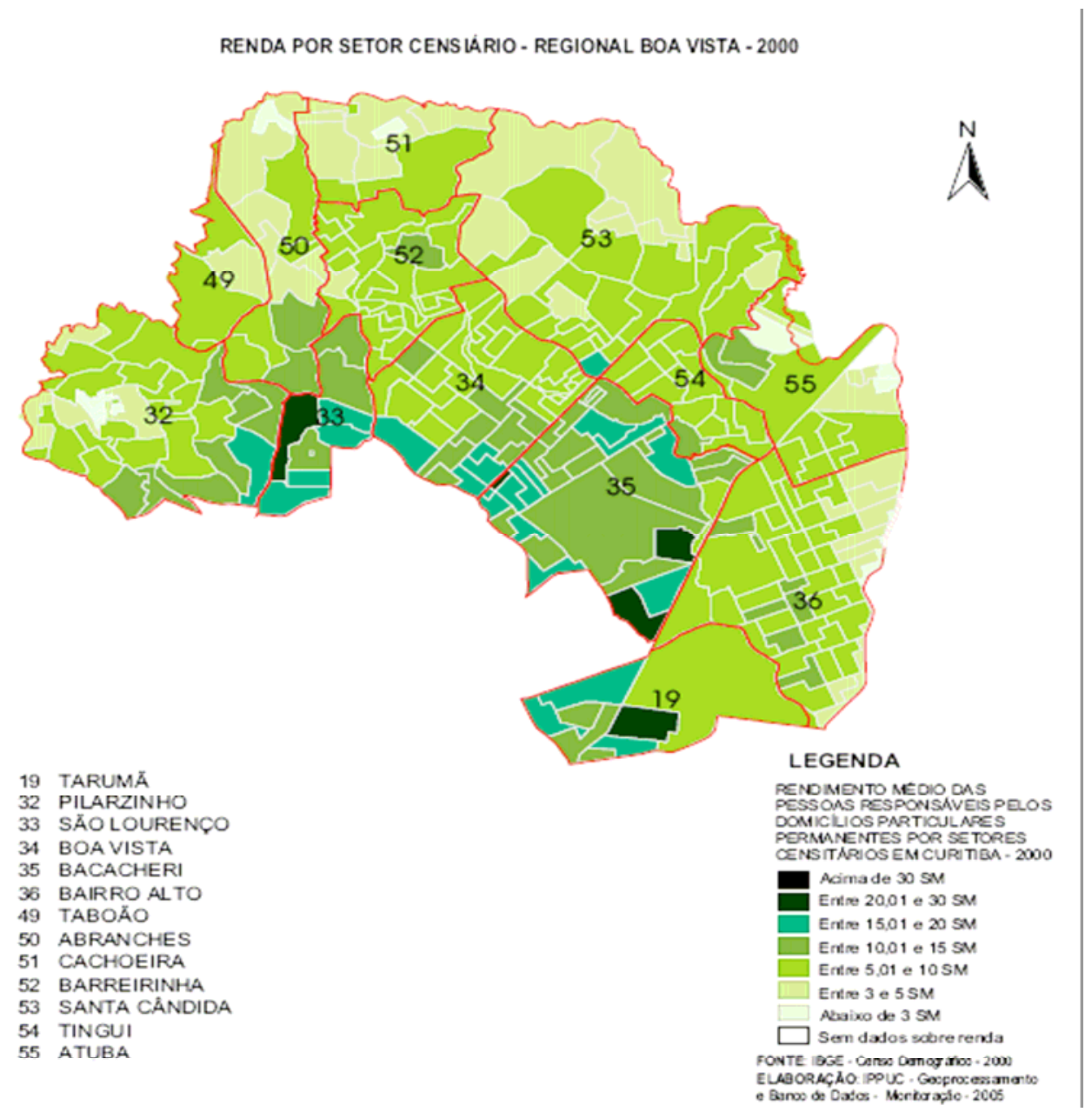

Figura 12 - Representação gráfica da renda média do chefe do domicílio, segundo setor censitário, na Regional Boa Vista no município de Curitiba-PR - 2005 Fonte: IPPUC (2005, p.48) 
Segundo o IPPUC (2005), a atividade econômica na Regional foi caracterizada, principalmente, por serviços e comércios. Existiam poucas indústrias fixadas neste território, logo a inserção da população no trabalho teve tendência às atividades predominantes. Este fenômeno mostrou-se coerente com os dados apresentados na caracterização das atividades econômicas do município, pois, segundo IBGE (2000) apud IPARDES (2008), as atividades relacionadas ao "comércio, reparação de veículos automotivos, objetos pessoais e domésticos" foram as que empregam o maior número de pessoas, seguida da "indústria de transformação" e "intermediações financeiras, atividades imobiliárias, aluguéis, serviços prestados a empresas".

\subsubsection{Equipamentos públicos na Regional Boa Vista}

Segundo o IPPUC (2005), os equipamentos do Setor Público da Saúde foram identificados e distribuídos no território da Regional Boa Vista conforme representação na Figura 13 abaixo, na qual se pode observar a existência dos seguintes serviços: uma unidade CEMUM - 24 horas, duas unidades básicas de saúde, dez unidades básicas e clínica odontológica, três unidades PSF e clínica odontológica e uma unidade Saza Lattes, totalizando 17 serviços de saúde e ainda a sede do Distrito Sanitário que comporta o serviço de vigilância epidemiológica, serviço saúde ambiental com equipe de vigilância sanitária e equipe de saúde mental.

O registro do Instituto referido acima ainda não tem as mudanças recentes do sistema de saúde da Regional. Assim, registra-se que em 2008 ocorreram mudanças na Unidade de Saúde 24 horas Boa Vista, que se encontra em fase de re-estruturação predial para atender às modificações nas intervenções em saúde desenvolvidas por seus profissionais na assistência às urgências e emergências como em todas as unidades de saúde 24 horas do município. Esta unidade passou a ser denominada CEMUM (Centro Municipal de Urgências Médicas) Boa Vista e vai ocupar um amplo prédio com promessa de ampliação de equipe para garantir acesso à maior demanda. Outra mudança 
na Regional foi na unidade Saza Lattes, que passou a ser denominada Unidade de Saúde Medianeira e atende como unidade básica de saúde. Houve redefinição de áreas de abrangências entre as unidades dos territórios vizinhos e ampliação da área de abrangência da Regional pela implantação da nova unidade. A ampliação foi para a incorporação de parte do território da Regional Matriz para a Regional Boa Vista. Logo, houve aumento da população-alvo para a Regional. Porém, este é um processo ainda em discussão para oficialização posterior.

Os resultados de uma pesquisa sobre o desempenho do setor saúde na Regional em 2000, segundo IPPUC (2005), indicaram a seguinte avaliação da população: ruim para a população do bairro Cachoeira; regular para os moradores do Abranches, Barreirinha, Santa Cândida Boa Vista e São Lourenço; bom para os moradores do Tingüi, Atuba, Bairro Alto e Tarumã; ótimo pelas populações dos bairros do Taboão e do Bacacheri.

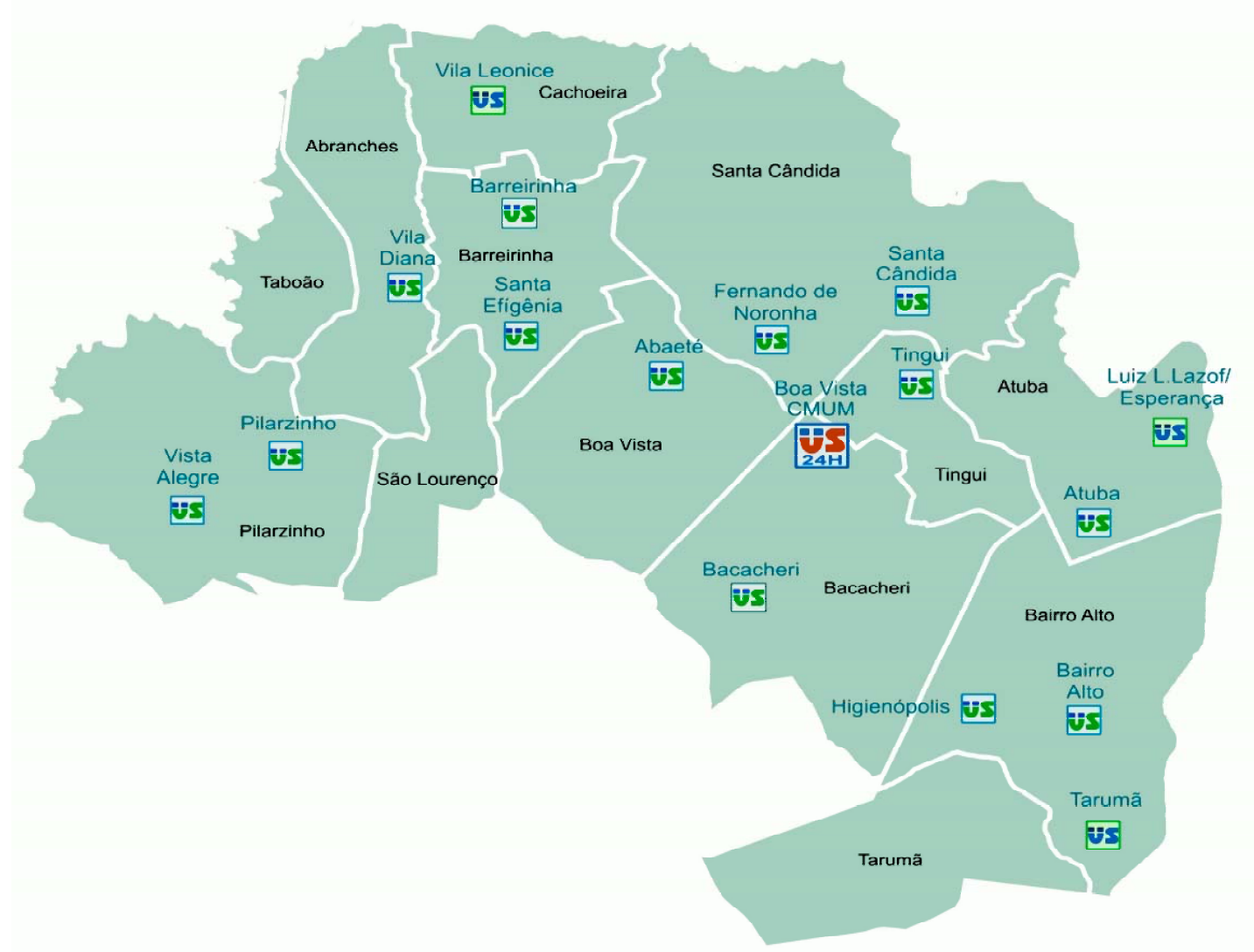

Figura 13 - Distribuição dos equipamentos de saúde na Regional Boa Vista - Curitiba-PR - 2008 Fonte: IPPUC (2008) 
$\mathrm{Na}$ identificação de Equipamentos Públicos do Setor de Educação na Regional teve-se registro de biblioteca, farol do saber, Centro Municipal de Educação Infantil (CEMEI), centro de educação infantil conveniado, escola municipal, CMAE, escola estadual, Programa de Integração da Infância e Adolescência (PIA), Espaços de Contraturno Socioambiental (ECOS-PIA), faculdades e campus.

Com relação aos Equipamentos Comunitários de Abastecimento, foram identificados no território da Regional Boa Vista: armazém da família, câmbio verde, mercado popular, feira livre, feira do pescado, feira noturna, feira gastronômica, sacolão curitibano volante, varejão, direto da roça, lavoura projeto, cuja distribuição está representada na Figura 14 a seguir.

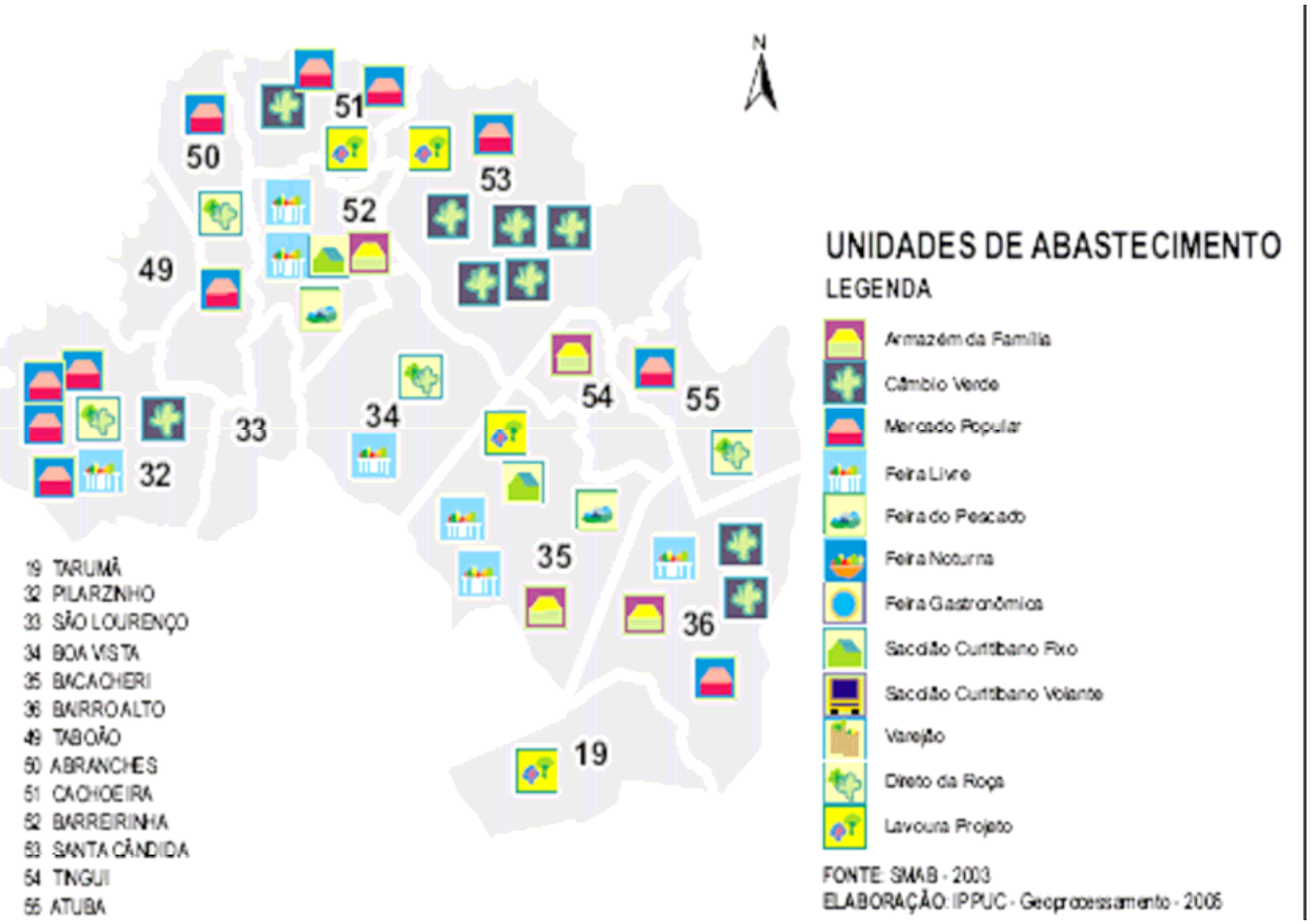

Figura 14 - Distribuição dos equipamentos comunitários de abastecimento na Regional Boa Vista Curitiba- PR - 2005

Fonte: IPPUC (2005, p.42) 


\subsection{AS CONFERÊNCIAS MUNICIPAIS DE SAÚDE - DEZ ANOS DE PARTICIPAÇÃO DO MOVIMENTO SOCIAL ORGANIZADO NA ELABORAÇÃO DE INTERVENÇÕES EM SAÚDE}

As Conferências de saúde, em todas as esferas de governo, têm sido espaços para a participação de segmentos da sociedade no processo de elaboração e aprovação de Políticas Públicas no setor. A regulamentação do processo participativo foi a partir da promulgação da Constituição Federal de 1988, da Lei Orgânica da Saúde n. ${ }^{\circ} 8.080 / 90$ e, posteriormente, pela Lei n. ${ }^{\circ} 8142 / 90$. Entre os participantes do processo ao longo dos últimos vinte anos de implantação do SUS encontram-se representantes do movimento social organizado, gestores do setor, trabalhadores de saúde, políticos e prestadores de serviços ao Sistema Único de Saúde.

Com base nas propostas aprovadas nas Conferências de Saúde, as intervenções do setor devem atender às necessidades em saúde expressas pelos indivíduos, comunidades ou populações. Nesse sentido, o município de Curitiba tem promovido suas Conferências desde o início da década de 1990, com periodicidade regular, ou seja, a cada dois anos.

Com o objetivo de compreender o discurso que definiu as intervenções em saúde desenvolvidas pelo setor, logo da prática do enfermeiro na Atenção Básica, foram analisados os relatórios das 6 (seis) Conferências Municipais ocorridas nos últimos dez anos (1997, 1999, 2001, 2003, 2005 e 2007). Neles se identificou os temas abordados nas propostas aprovadas, a forma de organização do evento e o número de participantes na plenária final.

Após um longo processo de análise dos materiais, cabe registrar, inicialmente, que os relatórios apontaram avanço tanto na organização e realização das Conferências como nos registros de dados. Logo, houve uma diferença significativa nos registros analisados, pois, em cada uma das Conferências, o relatório final seguiu um modelo próprio e, no último documento analisado, relatório da $9 .{ }^{a}$ Conferência, houve preocupação com registros detalhados sobre os eventos antecedentes à Conferência, participações e sistematização das propostas aprovadas na plenária. Com o objetivo de 
compreender as mudanças ocorridas nas propostas, segundo os temas abordados por elas, foi organizado um roteiro para agrupar as intervenções aprovadas por temática às quais estas se relacionavam. Este processo foi realizado em cada um dos relatórios. O roteiro elaborado foi baseado nos temas emergentes nos relatórios.

Portanto, as intervenções aprovadas em cada uma das Conferências foram agrupadas segundo as temáticas: promoção da saúde; atenção básica; atenção pré-hospitalar; atenção de média e alta complexidade; assistência farmacêutica, segurança alimentar e nutricional; saúde bucal; saúde mental; diabetes; hipertensão arterial; cânceres e neoplasias; patologias agudas e doenças transmissíveis; violências e causas externas; HIVIAIDS; hanseníase; tuberculose; saúde do idoso, saúde da mulher, saúde da criança; saúde do adolescente; saúde do trabalhador e portador de deficiência.

Nessa sistematização procurou-se ainda identificar temas transversais nas intervenções aprovadas nas Conferências, os quais foram: financiamento do setor, organização dos serviços, modelo de intervenção em saúde, intersetorialidade, qualificação dos profissionais, participação popular e formação de conselheiros de saúde.

A seguir são apresentados os resultados da análise.

\subsubsection{Aspectos relevantes nos temas das propostas aprovadas}

As propostas de intervenções aprovadas foram diversas em todas as Conferências de Saúde, e nestas se reconhece o caráter coletivo e individual para a promoção da saúde, prevenção e cura de adoecimentos. As intervenções de caráter preventivo foram relacionadas aos cuidados com o meio ambiente $\mathrm{e}$ às intervenções para indivíduos e grupos em risco de desenvolver o agravo. Os objetivos eram de atender às necessidades em saúde dos usuários pela especificidade do momento do ciclo de vida ou para atender às necessidades em saúde de usuário ou grupo portador de adoecimento e diminuir o impacto das relações de produção e reprodução social sobre o meio ambiente. 
Nessa lógica houve muita repetição das intervenções aprovadas, pois a mesma proposta era aprovada para atender a um determinado grupo pelas características do ciclo de vida e posteriormente era aprovada proposta muito semelhante para atender ao indivíduo ou ao grupo portador de um agravo. A repetição também se dava quando se aprovavam propostas de intervenção a serem desenvolvidas em um determinado serviço. Quanto aos cuidados com o meio ambiente houve propostas em todas as Conferências para que o setor saúde atuasse em parceria com outros setores no sentido de conscientizar os cidadãos sobre a importância de preservação do meio ambiente para a qualidade de vida.

Como exemplo da repetição, referida acima, têm-se propostas que relacionaram prioridade para o grupo de usuários idosos no desenvolvimento das intervenções aprovadas para o enfrentamento da Hipertensão Arterial. Registravam-se propostas aprovadas para enfrentamento ao agravo e no mesmo evento foram registradas propostas de intervenções aprovadas para serem desenvolvidas junto ao grupo de idosos portadores de Hipertensão Arterial, adoecimento considerado de alta prevalência no grupo etário.

A questão referida acima remete à discussão sobre qual seria a sistematização mais adequada para a elaboração e aprovação das propostas de intervenção pela lógica de eventos, tal como as Conferências de saúde, que pressupõem participação com amplas discussões sobre o processo saúdedoença da população para subsidiar Políticas Públicas e organização dos serviços do setor. Portanto, as propostas de intervenção deveriam ser elaboradas para atender às necessidades em saúde dos usuários segundo o ciclo de vida ou segundo os adoecimentos identificados pelos índices epidemiológicos, no sentido de promover a saúde, prevenir adoecimentos e recuperar a capacidade do indivíduo para a vida.

$\mathrm{Na}$ análise dos relatórios essa dificuldade para estabelecer o eixo de discussão foi percebida nos registros de todas as Conferências, sendo que nas duas últimas (oitava e nona) houve avanço na sistematização, mas ainda ocorreram repetições de propostas aprovadas pela indefinição descrita. Nos discursos e relatório final, fica evidente que para modificar os índices epidemiológicos e organizar as intervenções aprovadas se seguiu a lógica da 
programação em saúde com indicação de elaboração, implantação e atualização de protocolos em saúde. Isso pode ser percebido mais significativamente a partir da 6 . $^{\text {a }}$ Conferência. Desde esse evento foram aprovadas propostas que indicavam protocolos novos e aprofundamento de outros. As propostas passaram a ser elaboradas em encontros específicos com especificidades de temas (saúde mental, saúde do trabalhador, saúde bucal) antecedentes às conferências, tal processo foi mais acentuado na oitava e nona Conferências.

Nos dez anos de Conferência as propostas aprovadas buscaram a articulação entre diferentes atividades para dar conta de agravos identificados pelos índices epidemiológicos e sanitários. Nesse sentido, a preocupação foi predominantemente no enfrentamento às questões apontadas, e a maioria das propostas aprovadas indicou intervenções que eram baseadas no modelo curativista individual. A influência do modelo referido pode ser identificada mesmo em propostas de intervenções que eram para ser desenvolvidas nos serviços da atenção básica. Dessa maneira, o enfrentamento ao agravo ou a prevenção do desenvolvimento de novos casos deste teve centralidade em grupos e indivíduos de risco como prioritários para receber a assistência e, ao mesmo tempo, ou seja, na mesma Conferência, foram aprovadas propostas que indicaram a responsabilidade do indivíduo e da família pela adoção de estilo de vida mais saudável e desenvolvimento do autocuidado como medidas para a promoção da saúde e para o enfrentamento ao agravo. Outro enfoque identificado nas propostas está relacionado à co-responsabilização do profissional inserido em equipe local de saúde sobre o processo de promoção à saúde, prevenção do adoecimento e adesão ao tratamento que o usuário deveria desenvolver.

Esta análise permite afirmar que as propostas de intervenção direcionam a responsabilidade do processo saúde-doença para o indivíduo e co-responsabilizam o profissional do serviço local de saúde para o enfrentamento do mesmo; mas nos dez anos de Conferência também se discutiu que havia necessidade de se garantir financiamento para o setor, acesso nos serviços para os usuários, reversão do modelo de assistência, entre outras questões que impossibilitavam o desenvolvimento de intervenções em saúde. Logo, a precariedade do sistema denunciada em algumas propostas já indicava que 
os sujeitos não poderiam ser responsabilizados unicamente por seus processos saúde-doença.

Intervenções de caráter coletivo ou indireto para promover a vida com qualidade ou prevenir agravos também foram identificadas nos discursos, sendo que tais intervenções estiveram mais acentuadas em propostas aprovadas nas três últimas conferências, sétima, oitava e nona. Porém, nessas mesmas Conferências se reafirmou que eram necessárias mudanças de comportamentos, ou estilo de vida adotado pelos indivíduos em propostas relacionadas à promoção à saúde. Nesse sentido, o enfoque norteador novamente foi para se responsabilizar os sujeitos por suas escolhas de hábitos para uma vida com mais qualidade com a família e na comunidade.

Cabe ressaltar que na $4 .^{a}$ Conferência houve grande número de propostas de intervenções de caráter coletivo, porém os registros mostram dificuldade na compreensão do que era atribuição do setor e quais seriam intervenções que poderiam depender de articulação para serem realizadas. Esta afirmação se deve à ênfase em recomendar busca de parcerias para o desenvolvimento das intervenções aprovadas na Conferência, permitindo refletir sobre qual era a lógica das propostas registradas - a busca de parceria para promover as intervenções em saúde. Isso pode ter ocorrido pela dificuldade de recursos que se tinha no setor ou pela precariedade na definição das atribuições e responsabilidade do próprio setor para intervir no processo saúde-doença vivido pelos cidadãos.

Para a atenção básica à saúde as propostas indicaram a necessidade de reversão do modelo de assistência desenvolvido. A adoção do Programa de Agentes Comunitários em Saúde (PACS) e da Estratégia da Saúde da Família (ESF) foi aprovada para se garantir aumento de cobertura e acesso para os usuários. As propostas indicaram ainda a necessidade de mudanças nas condições de trabalho dos serviços locais aprovando a inserção de mais profissionais no processo de trabalho local com a participação popular na definição de intervenções em saúde.

Para atuar em determinadas situações de saúde, a partir da 7. ${ }^{\text {a }}$ Conferência foram aprovadas as Redes de Proteção, nas quais os serviços locais seriam representados. Contraditoriamente algumas propostas, registradas 
no mesmo evento, retrocederam nos avanços apontados. Entre esses indicativos de retrocesso destaca-se que a maioria das intervenções tinha enfoque curativista para portadores de doenças ou grupos de risco para determinado adoecimento e, ainda, que em algumas intervenções houve a indicação dos representantes dos movimentos sociais organizados para atuar juntamente às suas comunidades, no caso transferindo a responsabilidade do poder público quando havia insuficiência de recursos ou ineficácia das ações desenvolvidas pelos profissionais.

Para a atenção pré-hospitalar as propostas indicaram a implantação do Serviço Integrado de Atendimento ao Trauma e Emergência (SIATE) e Serviço de Atendimento Médico de Urgência (SAMU) a partir da 6. ${ }^{\text {a }}$ Conferência para auxiliar no atendimento de urgências pré-hospitalares que era desenvolvido nas Unidades 24 horas e já apresentava capacidade esgotada. Posteriormente, aprovaram-se propostas que indicaram as parcerias com Instituições de Ensino Superior, públicas e privadas, para garantir ampliação dos serviços e na 9. ${ }^{\text {a }}$ Conferência foi apresentada a proposta dos Centros Municipais de Urgências Médicas (CMUM) que estão sendo implantados para substituir as Unidades 24 horas. Apesar da aprovação das parcerias referidas, houve também aprovação de propostas que apontaram a necessidade de contratação de novas equipes para os serviços por meio de concursos públicos.

A garantia de acesso para o usuário foi outro enfoque dado em diversas propostas que indicaram: ampliação e descentralização de serviços e recursos; aumento de cobertura de determinados programas ou estratégia; implantação de intervenções, ações e serviços para enfrentar o adoecimento ou para atender necessidades em saúde específicas de um segmento populacional. Neste caso, discutia-se também a importância do acesso aos diagnósticos precoces, assim como a adesão dos usuários aos tratamentos prescritos para doenças transmissíveis ou crônicas por meio de informações que também lhes permitissem desenvolver o autocuidado.

Em relação ao acesso aos serviços de média e alta complexidade para a atenção à saúde foram apontadas ampliações e implantações de intervenções deste nível da assistência à saúde como necessárias em todas as Conferências. Em algumas foram encontradas propostas de implantação de 
assistência de maior complexidade tecnológica e, em outras, se recomendou a contratação de prestadores de serviços que garantissem o acesso a determinada intervenção em saúde. Portanto, percebe-se que a dificuldade de acesso foi contínua neste nível da atenção à saúde nos dez anos das Conferências.

Propostas relacionadas às intervenções desenvolvidas pelos serviços de Vigilância Sanitária e Vigilância Epidemiológica também estiveram presentes em todas as Conferências, pois a utilização dos índices sanitários, epidemiológicos e populacionais permitiu e justificou a elaboração de propostas que foram aprovadas para reverter situações de saúde indesejáveis. Na análise dos relatórios se percebe que as intervenções destes serviços foram estruturadas e ampliadas ao longo do período estudado, pois inicialmente houve registro para a aprovação do Código Sanitário Municipal para posteriormente se ter expansão de atribuições com implantação de novas intervenções que ficaram sob a responsabilidade destes serviços. Esse processo foi possível com a ampliação no número de profissionais e inserção de novas categorias nos processos de trabalho dos serviços nos Distritos Sanitários com o objetivo de atingir as metas que eram pactuadas, conforme se pode identificar em propostas aprovadas. Cabe ressaltar que as metas, além de objetivar as mudanças nos índices sanitários, foram também para que o sistema municipal de saúde atendesse aos compromissos estabelecidos com a Secretaria Estadual de Saúde e o Ministério da Saúde.

Nas intervenções para portadores de doenças crônico-degenerativas e para portadores de doenças infecto-contagiosas foram identificadas tanto ações de caráter individual curativista como ações de caráter coletivo para a promoção da saúde e a prevenção dos adoecimentos, sendo que predominantemente foram encontradas aquelas com centralidade no tratamento de usuários já portadores de adoecimento com a justificativa de que havia necessidade de se reverter os índices epidemiológicos. Em algumas propostas a indicação era de que o usuário e sua família deveriam adotar estilo de vida mais saudável e desenvolver o autocuidado para prevenir complicações advindas do adoecimento. No enfrentamento das doenças infecto-contagiosas, além dos aspectos apontados anteriormente, houve também registro para ações especificas dos serviços de epidemiologia e vigilância sanitária ampliando a 
responsabilidade destes serviços para o controle e acompanhamento dos casos juntamente com os serviços locais.

Um dos avanços identificados nas intervenções aprovadas, ao longo do período, foi no sentido de que alguns agravos cônico-degenerativos passaram a ser monitorados pelo serviço de epidemiologia para fundamentar futuras intervenções, assim como sugerir modificações necessárias nas intervenções desenvolvidas. Ao monitorar determinados agravos, por instrumentos previamente estabelecidos para posterior avaliação e monitoramento dos riscos relacionados ao agravo em questão, foi proposto que os registros dos casos incluíssem variáveis relacionadas às condições sociais, econômicas, educacionais, culturais e ambientais nas fichas de notificação, apesar da predominância do modelo curativista com enfoque no adoecimento.

Discussões sobre intervenções para modificar determinantes e condicionantes sociais do processo saúde-doença foram identificadas em algumas propostas aprovadas, porém na sequência houve retrocesso no avanço que a proposta indicava. Isto porque a maioria das que fizeram referência à determinação social do agravo na sequência, ou seja, em propostas que se seguiu, recomendou intervenção para grupos e indivíduos em risco ou afirmou que os usuários e seus familiares deveriam adotar estilo de vida e autocuidado para evitar o desenvolvimento dos agravos discutidos. Nestes casos, a determinação social do processo saúde-doença foi compreendida como sendo de responsabilidade do indivíduo por adotar determinado estilo de vida.

As exceções ao pensamento predominante nos discursos, já referido acima, foram propostas relacionadas à intervenção nas situações que passaram a ser discutidas na $6{ }^{\text {a }}$ Conferência (2001) e, a partir desta, estiveram presentes nos eventos seguintes. Essas propostas foram relacionadas a intervenções para prevenir a violência contra idoso, mulher, adolescentes e crianças, bem como também, para diminuição dos índices de mortes de adolescentes por causas externas. Nessas propostas se indicou a necessidade de análise ampliada dos casos com identificação de variáveis socioeconômicas relativas à sua determinação. $\mathrm{Na} 7 .{ }^{a}$ Conferência foram aprovadas intervenções direcionadas para o agressor e como intervenção a ser desenvolvida foi proposta a 
criação das Redes de Proteção, nas quais os serviços de saúde participariam em ações preventivas e protetoras juntamente com outros setores - educação, assistência social, segurança, conselho tutelar e movimento social organizado. Contudo, se tem afirmado que a intervenção é para indivíduos e grupos em situações de risco. As variáveis relacionadas às condições sociais e econômicas foram apontadas como fatores favoráveis e desencadeantes da violência e mortes por causas externas. Não houve propostas que indicassem intervenção nos processos determinantes da dimensão estrutural desta realidade.

Os temas considerados como transversais nas Conferências foram aqueles que estiveram presentes em propostas aprovadas para definir intervenções em saúde em todos os eventos e no mesmo evento foram apontados em diversas propostas. Portanto, considerados esses aspectos os temas que mais se destacaram foram: financiamento do setor, organização dos serviços, modelo de intervenção em saúde, intersetorialidade, qualificação dos profissionais, participação popular e formação de conselheiros de saúde.

Quanto ao financiamento do sistema de saúde municipal, pode-se afirmar que a temática foi repetida nas Conferências pela própria fragilidade do setor em garantir recursos para implantar intervenções que eram aprovadas, assim como para dar continuidade àquelas que já eram desenvolvidas. A recomendação para se buscar recursos financeiros junto aos Poderes Legislativos das diferentes esferas de governo, assim como de se garantir o financiamento específico para o desenvolvimento de uma determinada intervenção em saúde foram propostas aprovadas em Conferências. Desse modo, em meio à indefinição de recursos financeiros, presente até o momento nas regulamentações do Sistema Único de Saúde em todo Brasil, propostas que indicaram a ampliação ou implantação de intervenções foram aprovadas sem que houvesse clareza quanto à viabilidade financeira de desenvolvimento.

Em relação aos recursos financeiros na $7 .{ }^{a}$ Conferência (2003) foi aprovada proposta que responsabilizava o Conselho Municipal de Saúde (CMS) pela fiscalização do uso dos recursos aplicados no setor, assim como já havia sido previsto nas regulamentações vigentes desde o início da década de 1990. Em Conferências anteriores não houve registros nesse sentido, logo se acredita que somente a partir desse período o Conselho 
Municipal de Saúde passou a exercer a atribuição ou que a partir desse evento a atribuição foi oficializada no setor.

Quanto à organização dos Serviços de Saúde no município, as propostas que continham este conteúdo apontaram a necessidade de serem estabelecidas diretrizes norteadoras das intervenções desenvolvidas pelos profissionais dos serviços nos diferentes níveis de complexidade da atenção à saúde. Nesta perspectiva na 6 . $^{\text {a }}$ Conferência foi aprovada a criação do Sistema Integrado de Serviços (SIS) para que fossem desenvolvidas intervenções integradas nos diferentes níveis do sistema e, consequentemente, mais efetivas.

Quanto à definição das diretrizes para a organização foi aprovado que as gestões dos serviços públicos e dos serviços conveniados deveriam seguir os princípios e diretrizes estabelecidos no SUS ao desenvolver intervenções sob suas responsabilidades. Segundo esses pressupostos, as propostas aprovadas reivindicavam: definição do modelo de atenção a saúde a ser desenvolvido nos serviços; a articulação com outros setores para o desenvolvimento de intervenções em conjunto - intersetorialidade; adequação de infraestrutura dos serviços de saúde para a ampliação da cobertura da atenção à saúde e garantia de acesso para usuários; contratação de profissionais por meio de concurso público para aumentar o quadro existente, bem como inserir novas categorias no processo de trabalho em saúde, entre outras questões.

A reversão do modelo de assistência foi apontada em todas as Conferências e em diversas áreas discutidas, ou seja, este tema era abordado tanto quando se referia a intervenções para o enfrentamento de um determinado adoecimento ou quando se referia à intervenção em saúde para indivíduos que se encontravam em determinada fase do ciclo de vida. Nesse sentido, o modelo de atenção preconizado ao longo do período (1997-2007) foi direcionado para a programação em saúde seguindo os programas estabelecidos pelo Ministério da Saúde. Ao aprovar a implantação dos programas buscava-se reverter os problemas que fundamentaram as próprias propostas de intervenção. Em propostas aprovadas também foi recomendada a adoção e atualização de protocolos clínicos para atender às mudanças ocorridas nos processos de trabalhos do setor e melhorar a 
eficácia das intervenções em saúde. Com esse enfoque, na $6^{\text {a }}$ Conferência foi proposta a implantação da consulta de enfermagem nos programas desenvolvidos na atenção básica à saúde como uma estratégia de reversão do modelo de assistência.

$\mathrm{Na}$ implantação e atualização dos protocolos para a sistematização da assistência à saúde no município, a Secretaria Municipal de Saúde foi inovadora em algumas questões ao longo destes anos e implantou programas pioneiros. Entre as inovações estão o Programa Mãe Curitibana, a Classificação Internacional das Práticas de Enfermagem em Saúde Coletiva (CIPESC®), o prontuário eletrônico único, o sistema de notificação de doenças on line e as redes de proteção para as vítimas de violência e maus tratos.

Outro avanço na reversão do modelo de assistência identificado nas intervenções aprovadas está relacionado aos princípios da intersetorialidade e a integralidade presentes em algumas propostas que buscavam dar conta de atender às necessidades em saúde da população além dos aspectos biológicos do problema. Porém, a maioria das propostas aprovadas foi de caráter curativista e de intervenção individual deixando os avanços indicados reduzidos e direcionados para temas específicos, como já referidos anteriormente.

A qualificação dos profissionais inseridos nos processos de trabalho dos serviços da Secretaria foi apontada em um grande número de propostas aprovadas nas Conferências. A necessidade de aperfeiçoar o conhecimento profissional para atender à organização e às especificidades das intervenções desenvolvidas nos serviços públicos e em serviços credenciados foi apontada no sentido de que a qualificação permitiria a reversão do modelo de assistência desenvolvido. Segundo os relatórios analisados, pode-se considerar que o modelo desejado era baseado na programação em saúde com o desenvolvimento de atividades estabelecidas nos protocolos. Assim, acredita-se que a qualificação referida nas diferentes propostas tinha o objetivo de instrumentalizar os profissionais para intervir segundo os programas e protocolos referendados pela gestão do setor.

Outras questões foram objetos de propostas aprovadas relacionadas aos profissionais de saúde. Entre elas encontram-se a implantação de Plano de Cargos e Salários e o desenvolvimento de programas de educação permanente 
para profissionais inseridos nos serviços de saúde municipais. Essas questões foram indicadas em propostas aprovadas nas Conferências, porém, nos mesmos eventos também foram aprovadas propostas de articulação para se efetivar a parceria entre a Secretaria de Saúde e os Hospitais Universitários, públicos e privados, para a ampliação da assistência nos serviços de urgências clínicas e emergências (atenção pré-hospitalar). Logo, as propostas de parcerias aprovadas atenderiam às necessidades imediatas de ampliação dos serviços para aumento de cobertura de determinadas intervenções, mas consequentemente comprometiam a ampliação do quadro de profissionais por meio de concurso público conforme indicavam propostas aprovadas. Portanto, as perspectivas relacionadas à ampliação de quadro, inserção de novas categorias, qualificação dos profissionais foram comprometidas pela lógica da terceirização dos serviços que se iniciava.

O controle social foi tema de propostas em todas as Conferências, coerente pela própria importância da participação dos movimentos sociais na elaboração, organização e efetivação do evento. As preocupações registradas foram no sentido de que haveria necessidade de se qualificar usuários para a participação nos diferentes espaços colegiados, nos quais este segmento discute as necessidades em saúde da população e as Políticas Públicas que deveriam ser aprovadas para atender-Ihes. Porém, tal formação ou qualificação foi apontada para ser desenvolvida pela própria gestão dos serviços de saúde por meio de projetos de educação permanente. O curso preparatório, segundo as propostas aprovadas, seria para os conselheiros em exercício da função e para cidadãos candidatos a ela. Além disso, as propostas apontaram que haveria necessidade de organização do curso com relação aos conteúdos a serem desenvolvidos, assim como de certificar a participação dos alunos.

A seguir é apresentada síntese dos temas abordados nos dez anos de Conferência Municipal de Saúde de Curitiba e as dimensões da realidade estrutural, particular e singular - nas quais estes foram discutidos. 
Quadro 1 - Temas de propostas nas Conferências Municipais de Saúde de Curitiba do período de 1997 a 2007, segundo as dimensões da realidade - estrutural, particular e singular, Curitiba- PR - 2009

\begin{tabular}{|c|c|}
\hline & Temas abordados nas conferências \\
\hline 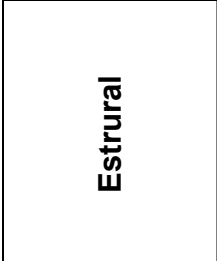 & $\begin{array}{l}\text { - Financiamento do Sistema Único de Saúde; } \\
\text { - Participação popular a definição de Políticas Públicas para o setor; } \\
\text { - Concepções de saúde e doença nas Políticas Públicas para o setor; } \\
\text { - Princípios do SUS na definição das intervenções em saúde: integralidade, } \\
\text { intersetorialidade, acessibilidade; } \\
\text { - Modelo de atenção à saúde preconizada pelo SUS - promoção da saúde, prevenção } \\
\text { do adoecimento respeitando os princípios e as diretrizes estabelecidos. }\end{array}$ \\
\hline 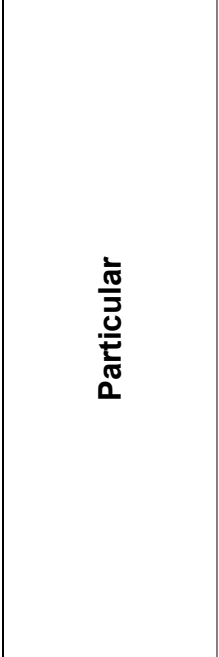 & $\begin{array}{l}\text { - Financiamento das intervenções em saúde no Município; } \\
\text { - Organização dos serviços de saúde no Município para garantir os princípios e diretrizes } \\
\text { do sistema; } \\
\text { - Modelo de atenção à saúde desejado - atendimento integral, intersetorial, descentralizado, } \\
\text { - resolutivo e baseado nos dados populacionais, epidemiológicos e sanitários; } \\
\text { - Modelo de atenção à saúde implantado - programação em saúde com enfoque em } \\
\text { grupos e indivíduos de risco para o adoecimento ou agravo; } \\
\text { - Organização do movimento social para efetivar a participação popular no sistema de } \\
\text { - saúde local; } \\
\text { - Programas e protocolos de saúde para definição de intervenções e responsabilidades } \\
\text { - dos gestores, profissionais, famílias e usuários; } \\
\text { - Ampliação de cobertura dos programas na atenção básica à saúde; } \\
\text { - Implantação de serviços de atenção básica (PSF) e pré-hospitalar (SIATE e SAMU); } \\
\text { - Parcerias com as Universidades, públicas e privadas, para ampliação da cobertura dos } \\
\text { serviços de urgência e emergência - atenção pré-hospitalar, início da terceirização } \\
\text { da força de trabalho; } \\
\text { - Qualificação e expansão do quadro de profissionais dos serviços públicos e } \\
\text { credenciados para a reversão do modelo de assistência. }\end{array}$ \\
\hline 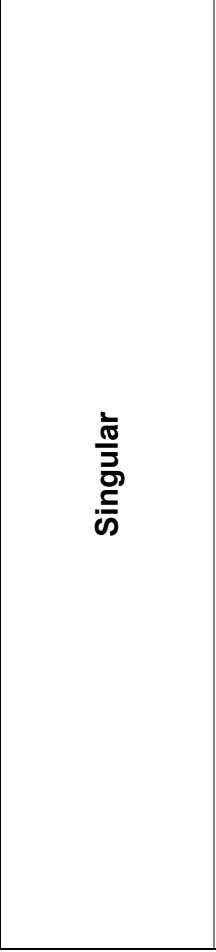 & $\begin{array}{l}\text { - Reconhecimento de adoecimentos segundo grupos populacionais e mudanças no } \\
\text { ciclo de vida dos usuários; } \\
\text { - Identificação de grupos de risco, segundo dados populacionais, epidemiológicos e } \\
\text { sanitários; } \\
\text { - Modelo de atenção à saúde referendado pela SMS - programação em saúde com } \\
\text { implantação de protocolos; } \\
\text { - Organização do processo de trabalho nos serviços de saúde dos diferentes níveis de } \\
\text { atenção à saúde para o enfrentamento aos agravos identificados; } \\
\text { - Ampliação do quadro de funcionários e inserção de novas categorias profissionais } \\
\text { nos serviços municipais de saúde; } \\
\text { - Intervenções direcionadas a grupos em risco de adoecer; } \\
\text { - Intervenções de caráter preventivo com responsabilização do usuário e família para } \\
\text { a adoção de estilo de vida saudável e desenvolvimento de autocuidado; } \\
\text { - A equipe de saúde local co-responsabilizada pela adoção das mudanças de estilo de } \\
\text { vida e autocuidado dos usuários e famílias; } \\
\text { - Modificação dos índices epidemiológicos e sanitários indicando controle de alguns agravos; } \\
\text { - Ampliação de cobertura das intervenções em saúde; } \\
\text { - Parcerias com instituições de ensino para implantar algumas intervenções pré- } \\
\text { hospitalares início do processo de terceirização da força de trabalho; } \\
\text { - Reorganização da preparação das conferências municipais com o desenvolvimento } \\
\text { de conferências locais e distritais de saúde; } \\
\text { - Ampliação das temáticas discutidas nas Conferências Municipais de Saúde, porém a } \\
\text { maioria das propostas teve enfoque no desenvolvimento de intervenções para } \\
\text { reverter ou prevenir complicações de adoecimento e (ou) mudanças do ciclo de vida; } \\
\text { - Número de participantes na plenária da Conferência Municipal quase constante nos } \\
10 \text { anos. }\end{array}$ \\
\hline
\end{tabular}

Fonte: Relatórios das Conferências Municipais de Saúde de Curitiba-PR (Conselho Municipal de Saúde, Curitiba, 1997, 1999a, 2001, 2003, 2005b, 2008c) 


\subsubsection{A organização das Conferências e o número de participantes}

No período de dez anos de Conferências os relatórios indicam mudanças na forma de organização das Conferências. No discurso da $4 .^{a}$ Conferência não se registraram momentos de discussão coletiva que antecedessem a plenária da Conferência. Posteriormente os registros mostraram significativa modificação no sentido de garantir momentos coletivos antecedentes à Conferência para a ampliação de discussões e elaboração de propostas.

Assim, foram realizados cursos, conferências locais e distritais, anteriores à plenária da Conferência Municipal garantindo a lógica ascendente de participação. Os registros demonstram que esses momentos aumentaram significativamente ao longo do período, logo se acredita que houve distribuição de oportunidades para a participação do movimento social organizado em todo o território municipal no sentido de discutir a realidade de saúde. Porém, os registros demonstram também que o número de participantes na plenária das Conferências foi quase constante, apesar do aumento da população geral do município nos últimos anos, da organização ascendente com momentos preparatórios e do aumento de propostas aprovadas para preparar usuários para participar efetivamente nos espaços, estes garantidos pelas regulamentações, para a definição das Políticas Públicas do setor.

As exceções quanto ao número de participante ficou para a 4. ${ }^{a}$ Conferência que não registrou a presença de delegados e observadores na plenária e nos registros da $6 .{ }^{a}$ Conferência Municipal, nos quais se pode verificar o decréscimo no número de participantes (534 participantes). Neste último caso o fato pode ser atribuído à forma de registro que foi somente para aqueles que eram delegados na plenária, mas também pode ter sido um decréscimo real no número de participantes no evento por desmobilização ou momento político. Porém, no relatório não houve comentário sobre o fato e nem sobre o critério para se registrar o número de participantes.

A figura a seguir demonstra a distribuição do número de participantes nas plenárias das Conferências, conforme os relatórios analisados. A questão que nos faz refletir é que nas plenárias das Conferências se discutem e 
aprovam as propostas de Políticas Públicas para a intervenção do setor. Assim, apesar do movimento ascendente de participação e elaboração de propostas, a aprovação ficou sob a responsabilidade de um número quase constante de delegados ao longo dos dez anos estudados.

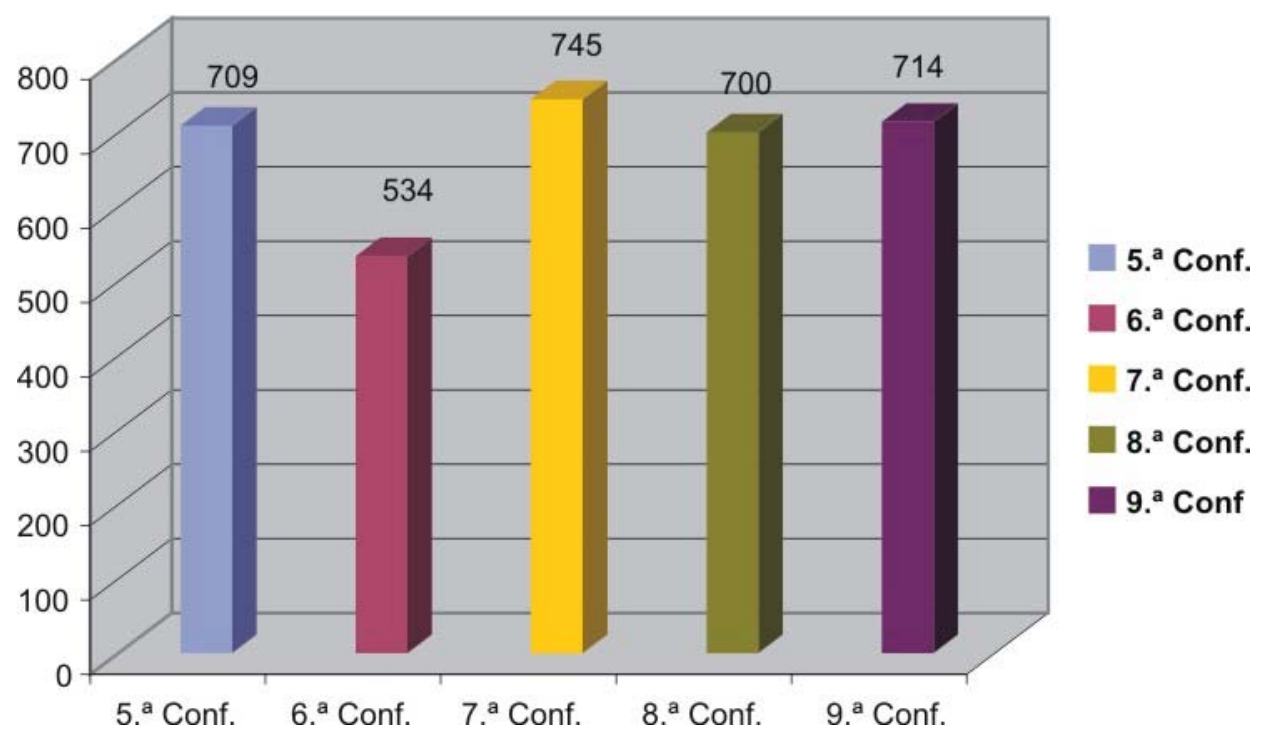

Figura 15 -Distribuição do número de participantes, delegados, convidados e observadores, nas Conferências Municipais de Curitiba-PR no período de 1997 a 2007

Fonte: Relatórios das Conferências Municipais de Saúde de Curitiba-PR (Conselho Municipal de Saúde, Curitiba, 1997, 1999a, 2001, 2003, 2005b, 2008c).

Cabe registrar que em todos os relatórios são identificadas características nas propostas aprovadas que denotam um discurso bastante técnico. $\mathrm{Na}$ 6. ${ }^{a}$ Conferência esse fenômeno fica bastante evidente, pois as propostas parecem prescrever intervenções de tão similares que são. Outra característica é que as intervenções passaram a ser mais especificadas e abrangentes para determinados temas, mas estes estão relacionados a adoecimentos e mudanças no ciclo de vida, discurso que é de técnicos ou gestores do sistema de saúde e não do movimento social organizado.

Portanto, alguns avanços que foram observados podem ter sido pela influência direta de técnicos e gestores na elaboração das propostas e não por organização do movimento social representante da população que vive a realidade de saúde e que tem a dimensão do seu sofrimento quando a ineficiência do sistema público de saúde não consegue reconhecer e enfrentar suas necessidades em saúde. 
Nesse sentido, a relevância de promover cursos de capacitação com referenciais teóricos que possibilitem aos conselheiros e profissionais de saúde refletir criticamente a realidade nas dimensões que a conformam e, assim, serem capazes de identificar a determinação social do processo saúde-doença. Outro aspecto relevante nesta questão é que estes sujeitos possam exercer seus papeis com autonomia.

\subsection{OS PROTOCOLOS - O DISCURSO DA SECRETARIA MUNICIPAL DE SAÚDE PARA A INTERVENÇÃO EM SAÚDE}

Para compreender o discurso dos programas e protocolos vigentes na Secretaria Municipal de Saúde de Curitiba foram levantados os documentos e as publicações disponíveis no site da instituição. Foram encontrados vinte e seis documentos que normatizam e orientam intervenções a serem desenvolvidos nos serviços de saúde; nestes foram analisados os discursos para refletir sobre suas fundamentações teóricas para a organização da intervenção na rede de serviços públicos e contratados do setor saúde no território municipal.

No início da busca dos documentos, protocolos e manuais, pesquisaram-se no site da Secretaria de Saúde aqueles que estavam identificados no link "protocolos". Depois desta primeira fase da análise foram identificados nos discursos do material levantado outros documentos que eram referenciados; assim, nova busca foi realizada para completar os documentos que representavam as diretrizes das intervenções no setor. Ao se identificar todos os documentos de interesse, estes foram arquivados em uma pasta para posterior análise.

Com o conjunto de protocolos e manuais foram selecionados aqueles que tinham como objetivo normatizar as intervenções dos serviços para atender às necessidades em saúde dos usuários, assim se compôs o grupo dos 26 documentos analisados. Para compreender o discurso, os documentos foram agrupados segundo temas e na apresentação da síntese, quadro 
abaixo, iniciou-se por aqueles com temáticas mais frequentes. Neste caso, os documentos com temas relacionados à criança, à mulher e, por fim, os demais protocolos.

Para os documentos que tinham duas versões foi considerada a versão mais atualizada para a análise. Nessa fase do estudo, ao proceder à análise foram considerados os resultados dos discursos que fazem parte deste estudo: entrevistas com enfermeiros da atenção básica do Distrito Sanitário Boa Vista, caracterização do município de Curitiba e relatórios das Conferências Municipais de Saúde ocorridas nos últimos dez anos. Portanto, os documentos que não foram relacionados às temáticas abordadas e apresentavam normas técnicas para execução de procedimentos não foram analisados.

Quadro 2 - Análise do discurso nos protocolos vigentes na Secretaria Municipal de Saúde - CuritibaPR - 2009

\section{Documento:}

Protocolo da Rede de Proteção à Criança e ao Adolescente em Situação de Risco para a Violência. Secretaria Municipal de Saúde, Curitiba, 2008d.

\section{Interpretação:}

O protocolo foi apresentado como resultado de lutas de movimentos organizados, desde o avanço em regulamentações como também dos movimentos sociais organizados. Foi apontado que a ação deveria ser integrada, intersetorial com a participação de instituições governamentais e não governamentais. Como regulamentação destacou-se a n. ${ }^{\circ} 8.069$ de 13/07/09. O objetivo da criação da Rede de Proteção foi o de estabelecer o protocolo para se prevenir e inibir a violência contra a criança e o adolescente. Para prevenir seria necessário detectar as situações de risco para a violência. Acompanhar os casos de violência foi considerado a maneira de se inibir a reincidência, neste sentido havia necessidade de dar suporte às vítimas e aos autores da violência para que esses pudessem superar as causas e atenuar as seqüelas. Os dados epidemiológicos sobre violência foram referidos como base para se estabelecer a proposta de intervenção. A causa da violência foi identificada como algo que pertence à cultura da população. As penalidades aplicadas pelas famílias aos menores foram referidas como algo histórico e cultural. Entre os desafios para o desenvolvimento do programa foram apontados: o trabalho integrado, novos paradigmas para se analisar a realidade e a busca de soluções para as questões a serem enfrentadas. No protocolo registrou-se que a violência intrafamiliar era considerada como tema protagonista e a metodologia do trabalho em rede como o tema coadjuvante (p.24);

Violência foi referida como sendo conceituada segundo o Relatório Mundial sobre a Violência e Saúde OMS (2002) (p.31). Ao apontar as estratégias de enfrentamento às questões de violência foram referidas ações para a prevenção baseada em dados epidemiológicos, principalmente junto às famílias. Não houve referência sobre intervenções na determinação da violência (p.39). As estratégias de intervenção foram apontadas com base no cumprimento das regulamentações e normatizações das diferentes esferas de governo.

Para a composição da rede local foi registrado que haveria a participação de profissionais de saúde representantes de instituições públicas e conveniadas, sendo que estes deveriam cumprir a exigência de terem feito capacitação, bem como ter atuação comprometida com a Rede de Proteção (p.44). Ao apontarem as estratégias de ação para a prevenção (p.44) afirmou-se que estas deveriam considerar as situações de risco para a violência vivida por crianças, adolescente e suas famílias. Neste caso, foi referendado o conceito de risco que permeou toda a discussão do protocolo. Ainda nas estratégias de ação percebe-se que houve preocupação constante com os aspectos éticos relacionados aos casos identificados com recomendação para se garantir o sigilo e anonimato dos envolvidos. Para orientar os profissionais, estabeleceram-se critérios para a observação de sinais indicativos de violência

continua 
continuação

Quadro 2 - Análise do discurso nos protocolos vigentes na Secretaria Municipal de Saúde - CuritibaPR - 2009

intrafamiliar e nestes foram encontrados critérios sociais, ou seja, famílias que não teriam condições econômicas para o atendimento às necessidades básicas dos seus membros. Chama a atenção no documento que ao referir à falta de possibilidade da família em atender a necessidades básicas dos sujeitos que a compõem não foi apontado quais seriam as determinações sociais e econômicas desse processo. Na sequência do documento foi registrado que adultos que praticam a violência contra crianças e adolescentes alegam ter problemas com desemprego, como anteriormente neste momento do documento também não se fez referência à determinação social e econômica do fenômeno (p.49-50).

Para se identificar as evidências da violência foram referidos vários parâmetros de comportamento pessoal, assim como a observação de sinais e sintomas clínicos. Neste caso, chamou a atenção que, apesar de se fazer referência, no início do documento, de que a proposta de ação para a prevenção da violência era intersetorial e interinstitucional, as evidências, ou seja, os sinais da violência foram indicados como sendo possíveis de serem percebidos em procedimentos médicos e odontológicos.

O protocolo foi proposto para intervenções a serem desenvolvidas pelo setor saúde, mas neste caso a contradição é que na própria rede de serviços públicos existem outros profissionais que também poderiam observar sinais de violência nas vítimas.

O grau de gravidade do risco para a violência foi apontado de acordo com um critério de pontuações para fatores observados e posteriormente o somatório destes indicaria o grau de risco - leve, moderado, grave - por fim, o documento registrou a necessidade de os profissionais utilizarem o bom senso na avaliação dos riscos à violência. Para promover a intervenção, o documento referenda que deve ser considerado o grau de gravidade para indicar a urgência dos procedimentos a serem adotados (condutas e fluxo- p.71-3). Quanto à classificação da natureza da violência foram referidas as diferentes formas e entre elas foi apontado que questões estruturais como violência que priva os adolescentes e as crianças das condições que lhes proporcionariam crescimento e desenvolvimento adequados uma vez que suas necessidades não seriam atendidas (p.85). Na sequência o documento apresentou a classificação da violência segundo os tipos que podem ser encontradas - intrafamiliar, extrafamiliar, autoinfligida ou autoagressão, fetal ou ignorada. Neste caso não houve classificação convergente à violência pelas condições socioeconômicas, pois extrafamiliar foi relacionado à comunidade e instituições com as quais o sujeito se relaciona diretamente - dimensão particular da realidade do sujeito.

Quanto à responsabilidade da agressão, o protocolo fez referência a situações relacionadas à responsabilidade dos pais ou responsáveis, mas não referiu quando a responsabilidade seria atribuída ao Estado ou Sociedade - no caso da violência por determinantes estruturais. Para a avaliação do caso, suspeito ou confirmado, foi apontado que estas seriam contínuas pela Rede de Referência.

Quanto ao Sistema de Garantia de Direitos para o atendimento das necessidades básicas das crianças e dos adolescentes, foi apontado que este estava vinculado às diferentes instituições governamentais e não-governamentais que compõem o sistema. Como objetivo do Sistema foi registrado - promover e garantir Políticas Públicas que venham a atender às necessidades das crianças e adolescentes. A família foi apontada como a base para todo o atendimento às necessidades das crianças e adolescentes, assim como pelo processo de formação destes sujeitos.

O conceito de família adotado no protocolo (p.116) demonstrou um avanço por reconhecer família como um grupo social que historicamente tem se modificado e que um núcleo social é uma família estabelecida, além dos laços sanguíneos entre pessoas. Família são indivíduos que convivem em um mesmo local e trocam sentimentos no sentido de se ajudar e se cuidar em uma determinada sociedade, em um determinado tempo histórico e de acordo com as relações de produção e reprodução social ali existente.

O empoderamento da família para uma convivência saudável e independência de diferentes profissionais para o enfrentamento às suas questões foi apontado como uma ação preventiva (p.121). A resiliência também foi apontada no protocolo, no sentido de compreender que alguns sujeitos têm a possibilidade de superar situações de violência e trauma e seguir na vida nos padrões de normalidade. Para se ter essa possibilidade de superação se indicou a necessidade de apoio a esses sujeitos nos diferentes espaços - família, escola e comunidade (p.129);

Para a superação há que se ter clareza sobre a raiz dos problemas a serem enfrentados - ao afirmar esta proposta se colocou no protocolo como fazer e nesse sentido foram apontadas maneiras individuais de se enfrentar as raízes das questões. As creches, escolas e universidades foram consideradas como espaços para se identificar temas de interesse para discussão na comunidade no sentido de prevenir e combater a violência. Para elaborar estas atividades, os temas a serem discutidos deveriam vir da realidade vivida pela comunidade (p.124). O esforço para a paz deveria ser dos indivíduos e seus coletivos, no sentido de superar as adversidades e estabelecer um clima harmônico de convivência (p.126); 
continuação

Quadro 2 - Análise do discurso nos protocolos vigentes na Secretaria Municipal de Saúde - CuritibaPR - 2009

\begin{abstract}
Documento:
Saúde e prevenção nas escolas: a experiência de Curitiba. Secretaria Municipal de Saúde, Curitiba, 2005c.

Interpretação:

O programa foi iniciado em 19 de agosto de 2003 e teve como objetivos: desenvolver ações de educação continuada nas escolas para prevenir as doenças sexualmente transmissíveis, a gravidez na adolescência, estimular o uso de preservativos masculino e prevenir a violência. Os dados utilizados para justificar a proposta foram da base de dados epidemiológicos sobre a infecção por HIV/aids, gravidez na adolescência, a feminilização da epidemia do HIVIAIDS. Outras bases para justificar a proposta foram as regulamentações sobre os direitos da criança e do adolescente, os dados populacionais de Curitiba, nos quais se identificou que $28 \%$ da população curitibana era de jovens de 10 a 19 anos e $9,86 \%$ de 20 a 24 anos e, ainda, havia a necessidade de ampliar e tornar prioritário programas de educação à saúde no Governo Municipal atendendo às recomendações do Governo Federal. Para a seleção de temas a serem trabalhados, além dos dados já apontados acima, buscou-se ouvir os sujeitos participantes do processo por meio de grupos focais.

O conteúdo dos grupos focais foram norteadores dos treinamentos realizados com os professores a serem envolvidos nas ações de educação à saúde. O protocolo referiu sobre a desigualdade social e de gênero como um dos fatores de risco para a infecção para o HIV, mas este não foi um dos temas ressaltados nos grupos focais com os adolescentes (cap. 7, p.19). O desenvolvimento das ações de educação à saúde contava com os profissionais de saúde, professores, funcionários e familiares de crianças e adolescentes matriculados em escolas de ensino fundamental e médio da rede pública de ensino.

A expectativa era de atender no primeiro período por volta de 5.000 (cinco mil) estudantes. A distribuição de camisinhas tinha a previsão de oito camisinhas por aluno ao mês, 160.000 (cento e sessenta mil) preservativos ao mês. No histórico de ações de educação à saúde para jovens matriculados em escolas públicas com temáticas voltadas para a sexualidade o documento registrou que existiam programas desenvolvidos desde o ano de 1996. No discurso foi apontado que as ações de educação à saúde e Políticas Públicas comprometidas com o enfrentamento destas questões possibilitariam aos adolescentes uma mudança de vida para a adoção de estilo de vida mais saudável. Esta justificada pela possibilidade de os sujeitos terem a chance de adotar medidas de proteção e autocuidado, uma vez que estariam cientes dos riscos para as doenças sexualmente transmissíveis, assim como para a gravidez na adolescência. Para o desenvolvimento das ações junto às escolas referiu-se que era necessário considerar a realidade de cada uma. Foi registrado que as resistências aos projetos vieram com estas temáticas, na grande maioria, foram da Igreja Católica. Para avançar na implantação do protocolo, os técnicos tiveram que contornar a situação e elaborar justificativas mais técnicas.
\end{abstract}

\title{
Documento:
}

Nascer em Curitiba. Informações importantes para seu filho. Secretaria Municipal de Saúde, Curitiba, data desconhecida.

\section{Interpretação:}

Esta é uma publicação em formato de cartilha, dirigida aos pais, com orientações sobre cuidados de saúde, amamentação, alimentação e higiene para o recém-nascido, contendo também os endereços completos das Unidades de Saúde do Município.

\section{Documento:}

Alimentação infantil- cartilha de orientação aos pais. Secretaria Municipal de Saúde, Curitiba, 2007b. Interpretação:

É um protocolo que tem como propósito estabelecer orientações para pais, cuidadores e familiares sobre a seleção e higiene dos alimentos para a alimentação adequada das crianças no sentido de promover o seu crescimento e desenvolvimento.

Nas orientações estimulam-se o aleitamento materno exclusivo até o sexto mês de vida e a introdução de alimentos naturais segundo a idade da criança. Têm-se, ainda, orientações para prevenir distúrbios alimentares, assim como suas consequências. Entre os distúrbios, destacam-se desnutrição, obesidade e diarréias. 
continuação

Quadro 2 - Análise do discurso nos protocolos vigentes na Secretaria Municipal de Saúde - CuritibaPR - 2009

\section{Documento analisado:}

Crescendo com Saúde: infecções e alergias respiratórias na infância. Secretaria Municipal de Saúde, Curitiba, 2000a.

\section{Interpretação:}

O objetivo do protocolo é padronizar condutas diante de doenças respiratórias da infância nos atendimentos dos serviços de saúde para modificar os dados de morbi-mortalidade pediátricos no município. Entre estes foram destacados que $50 \%$ da demanda para consulta ambulatorial, quase $25 \%$ das causas de internamento hospitalar, $9,5 \%$ de óbitos em menores de 14 anos estavam relacionados às doenças respiratórias da infância (p.11-2).

A proposta deste protocolo está fundamentada no modelo de atenção à saúde que prioriza intervenções sobre os fatores de riscos relacionados à dimensão singular - características biológicas do indivíduo, do meio em que ele vive e do agente etiológico, assim como sinais e sintomas observados no doente. As intervenções para prevenção e tratamentos ficaram restritas aos fatores apontados: indivíduo, meio e agente etiológico.

\section{Documento:}

Protocolo de atenção à saúde do adolescente. $2 .^{a}$ ed revista e atualizada. Secretaria Municipal de Saúde, Curitiba, 2006c.

\section{Interpretação:}

Na apresentação do documento foi referido que este é uma atualização da versão anterior datada de 2002, pois na época havia se pensado em um programa com ações voltadas para um grupo populacional concebido como saudável. Todavia com a atualização dos dados de morbimortalidade se percebeu que este grupo necessitava de outras intervenções do setor saúde e estas deveriam ser de caráter intersetorial e interinstitucional para dar conta dos problemas relacionados à morte por causas externas, contaminação por DST, gravidez indesejada, AIDS, abuso de drogas lícitas e não lícitas, acidentes e violência. A faixa etária considerada como adolescente pelo programa foi de 10 a 20 anos incompleto, parâmetro que seguiu ao recomendado pela Organização Mundial de Saúde e Ministério da Saúde.

Os dados epidemiológicos que foram apresentados estimaram a população de adolescentes e jovens (10 a 24 anos) da cidade de Curitiba, por volta em 462.966 indivíduos, o que correspondia a $28,33 \%$ da população total do município. $\mathrm{Na}$ análise sobre os referidos dados se viu a necessidade de rever a posição do programa e enfrentar questões consideradas graves como indicou o documento. Essas situações se referiram mais especificamente aos índices de mortalidade de adolescente (10 a 19 anos) do sexo masculinos por causas externas, no período de 1998 a 2004. Para os meninos os índices eram maiores que os referentes às de adolescentes do sexo feminino. Neste último grupo se teve um número significativo de casos de óbitos por gravidez, parto e puerpério, apesar das causas externas ainda serem a maior causa de mortes. Nos dados observa-se ainda que no grupo feminino a maior causa de internação hospitalar foi por gravidez, parto e puerpério. Para os adolescentes do sexo masculino a tendência da morbidade para internação seguiu as causas de morte, ou seja, as morbidades por causas externas foram a primeira causa das internações hospitalares. Neste sentido, no protocolo, foram estabelecidos os critérios para se identificar as situações de risco no grupo para promover intervenções em saúde.

Nos critérios estabelecidos foram considerados riscos biológicos, emocionais, familiares e sociais. As condições relacionadas à crise econômica, ao desemprego, desamparo social e familiar e a violência intrafamiliar e fora do domicílio foram citadas como determinantes das questões a serem enfrentadas.

Para a intervenção, o adolescente deveria ser considerado como sujeito capaz de refletir sobre o processo pelo qual estava passando e também sobre sua determinação. O setor de educação, por meio das escolas nas quais os adolescentes se inserem, foi apontado como um parceiro para as ações de promoção da saúde e prevenção dos agravos. Nessa perspectiva, outros parceiros destacados foram os pais e a família. Os trabalhos deveriam buscar construir relação de confiança e apoio entre os envolvidos, inclusive com o profissional de saúde, professores e funcionários das escolas. A resiliência foi o conceito que permeou as ações propostas. Baseado neste conceito se considerou o adolescente como sujeito capaz de superar as adversidades de sua vida, individualmente, em grupo, com o apoio da família, comunidade e dos profissionais de educação e da saúde. Nas ações de assistência à saúde foi proposto considerar o adolescente como indivíduo em pleno desenvolvimento físico, emocional, 
continuação

Quadro 2 - Análise do discurso nos protocolos vigentes na Secretaria Municipal de Saúde - CuritibaPR - 2009

sexual, como também capaz de amadurecer perante às questões da vida, logo foram propostas ações multiprofissionais e intersetoriais tendo a família como parceira nesse processo. Foram orientadas condutas clínicas e de apoio diagnóstico para os adoecimentos mais comuns, organização do serviço para o atendimento à clientela e sistema de informação gerencial. Outras orientações foram sobre os aspectos relacionados à nutrição adequada, imunização e ética relacionada ao atendimento de adolescentes nos serviços de saúde.

\section{Documento:}

Planejamento familiar - Programa Mãe Curitibana. Secretaria Municipal de Saúde, Curitiba, 2005d.

Interpretação:

O objetivo do programa registrado no documento foi de promover ações que diminuíssem as taxas de morbi-mortalidade materna e infantil. As intervenções deveriam ser articuladas às ações do protocolo do Programa Mãe Curitibana na assistência ao pré-natal, parto e puerpério e, ainda, integrar-se às intervenções estabelecidas pelo protocolo sobre o adolescente saudável.

As ações deveriam ser direcionadas às demandas relacionadas à pré-concepção, infertilidade e anticoncepção. Os grupos de risco seriam prioritários nas intervenções e que ao promover as intervenções propostas se promoveria a cidadania por meio da informação para a escolha de uma vida sexual saudável e de métodos contraceptivos ou tratamentos para a infertilidade com o acompanhamento da equipe de saúde, segundo os critérios preestabelecidos.

O protocolo apresentou ainda os problemas de saúde mais comuns na população-alvo e as condutas clínicas a serem seguidas pela equipe de saúde. Foram especificadas atividades que competiam a cada profissional (p.85). Por fim, apontou os critérios para a indicação de esterilização por meio da ligadura de trompa e vasectomia.

\section{Documento:}

Programa Mãe Curitibana: pré-natal, parto, puerpério e atenção ao recém-nascido. Secretaria Municipal de Saúde, Curitiba, 2004a.

\section{Interpretação:}

O protocolo analisado era uma revisão e atualização do Programa Mãe Curitibana. Registrou-se que a mudança apontada nessa edição foi que a proposta orientava para o desenvolvimento de intervenções multidisciplinares em um sistema integrado de serviços nos diferentes níveis de complexidade de atenção à saúde no município.

O objetivo indicado era diminuir os índices de morbi-mortalidade do ano de 2002 que registraram a mortalidade materna como 26,6 óbitos/ 100.000 nascidos vivos e mortalidade infantil com 11,8 óbitos por 1000 nascidos vivos com a melhora da assistência à saúde das gestantes e aos recém-nascidos.

Outros objetivos destacados foram: fortalecer os laços com a comunidade e desenvolver cursos de atualização para os profissionais envolvidos com o programa.

A Unidade de Saúde foi referida como a porta de entrada no Sistema de Saúde Municipal para as usuárias que buscavam assistência pré-natal. Para que a equipe desenvolvesse a assistência preconizada pelo programa foram propostos critérios de avaliações clínicas com condutas terapêuticas e atribuições para cada profissional.

No protocolo destacaram-se os riscos biológicos para a mulher na gravidez e puerpério, como também para o recém-nascido; assim, ao se observar os parâmetros estabelecidos para riscos, os profissionais deveriam promover as intervenções indicadas, seguir os fluxos estabelecidos e, consequentemente, garantir a vida saudável dos usuários. 
continuação

Quadro 2 - Análise do discurso nos protocolos vigentes na Secretaria Municipal de Saúde - CuritibaPR - 2009

\section{Documento:}

Programa Viva Mulher em Curitiba: controle do câncer de mama e colo de útero. Secretaria Municipal de Saúde, Curitiba, 2002a.

\section{Interpretação:}

O protocolo analisado era a atualização de orientações para o controle do câncer de colo de útero e mama do programa que foi implantado em 1997 no município. A justificativa para tal se deveu aos resultados positivos das intervenções desenvolvidas que levaram à queda dos índices de mortalidade pela neoplasia de colo de útero e aumento nos índices de câncer de mama. Este último fenômeno foi justificado pelos autores pelo uso de tecnologias aplicadas no diagnóstico.

A aplicação do avanço tecnológico no diagnóstico possibilitou a identificação da doença precocemente e com isso registrou índices mais elevados da doença no município no período de 1996 a 2001. Nas orientações o protocolo estabeleceu procedimentos e técnicas para serem adotados nos serviços de saúde, de acordo com o nível de complexidade instalado em cada um dos serviços.

Ainda de acordo com a complexidade dos serviços, estabeleceu-se a responsabilidade para a prevenção, o diagnóstico e o tratamento do câncer de colo de útero e de mama. Não registrou responsabilidade por profissional de saúde nas intervenções.

\section{Documento:}

Atenção à saúde da mulher em situação de violência: Curitiba levada a sério. Secretaria Municipal de Saúde, Curitiba, 2008e.

\section{Interpretação:}

O protocolo foi proposto para atualizar o protocolo versão 2004 e, assim, atenderia também às novas regulamentações na assistência à mulher vítima de violência. Foi referido que com a nova proposta buscam-se integrar as ações do setor saúde com o setor da justiça e com entidades da sociedade civil, para coibir a violência contra as mulheres acima de 18 anos que vivessem em situação de risco ou que eram vítimas de violência em Curitiba. A idade das mulheres referida no início do protocolo ficou contraditória, uma vez que nas intervenções se falou em serviço de referência para realizar o atendimento para usuárias de 12 anos vítimas de violência.

$\mathrm{Na}$ justificativa do protocolo se afirmou que a violência contra a mulher era histórica e era uma das mais presentes na sociedade, sendo que no ambiente familiar se identificava a maioria das ocorrências e, por ser este um ambiente no qual os profissionais de saúde atuavam, buscava-se com o protocolo estabelecer o acolhimento da equipe de saúde para com estas mulheres, como também, estabelecer fluxos no sentido de auxiliar na realização de atendimentos e encaminhamentos no setor saúde. Estabeleceram-se, ainda, fluxos com os setores citados acima e a responsabilidade/atribuição de cada serviço no atendimento.

Como violência contra a mulher registrou-se que seriam todos os fatos que continham desde a agressão verbal à agressão física com lesões evidentes e considerou-se, ainda, que os serviços de saúde pudessem auxiliar na identificação deste fenômeno no domicílio. Esta possibilidade de identificação precoce era porque as mulheres vítimas de violência os procuravam com queixas diversas e muitas vezes não verbalizavam a violência em si. Portanto, fazia-se necessário o protocolo para estabelecer orientação aos profissionais para identificar sinais que lhes permitissem realizar o diagnóstico e as intervenções preconizadas.

Foram padronizados os procedimentos nas consultas de enfermagem e médica, assim como os fluxos que os profissionais deveriam seguir para cada diagnóstico. Na consulta de enfermagem foi referido o uso da CIPESC $®$ como uma ferramenta a ser utilizada. Por fim, apresentou-se a ficha de notificação obrigatória e orientações para o seu preenchimento nos casos de violência contra a mulher e qual era o fluxo desta nos serviços de saúde. Ficou claro que independente da complexidade do serviço, assim como de sua natureza, público ou privado, todos deveriam encaminhar a informação para o Centro de Vigilância Epidemiológica da Secretaria de Saúde do Município. 
continuação

Quadro 2 - Análise do discurso nos protocolos vigentes na Secretaria Municipal de Saúde - CuritibaPR - 2009

\begin{abstract}
Documento:
Protocolo de emergências e urgências em obstetrícia nas maternidades vinculadas ao programa Mãe Curitibana. Secretaria Municipal de Saúde, Curitiba, 2004b

Interpretação:

Justificado pelos índices de mortalidade materna e infantil o protocolo teve a finalidade de organizar a atenção de emergência e urgência obstétricas nas oito maternidades conveniadas ao Programa Mãe Curitibana e Programa Nascer em Curitiba. Entre essas instituições encontravam-se hospitais públicos, privados e de ensino. Foi apontado o conceito de mortalidade materna como sendo "óbito de mulher durante a gestação ou dentro de 42 dias do término da gestação", que norteou as ações propostas no protocolo. Outras questões registradas foram para que fossem desenvolvidas ações de educação permanente para os profissionais que atuavam nos serviços que compunham este nível da atenção; ações para promover a melhoria das condições sociais e de educação da população em geral e ações que atendessem os indivíduos na sua integralidade em parceria com outros setores. Estes aspectos da assistência foram considerados como determinantes para a mudança dos dados epidemiológicos que apresentavam índices de mortalidade materna e infantil acima dos aceitáveis pela OMS. Na sequência foram apresentadas as doenças mais frequentes em situações de emergências e urgências na gestação, as características clínicas das doenças, indicação de exames de apoio diagnóstico a serem utilizados, critérios para o desenvolvimento de intervenções com a gestante e o feto e fluxo de encaminhamento dos usuários para atendimentos que garantissem intervenções resolutivas.
\end{abstract}

\title{
Documento:
}

Hipertensão - protocolo de atenção à Hipertensão Arterial Sistêmica. Secretaria Municipal de Saúde. Curitiba, 2004c.

Interpretação:

$\mathrm{Na}$ justificativa do protocolo foi registrada a necessidade de intervenção para reverter a alta prevalência da doença na população adulta. Outras questões seriam o modo de vida dos usuários hipertensos para possibilitar uma expectativa de vida mais longa com mudanças no modo de vida, consumo de dieta adequada, adesão à atividades físicas e diminuição do estresse. Referiu-se, ainda, que condições sensíveis à intervenção poderiam ser revertida. Estas eram favoráveis ao aparecimento da doença e a intervenção poderia ser desenvolvida pelos profissionais do serviço local de saúde, assim como por pessoas da comunidade. Para tal se propôs o desenvolvimento de atividades de educação à saúde que estimulem mudanças de hábitos de vida, atendimento clínico, atividades físicas e de lazer. Destacou-se que a inovação apontada foi o desenvolvimento da gestão da patologia e de casos para se controlar a doença e prevenir suas complicações clínicas. Para dar conta da proposta se estabeleceram-se parâmetros clínicos de avaliação, indicadores de riscos para complicações, tratamentos medicamentosos, encaminhamentos para outros níveis de complexidade da atenção à saúde, organização do trabalho, programas educativos, programas de atividades físicas e fluxos nos atendimentos.

Documento:

AIDS - atendimento inicial ao portador do HIV na unidade básica de saúde. 2. ${ }^{a}$ Ed Secretaria Municipal de Saúde, Curitiba, 2007c.

Interpretação:

$\mathrm{Na}$ justificativa para revisão da padronização de condutas foi apontada a prevalência da infecção pelo HIVIAIDS, assim como as dinâmicas das famílias, comunidades, portadores do HIVIAIDS e serviços de saúde da atenção básica no enfrentamento desta questão. Desde o primeiro protocolo o objetivo da Secretaria Municipal de Saúde foi organizar os atendimentos nas unidades de saúde para os portadores do HIV e para usuários que solicitassem apoio diagnóstico para o HIV. Para o diagnóstico precoce se propôs atividades desde o aconselhamento para a prevenção da infecção, bem como, o acolhimento e a assistência integral ao portador do HIV para se interromper a cadeia de transmissão. Outra questão importante foi sobre as orientações para os profissionais no sentido de que os indivíduos portadores do HIV fossem orientados para o autocuidado e a adesão ao tratamento para terem suas vidas com mais qualidade. 
continuação

Quadro 2 - Análise do discurso nos protocolos vigentes na Secretaria Municipal de Saúde - CuritibaPR - 2009

Os objetivos específicos apontados foram: retardar a progressão da imunodeficiência, evitar infecções oportunistas, diagnosticar e tratar precocemente as complicações da imunodeficiência e evitar o sofrimento físico e mental do portador. Portanto, as condutas estabelecidas foram para: a) testagem sorológica anti-HIV na qual se apontou condutas em teste positivo, negativo e indeterminado. Nas condutas indicadas para atuar junto aos menores de 18 anos com resultados positivos foram apresentadas diferentes estratégias diante da situação. Para estes casos destacou-se que se deveria investigar e considerar se o sujeito estaria preparado para o enfrentamento da questão ou se haveria necessidade de envolver a família para o acompanhamento e tratamento. Outra questão importante foi que ao se discutir o caso deveria ser considerada a decisão da equipe multiprofissional envolvida; b) avaliação clínica e laboratorial, foram apresentadas condutas ante situações clínicas e de resultados laboratoriais com ênfase em orientações para se evitar a transmissão do HIV; c) critérios para encaminhamento ao serviço de referência; d) recomendações para profilaxia de infecções oportunistas. e) recomendações para tratamento antiretroviral para indivíduo adolescente ou adulto; f) notificação compulsória dos casos em que, segundo o documento, as condutas referidas eram baseadas nas normatizações do Ministério da Saúde para o enfrentamento do agravo na população.

\section{Documento:}

Alfabetizando com saúde: temas para alfabetização de adultos, volume II. Secretaria Municipal de Saúde, Curitiba, 2006d.

Interpretação:

O material que foi analisado era uma apostila do programa, sendo este uma parceria entre as Secretarias Municipais de Saúde e de Educação. A proposta apresentada era de alfabetizar adultos munícipes de Curitiba com conteúdos que lhes permitisse refletir sobre a promoção da saúde. Os conteúdos apresentados se relacionavam a regulamentações do SUS; mudanças características do ciclo de vida; doenças crônicas; meio ambiente; uso de medicamentos entre outros temas relevantes para a população-alvo (adultos).

\section{Documento:}

Fisioterapia. Secretaria Municipal de Saúde, Curitiba, 2004d.

Interpretação:

O manual apresentou as atividades do fisioterapeuta da rede municipal de saúde, nos Distritos Sanitários, junto aos serviços da rede básica de atenção à saúde: UBS e US-PSF. Esclareceu sobre as intervenções desenvolvidas por esses profissionais junto aos usuários e como elas poderiam promover a vida com qualidade e prevenir adoecimentos. Na apresentação se justificou a necessidade de contratação dos profissionais, assim como as intervenções que desenvolvidas no sentido se ter um envelhecimento saudável na população e a necessidade de prevenção de doenças crônicas características do grupo populacional referido. Além da proposta que atenderia o grupo de idosos, no manual foram apresentadas intervenções para diferentes grupos populacionais, bem como os fluxos a serem seguidos de acordo com cada diagnóstico.

\section{Documento analisado:}

Protocolo de atenção à Hanseníase em Curitiba. Secretaria Municipal de Saúde, Curitiba, data desconhecida.

\section{Interpretação:}

Foi apontado como objetivo deste protocolo o apoio técnico aos profissionais de saúde para a assistência aos usuários hansenianos, assim como a definição do fluxo a ser seguido pelos profissionais da rede de serviços integrados de saúde no município e na região metropolitana. Foi estabelecida a competência de cada um dos serviços perante o caso. Na sequência definiram-se condutas para o diagnóstico, tratamento e procedimentos de vigilância epidemiológica ante os casos confirmados da doença. 
continuação

Quadro 2 - Análise do discurso nos protocolos vigentes na Secretaria Municipal de Saúde - CuritibaPR - 2009

Documento:

Acidentes loxocélicos: protocolo técnico e fluxo de atenção em Curitiba. Secretaria Municipal de Saúde, Curitiba, 2006e.

Interpretação:

O protocolo foi justificado pelos dados epidemiológicos que referem o número de acidentes com a aranha loxocélis em Curitiba. Foi registrada a necessidade de se organizar os serviços de saúde para diagnosticarem, intervirem e realizarem as atividades relativas à vigilância epidemiológica com precocidade e resolutividade. Neste sentido o conteúdo foi elaborado para que os profissionais de saúde soubessem reconhecer a aranha loxocélis por meio de suas características físicas, assim como a ferida no indivíduo que é resultante da picada. O protocolo tratou também de caracterizar o diagnóstico diferencial, o quadro clínico, o tratamento, ficha de notificação, fluxos e competências dos serviços e, por fim, as atividades de educação com orientações a serem desenvolvidas junto às comunidades e usuários.

\section{Documento:}

Memento terapêutico da farmácia curitibana. Secretaria Municipal de Saúde, Curitiba, 2005e.

Interpretação:

Segundo o documento analisado o objetivo para a implantação do protocolo foi garantir para os usuários do SUS o acesso aos fármacos, auxiliar o uso racional dos medicamentos na farmácia curitibana, assim como apoiar a equipe multiprofissional nas intervenções que são desenvolvidas na rede de serviços de saúde do município.

\section{Documento:}

Protocolo integrado: saúde mental em Curitiba. Secretaria Municipal de Saúde, Curitiba, 2002b.

Interpretação:

Os objetivos apresentados no protocolo foram que este orientaria os profissionais da rede de serviços de saúde de Curitiba sobre os cuidados em saúde mental e, consequentemente, melhoraria a assistência aos usuários. Além disso, afirmou-se que as mudanças ocorridas no processo de trabalho e organização dos serviços de saúde municipais levaram à realização desta versão que atualizava a versão elaborada em 1999. Outra finalidade para a atualização era que esta versão atenderia às normatizações da Reforma Psiquiátrica, na qual as propostas de atenção à saúde mental previam a desospitalização e o atendimento aos usuários portadores de transtornos mentais em unidades ambulatoriais mais próximas de suas residências ou em hospital dia. Para a continuidade das orientações padronizaram-se: ações preventivas de saúde mental; fluxos de atendimentos nos serviços e procedimentos a serem realizados de acordo com a competência de cada um; conceituação de doenças mentais e os direitos do cidadão portador de transtornos mentais.

\section{Documento:}

Cartilha do paciente em terapia nutricional enteral domiciliar. Curitiba, saúde levada a sério. Secretaria Municipal de Saúde, Curitiba, 2007d.

Interpretação:

O documento justifica que a proposta da cartilha era orientar o usuário que faz uso de sonda enteral e permanece em seu domicílio. Portanto, o conteúdo era dirigido também para o cuidador responsável pela elaboração e manipulação da alimentação e higiene do usuário.

Assim, as orientações foram elaboradas em uma linguagem acessível para a população e as explicações foram desde o que é uma alimentação enteral, a necessidade de se proceder a este tipo de alimentação, bem como quais eram os cuidados necessários para a elaboração de uma alimentação caseira e na manipulação de uma alimentação industrializada no domicílio. Outras orientações foram sobre os cuidados com a higiene das sondas e com a observação de sinais e sintomas que indicam complicações no quadro clínico do paciente. Como era uma cartilha para orientação ao usuário e familiar foram deixados espaços para anotações com o objetivo de que posteriormente pudessem ser discutidas com o nutricionista. 
continuação

Quadro 2 - Análise do discurso nos protocolos vigentes na Secretaria Municipal de Saúde - CuritibaPR - 2009

\author{
Documento: \\ Protocolo Integrado de Atenção à Saúde Bucal. Secretaria Municipal de Saúde, Curitiba, 2004e. \\ Interpretação:
}

No documento foi encontrada referência a fatores sociais dos usuários ou famílias que viviam em situações de risco para a saúde bucal e demais questões de saúde. A promoção da saúde referida foi vinculada ao autocuidado ou a adoção de estilo de vida mais saudável. Grande parte do documento foi direcionada para condutas clínicas ante determinados grupos populacionais e agravos mais comuns em determinadas faixas etárias. Não houve referência sobre as condições de vida das pessoas como determinação dos agravos odontológicos. As questões relacionadas aos agravos da saúde bucal foram apontadas como condições do sujeito - dimensão singular - mais especificamente aos aspectos clínicos dos agravos.

\title{
Documento:
}

Manual de Fluoterapia. Secretaria Municipal de Saúde, Curitiba, $2006 f$.

\section{Interpretação:}

No documento analisado se afirmou que o manual foi proposto para revisar e atualizar a padronização de fluoterapia nas Unidades de Saúde do Município. Este procedimento já era desenvolvido para a prevenção e controle da cárie dentária, das doenças periodentais e, ainda, para prevenir os efeitos adversos no uso abusivo do flúor (fluorose). A necessidade de se orientar o usuário para o autocuidado para a promoção da saúde bucal foi uma entre outras questões destacadas. As intervenções propostas eram tanto para indivíduos como para grupos prioritários, no caso atendidos por meio de ações coletivas.

\section{Documento:}

Manual de controle de infecção. Secretaria Municipal da saúde, Comissão de Garantia de Qualidade. Secretaria Municipal de Saúde, Curitiba, 2000b.

\section{Interpretação:}

Os objetivos das orientações contidas no manual eram de estabelecer normas para técnicas de limpeza, desinfecção e esterilização e, assim, institucionalizar o programa de controle de infecção ambulatorial para a rede de serviço da Secretaria Municipal e Saúde. Foi referido no documento que as normatizações seguiam as propostas do Ministério da Saúde.

\section{Documento:}

Manual de Práticas de Enfermagem. Secretaria Municipal da Saúde. Curitiba, 1999b.

\section{Interpretação:}

No manual se afirma que ele foi elaborado por profissionais de enfermagem de todos os níveis da Secretaria de Saúde e que a base para a definição dos termos foi a Classificação Internacional das Práticas de enfermagem (CIPE). O objetivo apontado foi que a enfermagem deveria se adequar às novas práticas e ao modelo assistencial vigente na SMS com vistas à integralidade do cuidado e excelência do serviço para implantar a função delegada ante os problemas de saúde dos usuários. Nesse sentido, propunham-se normas e procedimentos que viabilizassem: identificar as atividades de responsabilidade de cada profissional da equipe de enfermagem; roteiro para avaliação do estado de saúde dos usuários; os termos segundo a CIPE para proceder à avaliação do usuário e, por fim, abordagem de patologias por meio das queixas mais frequentes com fluxogramas a serem seguidos. 
conclusão

Quadro 2 - Análise do discurso nos protocolos vigentes na Secretaria Municipal de Saúde - CuritibaPR - 2009

\begin{abstract}
Documento:
Imunizações - cartilha de orientações técnicas para a atualização de equipes de enfermagem. 3. ${ }^{a}$ Ed. Secretaria Municipal de Saúde, Curitiba, $2008 f$.

Interpretação:

O manual estabeleceu orientações técnicas para imunização segundo o Programa Nacional de Imunizações (PNI) e referiu que a efetividade do programa - queda nos índices de morbidade e mortalidade por doenças imunopreveníveis - estava além da garantia de imunobiológicos eficazes e gratuitos para a população na rede básica de saúde. Afirmou que era necessário o desenvolvimento de um processo cuidadosamente acompanhado que deveria considerar desde o treinamento dos profissionais envolvidos para garantir qualidade na rede de frio, das técnicas de administração de vacinas, padronização do esquema vacinal para cada imunobiológico segundo a idade do usuário ou outras situações, padronização de contraindicações, caracterização e condutas para as reações pósvacinais, condutas diante de situações especiais, rotina de movimento mensal de imunobiológicos, gerenciamento de resíduos na sala de vacinas, padronização de procedimentos para controle de infecção, organização do setor e padronização de registros.
\end{abstract}

\title{
Documento:
}

Como ajudar o seu paciente a parar de fumar: protocolo de orientações para o profissional de saúde na abordagem mínina do fumante. Secretaria Municipal de Saúde, Curitiba, 2007e.

\section{Interpretação:}

O protocolo foi baseado no Programa Nacional de Controle do Tabagismo. E a justificativa foi pelo compromisso da gestão do município para a elaboração e implantação de Políticas Públicas para a promoção da saúde e prevenção de doenças. O tabagismo foi compreendido como uma dependência química em um inquérito realizado pelo Ministério da Saúde. Segundo o estudo, Curitiba foi a capital com a maior incidência de fumantes entre as 26 capitais pesquisadas. $O$ objetivo do programa era para o incentivo ao abandono do fumo pelos usuários dependentes do fumo e para desenvolver orientações preventivas para adolescentes e jovens no sentido de não iniciarem o hábito e consequentemente a dependência. Os dados epidemiológicos apontados como necessários de serem revertidos foram os índices de doenças cardiovasculares e de cânceres.

A intervenção proposta foi para a equipe multiprofissional com o compromisso de se deixar claro para o usuário as consequências de seu hábito e, assim, promover apoio em todos os momentos do processo relativo ao tratamento. $O$ tratamento estava baseado no eixo de abordagem cognitiva comportamental e com auxílio de medicamentos próprios em abordagem mais intensiva. Para o desenvolvimento de uma intervenção mais incisiva foi referida a necessidade da avaliação clínica prévia.

Nota: Os protocolos estão disponíveis em: http://sitesms.curitiba.pr.gov.br/saude/. Citados em: 2009 fev.

\subsection{O DISCURSO DO ENFERMEIRO PARA RECONHECER E ENFRENTAR AS NECESSIDADES EM SAÚDE DAS FAMÍLIAS COM OS RECURSOS DISPONIVEIS}

\section{Os resultados relacionados aos discursos das enfermeiras foram} organizados e apresentados nos quadros a seguir. Para a elaboração foram analisados os discursos de vinte e cinco entrevistadas. A entrevista foi individual 
no local de trabalho e durou por volta de trinta minutos. Todos os encontros foram agendados previamente. $O$ horário foi escolhido pela entrevistada segundo a sua rotina de trabalho com o objetivo de respeitar o ritmo de trabalho em cada realidade. As entrevistadas eram lotadas em quatorze unidades de saúde, sendo que destas três tinham a Estratégia Saúde da Família (US-ESF) implantada e as outras onze eram Unidades Básicas de Saúde (UBS).

No processo de análise as entrevistas foram transcritas e agrupadas por Unidade de Saúde. Posteriormente todas as entrevistas foram agrupadas por pergunta. Nesta etapa identificaram-se as temáticas emergentes no discurso. Após essa identificação foram agrupados os núcleos de sentido representativos de cada uma das temáticas. Com esta fase elaborada, os subtemas foram identificados após exaustiva leitura e em cada uma das temáticas reagruparam-se os núcleos de sentido na nova organização. Assim, constituiu-se a análise final conforme está apresentado nos quadros a seguir.

Para garantir que não houvesse a possibilidade de identificação dos sujeitos a opção que se teve foi retirar a identificação dos discursos deixando os núcleos de sentido agrupados como um único discurso em cada subtema. A decisão foi tomada após as leituras dos materiais elaborados nas diferentes etapas da análise. No processo se percebeu que havia evidências e especificidade das realidades nos relatos, o que permitiria a identificação dos sujeitos a qualquer momento, como já descrito no capítulo de metodologia.

Para a definição dos cinco temas tomaram-se as questões que foram norteadoras das entrevistas. Portanto, os temas são: como reconhece necessidades em saúde de uma família; as necessidades reconhecidas; intervenções para enfrentar as necessidades reconhecidas; recursos para desenvolver intervenções em situações nas quais foram reconhecidas necessidades em saúde. E como já referido anteriormente após esta definição foram elaborados os subtemas que ficaram constituídos conforme segue abaixo.

- No tema "como reconhece necessidades em saúde de uma família" foram identificados quatro subtemas - aproximação com a realidade das famílias e usuários para reconhecer necessidades em saúde; desenvolver atividades programáticas para reconhecer necessidades em saúde das famílias; processo de trabalho na Unidade de Saúde 
para reconhecer necessidades em saúde das famílias e articulação com as instituições locais para reconhecer necessidades em saúde das famílias.

- No tema as necessidades reconhecidas foram identificados quatro subtemas - as necessidades em saúde nos usuários; as necessidades em saúde nas famílias; as necessidades em saúde nas comunidades e as necessidades em saúde nas demandas nas Unidades de Saúde.

- No tema intervenções para enfrentar as necessidades reconhecidas foram identificados nove subtemas - intervenções desenvolvidas nas unidades de saúde; intervenções no domicílio; intervenções segundo o modelo de atenção à saúde; intervenções para promoção da saúde e prevenção de doenças; intervenções articuladas com outros setores e serviços de saúde de outros níveis de complexidade; intervenções desenvolvidas em equipe; capacitação da equipe para intervir; intervenções com a mobilização da comunidade, família e usuários, e intervenção com a participação da família.

- No tema "recursos para desenvolver intervenções em situações nas quais foram reconhecidas necessidades em saúde" foram identificados sete subtemas - os recursos disponíveis na Unidade de Saúde para planejar e desenvolver intervenções; recursos de outros serviços de saúde para o desenvolvimento de intervenções; articulação com instituições, técnicos e programas de outros setores como recursos para a intervenção; recursos comunitários para a intervenção; recursos da família e dos usuários para o desenvolvimento da intervenção; recursos da enfermeira para o desenvolvimento de intervenções em saúde e dificuldades de recursos para o desenvolvimento da intervenção. 
Quadro 3 - Núcleos de sentido do discurso das enfermeiras sobre como reconhecem necessidades em saúde das famílias moradoras nas áreas de abrangências sob suas responsabilidades agrupados segundo subtema - Curitiba-PR - 2009

\begin{tabular}{|c|c|}
\hline \multicolumn{2}{|c|}{$\begin{array}{l}\text { Tema: } \\
\text { Como reconhece necessidades em saúde de uma família }\end{array}$} \\
\hline Núcleos de sentido & Interpretação \\
\hline $\begin{array}{l}{[. . .] \text { na visita domiciliar [...] observar a higiene }} \\
\text { do usuário e de sua casa [...] Conhecendo } \\
\text { todas as famílias da área de abrangência [...] } \\
\text { a dinâmica da família frente às necessidades } \\
\text { em saúde [...] reconhecendo o papel dos } \\
\text { membros das familias [...] reconhecendo } \\
\text { como a família se insere na comunidade [...] } \\
\text { Pelo relato de ocorrências na área trazido } \\
\text { pelo agente comunitário [...] pelos problemas } \\
\text { que os agentes comunitários trazem [...] Pela } \\
\text { questão social da família [...] conhecendo a } \\
\text { realidade das pessoas em suas casas [...] } \\
\text { Avaliando a familia como um todo [...] na } \\
\text { família com muitos filhos [...] na visita na } \\
\text { comunidade [...] Visitas na área [...] }\end{array}$ & $\begin{array}{l}\text { Subtema: } \\
\text { Aproximação com a realidade das famílias e } \\
\text { usuários para reconhecer necessidades em } \\
\text { saúde } \\
\text { O domicílio foi citado como o ambiente que permite } \\
\text { ao enfermeiro ver a realidade do usuário e de sua } \\
\text { família diante das necessidades em saúde. E também } \\
\text { foi referido como um ambiente que revela a } \\
\text { determinação destas. As condições de higiene } \\
\text { pessoal, do domicílio e da comunidade foram citadas } \\
\text { como parâmetros para o reconhecimento das } \\
\text { necessidades em saúde. Perceber e compreender a } \\
\text { dinâmica da família no enfrentamento ao agravo ou } \\
\text { situação nova foi citado como algo que permite } \\
\text { reconhecer necessidades em saúde das famílias, } \\
\text { assim como conhecerem a comunidade, as famílias } \\
\text { moradoras do território e a relação que essas famílias } \\
\text { têm com a sua realidade. A família com muitos filhos } \\
\text { foi referida como expressão de necessidades em } \\
\text { saúde. Os entrevistados afirmaram que reconhecem } \\
\text { as necessidades em saúde dos usuários pelo olhar } \\
\text { do agente comunitário de saúde sobre a realidade } \\
\text { da comunidade, pois este profissional está presente } \\
\text { naquele cotidiano, diferentemente do próprio } \\
\text { enfermeiro, que na maioria das vezes, se detém na } \\
\text { rotina interna da Unidade de Saúde. As questões } \\
\text { sociais foram referidas como algo abrangente, } \\
\text { distante, específico de uma família. }\end{array}$ \\
\hline $\begin{array}{l}{[. . .] \text { anamnese [...] No exame físico [...] }} \\
\text { genograma [...] levantamento das condições } \\
\text { socioeconômicas das familias [...] Pela } \\
\text { demanda espontânea na Unidade de Saúde } \\
{[\ldots] \text { visitas domiciliares realizadas pelos agentes }} \\
\text { comunitários de saúde e auxiliares de } \\
\text { enfermagem [...] Pelos instrumentos existentes } \\
\text { na Unidade de Saúde [...] demanda de } \\
\text { usuários via telefone [...] dinâmicas de } \\
\text { grupos [...] Na consulta de enfermagem para } \\
\text { os indivíduos que participam dos programas } \\
\text { de saúde [...] monitoramento pelos programas } \\
\text { da mulher, criança e adolescente [...] na } \\
\text { consulta de enfermagem a necessidade é vista } \\
\text { como individual e não familiar [...] no adulto } \\
\text { hipertenso [...] na gravidez na adolescência } \\
{[. . .] \text { relatórios dos programas [...] identificando a }} \\
\text { dinâmica familiar frente às mudanças no ciclo } \\
\text { de vida e novos membros [...] identificando } \\
\text { as familias mais carentes ou com riscos de } \\
\text { saúde [...]. }\end{array}$ & $\begin{array}{l}\text { Subtema: } \\
\text { Desenvolver atividades programáticas para } \\
\text { reconhecer necessidades em saúde das famílias } \\
\text { As atividades programáticas, seja no atendimento } \\
\text { individual, seja no familiar, foram referidas como } \\
\text { potencializadoras do reconhecimento das necessidades } \\
\text { em saúde, para tal o enfermeiro referiu que utilizava os } \\
\text { instrumentos, as atividades e os relatórios estabelecidos } \\
\text { pelos programas de saúde. Os entrevistados citaram } \\
\text { ainda que as aproximações com os usuários, objetos } \\
\text { das ações programáticas, Ihes permitem reconhecer } \\
\text { necessidades em saúde. Os critérios, as ferramentas e } \\
\text { os instrumentos, estabelecidos pela Estratégia Saúde } \\
\text { da Família, para reconhecer o território e as famílias } \\
\text { moradoras da área, possibilitaram ao enfermeiro } \\
\text { reconhecer necessidades em saúde. As atividades } \\
\text { programáticas realizadas no domicílio pelos agentes } \\
\text { comunitários de saúde e auxiliares de enfermagem, bem } \\
\text { como demandas espontâneas para os atendimentos } \\
\text { e as intervenções realizadas na Unidade de Saúde, } \\
\text { permitiam o reconhecimento de necessidades em } \\
\text { saúde. }\end{array}$ \\
\hline
\end{tabular}


Quadro 3 - Núcleos de sentido do discurso das enfermeiras sobre como reconhecem necessidades em saúde das famílias moradoras nas áreas de abrangências sob suas responsabilidades agrupados segundo subtema - Curitiba-PR - 2009

\begin{tabular}{|c|c|}
\hline \multicolumn{2}{|c|}{$\begin{array}{l}\text { Tema: } \\
\text { Como reconhece necessidades em saúde de uma família }\end{array}$} \\
\hline Núcleos de sentido & Interpretação \\
\hline $\begin{array}{l}\text { [...] conversa com outros profissionais [...] no } \\
\text { multirão na Unidade de Saúde [...] }\end{array}$ & $\begin{array}{l}\text { Subtema: } \\
\text { Processo de trabalho na Unidade de Saúde para } \\
\text { reconhecer necessidades em saúde das famílias } \\
\text { A interação da equipe de saúde e o trabalho coletivo } \\
\text { na Unidade de Saúde permitiram ao enfermeiro } \\
\text { reconhecer as necessidades em saúde dos usuários. }\end{array}$ \\
\hline $\begin{array}{l}\text { [...] pelo desenvolvimento de atividades junto } \\
\text { às instituições da comunidade [...] rede de } \\
\text { proteção à criança [...] demandas trazidas } \\
\text { por outras instituições locais [...] demandas } \\
\text { trazidas pela associação de moradores [...] }\end{array}$ & $\begin{array}{l}\text { Subtema: } \\
\text { Articulação com as instituições locais para } \\
\text { reconhecer necessidades em saúde das famílias } \\
\text { As demandas trazidas por instituições, assim como } \\
\text { o trabalho articulado com outros órgãos, setores e } \\
\text { comunidade permitiram ao enfermeiro reconhecer as } \\
\text { necessidades em saúde. }\end{array}$ \\
\hline
\end{tabular}

Fonte: Dados da entrevista com os sujeitos da pesquisa 
Quadro 4 - Núcleos de sentido do discurso das enfermeiras sobre as necessidades em saúde reconhecidas nas famílias moradoras nas áreas de abrangências sob suas responsabilidades agrupados segundo subtema - Curitiba-PR - 2009

\begin{tabular}{|l|l|}
\hline \multicolumn{2}{|c|}{ As necessidad } \\
\hline \multicolumn{2}{|c|}{ Núcleos de sentido } \\
\hline
\end{tabular}

[...] falta de informação [...] violência física [...] violência verbal [...] falta de autocuidado [...] baixa auto-estima [...] carência emocional [...] higiene pessoal (falta) autocuidado deficiente [...] falta de dinheiro [...] falta de qualificação para o mercado de trabalho [...] falta de roupas adequadas [...] fome [...] má alimentação [...] portadores de transtornos mentais por uso de drogas [...] problemas de saúde mental [...] doenças psiquiátricas [...] depressão, transtomos de humor [...] drogadição, alcoolismos [...] drogadito alcoolista [...] tabagismo [...] doenças crônicas [...] hipertensão hipertenso alcoolista [...] hipertensão no adulto jovem [...] úlceras varicosas [...] diabetes [...] feridas em pés de portadores de diabetes [...] amputação de membro [...] pacientes acamados [...] úlceras de pressão [...] portadores de seqüelas de AVC e derrame acamados [...] tuberculose [...] pediculose [...] escabiose [...] verminose [...] doenças infecto-contagiosas [...] portadores de HIV [...] portadores de HIV grávidas [...] gestantes de risco [...] gravidez de risco [...] alteração no exame de preventivo [...] neoplasias [...] câncer [...] feridas póscirurgicas [...] os idosos [...] idosos com deficiências físicas [...] os adolescentes [...] as adolescentes grávidas [...] drogadição na adolescência [...] adolescentes usuários de drogas [...] crianças com diarréia [...] crianças com problemas de comportamento [...] usuários com necessidades de atendimentos domiciliares [...] hidratação venosa [...] oxigênio para portadores de dificuldades respiratórias [...] usuários de medicações específicas (alto custo) [...] curativos [...] falta de adesão ao tratamento de hipertensão [...] não adesão ao tratamento de HIVIAIDS [...]
Tema:

lades reconhecidas

\section{Subtema:}

\section{As necessidades em saúde nos usuários}

As necessidades reconhecidas foram extraídas de situações relatadas.

Assim, estas foram, predominantemente, sobre situações e agravos expressos na dimensão singular, apesar de as entrevistadas referirem processos relacionados à dimensão particular e estrutural, tais como: trabalho, renda, educação e acesso a alimentos. No discurso se percebeu que a ênfase recaía na observação mais imediata desses processos por meio do reconhecimento de adoecimentos diagnosticados, assim como sinais, sintomas e queixas relacionados a eles. Alguns grupos populacionais foram mais apontados como portadores de necessidades: adolescentes, idosos, mulheres na fase de reprodução e crianças. Os agravos descritos foram: transtornos psiquiátricos: dependência química álcool, drogas não lícitas e tabagismo; doenças crônicas: hipertensão, hipertensão em adultos jovens, diabetes; doenças infecto-contagiosas - HIV, tuberculose, escabiose e verminose; portadores de dependências por sequelas das complicações de doenças crônicas; gestação de alto risco; neoplasias e suas complicações. As alterações de exames que indicam neoplasia também foram referidas como necessidades em saúde.

Os idosos, um dos grupos populacionais mais citados como portadores de necessidades em saúde, foi reconhecido pelas características do processo de envelhecimento, pois nesta fase da vida é comum o desenvolvimento de doenças crônicas degenerativas e estes foram os agravos mais descritos no grupo. Os adolescentes foram referidos como portadores de problemas de saúde a serem enfrentados, entre estes se destacam a drogadição e a gravidez. As crianças, como portadoras de problemas de comportamentos e de diarréias. No caso dos problemas de comportamento as referências foram relativas às situações que a Rede de Proteção tem identificado para que se desenvolvam intervenções de prevenção em um trabalho interinstitucional. Outras necessidades referidas foram relativas aos usuários com demandas para atendimentos domiciliares. Os cuidados desenvolvidos nos domicílios eram para aqueles que não podiam se deslocar até a Unidade de Saúde. As referências foram desde a execução de curativo às demandas específicas com medicações endovenosas que necessitam de controle contínuo pela equipe de enfermagem. No tratamento dos agravos citados, os usuários que não aderiam a eles foram citados como portadores de necessidades, e o atendimento no domicílio foi referido como uma estratégia de enfrentamento, pois se buscava junto aos familiares constituir um grupo de apoio para tal. 
continuação

Quadro 4 - Núcleos de sentido do discurso das enfermeiras sobre as necessidades em saúde reconhecidas nas famílias moradoras nas áreas de abrangências sob suas responsabilidades agrupados segundo subtema - Curitiba-PR - 2009

\begin{tabular}{|c|c|}
\hline \multicolumn{2}{|c|}{$\begin{array}{c}\text { Tema: } \\
\text { As necessidades reconhecidas }\end{array}$} \\
\hline Núcleos de sentido & Interpretação \\
\hline & $\begin{array}{l}\text { Foram citados ainda como necessidades em saúde } \\
\text { dos indivíduos a falta de informação, a violência física e } \\
\text { verbal, a falta de autocuidado, a baixa autoestima, a } \\
\text { carência emocional, a falta de higiene pessoal, a falta } \\
\text { de dinheiro, a falta de roupas adequadas, a falta de } \\
\text { qualificação para o mercado de trabalho e a fome. } \\
\text { Estas foram referidas como uma questão do indivíduo } \\
\text { ou relacionada a um grupo com características } \\
\text { próprias que estava presente no território. }\end{array}$ \\
\hline $\begin{array}{l}\text { [...] cuidados com os filhos e pais [...] perdão } \\
\text { entre pais e filhos [...] organização da família } \\
\text { [...] relacionamento familiar [...] desrespon- } \\
\text { sabilização com os cuidados a serem } \\
\text { desenvolvidos com os membros da família - } \\
\text { pais e filhos [...] as mudanças no ciclo de } \\
\text { vida dos membros da família [...] a chegada } \\
\text { de novos membros na familia [...] conflitos } \\
\text { familiares [...] famílias carentes que migram } \\
\text { muito [...] condições sócio-econômicas das } \\
\text { familias [...] falta de acesso a alimentos [...] } \\
\text { falta de renda familiar [...] higiene nas casas } \\
\text { (a falta) [...] o portador de doença e a relação } \\
\text { com a familia [...] famílias desestruturadas } \\
\text { pelos problemas de saúde de um membro } \\
{[. . .] \text { cuidadores com dificuldades para atender à }} \\
\text { demanda do familiar [...] falta de um cuidador } \\
\text { no domicílio [...] desresponsabilização da } \\
\text { família para cuidar do paciente [...] filhos } \\
\text { drogaditos [...] criança em situação de risco } \\
\text { e abandono [...] crianças menores de um } \\
\text { ano [...] cuidados com o bebe [...] cuidados } \\
\text { com a amamentação [...] dificuldades para } \\
\text { amamentar [...] não adesão dos pais para a } \\
\text { campanha de vacina [...] idosos e doentes } \\
\text { abandonados pelas famílias [...] mulheres a } \\
\text { frente das famílias [...] famílias de mulheres } \\
\text { de várias gerações com os pais ausentes [...] } \\
\text { violência doméstica [...] }\end{array}$ & $\begin{array}{l}\text { Subtema: } \\
\text { As necessidades em saúde nas famílias } \\
\text { Ao falar de necessidades em saúde que reconheceram } \\
\text { e enfrentaram em situações junto às famílias, as } \\
\text { enfermeiras descreveram situações nas quais observaram } \\
\text { ausência de cuidados entre os membros dos grupos. } \\
\text { As dinâmicas dos relacionamentos no núcleo familiar } \\
\text { e a estrutura das famílias foram descritas como fatores } \\
\text { que poderiam proteger ou não a saúde. Nestes casos } \\
\text { foram referidas situações de desresponsabilização } \\
\text { dos familiares com seus dependentes e chamaram a } \\
\text { atenção para a relação e cuidados entre pais e filhos } \\
\text { como determinante de necessidades. A dinâmica } \\
\text { conflituosa na família foi mencionada como fator } \\
\text { desfavorável à saúde, seja quando se enfrenta um } \\
\text { adoecimento de um dos membros, seja quando } \\
\text { vivenciam mudança no ciclo de vida ou na chegada } \\
\text { dos novos membros. Os conflitos entre os membros } \\
\text { da família e destes com a equipe de saúde foram } \\
\text { lembrados quando se relatou situações de violência } \\
\text { nas famílias, pois as dificuldades e a falta de } \\
\text { suportes para enfrentar estas situações geraram } \\
\text { atitudes agressivas. A composição de famílias de } \\
\text { mulheres de diferentes gerações e seus filhos } \\
\text { também foi apontada como necessidade em saúde. } \\
\text { Quanto aos cuidados que os familiares deveriam ter } \\
\text { entre si, os entrevistados apontaram dificuldades } \\
\text { para que fossem desenvolvidos, pois não havia um } \\
\text { membro que assumisse o papel de cuidador no } \\
\text { domicílio e, ainda, casos nos quais não se tinham as } \\
\text { condições materiais para desenvolver o cuidado } \\
\text { necessário. Assim, a falta de renda, alimentação e } \\
\text { higiene foram referidas como fatores que } \\
\text { dificultaram o cuidado domiciliar. Os membros das } \\
\text { famílias que necessitavam de cuidados foram os } \\
\text { adolescentes, os idosos e as crianças. Estes últimos } \\
\text { por serem totalmente dependentes de cuidados dos } \\
\text { familiares e os adolescentes por serem aqueles que } \\
\text { necessitariam da autoridade e controle da família } \\
\text { para não se envolverem com drogas e violências } \\
\text { presentes nas comunidades. }\end{array}$ \\
\hline
\end{tabular}


Quadro 4 - Núcleos de sentido do discurso das enfermeiras sobre as necessidades em saúde reconhecidas nas famílias moradoras nas áreas de abrangências sob suas responsabilidades agrupados segundo subtema - Curitiba-PR - 2009

\begin{tabular}{|c|c|}
\hline \multicolumn{2}{|c|}{$\begin{array}{c}\text { Tema: } \\
\text { As necessidades reconhecidas }\end{array}$} \\
\hline Núcleos de sentido & Interpretação \\
\hline $\begin{array}{l}\text { [...] precárias condições de moradia [...] } \\
\text { desemprego [...] cães abandonados na rua } \\
\text { [...] mordedura de cães [...] resíduos pelo } \\
\text { bairro [...] moradores de área de ocupação } \\
\text { irregular [...] população de baixa renda e } \\
\text { baixa escolaridade [...] tráfico de drogas na } \\
\text { área de abrangência [...] problema de ordem } \\
\text { social [...] moradias irregulares [...] destinação } \\
\text { inadequada de lixo [...] familias sem renda } \\
{[\ldots] \text { não acesso a alimentos básicos [...] }} \\
\text { problemas sociais [...] violência e mulheres } \\
{[\ldots] \text { violência [...] assassinatos [...] crianças }} \\
\text { vitimizadas [...] crianças comunicantes de Tb } \\
{[\ldots] \text { falta de higiene [...] condições precárias }} \\
\text { de vida [...] áreas de risco no território [...] } \\
\text { falta de trabalho [...] moradia em condições } \\
\text { precárias [...] familias pobres [...] falta de } \\
\text { saneamento [...] diversidade de situações } \\
\text { pela diferenciação da população moradora } \\
\text { na área [...]. }\end{array}$ & $\begin{array}{l}\text { Subtema: } \\
\text { As necessidades em saúde nas comunidades } \\
\text { As situações nas quais reconheceram necessidades } \\
\text { em saúde na comunidade estão representadas pela } \\
\text { precariedade das condições de vida da população } \\
\text { local descritas em casos relatados. O não acesso ao } \\
\text { trabalho e consequentemente à renda, moradia e } \\
\text { alimentação foi referido como necessidade em } \\
\text { saúde. Outras questões apontadas foram: condições } \\
\text { de saneamento precárias, presença de animais nas ruas } \\
\text { sem controle, destinação inadequada de lixo, ocupações } \\
\text { irregulares de terrenos, baixa escolaridade, tráfico } \\
\text { de drogas, violência, portadores e comunicantes } \\
\text { de doenças transmissíveis e, ainda, a diversidade } \\
\text { econômica e social observada na ocupação do território. } \\
\text { As condições que determinavam as situações encon- } \\
\text { tradas foram referidas na dimensão particular, logo } \\
\text { na própria comunidade. Os discursos apontaram a } \\
\text { realidade local como se esta fosse autônoma e típica } \\
\text { da periferia de uma cidade grande. }\end{array}$ \\
\hline $\begin{array}{l}{[. . .] \text { demandas para ações curativistas [...] }} \\
\text { demandas para consultas médicas [...] } \\
\text { demandas para consultas de especialistas } \\
\text { [...] encaminhamentos para serviços de alta } \\
\text { complexidade [...] falta de acesso aos exames } \\
\text { complementares e consultas nos especialistas } \\
\text { por falta de renda [...] transporte para os } \\
\text { usuários irem a outros serviços de saúde [...] } \\
\text { pouca adesão ao programa de prevenção do } \\
\text { câncer ginecológico [...] baixa cobertura de } \\
\text { preventivo do câncer [...] baixa cobertura } \\
\text { vacinal [...] usuários da região metropolitana [...] }\end{array}$ & $\begin{array}{l}\text { Subtema: } \\
\text { As necessidades em saúde nas demandas nas } \\
\text { Unidades de Saúde } \\
\text { Ao referirem sobre as necessidades reconhecidas e } \\
\text { enfrentadas nas Unidades de Saúde, as enfermeiras } \\
\text { descreveram situações nas quais encontravam } \\
\text { demanda para ações e atividades programáticas. } \\
\text { Destacaram que a busca se dava pelas ações curativas } \\
\text { e principalmente por consultas médicas nos diversos } \\
\text { níveis de complexidade da rede de serviços. O uso } \\
\text { dos serviços especializados referidos seria pelos } \\
\text { encaminhamentos médicos, uma vez que as } \\
\text { entrevistadas atuavam nos serviços de atenção } \\
\text { básica. Contraditoriamente se observa no discurso } \\
\text { do profissional do Sistema Público de Saúde referência } \\
\text { à falta de renda para consumir serviços especializados } \\
\text { e de apoio diagnóstico como necessidade em saúde. } \\
\text { Nas regulamentações do Sistema Único de Saúde } \\
\text { estes serviços são apontados como necessários para } \\
\text { promover a assistência integral à saúde e no caso } \\
\text { desses não existirem na rede pública deveriam ser } \\
\text { contratados para garantira o acesso aos usuários. Por } \\
\text { fim, a não adesão dos usuários às atividades de } \\
\text { prevenção também foi reconhecida como necessidade } \\
\text { em saúde. }\end{array}$ \\
\hline
\end{tabular}

Fonte: Dados da entrevista com os sujeitos da pesquisa 
Quadro 5 - Núcleos de sentido do discurso das enfermeiras sobre as intervenções promovidas para enfrentar necessidades em saúde das famílias moradoras nas áreas de abrangências sob suas responsabilidades agrupados segundo subtema - Curitiba-PR - 2009

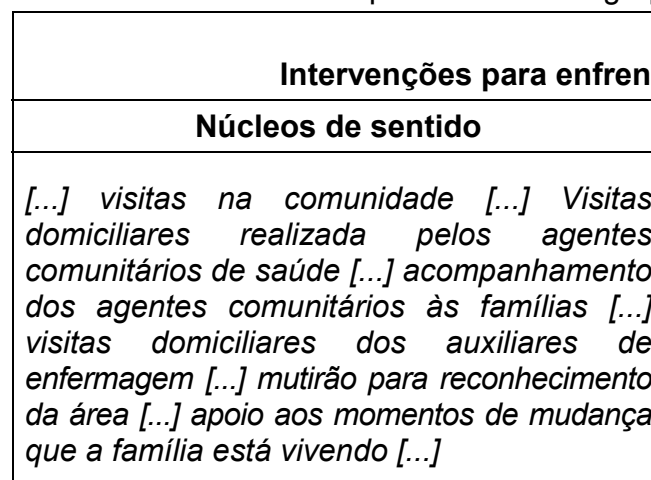

[...] atendimento à demanda espontânea [..] orientação de enfermagem na recepção para usuários de demanda espontânea, segundo queixas [...] Recepção e organização de demanda para consulta médica [...] organização à de encaminhamentos para especialistas segundo as prioridades [...] registros burocráticos dos encaminhamentos e agendamentos [...] registros nos prontuários [...] organização da equipe de enfermagem para acompanhamento de usuários que utilizam o transporte [...] relatórios [...] agendamento de consulta médica [...] sistema de notificação [...] Procedimentos administrativos para transportes para usuários que fazem uso de outros serviços de saúde [...] [...] agendamento de consultas com serviços especializados [...] exames de apoio diagnóstico $[. .$.$] consultas médicas [...]$ distribuição de medicamentos [...] distribuição de medicamentos controlados [...] Consultas [...] exames [...] Intervenção individual [...] coleta de exames no domicílio [...] entrega de medicamentos no domicílio [...] chamar serviço de urgências [...] chamar serviço de emergências [...]

[...] voluntariado para cuidados no domicílio [...] aciono o movimento de voluntários da comunidade para desenvolver cuidados aos acamados [...] interação com a comunidade [...] [...] lideranças locais [...] associação comunitária [...] apoio de moradores vizinhos e familiares com experiências nas situações a serem enfrentadas pelas famílias [...] Comitê de voluntários [...] voluntariado
Tema:

as necessidades reconhecidas

Interpretação

Subtema:

Conhecer a realidade do usuário para intervir

O conhecimento do local de moradia e das dinâmicas da vida familiar e comunitária foi citado como necessário para se compreender o agravo para se intervir, e percebe-se no discurso que esse conhecimento foi no sentido de constatar a realidade do usuário e da família para promover o apoio profissional no processo.

\section{Subtema:}

\section{Intervenção na Unidade de Saúde}

As intervenções desenvolvidas na Unidade de Saúde, citadas pelas enfermeiras, foram no sentido de atender à demanda espontânea na rotina por meio de procedimentos administrativos e terapêuticos, e nas falas observa-se a predominância do modelo curativista. As entrevistadas referiram que organizavam o serviço para atender às necessidades dos usuários, segundo a possibilidade de agendamento nas atividades e ações da equipe de saúde. As ações da equipe relatadas se concentraram em atividades do profissional médico, assim referenda a centralidade das intervenções no profissional. Não houve referência à lógica que norteava a demanda, ou seja, a vinda do usuário para a unidade em busca daquilo que estava sendo ofertado. Pode-se observar nos discursos que houve predominância de demandas para intervenções em agravos já instalados ou para apoio diagnóstico dos mesmos. A maioria das intervenções que foram desenvolvidas na Unidade de Saúde foi para atendimentos às demandas individuais e, assim, a intervenção era organizada para que se realizasse o procedimento na Unidade de Saúde e na impossibilidade de o usuário ir à Unidade o profissional se deslocava até os domicílios. Nos casos relatados eram profissionais de enfermagem e o Agente Comunitário de Saúde (ACS).

\section{Subtema:}

Intervenção com a mobilização da comunidade, família e usuários

A mobilização da comunidade, família e usuários foi citada como algo que poderia atender às demandas na falta de ações do Estado no setor. Nesse sentido, as entrevistadas apontaram que as lideranças comunitárias, a comunidade e as famílias eram possibilidades para viabilizar intervenções de enfrentamento a determinadas necessidades em saúde, principalmente quando a intervenção estava relacionada a suprir questões socioeconômicas dos usuários. O voluntariado foi referido como um potencial da comunidade no sentido de desenvolver intervenções para as quais a equipe já não dispunha de recursos, mas tinha disponibilidade para orientar e acompanhar. A mobilização foi citada como importante para atender às necessidades, tais como: alimentação, medicamentos, transporte e trabalho. 
continuação

Quadro 5 - Núcleos de sentido do discurso das enfermeiras sobre as intervenções promovidas para enfrentar necessidades em saúde das famílias moradoras nas áreas de abrangências sob suas responsabilidades agrupados segundo subtema - Curitiba-PR - 2009

\begin{tabular}{|c|c|}
\hline \multicolumn{2}{|c|}{$\begin{array}{c}\text { Tema: } \\
\text { Intervenções para enfrentar as necessidades reconhecidas }\end{array}$} \\
\hline Núcleos de sentido & Interpretação \\
\hline $\begin{array}{l}{[. . .] \text { modelo de intervenção diferente do PSF }} \\
{[. . .] \text { Intervir sem impor os valores pessoais }} \\
\text { do técnico [...] suporte para a familia [...] } \\
\text { programas de saúde [...] Busca de inativos } \\
\text { nos programas de saúde [...] olhar mais } \\
\text { atento às questões das doenças infecto- } \\
\text { contagiosas [...] preenchimento de cadastros } \\
\text { das famílias [...] desenvolve ações para } \\
\text { atender às questões sociais [...] preenchimento } \\
\text { de formulário para notificar violência doméstica } \\
\text { [...] distribuição de medicamentos para as } \\
\text { doenças infecto-contagiosas segundo dados da } \\
\text { vigilância epidemiológica [...] visitas domiciliares } \\
\text { para promover à adesão ao tratamento para } \\
\text { dependência química [...] levantamento de } \\
\text { inativos [...] busca ativa pelo agente } \\
\text { comunitário [...] responsabilização dos pais } \\
\text { para garantir renda alimentos e cuidados } \\
\text { para com os filhos [...] vigilância para } \\
\text { verificar o seguimento das orientações [...] } \\
\text { visita domiciliária programada [...] supervisão } \\
\text { das atividades desenvolvidas pela equipe e } \\
\text { pela familia [...] visitas domiciliares para } \\
\text { promover à adesão ao tratamento para } \\
\text { dependência química [...] mobilizar o usuário } \\
\text { para a adesão ao tratamento [...] }\end{array}$ & $\begin{array}{l}\text { Subtema: } \\
\text { Intervenção segundo o modelo de atenção à } \\
\text { saúde } \\
\text { Para as entrevistadas o desenvolvimento das } \\
\text { intervenções seguia os pressupostos e diretrizes dos } \\
\text { programas de saúde implantados na Unidade de } \\
\text { Saúde. Nas Unidades nas quais a ESF não estava } \\
\text { implantada, compararam-se as intervenções realizadas } \\
\text { com as diretrizes estabelecidas pela mesma. Neste } \\
\text { caso, a comparação era sobre as intervenções } \\
\text { preconizadas pela Estratégia Saúde da Família e as } \\
\text { intervenções preconizadas para uma Unidade } \\
\text { Básica de Saúde. Na perspectiva de atender ao } \\
\text { usuário, à família e à comunidade, os profissionais } \\
\text { referiram que era necessário ter a aproximação com a } \\
\text { realidade do usuário por meio de visitas domiciliárias, } \\
\text { descrição de território e identificação das condições } \\
\text { socioeconômicas mesmo sem a implantação da } \\
\text { ESF. Ao se aproximarem das famílias as entrevistadas } \\
\text { tinham a preocupação de não imporem seus valores } \\
\text { pessoais e técnicos. Referiram que ao estabelecer } \\
\text { as relações com a família procuravam discutir as } \\
\text { responsabilidades para o enfrentamento dos agravos, } \\
\text { principalmente quando era identificado algum grau } \\
\text { de dependência na relação entre pais e filhos - } \\
\text { crianças e adultos ou adultos e idosos. Para a } \\
\text { verificação do seguimento das orientações e prescrições } \\
\text { citaram que faziam vigilância e supervisão nos casos } \\
\text { para acompanhar o cumprimento ou não do que foi } \\
\text { orientado. O acompanhamento e a vigilância foram } \\
\text { apontados como uma ação direta ou indireta, esta } \\
\text { última quando a ação era delegada para o ACS. Em } \\
\text { casos em que delegavam a realização de uma } \\
\text { intervenção a um profissional da equipe, auxiliares de } \\
\text { enfermagem e ACS, disseram que faziam supervisão } \\
\text { para acompanhar o andamento da situação. Ficou } \\
\text { demonstrado que havia preocupação com a adesão } \\
\text { aos tratamentos prescritos e neste sentido havia a } \\
\text { necessidade de envolver usuários e famílias no processo. }\end{array}$ \\
\hline
\end{tabular}


continuação

Quadro 5 - Núcleos de sentido do discurso das enfermeiras sobre as intervenções promovidas para enfrentar necessidades em saúde das famílias moradoras nas áreas de abrangências sob suas responsabilidades agrupados segundo subtema - Curitiba-PR - 2009

\begin{tabular}{|l|}
\hline \multicolumn{2}{|c|}{ Intervenções para enfrenta } \\
\hline \multicolumn{2}{|c|}{ Núcleos de sentido } \\
\hline \\
[...] busca de relação de confiança entre familia \\
e equipe de saúde [...] relacionamento equipe \\
e usuário [...] planejamento de atividades com \\
a equipe [...] reunião mensal para planejamento \\
das ações [...] avaliações dos técnicos [...] \\
registro das intervenções e orientações para \\
posterior avaliação [...] mobiliza a equipe de \\
SF para as ações junto ao usuário [...] \\
[...] intervenção articulada com a psicologia \\
{$[\ldots .$.$] intervenções junto com a assistente$} \\
social [...] trabalha em parceria com outros \\
profissionais, instituições e usuários [...] dar \\
dinheiro ou vale transporte para usuários \\
que necessitam fazer exames ou consultas \\
com especialistas [...]
\end{tabular}

Tema:

ar as necessidades reconhecidas

Subtema:
Trabalhar em equipe para intervir

A integração entre os profissionais da equipe de saúde e usuário, assim como a participação dos envolvidos no planejamento, desenvolvimento, acompanhamento e na avaliação das ações de intervenção foram citados como importantes para se atingir os objetivos propostos no enfrentamento aos agravos e na promoção da saúde. A articulação entre os profissionais também foi citada no sentido potencializar o desenvolvimento de ações resolutivas. Atitudes como dar dinheiro ou vale transporte com o objetivo de garantir que 0 usuário seguisse aquilo que foi prescrito ou requisitado foram adotadas pelas entrevistadas que contaram com a colaboração da equipe local. No momento dos relatos as entrevistadas refletiram sobre a atitude adotada e ponderaram que não estavam agindo como queriam, mas pela escassez de recursos dos usuários e da instituição.

\section{Subtema:}

\section{Capacitar equipe para intervir}

[...] treinamento da equipe [...] treinamento e orientação da equipe para as intervenções [...] Dificuldades pessoais para intervir em demandas originadas por questões sócio-econômicas [...] orientação sobre as intervenções para o agente comunitário [...]

[...] orientar a família para reconhecer seus problemas [...] vínculos com as famílias [...] Parceria com as famílias para preparar um cuidador [...] busca na família um apoio para auxiliar a equipe na busca da adesão ao tratamento pelo usuário [...] busca de familiares para cuidar de doentes abandonados [...] orientar famílias para chamar serviços de urgências e emergências [...] responsabilizar os membros da família para enfrentar a questão [...]

A capacitação da equipe para a intervenção foi citada como necessária uma vez que se percebesse a necessidade de intervir diferentemente do modelo vigente - curativista e hospitalocêntrico. Ao demonstrar esta preocupação as entrevistadas referiram dificuldades pessoais para desenvolver intervenções que iriam além da dimensão biológica relacionada ao agravo a ser enfrentado. Assim, expressaram reflexões sobre as condições socioeconômicas do usuário, sobre o processo saúde-doença e sobre as limitações das intervenções que desenvolviam.

\section{Subtema:}

\section{Intervenção com a participação da família}

As entrevistadas afirmaram que havia a necessidade de parceria com a família para enfrentar as questões de saúde. Colocaram que a parceria era um meio de fazer com que os sujeitos reconhecessem seus problemas e auxiliassem a equipe a enfrentá-los com o desenvolvimento de cuidados no domićlio. Outro ponto era que a parceria também serviria para a família ajudar no convencimento de um de seus membros para a adesão ao tratamento. Não foram citadas referências quanto ao desenvolvimento da compreensão sobre a determinação dos agravos a serem enfrentados junto aos usuários; ao contrário, se afirmou que estes sujeitos deveriam se responsabilizar pelo enfrentamento de suas questões de saúde, assim como seus familiares também deveriam ser responsabilizados. 
continuação

Quadro 5 - Núcleos de sentido do discurso das enfermeiras sobre as intervenções promovidas para enfrentar necessidades em saúde das famílias moradoras nas áreas de abrangências sob suas responsabilidades agrupados segundo subtema - Curitiba-PR - 2009

\begin{tabular}{|c|c|}
\hline \multicolumn{2}{|c|}{$\begin{array}{c}\text { Tema: } \\
\text { Intervenções para enfrentar as necessidades reconhecidas }\end{array}$} \\
\hline Núcleos de sentido & Interpretação \\
\hline $\begin{array}{l}\text { [...] atividades de educação em saúde [...] } \\
\text { orientação de enfermagem [...] atendimento } \\
\text { diferenciado para população idosa [...] } \\
\text { orientação para familiares com portadores } \\
\text { de dependências e idosos [...] chamar a } \\
\text { vigilância sanitária para monitoramento das } \\
\text { condições de higiene ambiental do bairro [...] } \\
\text { orientações quanto à higiene da casa e } \\
\text { pessoal [...] palestras para dependentes } \\
\text { químicos [...] educação à saúde [...] Grupo } \\
\text { de apoio para dependência química [...] } \\
\text { Grupos para portadores de doenças crônicas } \\
\text { [...] passeios e caminhadas para portadores } \\
\text { de doenças crônicas [...] visitas domiciliares } \\
\text { para acompanhamento de crianças de risco } \\
{[\ldots] \text { reuniões dos membros da rede de }} \\
\text { proteção para discussão dos casos de crianças } \\
\text { em situações de risco [...] Busca ativa [...] } \\
\text { grupos para drogaditos e alcoolistas [...] } \\
\text { oficinas para gestantes [...] palestras sobre } \\
\text { métodos contraceptivos [...] trabalhos } \\
\text { educativos junto às escolas [...] consulta de } \\
\text { enfermagem no programa de pré-natal [...] } \\
\text { orientação para o auto-exame de mama [...] } \\
\text { busca de familias [...] grupos de grávidas } \\
\text { adolescentes [...] orientações [...] preventivos } \\
\text { de câncer [...] grupos educativos para } \\
\text { gestantes [...] palestras para as mulheres do } \\
\text { clube de mães [...] desenvolvimento de } \\
\text { grupos de convivência para a comunidade } \\
{[\ldots] \text { grupos de apoio desenvolvidos pela }} \\
\text { psicóloga [...] Orientar o paciente sobre o } \\
\text { seu problema [...] investigação quanto à } \\
\text { saúde física e mental frente à questão de } \\
\text { saúde a ser enfrentada [...] }\end{array}$ & $\begin{array}{l}\text { Subtema: } \\
\text { Intervenções para a promoção da saúde e } \\
\text { prevenção de doenças } \\
\text { As entrevistadas citaram o desenvolvimento de } \\
\text { intervenções por meio de atividades de educação à } \\
\text { saúde com o objetivo promover a saúde, tais como: } \\
\text { orientações, grupos, palestras, oficinas e visitas } \\
\text { domiciliares. Neste sentido, referiram que realizavam } \\
\text { atendimento diferenciado para grupos populacionais, } \\
\text { no caso: idosos, gestantes e crianças. A preocupação } \\
\text { com intervenções para combater a dependência } \\
\text { química, drogas e álcool foi significativa, e para } \\
\text { prevenir o agravo e acompanhar os dependentes as } \\
\text { entrevistadas referiram que desenvolviam grupos e } \\
\text { visitas domiciliares. O preparo para tais atividades } \\
\text { ocorria com as consultorias dos profissionais da área } \\
\text { da Saúde Mental dos serviços conveniados pela } \\
\text { Secretaria Municipal de Saúde com definição de } \\
\text { referência para cada Unidade de Saúde. Também } \\
\text { no sentido de promover a saúde na comunidade } \\
\text { disseram que realizavam monitoramento das condições } \\
\text { de higiene de casas e ruas e atuavam junto à rede } \\
\text { de proteção do menor e adolescente acompanhando } \\
\text { e discutindo casos de risco. Para a prevenção e } \\
\text { controle de adoecimentos foram apontadas intervenções } \\
\text { que tinham o objetivo de identificar famílias de riscos } \\
\text { por meio de busca ativa de portadores de doenças } \\
\text { crônicas e infecto-contagiosas, consultas de enfermagem, } \\
\text { orientações para o autoexame de mama e realização } \\
\text { de coleta de material para o preventivo de câncer de } \\
\text { colo de útero. }\end{array}$ \\
\hline $\begin{array}{l}{[. . .] \text { rede de proteção para a criança [...] }} \\
\text { programa estadual do leite [...] bolsa familia } \\
{[. . .] \text { serviço social [...] programa de }} \\
\text { alimentação suplementar do município com } \\
\text { a nutricionista do DS [...] encaminhamentos } \\
\text { para cursos de qualificação profissional [...] } \\
\text { encaminhamento para empregos ofertados } \\
\text { no mercado [...] consultoria de técnico da } \\
\text { saúde mental [...] encaminhamentos para } \\
\text { CAPS e Hospital Dia [...] ação } \\
\text { interinstitucional no combate à dependência } \\
\text { química [...] Internamentos para } \\
\text { dependência química [...] encaminhar para } \\
\text { psicologia [...] encaminhamento para } \\
\text { psiquiatria [...] encaminhamento para o } \\
\text { CEMUM (24 horas) [...] encaminhamento } \\
\text { para serviço de internação para drogaditos } \\
{[. . .] \text { acionar o conselho tutelar [...] acionar a }}\end{array}$ & $\begin{array}{l}\text { Subtema: } \\
\text { Intervenções articuladas com outros setores e } \\
\text { serviços de saúde de outros níveis de } \\
\text { complexidade }\end{array}$ \\
\hline
\end{tabular}


Quadro 5 - Núcleos de sentido do discurso das enfermeiras sobre as intervenções promovidas para enfrentar necessidades em saúde das famílias moradoras nas áreas de abrangências sob suas responsabilidades agrupados segundo subtema - Curitiba-PR - 2009

\begin{tabular}{|c|c|}
\hline \multicolumn{2}{|c|}{$\begin{array}{c}\text { Tema: } \\
\text { Intervenções para enfrentar as necessidades reconhecidas }\end{array}$} \\
\hline Núcleos de sentido & Interpretação \\
\hline $\begin{array}{l}\text { guarda - mirim [...] acionar a creche [...] } \\
\text { acionar a igreja [...] recursos do Distrito [...] } \\
\text { contatos com outros níveis do sistema para } \\
\text { agilizar o atendimento de transporte de } \\
\text { usuários [...] busca de crianças fora da } \\
\text { escola [...] cestas básicas para familias sem } \\
\text { renda [...] conselhos [...] intercede para } \\
\text { agilizar exames de apoio diagnóstico [...] } \\
\text { encaminha para acesso à bolsa família [...] }\end{array}$ & $\begin{array}{l}\text { Estas articulações diminuiriam o sofrimento dos } \\
\text { usuários por promover acesso a programas sociais } \\
\text { que lhes garantiriam alimentos, cuidados, trabalho e } \\
\text { renda. }\end{array}$ \\
\hline $\begin{array}{l}{[. . .] \text { Consulta de enfermagem no domicílio }} \\
{[. . .] \text { avaliação de enfermagem no domicílio }} \\
\text { [...] orientações de enfermagem no domicílio } \\
{[. . .] \text { cuidados de enfermagem no domicilio }} \\
\text { [...] orientar para adesão ao tratamento [...] } \\
\text { hidratação venosa no domicilio [...] curativos } \\
\text { especiais para feridas extensas [...] cuidados } \\
\text { de enfermagem para pacientes terminais [...] } \\
\text { orientações para cuidados com feridas no } \\
\text { domicílio [...] acompanhamento dos } \\
\text { resultados de exames [...]. }\end{array}$ & $\begin{array}{l}\text { Subtema: } \\
\text { Intervenções no domicílio } \\
\text { As entrevistadas referiram que a maioria das intervenções } \\
\text { que realizavam nos domicílios era curativa para } \\
\text { usuários acamados e dependentes, mesmo quando } \\
\text { as Unidades de Saúde não tinham a ESF implantada. } \\
\text { Em alguns casos havia necessidade de materiais } \\
\text { específicos e para consegui-los a enfermeira os } \\
\text { buscava junto a SMS, DS e outras instituições que } \\
\text { os disponibilizavam. }\end{array}$ \\
\hline
\end{tabular}

Fonte: Dados da entrevista com os sujeitos da pesquisa 
Quadro 6 - Núcleos de sentido do discurso das enfermeiras sobre os recursos para reconhecer e enfrentar as necessidades em saúde das famílias moradoras nas áreas de abrangências sob suas responsabilidades agrupados segundo subtema - Curitiba-PR - 2009

Tema:
Recursos para desenvolver intervenções em situações nas quais foram reconhecidas necessidades em saúde

\begin{tabular}{|c|c|}
\hline Núcleos de sentido & Interpretação \\
\hline $\begin{array}{l}{[. .] \text { A equipe }[. .] \text { Equipe multiprofissional }} \\
\text { local [...] médicos [...] dentistas [...] auxiliares }\end{array}$ & $\begin{array}{l}\text { Subtema: } \\
\text { Os recursos disponíveis na Unidade de Saúde } \\
\text { para planejar e desenvolver intervenções }\end{array}$ \\
\hline
\end{tabular}

de enfermagem [...] agentes comunitários de saúde [...] $A$ equipe de enfermagem, a equipe da odonto [...] apoio e relacionamento entre os técnicos na Unidade de Saúde [...] reunião de equipe para discutir a questão de saúde do usuário e as intervenções a serem desenvolvidas [...] reunião dos enfermeiros para discutir a questão de saúde do usuário $e$ as intervenções a serem desenvolvidas [...] reunião com a autoridade sanitária para organização das intervenções a serem desenvolvidas e rotina do serviço [...] equipamentos locais [...] Telefone [...] Recursos da Unidade de Saúde [...] estrutura física da Unidade de Saúde em fase de adequação [...] programas de saúde [...] programa mãe curitibana [...] divulgação de atividades com recursos locais [...] convites feitos nas visitas domiciliares dos agentes comunitários [...] palestras de alto nível [...] preservativos [...] anticoncepcional oral, injetável, injetável trimestral, injetável mensal, tem o DIU [...] Oficinas de gestantes $[\ldots]$ grupo de dança $[. .$.

[...] serviços de saúde de alta complexidade [...] sistema de referência e contra-referência [...] técnicos de saúde do Distrito Sanitário [...] Consultas de especialistas [...] apoio da coordenação do Distrito Sanitário para priorizar agendamentos muito longos [...] apoio de técnicos do Distrito Sanitário para o desenvolvimento de intervenções [...] fisioterapeuta [...] técnicos de serviços credenciados para o desenvolvimento de ações em saúde mental [...] SAMU [...] materiais para curativos especiais [...] suplementação nutricional [...] farmácia [...] vacinas [...] psicotrópicos [...] programa de acesso a medicamentos de alto custo e especiais [...] rede de serviços para encaminhamentos [...] Centro de Atendimento Psicossocial (CAPS) [...] Hospital Dia [...] exames de apoio para controle de doenças crônicas [...] Distrito Sanitário [...] secretaria Municipal de Saúde [...] Suporte dos técnicos do Hospital de Clínicas [...] serviços credenciados ao SUS [...] Hospitais [...] serviços de referência [...]
Como recurso para o desenvolvimento das intervenções as entrevistadas referiram à equipe de saúde local ou citaram os profissionais que a compunham. Citaram também a importância da dinâmica de relacionamento e a participação dos profissionais na definição e no acompanhamento das intervenções. A gestão local foi citada como um recurso com o qual as entrevistadas poderiam contar, fosse para definir uma intervenção diferenciada ou para garantir a rotina do serviço. Os equipamentos locais foram muito citados e as entrevistadas referiram desde a linha telefônica até equipamentos técnicos específicos para a intervenção em saúde, assim como falaram da estrutura física disponível para o desenvolvimento das atividades. Os níveis gerenciais do Distrito Sanitário e da Secretaria Municipal de Saúde foram referidos como recursos que possibilitavam o desenvolvimento da intervenção em saúde na Unidade. Outra questão foi que os programas ou atividades programáticas foram citados como recursos para o desenvolvimento de atividades que seriam de promoção da saúde e de prevenção de doenças para grupos populacionais específicos. Neste último caso, a referência foi devido aos insumos que são previstos para os atendimentos previamente estabelecidos para os usuários cadastrados.

\section{Subtema:}

Recursos de outros serviços de saúde para o desenvolvimento de intervenções

Ao referir sobre os recursos que são disponibilizados por outros Serviços Públicos de Saúde e serviços credenciados ao sistema com diferentes níveis de complexidade tecnológica para a assistência, as entrevistadas identificaram os apoios recebidos de técnicos destas instituições, assim como recursos que lhes foram disponibilizados para a intervenção que desenvolveram na unidade para usuários portadores de doença mental, doenças crônicas, urgências clínicas e emergências. Também citaram como recursos o acesso a insumos para ações específicas, no caso, curativos especiais, fármacos e vacinas. Os Programas de Saúde para atendimento a usuários em serviços de alta complexidade foram citados como recursos, pois nestes estão previstos acesso a determinados recursos e, assim, permitiam 0 atendimento às demandas específicas de grupos ou usuários. 
continuação

Quadro 6 - Núcleos de sentido do discurso das enfermeiras sobre os recursos para reconhecer e enfrentar as necessidades em saúde das famílias moradoras nas áreas de abrangências sob suas responsabilidades agrupados segundo subtema - Curitiba-PR - 2009

\begin{tabular}{|c|c|}
\hline \multicolumn{2}{|c|}{$\begin{array}{l}\text { Tema: } \\
\text { Recursos para desenvolver intervenções em situações nas quais foram reconhecidas } \\
\text { necessidades em saúde }\end{array}$} \\
\hline Núcleos de sentido & Interpretação \\
\hline 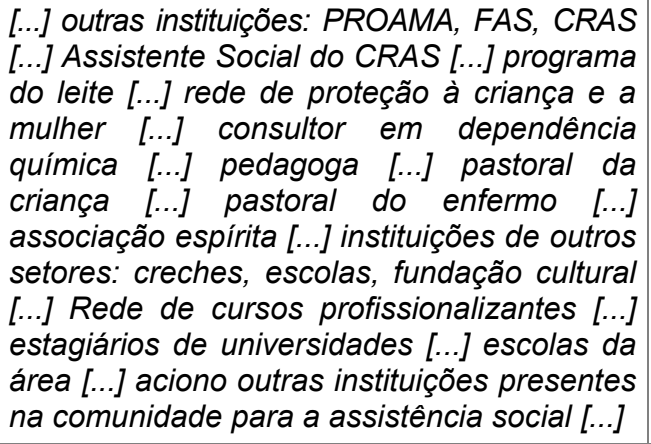 & 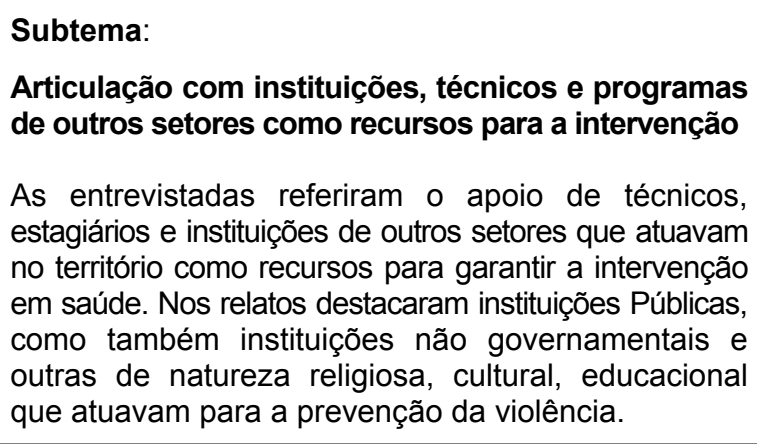 \\
\hline $\begin{array}{l}\text { [...] Recursos comunitários [...] Verba arrecadada } \\
\text { no bazar de doações realizado na comunidade } \\
\text { [...] auxílio da comunidade de maneira geral } \\
\text { [...] horta comunitária [...] Mobilizo recursos } \\
\text { locais [...] recursos de políticos locais [...] } \\
\text { Mobilização da comunidade para levantar } \\
\text { recursos [...] voluntariado para ajudar em } \\
\text { questões sociais [...] bazar para arrecadação } \\
\text { de verbas de apoio aos necessitados da } \\
\text { comunidade [...] }\end{array}$ & $\begin{array}{l}\text { Subtema: } \\
\text { Recursos comunitários para a intervenção } \\
\text { Os recursos comunitários, assim como o movimento } \\
\text { social organizado e o voluntariado foram reconhecidos } \\
\text { como potencial para o desenvolvimento de intervenções } \\
\text { em saúde. }\end{array}$ \\
\hline $\begin{array}{l}\text { [...] recursos financeiros do usuário para } \\
\text { aquisição de medicamentos [...] compreensão } \\
\text { sobre como funciona o complexo sistema } \\
\text { burocrático do setor saúde [...] a familia [...] } \\
\text { recursos dos domicílios dos próprios } \\
\text { usuários [...] }\end{array}$ & $\begin{array}{l}\text { Subtema: } \\
\text { Recursos da família e dos usuários para o desen- } \\
\text { volvimento da intervenção } \\
\text { As entrevistadas referiram que alguns recursos } \\
\text { utilizados na intervenção são do próprio usuário. Entre } \\
\text { os recursos citados, apontam-se desde recurso } \\
\text { financeiro para a aquisição de medicamentos até as } \\
\text { condições de moradia que possibilitam ou inviabilizavam } \\
\text { o desenvolvimento do cuidado no ambiente domiciliar. } \\
\text { A disponibilidade dos familiares e a capacidade } \\
\text { intelectual dos envolvidos permitiriam que os usuários } \\
\text { compreendessem a complexidade burocrática do } \\
\text { setor saúde em diferentes intervenções. }\end{array}$ \\
\hline $\begin{array}{l}{[. . .] \text { conhecimentos pessoais para a orientação }} \\
\text { verbal [...] competências pessoais do enfermeiro } \\
\text { para avaliar os casos [...] competência } \\
\text { do enfermeiro em ter as informações e } \\
\text { transformá-las naquilo que necessita o usuário } \\
{[\ldots]} \\
{[\ldots] \text { Criatividade para usar os recursos }} \\
\text { segundo as possibilidades dos usuários [...] }\end{array}$ & $\begin{array}{l}\text { Subtema: } \\
\text { Recursos da enfermeira para o desenvolvimento } \\
\text { de intervenções em saúde } \\
\text { Foi apontado pelas entrevistadas o uso dos recursos } \\
\text { pessoais para seus desempenhos nas intervenções de } \\
\text { enfrentamento às necessidades em saúde reconhecidas. } \\
\text { As entrevistadas falaram sobre a capacidade que } \\
\text { tinham para mobilizar e desenvolver determinadas } \\
\text { habilidades, assim como de usar a fundamentação } \\
\text { teórica da formação, no planejamento e desenvolvimento } \\
\text { de intervenção. Destacaram ainda o uso da criatividade } \\
\text { para um desempenho satisfatório. }\end{array}$ \\
\hline
\end{tabular}


conclusão

Quadro 6 - Núcleos de sentido do discurso das enfermeiras sobre os recursos para reconhecer e enfrentar as necessidades em saúde das famílias moradoras nas áreas de abrangências sob suas responsabilidades agrupados segundo subtema - Curitiba-PR - 2009

\begin{tabular}{|c|c|}
\hline \multicolumn{2}{|c|}{$\begin{array}{l}\text { Tema: } \\
\text { Recursos para desenvolver intervenções em situações nas quais foram reconhecidas } \\
\text { necessidades em saúde }\end{array}$} \\
\hline Núcleos de sentido & Interpretação \\
\hline $\begin{array}{l}\text { [...] Falta de espaço físico para a consulta de } \\
\text { enfermagem [...] dificuldade de transporte } \\
\text { de paciente [...] falta equipamentos para } \\
\text { atendimento do enfermeiro ao paciente [...] } \\
\text { espaço físico inadequado para os atendimentos } \\
\text { da Unidade de Saúde [...] faltam auxiliares de } \\
\text { enfermagem [...] faltam agentes comunitários } \\
\text { de saúde [...] }\end{array}$ & $\begin{array}{l}\text { Subtema: } \\
\text { Dificuldades de recursos para o desenvolvimento } \\
\text { da intervenção } \\
\text { As entrevistadas afirmaram falta de pessoal, de } \\
\text { recursos físicos e de materiais para o desenvolvimento } \\
\text { de intervenções na Unidade de Saúde, assim como } \\
\text { também afirmaram a falta de acesso a recursos } \\
\text { de apoio para transporte de usuários para serviços } \\
\text { de referência. }\end{array}$ \\
\hline
\end{tabular}

Fonte: Dados da entrevista com os sujeitos da pesquisa 


\section{DISCUSSÃO}

O presente capítulo apresenta a discussão sobre o conjunto de resultados anteriormente descritos à luz das categorias analíticas. Este processo teve início a partir da delimitação do objeto estudado, quando as reflexões começaram a ser gestadas. Nesta caminhada procurou-se explorar dados sobre as condições de vida e de saúde da população moradora do Distrito Sanitário Boa Vista, Curitiba, Paraná, nas dimensões da realidade: estrutural, particular e singular com os dados secundários para caracterização do território municipal e distrital, os discursos das Conferências Municipais de Saúde nos últimos dez anos (1997-2007), os discursos dos Protocolos de Saúde vigentes na SMS-Curitiba e também em dados dos discursos dos sujeitos da pesquisa.

$\mathrm{Na}$ sistematização e organização do relatório as reflexões foram aprofundadas e o conhecimento foi sendo construído em partes, sem que se perdesse a visão da totalidade. Portanto, o presente capítulo é a síntese da reflexão referida que tem a competência avaliativa do enfermeiro para reconhecer e enfrentar necessidades em saúde das famílias moradoras do Distrito Boa Vista como objeto a ser compreendido. Acredita-se que com esta caminhada não se esgotam as possibilidades de construções de conhecimentos sobre este objeto, pois como refere Konder (1981, p.37):

[...] A realidade é sempre mais rica do que o conhecimento que a gente tem dela. Há sempre algo que escapa às nossas sínteses; isso, porém, não nos dispensa do esforço de elaborar sínteses; se quisermos entender melhor a nossa realidade. A síntese é a visão do conjunto que permite ao homem descobrir a estrutura significativa da realidade com que se defronta, numa situação dada. E é essa estrutura significativa - que a visão de conjunto proporciona - que é chamada de totalidade (grifo do autor). 


\subsection{O RECONHECIMENTO DAS NECESSIDADES EM SAÚDE}

O reconhecimento das necessidades em saúde das famílias para as entrevistadas está relacionado à aproximação com as realidades das famílias e usuários, ao desenvolvimento de atividades programáticas, ao processo de trabalho na Unidade de Saúde e à articulação com as instituições locais.

A aproximação às realidades de saúde dos usuários e das famílias descritas nas entrevistas era principalmente no desenvolvimento de visitas domiciliárias e visitas às comunidades das áreas de abrangência da Unidade de Saúde. As observações realizadas eram sobre as condições de higiene pessoal e do ambiente, sobre a dinâmica da família diante de um agravo ou a uma situação nova que o grupo estaria vivendo. $\mathrm{O}$ agente comunitário foi reconhecido como o profissional que realizava constantemente visitas domiciliárias e visitas nas comunidades, o enfermeiro como o profissional que cumpria rotina de atividades na própria Unidade de Saúde e, consequentemente, a realização de atividades externas se tornava mais difícil. Nesse sentido, as entrevistadas reconheceram que por meio dos relatos de atividades dos agentes comunitários era possível conhecer as realidades dos usuários e das famílias.

Para Cowley e Houston (2004), o "encontro" entre os conhecimentos, científico e a realidade social, na visita domiciliária, norteados por critérios baseados em referencial teórico que propicie o uso de ferramentas para a compreensão dos determinantes da realidade e levantamento das necessidades em saúde, permite ao profissional compreender a realidade dos sujeitos para propor intervenção em saúde efetivas. Nakamura et al. (2009) apontam o uso de instrumentos que possibilita o reconhecimento das necessidades em saúde, assim como as vulnerabilidades sociais orientam o profissional de saúde para a prática em saúde coletiva.

Nos discursos foi referido que conhecer as questões sociais das famílias serviria para identificar necessidades em saúde. Porém, a compreensão sobre o 'social' apontada é como se este fosse um dos polos de uma realidade. No primeiro polo está o 'social' referente à realidade objetiva, em 
dados concretos no cotidiano dos sujeitos, tal como a inserção no processo de produção, as condições da moradia, o consumo de bens e produtos, as relações entre os membros da família e da família com a comunidade. No segundo polo está o 'social' não concreto, não palpável, algo não específico e abrangente, distante do cotidiano das famílias, mas determinante da realidade objetiva. Logo, compreende-se que as entrevistadas se referem às dimensões da realidade. No polo do concreto encontra-se a dimensão singular e no polo do não concreto, as dimensões particular e estrutural, pois estas estão relacionadas a processos que não são observados facilmente no território da Unidade de Saúde.

Outra questão que se pode afirmar sobre a compreensão sobre o 'social' se refere às intervenções sobre este: ao ser percebido como polos diferentes na mesma realidade as descrições de intervenção demonstraram que a tendência para intervir recaiu sobre o polo concreto. Isto porque, para modificar a realidade objetiva encontrada, as entrevistadas descreveram que atuaram sobre as condições precárias da vida das famílias promovendo o encaminhamento para suprir a ausência de alguma coisa, pela própria emergência da situação. Assim, para reverter a situação, identificaram-se o fator determinante mais evidente na realidade e os recursos disponíveis que permitiam agir para modificá-lo. A contradição é que ao mesmo tempo em que houve percepção sobre dimensões não concretas, a intervenção descrita ocorreu sem se refletir sobre os processos determinantes daquela situação. Porque, ao apontarem que questões econômicas e políticas estavam relacionadas à situação descrita (polo não concreto da realidade), em seguida reafirmaram condições de risco para o desenvolvimento de agravos presentes no modo de viver das famílias e destacaram o estilo de vida dos sujeitos como determinantes do processo saúde-doença.

Ficaram evidentes as limitações para o desenvolvimento de intervenções, uma vez que as próprias condições dadas para o trabalho na saúde não permitiam ir além, ao contrário, referendavam ações que atendiam imediatamente ao carecimento e à realização de orientações para que os indivíduos promovessem mudanças nas suas realidades por meio de escolhas pessoais para uma vida com qualidade e saúde. Para tal, poderiam ter a ajuda 
de programas assistenciais desenvolvidos na comunidade. Os programas assistenciais citados eram promovidos por instituições públicas, não governamentais ou religiosas.

Para Breilh (2006) e Barata (2005), compreender a realidade objetiva como determinação social do processo saúde-doença, sem explorar as dimensões que conformam o fenômeno observado, é seguir a linha do pensamento positivista. Esta lógica de pensamento não permite explorar a historicidade, articulação e hierarquização dos processos que determinam a realidade concreta. Cowley, Mitcheson e Houston (2004) descrevem o fenômeno da medicalização da visita domiciliária pelos visitadores de saúde na Inglaterra e afirmam que estes, ao não utilizarem instrumentos previamente elaborados, segundo referencial teórico apropriado para reconhecerem as necessidades em saúde, identificam apenas fatores de riscos para agravos segundo critério e referenciais epidemiológicos.

No pensamento liberal, os processos de determinação são negados e o esforço individual é a base para permitir aos indivíduos a mobilidade social. Assim, se descompromete a sociedade com a luta por políticas sociais mais justas no sentido de transformar a realidade indesejada (Barata, 2006). As normatizações das práticas dos serviços de saúde têm como enfoque diminuir os riscos de adoecimentos que estão identificados em dados epidemiológicos e, nesta lógica, se estabelecem previamente as necessidades em saúde a serem reconhecidas e atendidas nas atividades programáticas (Stotz, 1991).

A caracterização de Curitiba e Distrito Sanitário Boa Vista, no capítulo de resultados, descreve dimensões da realidade deste território que está muito além daquilo que se pode observar em um domicílio. No espaço domiciliário não há possibilidade de se encontrar as relações estabelecidas na produção que determinam a reprodução social dos grupos e famílias, assim como não é possível reconhecer a historicidade dos processos de desgastes e fortalecimentos destes sujeitos. Laurell (1983) afirma que a historicidade do processo saúde-doença é expressa por estudos sobre o desgaste do indivíduo pela sua inserção na produção, em determinada sociedade em um determinado tempo, e os casos clínicos individuais não permitem explorar esta compreensão. 
Heller (1986) afirma que as necessidades consideradas existenciais, naturais ou necessárias atendem à manutenção da vida dos indivíduos em uma determinada sociedade em um tempo histórico. Para terem a satisfação das suas necessidades, os sujeitos que pertencem a uma determinada classe social em uma sociedade capitalista dependem da inserção na produção, no trabalho. Compreender a realidade imediata possibilita ver se as necessidades necessárias estão sendo atendidas. Ampliar esta compreensão para além do domicílio é buscar informações que permitam refletir sobre os processos determinantes nas diferentes dimensões da realidade.

O desenvolvimento de atividades programáticas para as entrevistadas potencializava o reconhecimento das necessidades em saúde. O programa mais referido foi a Estratégia Saúde da Família (ESF) pelas atividades e ações preconizadas por ela. Nas unidades de saúde das entrevistadas três tinham a ESF implantada e onze não tinham a ESF implantada, eram Unidades Básicas de Saúde (UBS). Nestas últimas também houve referências às diretrizes da ESF como possibilidade para se reconhecer as necessidades em saúde. Essa referência ocorreu porque as entrevistadas admitiram como potencialidade da estratégia um de seus pressupostos para a intervenção aproximação da equipe de saúde com a realidade das famílias para o reconhecimento das necessidades em saúde.

Outra potencialidade dos programas implantados para reconhecer as necessidades em saúde, segundo as entrevistadas, estava na elaboração dos registros e relatórios que realizavam periodicamente. Nesse caso, acredita-se que ao elaborarem os relatórios e registros os profissionais refletiam sobre os dados consolidados e por meio destes reconheciam outra dimensão da realidade na qual estavam atuando. A referência à outra dimensão da realidade é porque as entrevistadas referiram que a aproximação com os usuários inscritos nos programas lhes permitia reconhecer necessidades em saúde. Logo, o reconhecimento destas estava vinculado à realidade dos usuários inscritos nos programas. Estes sujeitos são representantes de parte da populaçãoalvo da área de abrangência do serviço local de saúde, pois as suas inserções na ação programática estão vinculadas ao adoecimento ou à característica específica do ciclo de vida, entre outros critérios que atendem às diretrizes 
estabelecidas nos programas. Assim, a realidade que acreditavam poder compreender, nesta perspectiva, era na verdade parte de um todo que não estava sendo percebido e necessidade em saúde se confundia com o critério do programa.

As demandas espontâneas para os atendimentos e intervenções realizadas na Unidade de Saúde possibilitavam o reconhecimento de necessidades em saúde, segundo as entrevistadas. Esta compreensão reforça a análise acima, pois a mesma ocorre pela lógica da programação que organiza o quê fazer nos serviços para uma população-alvo específica e previamente estabelecida. Nesta mesma lógica os indivíduos se dirigem aos serviços de saúde, pois se organizam para buscar aquilo que sabem ser possível conseguir e resolver em cada um dos serviços de saúde disponíveis no território. Portanto, a 'demanda espontânea' passa a ser muito mais pela possibilidade de acesso do que pela necessidade em saúde sentida pelo indivíduo. Quando estão cientes de que o serviço não permite o acesso ou desenvolve ações com baixa resolutividade para alguma questão, os sujeitos, à sua maneira, redirecionam suas demandas para outro local, seja em serviços institucionalizados ou em práticas de saúde não oficiais, tais como: benzedeiras, garrafadas, rezas em grupos religiosos, orientações de familiares e conhecidos para uso de produtos que Ihes aliviem o sintoma.

A lógica que estabelece a demanda para os serviços de saúde está distante das necessidades em saúde do usuário, pois, como afirma Stotz (1991), nem todas as necessidades sentidas pelo indivíduo serão atendidas pelo serviço que tem previamente determinadas as ações que ali serão desenvolvidas e quais serão as necessidades a serem atendidas. Segundo Mendes (1999); Egry (1996) e Mendes-Gonçalves (1992), para se efetivar uma nova forma de intervir e atender às necessidades em saúde, faz-se necessário refletir sobre a realidade encontrada, assim como sobre sua determinação. A construção de uma nova proposta de intervenção deve ser dada com a participação dos técnicos e dos usuários ou seus representantes.

As ações programáticas realizadas por outros profissionais nos domicílios dos usuários, neste caso foram citados os agentes comunitários de saúde e os auxiliares de enfermagem, permitiriam que as entrevistadas também 
reconhecessem necessidades em saúde. Esta referência é convergente com outras já analisadas nas quais se identificou que os relatos de atividades do ACS Ihes permitiriam reconhecer as necessidades em saúde, assim reafirmaram suas dificuldades em participar de atividades externas à Unidade de Saúde e demonstraram que a supervisão sobre os trabalhos dos profissionais sob sua responsabilidade técnica Ihes possibilitava compreender indiretamente a realidade dos usuários, assim como suas necessidades em saúde.

Conforme já apontado anteriormente, as ações que têm como base a epidemiologia para identificar os riscos para o desenvolvimento de agravos à saúde não possibilita o reconhecimento das necessidades em saúde. Esta prática no SUS tem sido utilizada para garantir o aumento da cobertura, a ampliação do acesso e o planejamento de programas. Assim, como referendam Sala (1993), Schraiber (1993) e Ayres (1995b), esta lógica toma o indivíduo pela expressão coletiva do adoecimento e não pela necessidade em saúde experimentada individualmente.

O reconhecimento de necessidades em saúde por meio do relato de outro profissional torna-se possível quando a equipe de saúde fundamenta suas ações em referencial teórico previamente estabelecido e discutido por todos e, ainda, quando existe clareza sobre a organização do trabalho, o uso de ferramentas para a intervenção. Caso contrário, compreender a realidade por meio do relato da avaliação realizada por outro profissional pode referendar as concepções de risco para a saúde segundo as normatizações vigentes e, consequentemente, não conseguir perceber as necessidades em saúde experimentadas e sentidas pelos indivíduos, tal como apontam os autores citados anteriormente neste capítulo.

As condições de vida da população moradora na área do Distrito Sanitário Boa Vista e a análise do discurso dos protocolos vigentes na SMS permitem afirmar que algumas das necessidades em saúde não serão atendidas nas Unidades de Saúde, pois, mesmo com dados que expressam situações nas quais os indivíduos se encontram em situações de vulnerabilidade para o desenvolvimento de agravos a saúde, não há nos protocolos previsão de intervenção para as mesmas. Entre essas situações se destacam o índice de jovens sem acesso ao trabalho, adultos analfabetos responsáveis por domicílios, 
comercialização e consumo de drogas ilícitas nas comunidades, violência e medo nas comunidades da periferia do município entre outras questões que foram citadas pelas próprias entrevistadas.

O processo de trabalho na Unidade de Saúde foi citado como um facilitador para o reconhecimento das necessidades em saúde. Atividades como reuniões com a participação dos outros profissionais das equipes locais e autoridade sanitária para discussões de casos com o objetivo de identificar o agravo e selecionar a intervenção a ser desenvolvida foram descritas e discussão de casos entre os profissionais da equipe também foi citada com o mesmo objetivo, mas não houve relato de desenvolvimento de intervenções multidisciplinares.

A finalidade da intervenção em saúde coletiva é a mudança do perfil do processo saúde-doença da coletividade. $\mathrm{O}$ trabalho das equipes locais de saúde possibilita esta mudança ao reconhecerem os processos determinantes das necessidades em saúde dos indivíduos e ao promoverem intervenções para transformar a realidade encontrada (Egry, 1996). A perspectiva de reversão do modelo de intervenção em saúde, curativista, hospitalocêntrico, está na mudança do modelo de gestão que historicamente tem gerenciado os meios para o desenvolvimento da assistência à saúde e não para promover estratégias que discutam a efetividade das intervenções para a transformação da determinação do processo saúde-doença (Paim, 2006).

Como se pode perceber, a realidade de saúde de Curitiba e, especialmente, do Distrito Boa Vista tem sido transformada ao longo dos anos, mas os dados apresentados no capítulo de resultados demonstram que ainda não se tem a realidade desejada. Ao contrário, ao mesmo tempo em que se promoviam intervenções para modificar os índices epidemiológicos elevados de determinados agravos outros emergiram, e situações que não eram identificadas como problema de saúde pública passaram a ser compreendidas dessa forma e, assim, objeto das intervenções em saúde. Logo, para gerenciar e intervir em saúde não se pode somente considerar dados de adoecimento e mortes consolidados nos perfis, ao contrário, tem-se que ir além da realidade objetiva na busca de identificar e analisar os processos que a determinam 
para intervir e promover a saúde e a vida com condições dignas para a população.

A articulação com as instituições locais para potencializar o reconhecimento de necessidades em saúde foi referida em todas as entrevistas. No discurso as instituições identificavam situações, agravos e riscos para o desenvolvimento de danos à saúde do usuário por estarem junto às comunidades e, posteriormente, buscavam as entrevistadas para relatar o encontrado no sentido de solicitar ajuda, assim como de propor ajuda nas intervenções. Entre as instituições citadas encontram-se igrejas, centros espíritas, associações de moradores, organizações não governamentais, serviços de educação pública, serviços de educação privados, serviço público de assistência social e farmácias.

A década de 1990 foi o período no qual o Estado Brasileiro transferiu não só a sua responsabilidade para Organizações Não Governamentais (ONGs) como também uma parcela considerável dos recursos públicos cumprindo a recomendação de organismos internacionais. As ações dessas instituições nos territórios de grandes centros urbanos têm representado a des-responsabilização do Estado em questões que deveriam ter a sua intervenção, pois são consideradas determinantes para a vida de indivíduos de classes mais pobres (Gohn, 2004; Cortes, 2002; Stotz, 2006).

Nas Conferências Municipais de Saúde e também nos protocolos analisados neste estudo há indicação de articulação dos técnicos do setor com o movimento social organizado para o desenvolvimento de intervenções que modifiquem a realidade de determinados agravos expressos nos índices epidemiológicos. Nas propostas aprovadas nas Conferências houve indicação de articulação com instituições não governamentais para promover intervenções em saúde em diferentes temas e em quase todos os eventos. Os protocolos e programas de saúde vigentes na SMS-CTBA também indicam a necessidade de articulação com representantes do movimento social organizado e instituições locais como estratégia para reverter os dados epidemiológicos apresentados.

Para Gohn (2004), nas décadas de 1980 e 1990 a implantação de mudanças na economia e a adoção de Políticas Públicas para determinados setores, entre eles a saúde, foram para implantar o Estado Mínimo no Brasil 
como recomendavam os organismos financeiros internacionais, Banco Mundial e Fundo Monetário Internacional (FMI). Entre essas recomendações estavam os incentivos para a criação de ONGs, associações e movimentos sociais nos grandes centros urbanos para que por meio destes organismos o Estado promovesse ações previamente estabelecidas para diminuir a desigualdade social que se tornara evidente. Para a autora, essas lideranças assumiram o papel de mediadores entre os cidadãos e os organismos internacionais, financiadores de ações previamente estabelecidas e, assim, substituíram o papel que deveria ter sido exercido pelo poder público no atendimento às demandas das comunidades.

Esse processo ocorreu contrariamente ao que o movimento popular reivindicava em sua construção histórica - mais presença do Estado nas comunidades periféricas dos grandes centros urbanos para atender às demandas dos excluídos e a garantia de participação dos representantes dessas comunidades na definição das Políticas Públicas para atender às suas necessidades. O repasse de recursos para os organismos não governamentais levou as associações, instituições e ONGs a se articularem com a população para garantir verbas e, assim, o desenvolvimento de ações locais. Instituições que não eram legítimas do movimento popular foram criadas pela necessidade da mediação entre os financiadores e os sujeitos a serem beneficiados. Nessa lógica de transferência de recursos, os critérios e as diretrizes para os projetos e programas foram estabelecidos e impuseram mudanças em entidades legítimas dos movimentos sociais organizados. As ações e atividades passaram a ser pontuais e focalizadas para grupos considerados prioritários, independente da realidade. Para garantir a captação de recursos os movimentos sociais legítimos foram levados a abandonar os princípios que buscavam construir, tal como a autonomia, cidadania e participação democrática (Cohn, 2003). 


\subsection{AS NECESSIDADES EM SAÚDE RECONHECIDAS}

As necessidades em saúde reconhecidas pelas entrevistadas emergiram dos discursos que descreveram situações nas quais haviam reconhecido e enfrentado necessidades em saúde. Quanto ao reconhecimento, foi afirmado que estes ocorriam em usuários, nas famílias, na comunidade e nas demandas na Unidade de Saúde.

As necessidades em saúde reconhecidas nos usuários foram descritas em situações nas quais se observou o agravo expresso na dimensão singular e particular. Nesta última, nos casos relatados foram identificados como sendo de usuários moradores de áreas de risco na comunidade, em grupos considerados homogêneos. As entrevistadas referiram que as moradias precárias eram devido a processos de determinação relacionados à dimensão estrutural destacando entre estes o não acesso ao trabalho e à renda. Assim, houve reconhecimento sobre a relação da não inserção na produção com o perfil de reprodução social e, consequentemente, este processo como determinante de necessidade em saúde. Apesar do reconhecimento sobre a determinação social e econômica para as realidades, as entrevistadas deram ênfase para as observações mais imediatas expressas em sinais, sintomas e queixas relacionados aos adoecimentos diagnosticados. Portanto, não exploraram suas percepções sobre a determinação das situações descritas e mantiveram o enfoque do discurso na dimensão singular.

No Distrito Boa Vista, o IPPUC (2008) identificou comunidades que vivem em terrenos de ocupação irregular e, assim, sem acesso regular à luz, saneamento básico e água tratada. Essas comunidades estão localizadas nas regiões mais periféricas dos bairros, logo nos limites entre os municípios da região metropolitana e Curitiba. Na região norte do município, Regional Boa Vista, esses espaços limítrofes foram pouco atendidos pela política de apoio à inserção de empresas no território municipal. Os bairros mais periféricos da zona norte ficaram fora do chamado "linhão do emprego". Essa política pública que teve início no ano de 1997 apoiou empresas que se encontravam no mercado informal com infraestrutura nos polos empresariais. 
A implantação de barracões empresariais ficou concentrada nos polos das regiões sul e sudeste do município. Na zona norte, região do Distrito Boa Vista, a maioria dos bairros não foi contemplada, a exceção foi para os bairros Tarumã, Bairro Alto e Atuba que ficaram próximos de uma área destinada a um dos polos definidos na política (IPPUC, 2008).

Para Marx (1985), as necessidades humanas são satisfeitas por meio de mercadorias, que são objetos de consumo externos ao homem. Heller (1986) define necessidades existenciais, naturais ou necessárias como sendo aquelas relacionadas à manutenção da vida humana, relacionadas à vida normal de indivíduos de uma determinada classe social em um determinado tempo em uma sociedade. Sem inserção no trabalho o indivíduo que vive em uma sociedade capitalista não tem como atendê-las. Os processos de produção e consumo de uma sociedade em um tempo histórico definem os potenciais de fortalecimento e de desgastes das pessoas que são expressos no processo saúde-doença individual e coletivo (Laurell, 1983).

Acredita-se que compreender o processo de exclusão social como determinado por processos da dimensão singular e particular, sem refletir sobre a determinação advinda de processos da dimensão estrutural é responsabilizar o indivíduo e a comunidade por sua realidade e, ainda, referendar ao Estado apenas o papel de regulador de mercado, no qual as mercadorias poderão ser adquiridas. Compreende-se que os processos na dimensão estrutural são definidores de Políticas Públicas para geração de emprego e renda, habitação, alimentação entre outros que deveriam atender às necessidades necessárias do indivíduo, logo da realidade objetiva de cada usuário e comunidade.

Foram citados também como necessidades em saúde a falta de informação para o desenvolvimento de cuidados em geral (filhos, casa, alimentação), a violência física e verbal, a falta de autocuidado, a baixa autoestima, a carência emocional, a falta de higiene pessoal, a falta de dinheiro, a falta de roupas adequadas, a falta de qualificação para o mercado de trabalho e a fome. A compreensão evidenciada nos discursos era de carência de algo ou de alguma coisa como necessidade em saúde. No discurso, a relação das situações descritas com processos estruturais determinantes 
nas realidades ficou restrito ao não acesso ao emprego e à desqualificação do indivíduo para os trabalhos oferecidos na região.

Quanto à ocupação de alguns usuários com o recolhimento de lixo reciclável, em casos relatados, a referência foi como as situações eram de risco à saúde destes sujeitos, das suas famílias, como também da comunidade. Segundo as entrevistadas, o material recolhido pelos moradores era depositado nos terrenos ao redor de suas casas e, muitas vezes, foram encontrados espalhados pela comunidade comprometendo a saúde da população local e recursos naturais que havia no território. Reflexões sobre por que esta atividade passou a ser a única possibilidade de renda de algumas famílias daquelas comunidades não foram expressas, apesar de reconhecerem que a atividade era árdua, insalubre e que representava um significativo desgaste para os sujeitos que a executavam. Também foi reconhecido que esses indivíduos não estavam preparados para o mercado de trabalho formal por falta de escolaridade e qualificação. Em alguns casos descritos houve encaminhamentos para cursos preparatórios de atividades profissionais. Porém, quanto à qualificação foi descrito que não houve muito interesse por parte da população local, porque em alguns cursos não houve demanda para o número de vagas ofertadas. Entre os cursos mencionados havia formação para as atividades na função de pedreiro, auxiliar de pedreiro, padeiro e porteiro.

As entrevistadas reconheceram que algumas famílias e indivíduos moradores da área de abrangência eram envolvidos com o narcotráfico local e algumas mortes violentas nas comunidades foram relacionadas à atividade da pessoa com o tráfico de drogas. Foram descritos casos de extrema violência na comunidade, entre estes foi relatado a morte da mãe e filho adolescente decapitados na comunidade. Ao relatar a situação a entrevistada se emocionou e disse que tinha cuidado do adolescente assassinado na Unidade de Saúde desde a puericultura, mas que já sabia do envolvimento dele e da mãe com o tráfico de drogas. Referiu que mesmo transcorrido algum tempo (o caso ocorrera a mais de um ano da data da entrevista) persistia um sentimento de impotência diante de realidade tão cruel.

Segundo os discursos das conferências analisadas, a violência passou a ser abordada em propostas de intervenção em saúde a partir da 
6. ${ }^{a}$ Conferência Municipal de Saúde (2001) e, assim, passou a ser tema de propostas discutidas e aprovadas nos eventos seguintes. Em 2003, na 7. ${ }^{a}$ Conferência, foi aprovada proposta que recomendou a criação das Redes de Proteção ao idoso, à criança e adolescente e à mulher, nestas os serviços de saúde passariam a participar em conjunto com instituições locais de outros setores, em ações preventivas articuladas para proteger os indivíduos que viviam em situação de risco para a violência. As propostas de intervenção têm sido baseadas no risco, na probabilidade de vir a ocorrer um ato de violência com indivíduos em situações consideradas favoráveis para tal. Assim, conforme referenda o protocolo, os membros da Rede de Proteção identificam indivíduos e grupos, em situações de risco para a violência, que vivem no território que está sob a sua responsabilidade para promover ações articuladas de prevenção da violência e proteção da vida.

Estudos sobre a violência e dados epidemiológicos sobre morbimortalidade por causas externas em Curitiba foram citados na apresentação dos resultados. Os dados apresentados mostraram que os índices de violência têm aumentado no município e que morte por causas externas representou a terceira causa de óbito no ano de 2006, como também foi a terceira causa de internação no SUS no mesmo ano. Com relação aos óbitos por causas externas, o grupo mais atingido foi do sexo masculino na faixa etária de 15 a 29 anos (Curitiba, 2008b).

No período de 2003 a 2006 a mulher aparece nos dados sobre morbimortalidade por causas externas como a maior vítima de violência, sendo identificada a violência sexual como o tipo mais frequente. Com relação à violência contra criança e adolescentes nos dados referentes a 2006, tevese que a faixa etária predominante foi de 5 a 9 anos, a Fundação da Ação Social (FAS) foi a instituição que mais notificou casos deste grupo, seguida de notificações de escolas municipais, hospitais e unidades de saúde. Os casos notificados mostraram predominância da violência intrafamiliar (90\% do total), sendo a negligência a violência mais notificada. Nos casos de violência extrafamiliar ( $10 \%$ do total), a natureza da violência mais frequente foi sexual (Curitiba, 2008b). 
Em estudos desenvolvidos pela Secretaria de Segurança do Estado do Paraná sobre violência em Curitiba chamaram a atenção algumas questões: na percepção do cidadão o furto é o crime que mais ocorre na cidade; $59,9 \%$ dos entrevistados referiram que não fizeram ocorrência policial porque não acreditavam que as instituições policiais teriam soluções para eles; houve referência dos entrevistados para a sensação de risco de ocorrências com policiais (agressão ou extorsão); a sensação de falta de segurança na cidade era maior para os entrevistados com renda inferior a 11 salários mínimos (Paraná, 2007).

Com relação às medidas para reduzir a violência, 90\% entrevistados do estudo não conheciam medidas adotas nas suas comunidades. Para os $10 \%$ de entrevistados que reconheceram medidas adotadas nas comunidades, a referência foi para ações promovidas por instituições locais como: igreja, moradores da vizinhança, associação de bairro, conselho de segurança comunitária, ONGs e associações políticas. Para aqueles que reconheceram a segurança feita por moradores voluntários da vizinhança, uma parte significativa referiu que a segurança era realizada por gangues ou pessoas ligadas ao tráfico de drogas (Paraná, 2007).

A percepção sobre fatos relacionados a crimes e nível de desordem social na vizinhança era maior para os entrevistados moradores de bairros mais violentos do que os moradores dos bairros menos violentos, sendo que $75 \%$ dos moradores de áreas violentas já presenciaram ou ouviram falar de crianças e adolescentes vítimas de violência pelos pais. A agressão física contra mulheres pelos maridos foi referida por $40,38 \%$ dos entrevistados moradores de áreas violentas e por $27,94 \%$ dos moradores de áreas não violentas. A violência sexual foi referida por $26,92 \%$ dos entrevistados moradores de áreas violentas e por $14,80 \%$ dos moradores de áreas não violentas (Paraná, 2007). No período de 1997 a 2001, o bairro da regional Boa Vista com pior desempenho para aos índices de segurança e mortalidade por causas externas foi o Tarumã. Com relação aos acidentes de trânsito atendidos pelo SIATE no ano 2000, o Bairro Alto registrou os maiores índices (IPPUC, 2005).

Segundo Luiz e Cohn (2006), as mudanças ocorridas nas sociedades modernas são representadas nas estruturas das famílias. A noção de risco 
passa a ser representada por cálculos, percepções e comunicação sobre o risco no sentido de prever um futuro controlável pela mudança de comportamento do indivíduo. A informação e o monitoramento para vigiar e controlar estabelece nova forma de viver em sociedade. $\mathrm{Na}$ saúde as probabilidades são direcionadas para os cálculos que representam características individuais que levarão ao desenvolvimento de um evento adverso - a doença. Assim, determinados comportamentos, hábitos, estilos de vida devem ser abandonados. As medidas adotadas e recomendadas enfocam a dimensão singular para alterar processos estruturais determinantes. Para os autores, a análise de risco justifica a alocação de verbas públicas para atender às demandas de grupos menos favorecidos, os quais estão sob o risco, com intervenções para diminuir a desigualdade social sem discutir Políticas Públicas mais amplas de inclusão social que possam ir contra o interesse de classes dominantes.

Barata (2006) afirma que a desigualdade social no paradigma de risco se confunde com o conceito de privação e o modelo de estratificação social passa a ser pela capacidade de distribuição e consumo de bens e não pela inserção no processo produtivo. Os aspectos da vida são tomados como sendo uma opção individual, ou seja, como resultado do empenho de cada um. Para a autora, as consequências de estudos com este enfoque são a perda do poder de denúncia sobre os processos que determinam a desigualdade e, consequentemente, a conformação de uma sociedade que acredita que o esforço individual vai garantir a mobilidade social do indivíduo.

Quanto aos agravos descritos como necessidades em saúde os mais citados foram relacionados aos transtornos psiquiátricos, principalmente a dependência química, seguido de relatos sobre as doenças crônicas (hipertensão e diabetes), doenças infecto-contagiosas (HIV, tuberculose, escabiose e verminose), usuários idosos portadores de dependências por complicações de doenças crônicas, gestação de alto risco e neoplasias. Nas situações relatadas, os idosos, as mulheres na fase de reprodução, os adolescentes e as crianças foram os grupos apontados como portadores de necessidades.

Todos os agravos citados pelas entrevistadas foram temas de propostas de intervenção em saúde nas Conferências do setor estudadas e na assistência à saúde prevista nos protocolos vigentes na SMS-CTBA. Com relação à 
assistência à saúde mental foram aprovadas propostas de intervenção em todos os eventos ao longo dos dez anos. Nas entrevistas as enfermeiras descreveram situações de intervenções desenvolvidas pela equipe local para adoecimentos mentais que ocorrem com apoio de profissionais de instituições contratadas pelo SUS e de profissionais da equipe de saúde mental do Distrito Sanitário. Estes profissionais se deslocam até a unidade com agendamento prévio para atender, acompanhar e discutir com a equipe local os casos que necessitam da intervenção na área de saúde mental.

$\mathrm{Na}$ análise dos protocolos se percebe que o enfoque de risco é norteador das intervenções a serem desenvolvidas. Este mesmo enfoque é percebido nas propostas aprovadas para intervenção que estão nos discursos das Conferências de Saúde, porém nos relatos sobre as intervenções que desenvolveram para usuários portadores dos agravos acima citados as entrevistadas demonstraram que compreender nas demandas a subjetividade dos usuários no momento que entravam em contato com suas realidades. Assim, referiram perceber sentimentos que emergiram dos usuários e familiares nas consultas e visitas domiciliárias e, também, demonstraram que perceberam que as complicações apresentadas pelos portadores de agravos crônicos estavam além dos aspectos observáveis no corpo do indivíduo.

Dentre as situações descritas referiram sentimentos como o nervosismo do pai hipertenso grave ao ter que lidar com o filho usuário de crack, a mãe portadora de doença crônica angustiada porque teve de aceitar o filho com problemas financeiros e de saúde de volta à sua casa, a cuidadora idosa portadora de doenças crônicas ansiosa pela dificuldade de deslocamento do seu companheiro até a Unidade de Saúde para receber procedimentos de enfermagem necessários, a inibição e vergonha dos membros de uma família que ao serem atendidos na rotina da Unidade de Saúde não conseguiam expressar suas reais e precárias condições de vida.

Ayres (1997) e Breilh (2006) consideram que para compreender o processo saúde-doença do indivíduo é necessário entender não somente os processos determinantes nas diferentes dimensões da realidade, mas também é preciso compreender a subjetividade do indivíduo no processo. Nesse âmbito do indivíduo, segundo os autores, as intervenções que são racional e 
tecnicamente desenvolvidas podem ou não ser potencializadas. Breilh (2006) aponta que é preciso também considerar no processo de atenção à saúde as diversidades culturais, com destaque para as culturas contra-hegemônicas, no sentido de propor e sustentar projeto de intervenção emancipador.

Nas situações em que as entrevistadas relacionaram necessidades em saúde de adolescentes identificaram a própria adolescência, a drogadição e a gravidez como as questões frequentes neste grupo a serem enfrentadas nos territórios. Os relatos foram de situações nas quais as entrevistadas necessitavam de intervenções articuladas com outros setores e com os familiares dos menores. Com relação às necessidades em saúde de crianças foram descritas situações nas quais estes sujeitos eram portadores de problemas de comportamentos e houve destaque para alta frequência de diarréias nos usuários dessa faixa etária. Os problemas de comportamento foram relacionados às situações que a Rede de Proteção teria identificado e que tinham necessidade de intervenções preventivas por meio de um trabalho interinstitucional e multiprofissional. Para intervenções nos casos de diarréias, os relatos apontaram as notificações realizadas e o desenvolvimento de ações preventivas e de promoção à saúde para evitar o aparecimento de novos casos. Os determinantes da diarréia foram referidos como sendo as condições de moradia e de higiene em geral.

As necessidades em saúde dos usuários idosos foram relacionadas ao processo de envelhecimento e às doenças crônicas degenerativas que os levava à dependência para cuidados a serem desenvolvidos nos seus domicílios. Além desses usuários, outros indivíduos foram identificados como dependentes de atendimentos domiciliares. Para as entrevistadas eram usuários que não poderiam se deslocar até a Unidade de Saúde por serem portadores de debilidade física em consequência de algum agravo.

Ao identificarem os adolescentes, o idoso, os adoecimentos e as complicações destes como sendo necessidades em saúde, as entrevistas expuseram discursos coerentes com as Conferências Municipais de Saúde, uma vez que as propostas de intervenção aprovadas eram para segmentos da população segundo faixa etária e adoecimentos. Em relação à adolescência e ao envelhecimento, compreendidos como necessidade em saúde, cabe 
registrar que a percepção do profissional direcionou para o indivíduo, segundo a fase do seu ciclo de vida, a falta de condições para a vida nas comunidades e nas famílias. As poucas opções para os indivíduos de classes mais pobres da comunidade de acesso ao trabalho, a capacitação para o trabalho e, também ao lazer, em um território, que tem somado a essas questões a instalação do tráfico de drogas, como já relatado anteriormente, apontam processos de desgastes o jovem na comunidade. Em relação ao tráfico de drogas as possibilidades do adolescente se envolver são tanto para o consumo, como para o trabalho junto ao tráfico ou para ser vítima da violência que emerge da situação. Portanto, pela caracterização do território e pelo discurso das entrevistadas, compreende-se que a ausência de Política Pública para a inclusão desses sujeitos em projetos de preparo para o trabalho articulado com atividades de lazer e educação os torna portadores de necessidades em saúde.

Ao falar de necessidades em saúde reconhecidas e enfrentadas junto às famílias as enfermeiras descreveram situações nas quais observaram ausência de cuidados entre os membros dos grupos. As dinâmicas dos relacionamentos no núcleo familiar e a estrutura das famílias foram descritos como fatores protetores ou de desgastes para a saúde. Os desgastes foram relacionados às situações nas quais encontraram desresponsabilização dos familiares com seus dependentes, conflitos nos relacionamentos pelo adoecimento de um dos membros e mudanças no ciclo de vida e a chegada do(s) novo(s) membro(s) no grupo. Os conflitos entre os membros da família e destes com a equipe de saúde foram descritos em situações de violência nas famílias, pois as dificuldades e falta de suportes para enfrentar tais situações geraram atitudes agressivas de usuários com a equipe. A composição familiar foi apontada como necessidade em saúde, entre os casos relatados destacamse: famílias com vários filhos pequenos e famílias compostas de mulheres de mais de uma geração com filhos e sem companheiros.

A descrição de situações nas quais reconheceram necessidades em saúde é coerente com os discursos das Conferências estudas. Nas propostas de intervenção aprovadas, conforme já demonstrado no capítulo de resultados, observam-se intervenções para prevenir adoecimentos e promover a saúde 
dos indivíduos segundo as mudanças no ciclo de vida. As dinâmicas de relacionamentos nas famílias também estavam contempladas nas propostas aprovadas nos eventos, mas nestas a preocupação era responsabilizar os familiares pelos cuidados com os dependentes, crianças, idosos e portadores de deficiência.

Nos dados de caracterização do município são referidos dados populacionais que mostram o envelhecimento da população curitibana e a queda na natalidade. Essa tendência também pode ser observada nos dados da população da Regional Boa Vista, sendo que na regional há maior expressividade da população de jovens e de idosos comparado à população do município (IPPUC, 2005).

Nos programas de saúde da SMS-CTBA estão previstos os protocolos para a assistência à saúde destes grupos, o avanço que se pode observar no discurso dos documentos analisados foi em relação às Redes de Proteção para indivíduos em situação de risco para a violência. Porque é uma proposta elaborada com a participação de diferentes segmentos da sociedade, com recomendação para intervenções multidisciplinares e intersetoriais. Porém, apesar do avanço apontado, o enfoque de risco é norteador das intervenções e não há reflexão e orientação de intervenção sobre os processos estruturais determinantes das situações de violência. O que se encontra no protocolo é que as condições sociais e econômicas das famílias são fatores favoráveis e desencadeantes da violência.

Ainda com relação à violência, houve avanços que cabem registrar, pois a partir da $7 .^{a}$ Conferência (2003) foi aprovada proposta que indicava intervenção no sentido de que o indivíduo identificado como agressor, em casos de violências leves, fosse atendido pelos serviços de saúde para se buscar as causas de suas ações e, assim, reverter seu comportamento para recuperá-lo para o convívio social saudável. Porém, não foi apontado qual seria o serviço de saúde mental que atenderia a este sujeito.

Quanto aos cuidados que os familiares deveriam ter entre si para promover a saúde e prevenir os adoecimentos ou suas complicações, as entrevistadas apontaram que em muitas situações atendidas não havia quem assumisse o papel de cuidador no domicílio e, ainda, casos nos quais 
não se tinha condições materiais mínimas para se desenvolver o cuidado. Assim, a falta de renda, alimentação e higiene foram referidas como fatores que dificultaram a assistência domiciliar reforçando a compreensão sobre a necessidade de acesso ao trabalho e renda para as famílias, como já foi referido anteriormente neste capítulo. Nos casos em que se apontou a necessidade de cuidadores para adolescentes teve-se a compreensão desses indivíduos como sendo aqueles que necessitariam da autoridade e controle da família para não se envolverem com drogas e violências presentes nas suas comunidades. Nos casos dos cuidadores para os idosos e para as crianças, a referência foi pela dependência de um responsável para o atendimento às questões relacionadas muitas vezes à sua sobrevivência, tais como a alimentação e proteção.

Segundo a compreensão das entrevistadas as necessidades em saúde na comunidade ocorriam pela precariedade das condições de vida, pela falta de acesso ao trabalho e consequentemente à renda, moradia e alimentação. Porém, a exclusão social foi compreendida, conforme se descreveu nos casos relatados anteriormente, por características da própria comunidade e que era típica em grupos que viviam na periferia de uma cidade grande como Curitiba.

O movimento de migração no Paraná mostra que trabalhadores rurais e suas famílias se deslocaram para os centros urbanos em busca de oportunidades de trabalho uma vez que o desenvolvimento econômico do Estado levou a concentração da base produtiva para municípios sedes dos polos regionais e a produção rural passou a ser em grandes latifúndios com o uso de tecnologias avançadas para o aumento da produtividade de uma única cultura. A desigualdade social se acentuou nesse processo e, assim, os territórios urbanos foram ocupados, principalmente nas cidades sedes. Nesses municípios as pessoas passaram a viver em territórios periféricos, sem que houvesse condições mínimas para a construção de habitações. Todo esse processo teve consequências não só na saúde das pessoas como também no meio ambiente (IPARDES, 2004a). Para Oliveira apud IPARDES (2004a), a mesorregião metropolitana de Curitiba apresenta a desigualdade social visível em seus territórios. Para a reversão desta 
situação o autor aponta que as forças sociais e políticas devem promover ações governamentais no sentido de garantir a distribuição de renda e, consequentemente, a inclusão social.

Ayres (1997) e Barata (2005) chamam a atenção para as limitações de estudos epidemiológicos que identificam o adoecimento como uma expressão individual e biológica distribuído em um determinado espaço geográfico sem relacioná-lo aos processos estruturais determinantes da vida naquele território. Segundo Breilh (2006), na designação de riscos emerge a compreensão de algo que é provável em uma sociedade na qual a desigualdade é produzida estruturalmente. Este paradigma para o autor referenda a compreensão sobre fatores de riscos como variáveis não permanentes e possíveis de serem controladas, fazendo com que se acredite na possibilidade da plena saúde, pois nega a dominação do processo de produção sobre o indivíduo.

As necessidades em saúde expressas nas unidades de saúde foram relacionadas às demandas dos usuários para receberam ações e atividades programáticas desenvolvidas nos serviços. Nas intervenções descritas as de caráter curativo eram as mais procuradas, sendo a consulta médica a atividade com maior demanda. Para algumas entrevistadas a não adesão às intervenções de caráter preventivo realizadas nos serviços de atenção básica e a falta de renda para transporte ou para pagar por serviços de apoio diagnóstico ou atendimentos especializados foram apontadas como necessidades em saúde.

Os princípios e as diretrizes do SUS apontam que serviços privados podem ser contratados como complementares à rede pública quando esta não dispõe dos mesmos recursos ou quando a oferta pública é insuficiente para promover a assistência integral à saúde do usuário. Essa complementaridade está apontada nas diretrizes do SUS e regulamentada nas leis e normas vigentes para o setor. Nas propostas aprovadas nas Conferências de Saúde, a complementaridade do setor privado é apontada e o sistema municipal tem ações que são desenvolvidas por prestadores de serviço. Acredita-se que o reconhecimento desta demanda como necessidade em saúde é pela insuficiência ou inadequação de oferta de intervenções para a atual demanda do sistema público de saúde, bem como dos serviços complementares. 
A reflexão das entrevistadas não relacionou as necessidades em saúde observadas nas unidades com a dimensão particular da realidade de saúde, ou seja, com a organização dos serviços, programação em saúde e protocolos vigentes, que definem o modelo de intervenção em saúde. O modelo de atenção com enfoque curativista, médico centrado, prevalece na prática sanitária mesmo que nas diretrizes dos programas e nas atividades a serem desenvolvidas pela equipe, sejam descritas ações de promoção da saúde e prevenção de doenças para serem desenvolvidas. Intervenções de promoção à saúde e prevenção de adoecimentos têm sido o enfoque das regulamentações do Sistema Único de Saúde nos últimos vinte e cinco anos. Porém, ao longo desse período não se conseguiu avançar com o enfoque nas práticas sanitárias locais para reverter o modelo de atenção à saúde curativista. Para Campos, Barros e Castro (2004), a promoção da saúde, segundo o conceito de saúde ampliado preconizado pelo SUS, pressupõe o desenvolvimento de ações intersetoriais com ampliação de cobertura e garantia de acesso segundo as necessidades em saúde sentidas pelos usuários. Cabe ao Estado implantar políticas sociais e econômicas mais justas para que se modifique a determinação do processo saúde-doença e se promovam condições dignas de vida para a população, além de reverter o modelo da prática sanitária local.

Outra questão a ser destacada é que a demanda para o consumo de intervenções não é um movimento próprio do usuário ou da família, ao contrário é a expressão de um movimento construído histórica e coletivamente sobre as necessidades em saúde que determinam a necessidade expressa individualmente.

\subsection{O ENFRENTAMENTO DAS NECESSIDADES EM SAÚDE RECONHECIDAS}

Como já descrito anteriormente para o desenvolvimento de intervenções para o enfrentamento das necessidades em saúde reconhecidas as entrevistadas referiram a importância de se conhecer a realidade do usuário e da família 
para compreendê-la e assim intervir. Descreveram intervenções desenvolvidas nas unidades de saúde; intervenções no domicílio; intervenções segundo o modelo de atenção à saúde; intervenções para promoção da saúde e prevenção de doenças; intervenções articuladas com outros setores e serviços de saúde de outros níveis de complexidade; intervenções desenvolvidas em equipe; capacitação da equipe para intervir; intervenções com a mobilização da comunidade, família e usuários, e intervenção com a participação da família.

Nos discursos o conhecimento da realidade das situações descritas ocorreu no imediato, sobre aquilo que podia ser observado no cotidiano dos sujeitos, conforme já referido nesta discussão. Logo, não houve identificação dos processos históricos, sociais e econômicos na determinação daquilo que estavam descrevendo. Em muitas situações essas relações estavam claras, como nos casos de adultos desempregados, famílias sem renda, violência na família contra o idoso, gravidez na adolescência, adolescente grávida envolvida com o tráfico e uso de crack, morte violenta na comunidade de indivíduos envolvidos com o tráfico de drogas.

Ao descreverem os casos nos quais realizaram intervenções o discurso das entrevistadas foi convergente com os dados da caracterização do município e com as propostas aprovadas nas Conferências Municipais de Saúde, pois os índices epidemiológicos e populacionais apontaram que na periferia do território municipal se encontram os grupos com menor renda, os índices elevados de morte de jovens por causas externas dentre outros dados.

Em alguns casos relatados já havia situações irreversíveis, como os óbitos por causas externas na comunidade. Nos relatos de casos relacionados à presença do tráfico na comunidade foram descritas dinâmicas do comércio e consumo de drogas em locais próximos às unidades de saúde, mas não houve relato de intervenção articulada com outro setor para mudar estas situações. Segundo as entrevistadas, houve tentativas de se realizar intervenções para o usuário dependente químico pela equipe da Unidade de Saúde articuladas com os serviços credenciados de saúde mental ou por meio de encaminhamentos para a assistência à saúde no serviço de emergência para viabilizar internação hospitalar. As intervenções que seriam desenvolvidas nas unidades eram de formação de grupos de apoio para auxiliar o tratamento 
da dependência química, mas não houve adesão dos usuários convidados a participar.

Heller (1986) afirma que necessidade individual é submetida à necessidade coletiva social e historicamente construída. Em uma sociedade capitalista a satisfação das necessidades necessárias ou naturais depende do nível cultural da sociedade e da exigência da classe dos trabalhadores e seus representantes para conquistarem a valorização da força de trabalho para garantir meios que atendam às suas necessidades necessárias que variam de acordo a cultura e condições climáticas de cada país.

Para Stotz (1991), a redução sobre a compreensão de necessidades como algo expresso individual e biologicamente devido ao desgaste sofrido tem sido a prática do sistema institucionalizado de saúde. Considera esse um processo que impede o indivíduo de refletir sobre a determinação do seu processo saúde-doença e que autoriza ao Estado normatizar para intervir em saúde, definindo as demandas a serem atendidas nos serviços do setor, um processo de exclusão de parte das necessidades expressas individualmente. Pois, as necessidades em saúde a serem satisfeitas nos serviços de saúde seguirão padrões previamente estabelecidos e não de acordo co cada realidade.

Segundo Mendes-Gonçalves (1992), nas sociedades com distribuição e consumo dos processos de trabalho desiguais as necessidades deixam de ser naturais porque são construídas socialmente e, portanto, representam as necessidades de produção e reprodução do modo de produção. O atendimento às necessidades naturais ou necessárias em cada família está relacionado à reprodução social que, logicamente, em uma sociedade capitalista depende da inserção do indivíduo na produção. Logo, as necessidades mesmo sendo necessárias para a vida só serão atendidas de acordo com as possibilidades e obstáculos que se têm em um espaço que é histórico e socialmente construído. Todo esse processo é dependente e marcado pelos condicionamentos econômicos, culturais, políticos em cada classe social e nas relações de gênero e étnicas que as caracterizam (Breilh, 2006). O que se acredita ser possível perceber antes de haver a expressão individual de necessidades. Em análises sobre as condições de vida e trabalho da população, principalmente nas classes mais pobres, se observam dados que indicam processos de desgastes 
e ausência de processos protetores individuais e coletivos nas dimensões que conformam a realidade objetiva. Logo, esses deveriam ser a referência para a organização das intervenções e serviços de saúde para reverter o atual modelo individualista, biologicista e curativista.

As intervenções desenvolvidas na Unidade de Saúde foram do atendimento à demanda espontânea com predominância de atividades curativas e de apoio diagnóstico para os indivíduos com agravos já instalados. Para atender ao usuário se considerava a capacidade instalada na Unidade de Saúde e, principalmente a possibilidade de agendar consulta médica. A demanda para a consulta médica reforçava a centralidade da intervenção neste procedimento, fenômeno coerente com a própria lógica da programação em saúde que se analisou neste estudo. Nos casos de usuários que necessitavam receber procedimento e não podiam se deslocar até a Unidade, orientava-se para que estes fossem trazidos por familiares, vizinhos ou, no impedimento e falta de recursos, se deslocavam profissionais até o domicílio independente de se ter a ESF implantada. Nos relatos foram identificados deslocamentos de profissionais da equipe de enfermagem e ACS. Nas unidades sem ESF os usuários que necessitavam de intervenções de outros profissionais da equipe eram encaminhados para outros serviços, pois não se tinha disponibilidade para tais deslocamentos.

Com a mobilização da comunidade, família e usuários para desenvolver intervenções as entrevistadas procuravam garantir recursos, para os quais o Estado não apontava soluções na medida em que o usuário demandava. As necessidades deveriam ser atendidas com soluções imediatas por comprometerem a saúde e a manutenção da vida do usuário ou da família. Entre os casos destacam-se: usuários com prescrição de medicamentos sem recursos para adquirir, famílias sem renda e que necessitavam de cestas básicas, usuários sem recursos financeiros para o deslocamento para atendimentos em serviços especializados conforme encaminhamentos, usuários sem documentação de identificação, desemprego de adultos responsáveis por família e idosos acamados que viviam com familiares sem condições de se responsabilizar pelo desenvolvimento dos cuidados de higiene e alimentação. 
No discurso o voluntariado e a mobilização das lideranças foram compreendidos como um potencial da comunidade para o desenvolvimento de algumas intervenções. $O$ voluntariado era a possibilidade de se realizar cuidados gerais para usuários dependentes nos domicílios sob a supervisão da equipe de saúde local, pois esta não dispunha dos recursos necessários, mas poderia orientar e acompanhar as atividades. A mobilização das lideranças era importante para ajudar a promover o acesso à cesta básica, medicamentos, transporte e trabalho, como já citados acima.

A histórica luta dos movimentos sociais organizados no Brasil teve o objetivo de garantir Políticas Públicas que atendessem às necessidades das classes excluídas do processo de produção e de decisões para Políticas Públicas. Logo, um movimento das classes mais pobres que se posicionou contrário aos interesses das classes dominantes da sociedade (Gohn, 2004). Para esse movimento, o Estado atendia aos interesses daqueles que pertenciam às classes dominantes em detrimento das classes populares que não tinham como se contrapor e exigir políticas que promovessem condições mínimas de vida para seus grupos (Valla,1998).

Segundo Cortes (2002), nas últimas décadas o alinhamento dos países de economias periféricas, como é o caso do Brasil, às políticas econômicas recomendadas por agências internacionais tem levado a sociedade a novas interpretações sobre o atendimento às demandas das classes populares, assim como da compreensão sobre a própria participação popular na luta por Políticas Públicas que atendam às suas demandas. Quanto à exclusão social, a compreensão que se estimulou no período foi que esta é um fenômeno que ocorre pela ignorância e passividade dos cidadãos. Portanto, não se promove a reflexão sobre os processos macroestruturais na determinação deste fenômeno. A recomendação para atender às demandas expressas pelas classes populares é para que esta seja minimamente atendida, com pacotes de ações já previamente estabelecidos em políticas adotadas pelo Estado.

No discurso analisado das Conferências Municipais de Saúde houve registro de aprovação de propostas para a capacitação de representantes do movimento social organizado em todos os eventos, no sentido de garantir participação efetiva na definição de políticas do setor. Nas propostas a formação 
seria promovida pela própria Secretaria de Saúde Municipal. Acredita-se que a preocupação dos autores, acima citados, sobre o movimento social organizado nas últimas décadas é coerente com aquilo que se pode observar nos resultados deste estudo. Porque nos discursos, tanto das entrevistadas como das Conferências, foi reconhecido um papel para o movimento social organizado diferente daquilo que historicamente é reivindicado pelos movimentos populares. Assim, a preparação dos representantes do movimento popular para exercer o seu papel por organismos do Estado, o qual historicamente foi denunciado por adotar Políticas Públicas que atendiam aos interesses das classes hegemônicas e excluíam as classes mais pobres, é contraditória. Se refletirmos que a aprovação para a realização da proposta de formação pela Secretaria de Saúde se deu em fóruns que havia representantes do movimento e, que estes tinham o direito ao voto na aprovação ou não, fica aberta a reflexão sobre como os representantes dos movimentos sociais legítimos percebem esta contraditória questão.

Para o desenvolvimento das intervenções, as entrevistadas referiram seguir o modelo de atenção à saúde segundo os pressupostos e diretrizes dos programas de saúde implantados na Unidade de Saúde que trabalhavam. Em unidades sem a implantação da ESF houve a comparação entre as intervenções que eram realizadas e as diretrizes estabelecidas pela estratégia. A comparação ocorreu porque nos relatos de intervenções era dito que, apesar de não haver a ESF, naquele serviço a equipe procurava visitar e conhecer a comunidade para descrever o território e identificar as condições socioeconômicas das famílias. Entre as intervenções realizadas foram citadas as visitas domiciliárias e os cuidados nos domicílios.

As entrevistadas afirmaram que ao se aproximarem das famílias tinham a preocupação de não impor seus valores pessoais e técnicos. Porém, buscavam trabalhar com o grupo visitado as suas responsabilidades para 0 enfrentamento dos agravos ali reconhecidos. A responsabilização foi referida principalmente para os casos nos quais houve identificação de dependência para receber cuidados em algum familiar e, também, em casos relacionados à não adesão de usuários aos tratamentos para doenças infecto-contagiosas ou controle de doenças crônicas prescritos. A dependência de familiares 
compreendida em casos de filhos menores de idade cuidados pelos pais, filha deficiente física e mental acamada cuidada pela mãe e casos de familiares idosos dependentes dos cuidados de adultos jovens.

Ao orientarem sobre os cuidados e as responsabilidades, posteriormente as entrevistadas acompanhavam a família por meio de visitas domiciliárias. O acompanhamento se dava por meio de visitas domiciliárias feitas pela equipe de saúde ou pela própria enfermeira. Nos casos em que a realização do acompanhamento era delegada para os auxiliares de enfermagem ou ACS, a supervisão sobre os trabalhos da equipe permitia que a enfermeira, indiretamente, acompanhasse a situação.

O processo de descentralização dos serviços ocorridos nos últimos anos no Brasil tem aproximado os serviços de saúde à realidade local, porém muitos desafios ainda se colocam. Segundo o Ministério da Saúde (Brasil, 2006) a gestão deve ser qualificada, o modelo fragmentado de atenção à saúde tem que ser superado e a rede de serviços tem que ser organizada no sentido de construir uma proposta regionalizada, hierarquizada e resolutiva. Para Breilh (2006), Mendes (1998), Paim (1999), Egry (1996), o atual foco das intervenções em saúde é a doença e a reversão do modelo de atenção à saúde está relacionada à mudança deste o foco para as necessidades em saúde e nos processos de determinação do processo saúde-doença.

Ao desenvolver a intervenção o trabalhador de saúde segue normas e diretrizes de programas e, por muitas vezes, repete ações fragmentadas que não consideram o usuário com o direito de participar de decisão no processo da assistência à sua saúde. Para Mendes-Gonçalves (1992), o trabalho em saúde é elaborado considerando que as dimensões da realidade estão externas a ele. Como dimensão interna, considera a forma de pensar técnica e cientificamente a criatividade, o humanismo e a neutralidade. Logo, permite-se elaborar uma única forma de intervir à qual a realidade deve ser adequada.

Trabalhar em equipe promovendo a integração entre os profissionais e destes com os usuários foi compreendido como importante para a intervenção resolutiva em saúde. Para as entrevistadas, o envolvimento dos sujeitos nos processos de planejamento, desenvolvimento, acompanhamento e avaliação 
das ações seria um facilitador para que os objetivos propostos fossem atingidos tanto em intervenções para o enfrentamento de agravos como de ações para a promoção da saúde. A articulação entre os profissionais para promover a intervenção também foi citada no sentido de potencializar ações resolutivas. As ações para suprir demandas de caráter social, tais como dar dinheiro ou vale transporte, para facilitar e garantir que o usuário tivesse acesso ao que lhe prescrito, foram ponderadas como algo que se fazia por não haver outra possibilidade de recursos com a agilidade necessária. Ao relatarem os casos as entrevistadas refletiram sobre a atitude adotada juntamente com a equipe, mas afirmaram que muitas vezes essa era é a única opção.

A necessidade de capacitação da equipe para o desenvolvimento de intervenções que deveriam ir além dos sinais e sintomas, expressos por usuários portadores de agravos, foi falada pelas entrevistadas quando refletiram sobre as suas próprias limitações para intervir diferentemente do modelo vigente, curativista e hospitalocêntrico. Assim, demonstraram compreender que as condições socioeconômicas determinavam as condições de vida, o adoecimento e a morte dos moradores das áreas de abrangência das unidades de saúde e que algumas intervenções que desenvolviam tinham limites para transformar aquelas realidades.

Para Fonseca e Bertolozzi (1993), avaliar as condições de saúdedoença do ponto de vista da saúde coletiva é identificar os processos destrutivos ou benéficos para a saúde da população-alvo do serviço de saúde. É buscar no indivíduo a expressão singular das condições de vida possibilitadas pelo processo de reprodução social do grupo ou classe social em uma determinada sociedade, refletindo que a individualidade se estabelece entre as pessoas na construção da vida social. Em modelos de intervenção em saúde previamente estabelecidos já se têm os resultados esperados, logo se seguem ações e atividades prescritas. Nessa perspectiva, são negadas as especificidades das situações a serem enfrentadas e não se reflete sobre a historicidade, relações e contradições existentes no evento e deste com outros processos nas diferentes dimensões da realidade.

A compreensão de que o processo saúde-doença expresso pelo indivíduo é apenas uma expressão de condições que indicam o equilíbrio/ 
desequilíbrio ou de normalidade/anormalidade, desconectado da visão social mais ampla, tem avançado com o avanço das contradições inerentes à sociedade capitalista. Os homens e a sociedade passaram a ser percebidos como máquinas e engrenagens que têm seu funcionamento predeterminado permitindo o avanço de uma visão fragmentada e parcial da realidade como referenda o pensamento baseado na ciência positivista (Fonseca; Egry; Bertolozzi, 2006).

Na saúde coletiva, segundo Bertolozzi e Fracolli (2004), as práticas sanitárias deverão ter combinações tecnológicas distintas para enfrentar as questões de saúde em um determinado território e, logo, organizar o processo de trabalho em saúde. Neste há que ser considerada também a participação dos diferentes sujeitos nos processos histórico e socialmente determinados.

As entrevistadas percebem que a realidade de saúde que enfrentam está além dos adoecimentos que são expressos pelos indivíduos, mas para desenvolver intervenções recorrem ao que dispõem concretamente em seus trabalhos e em suas capacidades pessoais. Ao fazerem isso se comprometem com as demandas dos usuários e desenvolvem intervenções que estão além do que está prescrito nas diretrizes, princípios e normatizações dos programas e protocolos. Utilizam a referência de modelos e estratégias já implantados em outros serviços e promovem intervenções que acreditam ser resolutivas. A questão que se coloca, em toda a reflexão construída neste estudo, é que não referiram sobre os processos determinantes nas diferentes dimensões da realidade. Não houve reflexão sobre como atuam nos processos que determinam as realidades dos seus trabalhos para modificá-las e, assim, modificar também as realidades de trabalho nas Unidades de Saúde. Acredita-se que com este processo não reflexivo poderão perpetuar uma maneira de agir eticamente comprometida com a equipe e com o usuário, mas sem os recursos necessários para atender às reais necessidades em saúde dos usuários e sem promover transformações estruturais nas realidades descritas.

A parceria com a família para promover a intervenção foi referida pelas entrevistadas como um meio para ajudar o usuário a reconhecer os seus problemas de saúde e, assim, auxiliar a equipe de saúde no enfrentamento deles. A possibilidade de ajuda da família seria pelo estímulo à adesão do 
usuário ao tratamento e pela realização dos cuidados no domicílio. Nas situações descritas não foram referidas parcerias no sentido de desenvolver a compreensão sobre a determinação social dos agravos na dimensão estrutural e particular, ao contrário se afirmou que os usuários e as suas famílias deveriam se responsabilizar mais pelo enfrentamento de suas questões de saúde.

A responsabilização dos sujeitos para enfrentarem suas situações de saúde, conforme apontaram as entrevistadas, deve ser com reflexão sobre os processos que determinam as realidades encontradas e os limites que existem no financiamento para as intervenções desenvolvidas pela equipe da Unidade de Saúde pela indefinição no financiamento do SUS e pela imposição de se fazer o mínimo em programas de saúde com amplas coberturas. Portanto, como responsabilizar as famílias para a transformação de suas realidades uma vez que Políticas Públicas não são promotoras de condições dignas de vida e autonomia para as classes mais pobres? A desigualdade social é concreta na realidade de grupos e indivíduos excluídos do trabalho, com a reprodução social comprometida pela inequidade ${ }^{10}$ social.

$\mathrm{Na}$ análise dos discursos das Conferências ocorridas nos últimos dez anos a responsabilização dos indivíduos e famílias para o desenvolvimento do autocuidado e adoção de estilo de vida mais saudável como medidas para a promoção da saúde e enfrentamento ao agravo esteve presente nas propostas aprovadas nos eventos. Em relação ao desenvolvimento dessas medidas pelos sujeitos houve também propostas para a corresponsabilização do profissional da equipe local de saúde sobre os processos nos quais deveriam promover a saúde, prevenir o adoecimento e estimular a adesão do usuário ao tratamento. A partir da $6 .{ }^{a}$ Conferência, com a aprovação de propostas para a atualização e adoção de protocolos na Secretaria Municipal de Saúde, essas recomendações ficam mais evidentes no discurso. Logo, o enfoque também é norteador dos protocolos de saúde vigentes e analisados.

Atividades de educação à saúde foram apontadas como possibilidade para intervenções de promoção da saúde e prevenção de doenças. Para as

10 Conforme referenda Breilh (2006). 
entrevistadas, essas atividades seriam por meio de orientações individuais, com família ou grupos de usuários. A metodologia poderia ser de dinâmica de grupo ou oficinas com temas específicos ou direcionados para segmentos populacionais. Outra possibilidade eram as palestras com temas previamente definidos para atender à demanda identificada em diferentes espaços que necessitassem como escolas, ambientes de trabalho, reunião de movimento social organizado ou visitas domiciliárias que tivessem como objetivo a realização de orientações para a saúde. Os segmentos populacionais citados foram: idosos, gestantes e crianças.

As metodologias também foram citadas para intervenções junto aos grupos de dependentes químicos. Para essas intervenções as entrevistadas contavam com o auxílio dos profissionais da área da Saúde Mental, como já mencionado anteriormente. Outras intervenções relacionadas à prevenção e ao controle de adoecimentos citadas foram: atuar junto à rede de proteção da criança e adolescente; monitorar condições de higiene de casas; verificar as condições de higiene das ruas da comunidade; identificar famílias de riscos por meio de busca ativa de portadores de doenças crônicas e infectocontagiosas; realizar consultas de enfermagem para usuários, orientar para o autoexame de mama e coletas de material para o preventivo de câncer de colo de útero.

No discurso sobre atividades de educação em saúde para promoção da saúde e o autocuidado as entrevistadas foram coerentes com as propostas de intervenções aprovadas nas Conferências de Saúde. Nos eventos as propostas aprovadas indicaram que o desenvolvimento dessas ações era para determinados grupos populacionais e para os portadores de doenças com risco para desenvolver complicações. Nos protocolos e programas analisados também se encontram ações e atividades de educação em saúde para serem desenvolvidas nos serviços de atenção básica, junto aos usuários, seguindo o referencial teórico do risco para o desenvolvimento de adoecimentos e suas complicações e, ainda, como uma atividade que tem o objetivo de promoção da saúde e da vida com qualidade.

Segundo as compreensões sobre as atividades de educação à saúde, nos diferentes discursos, pode-se afirmar que estas ao serem desenvolvidas 
para indivíduos ou grupos de pessoas identificadas por alguma característica, principalmente com riscos para adoecimentos ou suas complicações, produziriam alguma transformação no processo saúde-doença dos envolvidos pela orientação ao autocuidado e às mudanças recomendadas para suas realidades. Esta compreensão evidentemente direcionada à dimensão singular da realidade do processo saúde-doença reforça a não conscientização dos indivíduos sobre os processos que determinaram a situação em que se encontram. Assim, mudanças até podem ocorrer, mas ficariam na aparência do fenômeno, sem proporcionar a construção de reflexões para transformações em processos relacionados às dimensões particular e estrutural.

A articulação com outros setores e serviços de saúde de outros níveis de complexidade para promoverem intervenção foi referida no enfrentamento de questões instaladas. Nos relatos as ações citadas foram para acionar serviços de outro nível de complexidade de atenção à saúde para garantir acesso à assistência necessária, no caso eram serviços especializados ou com maior complexidade tecnológica para intervir. Os órgãos de outros setores eram articulados para se buscar soluções e recursos para modificar as precárias situações de vida dos usuários portadores de agravos e por meio destas articulações acessos e recursos conseguidos possibilitavam a diminuição do sofrimento dos usuários. Os recursos referidos eram relacionados a programas sociais que garantiam alimentos, cuidados no domicílio, inserção em trabalho e renda.

Por fim, as intervenções no domicilio foram para casos atendidos pelos profissionais de unidades de saúde que tinham ou não ESF implantada. Para as entrevistadas, o desenvolvimento dessas intervenções era para usuários que necessitavam de ações curativas por serem acamados ou porque não podiam se locomover dos domicílios por debilidade física. Dessa forma, com o objetivo de promover o tratamento e a recuperação destes usuários realizavam os procedimentos, orientavam a equipe e a família para que houvesse continuidade nos cuidados. Em alguns casos havia necessidade de materiais específicos e para conseguir buscavam-nos junto aos responsáveis da Secretaria de Saúde, Distrito Sanitário, bem como em outras instituições que os disponibilizavam. 
Para os usuários idosos atendidos pelas equipes com intervenções nos domicílios, citaram que os profissionais de enfermagem realizaram curativos e medicações endovenosas com controle contínuo. Outras intervenções desenvolvidas nos domicílios foram para usuários que não aderiam aos tratamentos prescritos, como já mencionados anteriormente neste capítulo. Nestes casos a equipe de saúde buscou junto aos familiares constituir grupo de apoio com o objetivo de ajudar o usuário no seguimento do tratamento.

Em relação aos discursos que apontaram as intervenções desenvolvidas pelas entrevistadas, observa-se que em muitos momentos estas vão além daquilo que estava previsto nas normatizações dos serviços (normas, protocolos e programas). Segundo Egry, Marques e Fonseca (2006), o desempenho das atividades permite reconhecer as competências do profissional, assim como os saberes mobilizados para o enfrentamento da situação concreta de trabalho.

Zarifian (2003) coloca que o desafio do modelo de competência está em romper com a lógica do trabalho humano fragmentado, repetitivo e alienado. Para Ramos (2002), este modelo exige tornar a organização do trabalho mais flexível, considerando as relações entre as variáveis do procedimento e as relações da personalidade do trabalhador, das relações interpessoais entre os trabalhadores no processo de produção que tem como objetivo os resultados desejados.

Uma das preocupações destacada por Ramos (2002) com o modelo de competência é a formação do trabalhador por meio de aprendizagem na experiência do trabalho. Acredita que a formação do profissional deva ser contínua baseada em referenciais e saberes que permitam a conquista da autonomia e não sua adaptação às condições socioeconômicas impostas pelo capitalismo tardio. Ressalta a importância da formalização do conhecimento técnico necessário ao exercício da profissão porque defende que as ordenações das relações de trabalhos e das relações educativas são socialmente construídas e garantem às pessoas condições para que vivam do seu trabalho. Para a autora, a valorização de competências individuais dos trabalhadores atenderia ao modelo individual, liberal no qual se perde a importância dos elementos da participação, da formação da consciência de classe e da possibilidade de transformar determinadas realidades. 


\subsection{OS RECURSOS UTILIZADOS PARA O ENFRENTAMENTO DAS NECESSIDADES EM SAÚDE RECONHECIDAS}

Os recursos utilizados para desenvolver intervenções de enfrentamento às necessidades em saúde nas situações nas quais estas foram reconhecidas pelas entrevistadas foram: recursos da Unidade de Saúde para planejar e desenvolver intervenções; recursos de outros serviços de saúde para o desenvolvimento de intervenções; articulação com instituições, técnicos e programas de outros setores como recursos para intervenção; recursos comunitários para a intervenção; recursos da família e dos usuários para o desenvolvimento da intervenção; recursos da enfermeira para o desenvolvimento de intervenções em saúde; dificuldades de recursos para o desenvolvimento da intervenção.

Os recursos descritos na Unidade de Saúde foram desde a gestão local até materiais, equipamentos e estrutura física disponíveis para garantir a execução de intervenções. Os gestores da Secretaria Municipal e Distritos Sanitários, assim como os programas de saúde, foram apontados como facilitadores no processo para viabilizar desde insumos até os profissionais para compor a equipe local. Para o planejamento, desenvolvimento e acompanhamento das intervenções, a equipe local foi descrita como fundamental. Os programas de saúde ou atividades programáticas foram lembrados como recursos que possibilitam o desenvolvimento de atividades de promoção da saúde e de prevenção de doenças para grupos específicos, como já comentados anteriormente. Com relação às intervenções para a cura e prevenção de adoecimentos o enfoque foi para os insumos previstos e disponibilizados para os usuários cadastrados nos programas de saúde vigentes na Secretaria de Saúde Municipal.

A percepção das entrevistadas de que os programas possibilitam recursos para atender às necessidades em saúde dos usuários é coerente com o discurso das Conferências e dos próprios protocolos dos programas de saúde que prevêem alocação destes recursos para atender aos usuários cadastrados. Estes são parte da parcela da população geral considerada de 
risco que já desenvolveram o agravo ou suas complicações. Assim, como já referido neste capítulo, a atenção à saúde segundo esta lógica não garante acesso para as pessoas segundo as necessidades percebidas por elas mesmas, mas sim pelas necessidades em saúde reconhecidas em usuários inscritos em programas de saúde que têm enfoque em adoecimentos ou ciclos de vida.

Quando fizeram referência aos recursos disponibilizados por outros serviços de saúde as entrevistadas descreveram os Serviços Públicos de Saúde e os serviços credenciados ao SUS. O destaque foi para o apoio técnico recebido dos profissionais lotados nestes níveis do sistema de saúde na busca de ajuda para desenvolver intervenções mais complexas nas unidades de saúde ou no domicílio do usuário. Os casos relatados eram de usuários portadores de doença mental, doenças crônicas com complicações e com demandas para urgências clínicas e emergências. Para as entrevistadas, o apoio do técnico do especialista Ihes permitia executar a intervenção com mais segurança e eficácia. Outra questão relacionada ao apoio dos serviços foi quanto à disponibilidade de algum material específico necessário para que pudessem desenvolver intervenção curativa. Assim, os Programas de Saúde foram novamente referidos como recursos por garantir o atendimento dos usuários em serviços de alta complexidade, pois por meio da programação em saúde está previsto o acesso a ações, atividades, procedimentos e insumos que permitiam atender às demandas dos sujeitos inscritos.

A articulação com instituições, técnicos e programas de outros setores como recursos para intervenção foi citada em diferentes situações descritas pelas entrevistadas. Nestas se percebe que o objetivo era garantir atendimentos para questões que iam além da expressão biológica do adoecimento. Nos casos relatados, a articulação era para buscar acesso a emprego, renda, alimentação, inclusão de portadores de deficiências e combate à violência. Entre as instituições referidas havia serviços públicos de outros setores e organizações não governamentais. Estas últimas eram de natureza religiosa, cultural e educacional. 
As demandas eram para atendimentos imediatos pela implicação que esta tinha na vida do usuário. No discurso percebe-se que as entrevistadas se sentem responsáveis e comprometidas para buscar uma solução que retire o usuário do risco à saúde, às vezes do risco sobre a vida, nesse sentido mobilizam todas as possibilidades de que dispõem, mas demonstraram saber que naquelas realidades terão continuamente demandas como as que relatavam.

Os recursos comunitários para a intervenção em saúde foram descritos pelo potencial de mobilização da comunidade em geral, assim como o movimento social organizado e o voluntariado, quando havia necessidade de ajuda financeira ou de materiais diversos para alguma família, como também para desenvolver cuidado no domicílio para um usuário portador de deficiência ou idoso acamado.

Anteriormente, neste capítulo, se comentou acerta da compreensão que emergiu sobre o movimento social organizado. $\mathrm{Na}$ análise anterior, no discurso sobre os recursos comunitários, apontou-se que esses movimentos atendiam às demandas dos usuários com recursos que dispunham. $O$ atendimento era feito em situações de escassez ou ausência daquilo que se necessitava nas instituições públicas locais. Somado a esta questão, nos resultados sobre os discursos das Conferências se identificou uma formatação técnica em propostas aprovadas e que estas foram as bases para se estabelecer protocolos de saúde ou para a reformulação de outros. Portanto, indaga-se: como tem sido desempenhado o papel dos movimentos sociais organizados para expor ao setor, aos gestores e aos serviços de saúde as necessidades em saúde daqueles que representam e fazer com que estas sejam atendidas por Políticas Públicas?

Ao referendar um discurso técnico e ao atenderem demandas pela ausência de recursos que deveriam estar disponíveis para os usuários dos serviços o movimento social organizado pode estar deixando de exigir o atendimento às necessidades em saúde daqueles que moram naquele território. Não caberia o não atendimento a uma solicitação, se há o recurso disponível e ele está sendo solicitado, mas como esse processo vai ser 
apresentado na discussão do setor para que se organizem os serviços de saúde no sentido de atender a essas necessidades.

Os recursos da família e dos usuários para o desenvolvimento da intervenção foram relacionados às possibilidades econômicas para a aquisição de medicamentos prescritos e também às suas condições de moradia. Segundo as entrevistadas, sem a disponibilidade dos recursos do próprio usuário ou da sua família seria difícil garantir o tratamento e o cuidado necessários em alguns casos relatados. Outra questão que emergiu do discurso foi que a capacidade de compreensão sobre o funcionamento do Sistema Público de Saúde era um recurso do usuário e da família necessário para o desenvolvimento da intervenção. Os casos relatados destacaram a capacidade do indivíduo para compreender procedimentos burocráticos, encaminhamentos, fluxos relacionados aos atendimentos dos serviços de saúde para tratamentos específicos ou especializados entre outras questões.

Os recursos das enfermeiras para o desenvolvimento de intervenções em saúde foram descritos nas entrevistas quando falavam das situações nas quais identificavam os outros recursos já descritos acima e, em seguida, percebiam os conhecimentos que mobilizaram para desenvolver as ações de enfrentamentos aos agravos. Assim, identificaram como recursos os conhecimentos que desenvolveram nas graduações, a capacidade de mobilizá-los diante das necessidades em saúde das famílias, o desenvolvimento de habilidades para determinados procedimentos e a criatividade que tinham no uso de recursos.

Houve relato de dificuldades de recursos para o desenvolvimento da intervenção quando referiram aos recursos que disponibilizavam para intervir. Portanto, a opção foi destacar essa dificuldade também como um recurso, uma vez que, ao relatar a ausência ou precariedade de algum equipamento ou material necessário para determinada intervenção, a entrevistada descrevia que buscava outros recursos para realizá-la. As dificuldades foram relacionadas pela falta materiais para o desenvolvimento de intervenções na Unidade de Saúde; entre estes, os mais citados foram: falta de profissionais na equipe, espaço físico insuficiente ou inadequado às atividades que tinham para desenvolver e dificuldade de acesso a transporte para usuários que utilizam 
serviços de referência. Sendo que a insuficiência ou inadequação de espaço físico foi relacionada à atividade específicas da enfermeira, consulta de enfermagem, que deveria ser desenvolvida rotineiramente na Unidade de Saúde para os usuários inscritos nos programas de saúde, conforme preveem os protocolos.

Em relação às condições para o desenvolvimento da consulta de enfermagem, não houve referência ao uso da CIPESC $®$ como recurso para a intervenção em saúde, sendo que a classificação possibilita o uso de diagnóstico e intervenções de enfermagem para serem acionados em consultas aos usuários dos programas da saúde da mulher e da criança, usuários que foram citados em muitos dos casos relatados nas entrevistas. Porém, como a maioria dos casos foi referida na família e na comunidade reflete-se sobre a limitação do próprio roteiro de entrevista. Este introduz para o entrevistado as necessidades em saúde da família desde a primeira questão e, assim, pode ter induzido a entrevistada a não explorar as situações atendidas nas consultas de enfermagem e consequentemente o uso da CIPESC $®$. Com esta observação sobre o uso da Classificação não referida neste estudo, decidiu-se que o tema deve ser explorado em investigação a partir do encerramento desta.

Zarifian (2003) aponta que o profissional competente possui autonomia e condições de solucionar com originalidade e criatividade os problemas e desafios que se apresentam no trabalho ao buscar informação, conhecimentos, habilidades, emoções e valores. Ao contrário, ele dependeria da orientação do profissional que coordena as atividades ou de consulta ao manual de procedimentos para realizar as atividades necessárias na intervenção do evento. Acrescenta-se a esta reflexão a definição de Konder (1981, p.8) sobre dialética como sendo "[...] o modo de pensarmos as contradições da realidade, o modo de compreendermos a realidade como essencialmente contraditória e em permanente transformação [...]". Por entender que na compreensão da totalidade o homem identifica as contradições historicamente construídas na determinação e constituição do fenômeno. 
A compreensão ampla sobre a realidade permite ao sujeito refletir criticamente sobre sua determinação e, assim, preestabelecer uma realidade desejada ou a ser atingida. A visão sobre a situação a ser enfrentada, fundamentada em referencial teórico crítico-reflexivo, possibilita que o sujeito tenha compreensão sobre a totalidade, a historicidade e a dinamicidade que constitui o fenômeno observado. Logo, com a intervenção se objetiva construir um projeto transformador a realidade indesejada para em seguida reconhecer a nova realidade e seguir transformando-a e transformando a si mesmo. A seguir na Figura 16 a representação da síntese desta discussão.

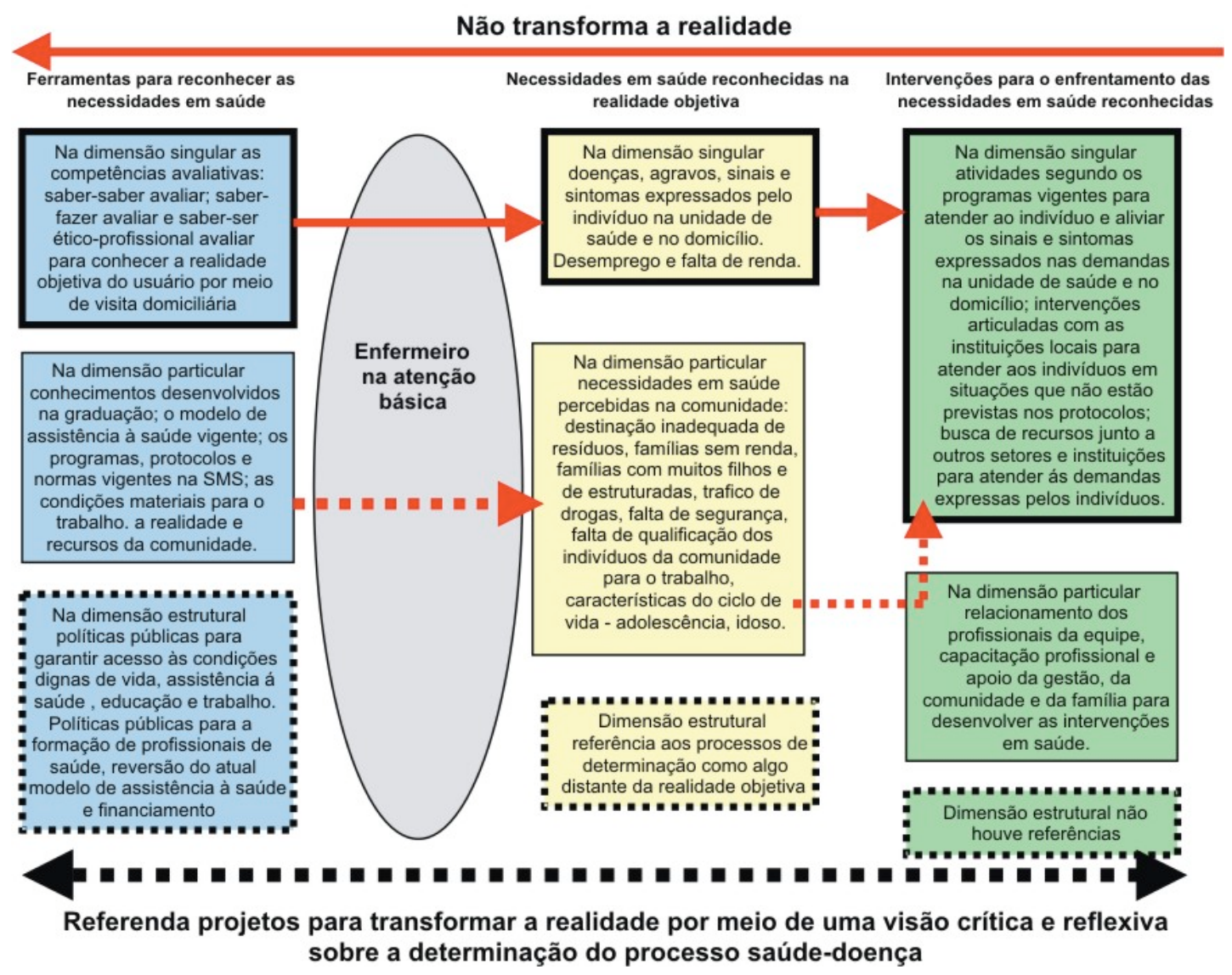

Figura 16 - Síntese da ação do enfermeiro na atenção básica no processo de reconhecer e enfrentar as necessidades em saúde

Fonte: Análise dos discursos dos sujeitos da pesquisa 


\title{
8.5 A COMPETÊNCIA AVALIATIVA DO ENFERMEIRO PARA O RECONHECIMENTO E ENFRENTAMENTO DAS NECESSIDADES EM SAÚDE NA ATENÇÃO BÁSICA À SAÚDE
}

\author{
Baseado no conhecimento construído foi elaborado o Quadro 7, \\ apresentado a seguir, que identifica os saberes avaliativos do enfermeiro da \\ atenção básica necessários para reconhecer e intervir segundo as necessidades \\ em saúde das famílias de um determinado território.
}

Quadro 7 - Saberes avaliativos do enfermeiro da atenção básica necessários para avaliação e enfrentamento de necessidades em saúde das famílias

\begin{tabular}{|c|c|c|}
\hline & & \\
\hline $\begin{array}{l}\text { onhecer os dados demográficos } \\
\text { epidemiológicos relacionados } \\
\text { s necessidades em saúde das } \\
\text { mílias. } \\
\text { teragir com famílias e usuários } \\
\text { ara reconhecer necessidades } \\
\text { m saúde. } \\
\text { rganizar o processo de trabalho } \\
\text { m saúde. } \\
\text { rganizar o processo de trabalho } \\
\text { a enfermagem } \\
\text { tilizar recursos comunicacionais } \\
\text { serviço de saúde. } \\
\text { entificar as instituições e } \\
\text { quipamentos sociais presentes } \\
\text { território. } \\
\text { romover ações intersetoriais. } \\
\text { iscernir necessidades em saúde } \\
\text { âmbito da governabilidade } \\
\text { a setor saúde. } \\
\text { entificar instrumentos para o } \\
\text { conhecimento e enfrentamento }\end{array}$ & $\begin{array}{l}\text { - Visão de mundo materialista } \\
\text { histórica e dialética. } \\
\text { - Reprodução social: geopolítica, } \\
\text { classe social, gênero, etnia e } \\
\text { geração. } \\
\text { - Saúde Coletiva. } \\
\text { - Enfermagem em Saúde Coletiva. } \\
\text { - Determinação social do processo } \\
\text { saúde-doença. } \\
\text { - Concepção de necessidades } \\
\text { - Teoria da Intervenção Práxica } \\
\text { da Enfermagem em Saúde } \\
\text { Coletiva (TIPESC). } \\
\text { - A face individual e coletiva do } \\
\text { - Cuidado em enfermagem. } \\
\text { - Concepção dialética da família. } \\
\text { - Eioestatística. } \\
\text { - Epidemiologia social. } \\
\text { - Comunicação interpessoal e } \\
\text { - Educação emancipadora. } \\
\text { - Constituição Federal de } 1988 \text { e }\end{array}$ & $\begin{array}{l}\text { - Compreender o âr } \\
\text { ações de enferm } \\
\text { produção de serviço } \\
\text { - Mobilizar saberes p } \\
\text { contextos e saber toma } \\
\text { - Interagir com o } \\
\text { seus familiares, dem } \\
\text { atenção às várias } \\
\text { manifestação de su } \\
\text { sidades e demandas } \\
\text { - Perceber, compre } \\
\text { respeitar-se como } \\
\text { como trabalhador de } \\
\text { - Demonstrar respor } \\
\text { para com usuários } \\
\text { nas situações de trak } \\
\text { - Interagir com equipe } \\
\text { de acordo com os v } \\
\text { regem o trabalho de en } \\
\text { - Respeitar os direitos d } \\
\text { como cidadãos. } \\
\text { - Compreender e po } \\
\text { diante das condições }\end{array}$ \\
\hline
\end{tabular}
unidade.

- Requalificar os instrumentos trabalho em saúde e em de avaliação das necessidades enfermagem.

em saúde utilizados no processo - Concepção marxista do processo de trabalho em saúde.

de trabalho.

- Trabalhar em equipe de saúde - Dialética do processo de trabalho e enfermagem.

- Prestar assistência de enfer- - Trabalho em equipe. magem aos grupos sociais do - Legislação do trabalho. território.

- Lei do Exercício Profissional:

- Operar a Classificação atribuições e regulamentação da Internacional das Práticas de Sistematização da Assistência Enfermagem em Saúde de Enfermagem (SAE). Coletiva (CIPESC $®)$.

- Políticas Públicas e de saúde.

- Articular com movimento social - Bioética. organizado. 
conclusão

Quadro 7 - Saberes avaliativos do enfermeiro da atenção básica necessários para avaliação e enfrentamento de necessidades em saúde das famílias

\begin{tabular}{|c|c|c|}
\hline Saber-fazer & Saber-saber & Saber-ser ético profissional ${ }^{(1)}$ \\
\hline $\begin{array}{l}\text { - Estimular o controle social. } \\
\text { Identificar a resolubilidade de } \\
\text { cada âmbito do sistema de saúde } \\
\text { local. } \\
\text { - Mobilizar saberes para avaliar } \\
\text { e enfrentar as necessidades em } \\
\text { saúde no âmbito da unidade. } \\
\text { - Reconhecer as condições de } \\
\text { trabalho e os recursos existentes } \\
\text { na unidade de saúde para } \\
\text { desenvolver intervenções em } \\
\text { situações nas quais foram } \\
\text { reconhecidas necessidades } \\
\text { em saúde. } \\
\text { - Identificar recursos das comu- } \\
\text { nidades e das instituições locais } \\
\text { para utilizar nas intervenções } \\
\text { em saúde. }\end{array}$ & $\begin{array}{l}\text { - Rotinas, normas, manuais, } \\
\text { procedimentos, informações } \\
\text { estatísticas, protocolos utilizados } \\
\text { nos serviços de saúde, base } \\
\text { Classificação Internacional das } \\
\text { Práticas de Enfermagem em } \\
\text { Saúde Coletiva (CIPESC®). } \\
\text { - Intersetorialidade no trabalho } \\
\text { em saúde: educação, trabalho, } \\
\text { assistência social, meio ambiente, } \\
\text { habitação, saneamento. } \\
\text { - Modelos tecno-assistenciais. } \\
\text { Instrumentos assistenciais da } \\
\text { enfermagem: consulta de } \\
\text { enfermagem, visita domiciliária, } \\
\text { atendimentos, procedimentos, } \\
\text { Sistematização da Assistência } \\
\text { de Enfermagem (Classificação } \\
\text { Internacional das Práticas de } \\
\text { Enfermagem em Saúde Coletiva } \\
\text { (CIPESC } ®), \text { entre outros. } \\
\text { - Organização dos movimentos } \\
\text { sociais. }\end{array}$ & \\
\hline
\end{tabular}

Fonte: Análise dos discursos dos sujeitos da pesquisa

(1) Baseado em Marques (2007) e Ribeiro (2009). Os significados do saber-ser ético-profissional encontram-se no Apêndice D. 


\section{CONSIDERAÇÕES FINAIS}

Este estudo permitiu investigar qual a competência avaliativa do enfermeiro para o reconhecimento e o enfrentamento das necessidades em saúde das famílias moradoras das áreas de abrangências das unidades de saúde da atenção básica do Distrito Sanitário Boa Vista em Curitiba-Paraná, por meio do reconhecimento das as ações do enfermeiro na atenção básica, análise das temáticas das situações em que foram reconhecidas e enfrentadas necessidades em saúde, descrição do conjunto de ferramentas que o enfermeiro mobiliza nas situações de reconhecimento e enfrentamento de necessidades em saúde e pela elaboração do instrumento, segundo as temáticas evidenciadas, para identificar a(s) competência(s) avaliativa(s) do enfermeiro na atenção básica para o reconhecimento e enfrentamento das necessidades em saúde.

Para desenvolver a compreensão sobre o objeto selecionado, investigaram-se outras dimensões da realidade para explorar o processo de avaliação das necessidades em saúde realizado pelo enfermeiro da Unidade de Saúde, assim como identificar os determinantes do processo saúdedoença da população moradora da área selecionada. Nesse sentido, buscou-se caracterizar as condições de vida dos munícipes de Curitiba e da Regional Boa Vista, compreender sobre as intervenções em saúde aprovadas nas Conferências Municipais de Saúde ocorridas ao longo dos últimos dez anos segundo os Relatórios Finais de cada evento, analisar o discurso dos programas e protocolos vigentes na Secretaria Municipal de Saúde de Curitiba e os discursos das enfermeiras sobre como reconheciam e enfrentavam as necessidades em saúde das famílias moradoras do território do Distrito Sanitário Boa Vista.

A base teórica que constituiu o discurso analítico foi elaborada com referenciais fundamentados no pensamento crítico e no Materialismo Histórico e Dialético. A metodologia foi ancorada na Teoria da Intervenção Práxica da Enfermagem em Saúde Coletiva (TIPESC), da qual foram 
desenvolvidas as duas primeiras etapas: conhecimento da realidade objetiva e Interpretação da realidade objetiva.

A discussão dos dados permitiu compreender que a competência avaliativa do enfermeiro da atenção básica do Distrito Boa Vista para o reconhecimento e enfrentamento das necessidades em saúde das famílias estava relacionada às dimensões da competência: saber-saber avaliar, saber-fazer avaliar e saber-ser ético profissional que foram mobilizados nas situações nas quais o profissional buscava reconhecer e enfrentar alteração na dinâmica de relacionamento familiar diante de um agravo ou de um evento novo vivido pelo grupo, como também em situações com usuários portadores de adoecimentos já diagnosticados ou que viviam em condições de risco para desenvolver agravos. O discurso dos sujeitos foi convergente com o discurso dos protocolos de saúde vigentes na Secretaria Municipal de Saúde e com os discursos das Conferências de Saúde dos últimos dez anos. Compreende-se que nos três discursos o reconhecimento de necessidades em saúde esteve relacionado aos agravos desenvolvidos e identificados nos perfis epidemiológicos.

No reconhecimento das necessidades em saúde as ferramentas que o profissional utilizava eram os conhecimentos desenvolvidos em sua graduação, as diretrizes e orientações dos protocolos e programas de saúde vigentes, a observação direta da enfermeira sobre a realidade objetiva das famílias nas visitas domiciliárias e nas vistas às comunidades, a discussão de casos com a equipe de saúde local, o relato dos agentes comunitários e auxiliares de enfermagem sobre observações realizadas nas vistas domiciliárias e o relato de representantes da comunidade ou responsáveis por instituições locais sobre situações de carecimento, agravos ou risco para desenvolver um dano à saúde nas famílias moradoras do território.

O referencial teórico que o enfermeiro mobilizou no reconhecimento de necessidades em saúde, saber-saber avaliar, foi baseado na epidemiologia de risco, ou seja, as probabilidades de desenvolvimento de dano à saúde do usuário e da família pelas condições de vida observadas na realidade objetiva. No discurso dos sujeitos identificou-se que foi na dimensão singular da realidade que ocorreu o reconhecimento das necessidades em saúde, 
com ênfase para os aspectos biológicos do adoecimento. Apesar de terem demonstrado no discurso que tiveram percepção sobre processos existentes na dimensão particular e estrutural determinantes do agravo observado em algumas das situações relatadas, as enfermeiras não descreveram reflexões e intervenções sobre os mesmos, ao contrário, em seus discursos sobre intervenções realizadas reforçaram a ênfase nos aspectos biológicos, psicológicos e sociais da família diante do agravo. Sendo que a compreensão sobre os aspectos sociais do processo saúde-doença observados os relacionou a algo não concreto e distante daquela realidade objetiva.

Nesta perspectiva, o profissional avaliou e propôs intervenção sem considerar os determinantes da realidade objetiva. $O$ enfoque da intervenção ficou restrito aos aspectos biológicos relacionados ao agravo, ao atendimento de algum carecimento identificado ou mesmo de orientação sobre o risco para o dano à saúde do usuário ou da família. O modelo de intervenção seguido pelas entrevistadas não Ihes permitiu elaboração de propostas para intervir na determinação da realidade e, assim, a transformação da realidade. A ênfase foi para que os sinais, sintomas e queixas fossem atendidos de imediato.

A visita domiciliária e as visitas à comunidade foram citadas como atividades que permitiam ao profissional observar o aspecto social do usuário $\mathrm{e}$ de sua família perante um agravo ou situação indesejada. A compreensão sobre o social que seria observado se restringiu à percepção do profissional sobre as possibilidades da família para consumir produtos e bens para uma vida com condições mínimas. As condições observadas não foram relacionadas aos processos existentes nas dimensões estruturais e particulares; ao contrário, a realidade objetiva foi descrita como comum ou natural para as comunidades em questão. Ao que se pode afirmar como um processo de naturalização da realidade de exclusão social em determinadas comunidades em consequência de uma visão simplificada. Esta talvez pela própria dificuldade em lidar com questões que iam além das condições materiais que tinham no trabalho para intervir e transformar a realidade encontrada.

Apesar das dificuldades descritas, o profissional mostrou-se comprometido eticamente com os indivíduos e as famílias moradoras do 
território sob sua responsabilidade. Em muitos casos relatados, percebe-se que o comprometimento profissional e pessoal no desenvolvimento de intervenções foi além do que estava normatizado nos programas e protocolos em saúde. Porém, como se descreveu anteriormente, ao compreender o fenômeno como produto da realidade objetiva a intervenção desenvolvida se deteve ao que estava mais aparente, privilegiando as ações de assistência mais imediatas e possíveis naquela realidade.

Segundo a caracterização do município, as necessidades em saúde reconhecidas nos três discursos estão distantes dos processos determinantes das condições de vida das famílias moradoras do território. Os dados analisados permitiram evidenciar processos estruturais históricos determinantes no modo de viver da população do território estudado. Nestes processos o não acesso ao trabalho e consequentemente a exclusão social poderiam ser percebidos no modelo de produção e nas Políticas Públicas adotadas no Estado, mas o reconhecimento de necessidades em saúde só ocorreu em dados que tornaram visíveis os desgastes dos indivíduos na dimensão singular. Os determinantes no modo de vida dos indivíduos no território não foram considerados nas intervenções estabelecidas pelos programas vigentes no setor, bem como não estiveram contemplados nas propostas de intervenção aprovadas nas Conferências estudadas.

As condições de vida descritas mostraram que a lógica do modelo econômico agroexportador adotado em uma sociedade de um país periférico à economia capitalista mundial estimulou a produção da área rural para a monocultura para o comércio internacional de grãos e nas áreas urbanas o desenvolvimento industrial tardio seguiu concentrado em cinco polos estaduais. Atualmente os municípios sedes destes polos têm as maiores densidades populacionais do Estado e, ao seu redor, o crescimento de municípios dependentes para o desenvolvimento socioeconômico com significativo crescimento populacional relacionado à migração da população rural que veio em busca de trabalho. Porém, a falta de preparo para os postos de trabalho oferecidos pelo comércio e indústrias instalados nos territórios urbanos leva os indivíduos a viverem em condições precárias ao redor dos 
municípios sedes. Como exemplo deste movimento se tem a mesorregião metropolitana de Curitiba.

Neste processo de exclusão social se tem como uma das consequências a organização dos migrantes em comunidades homogêneas localizadas nas regiões periféricas ou em áreas de ocupação irregular nas áreas urbanas dos territórios municipais. Os indivíduos à sua maneira passaram a ocupar áreas que não tinham mínimas condições para a instalação de moradias uma vez que não podiam adquirir moradias em áreas regulares ou centrais. Outras questões evidenciadas pelos dados da caracterização foram os índices relacionados à violência presentes nestas comunidades. Dentre estes se teve o aumento de taxas de morbi-mortalidade por causas externas de jovens do sexo masculino.

Os processos de desgastes aos quais os indivíduos estão submetidos podem ser percebidos em situações de vulnerabilidade presentes nos discursos das enfermeiras. Porém, no discurso dos programas e protocolos vigentes o enfoque predominante foi de risco para o desenvolvimento do adoecimento ou dano à saúde. Assim, o desenvolvimento do adoecimento foi compreendido como consequência do estilo de vida dos indivíduos, pela falta de autocuidado e de responsabilidade sobre o seu processo saúde-doença. E como analisado anteriormente os programas de saúde são norteadores da prática em saúde e, consequentemente, passaram também a direcionar os discursos tanto das Conferências como dos sujeitos deste estudo, pois nas intervenções descritas o enfoque foi sobre a importância da mudança das situações pela mudança em comportamentos considerados de risco.

Compreende-se que indivíduos sem acesso ao trabalho e consequentemente à renda não conseguiriam atender às suas necessidades necessárias por não terem como adquirir condições mínimas para a sua sobrevivência, assim como de sua família. Estes se tornam, muitas vezes, dependentes de Políticas Públicas assistenciais com ações para atender às necessidades necessárias dos indivíduos. A contradição é que mesmo sendo ações para atender às necessidades imprescindíveis para a vida estas têm sido descontinuadas e focalizadoras. Logo, nos últimos anos o indivíduo tem adequado suas necessidades aos programas apresentados 
como de inclusão social e diminuição das desigualdades. O desenvolvimento de tais ações ocorre, na grande maioria, por meio de transferência de recursos públicos ou de recursos de organismos internacionais para organizações não governamentais seja de natureza filantrópica, religiosa ou do movimento social organizado.

Os recursos que mobilizaram nos serviços da Secretaria Municipal de Saúde também foram coerentes com a concepção biológica do processo saúde-doença, sendo que os programas foram reconhecidos como potencializadores de acesso aos insumos e materiais necessários para as intervenções que desenvolviam. Esta concepção também foi coerente com a história do Sistema Único de Saúde no município, pois este avançou no sentido de implantar um sistema integrado hierarquizado, regionalizado e resolutivo para questões relacionadas aos adoecimentos identificados nos índices epidemiológicos, como ficou demonstrado no capítulo de resultados, mas que ainda tem o desafio de avançar no enfoque das intervenções em saúde para reconhecer necessidades em saúde percebidas pelas famílias e pelos usuários. Ainda em relação aos recursos que utilizavam na intervenção chamou a atenção que não houve referência para o uso da CIPESC $\circledast$ nas consultas de enfermagem dos programas de atenção à mulher e à criança, grupos prioritários nos programas de saúde implantados. Compreende-se a classificação é um recurso que coadjuva para o reconhecimento dos processos de desgastes e de fortalecimento presentes nas famílias e nos usuários. Este recurso ao ser utilizado nas consultas de enfermagem permitiria o registro sistematizado e a consolidação de dados que evidenciariam o trabalho do enfermeiro na atenção básica em saúde. Neste caso, como já registrado no capítulo de resultados, cabe refletir se ao perguntar sobre o reconhecimento das necessidades em saúde das famílias a própria entrevista pode ter direcionado as respostas.

A iniciativa e criatividade do trabalhador perante um evento dependem de recursos internos e recursos coletivos. Os recursos internos são aqueles que o próprio indivíduo adquire e desenvolve ao longo de sua formação pessoal e profissional e os recursos coletivos são aqueles que a organização da empresa disponibiliza para o desempenho dos trabalhadores - os 
aperfeiçoamentos, as formações e as relações e o apoio de colegas. Para o desempenho diante de um evento inesperado o trabalhador dependerá da mobilização dos seus recursos internos para escolher o melhor modo de agir, mas, sobretudo, dependerá dos recursos disponibilizados pela empresa ou instituição.

$\mathrm{Na}$ busca de resolver os problemas o trabalhador avalia a situação, os recursos necessários e, com as possibilidades que dispõe, julga se será viável intervir ou não. Logo, julga continuamente se conseguirá atingir os resultados desejados no sentido de mudar a situação que havia encontrado inicialmente. Nesse sentido, no setor saúde é preciso que os profissionais desenvolvam a compreensão crítico-reflexiva sobre os fenômenos observados na realidade objetiva para compreenderem os processos determinantes do processo saúde-doença dos indivíduos, famílias ou grupos, segundo as relações de gênero, classe social e culturas presentes em um território em um determinado tempo histórico para que proponham intervenções comprometidas com um projeto de transformação da realidade.

Quanto aos limites do presente estudo se destaca a complexidade da fundamentação teórica baseada no Materialismo Histórico e Dialético para explorar as dimensões do objeto estudado. Ao mesmo tempo ao se refletir sobre o limite observado se compreende a potencialidade do estudo, pois se acredita ser necessário compreender as múltiplas dimensões de um objeto para ultrapassar a visão contemplativa e, assim, construir uma proposta de transformação da realidade, portanto não se percebe como explorar este objeto com um referencial diferente do selecionado. A importância de continuar com investigações sobre os processos determinantes da competência avaliativa do enfermeiro para reconhecer e enfrentar as necessidades em saúde das famílias em um determinado território nas diferentes dimensões da realidade também é uma potencialidade, uma vez que a aproximação aqui relatada aponta novas inquietações. Nessa perspectiva, foi elaborado o Quadro 7 que identifica os saberes avaliativos do enfermeiro da atenção básica necessários para reconhecer e intervir segundo as necessidades em saúde das famílias de um determinado território. 
Por fim, acredita-se que o estudo contribui para a enfermagem em saúde coletiva, uma vez que nesta caminhada foram possíveis algumas reflexões sobre os processos determinantes da competência avaliativa do enfermeiro da atenção básica em saúde e, nestes logicamente, se pensou muito sobre a formação do enfermeiro para atuar na saúde coletiva, área em que atuam as pesquisadoras envolvidas e que, com certeza, será diferente após este estudo. 


\section{REFERÊNCIAS}

Altino, DM, Apostolico MR, Duarte FO, Cubas MR, Egry EY. CIPESC $®$ : o trabalho da enfermagem no distrito Bairro Novo. Rev Bras Enferm. 2006;59(4):502-8.

Ayres JRCM. Epidemiologia e emancipação. São Paulo - Rio de Janeiro: Hucitec - Abrasco; 1995a.

Ayres JRCM. O enfoque de risco na programação em saúde: fundamentos e perspectivas. Rev Saúde Soc.1995b;4(1/2):71-4.

Ayres JRCM. Sobre o risco: para compreender a epidemiologia. São Paulo: Hucitec; 1997.

Barata RB. Desigualdade social e saúde. In: Campos GWS, Minayo MCS, Akerman M, Drumond Junior M, Carvalho YM, organizadores. Tratado de saúde coletiva. São Paulo - Rio de Janeiro: Hucitec - Abrasco; 2006. p.459-86.

Barata RCB. A historicidade do conceito de causa. In: Carvalheiro JR, organizador. Textos de Apoio. Epidemiologia 1. Rio de Janeiro: Programa de Ensino Continuado, Escola Nacional de Saúde Pública, Abrasco; 1985. p.1325.

Barata RCB. Epidemiologia social. Rev Bras Epidemiol. 2005;8(1):7-17.

Bardin L. Análise de conteúdo. Ed. rev. actual. Lisboa-Portugal: Edições 70; 2008.

Bertolozzi MR, Fracolli LA. Vigilância à saúde: alerta continuado em saúde coletiva. O Mundo da Saúde. 2004;28(1):14-20.

Brasil. Constituição 1988. Constituição da República Federativa do Brasil. Brasília (DF): Senado; 1988.

Brasil. Ministério da Saúde. Conselho Nacional de Saúde. 11. ${ }^{\text {a }}$ Conferência Nacional de Saúde: o Brasil falando como quer ser tratado: efetivando o SUS: acesso, qualidade e humanização na atenção à saúde e com controle social. Relatório Final. Série histórica do CNS. Brasília, DF: Ministério da Saúde; 2000;(1). 
Brasil. Conselho Nacional de Secretários de Saúde. Para entender a gestão do SUS. Conselho Nacional de Secretários de Saúde. Brasília: CONASS; 2003.

Brasil. Ministério da Saúde. Secretaria Executiva. Departamento de Apoio à Descentralização. Coordenação-Geral de Apoio à Gestão Descentralizada. Diretrizes operacionais dos pactos pela vida, em defesa do SUS e da gestão. Brasília: Editora MS; 2006.

Brasil. Ministério da Saúde. Secretaria de Vigilância em Saúde. Departamento de Análise de Situação em Saúde. série G. Estatística e informação em saúde. Brasília: Ministério da Saúde, 2007.

Breilh J. Reprodução social e investigação em saúde coletiva: construção do pensamento em debate. In: Costa DC, organizadora. Epidemiologia teoria e objeto. São Paulo: Hucitec-Abrasco; 1990. p.137-65.

Breilh J. Epidemiologia crítica: ciência emancipadora e interculturalidade. Rio de Janeiro: Hucitec; 2006.

Breilh J, Tillería Y. Aceleración global y despojo en Ecuador: El retroceso Del derecho a La vida y La salud pública en las décadas neoliberales. QuitoEquador: Universidad Andina Simón Bolívar/Abya-Ayla; 2009.

Campelli MGR, Calvo MCM. O cumprimento da Emenda Constitucional n. ${ }^{\circ} 29$. Cad Saúde Pública. 2007;23(7):1613-23.

Campos GWS. Subjetividade e administração de pessoal: considerações sobre modos de gerenciar o trabalho em equipes de saúde. In: Merhy EE, Onocko R, organizadores. Agir em saúde: um desafio para o público. São Paulo: Hucitec; 1997. p.229-66.

Campos GWS. O anti-Taylor: sobre a invenção de um método para co-governar instituições de saúde produzindo liberdade e compromisso. Cad Saúde Pública. 1998;14(4);863-70.

Campos GWS, Barros RB, Castro AM. Avaliação de política nacional de promoção à saúde. Rev Ciência e Saúde Coletiva. 2004;9(3):745-9.

Carvalho Al. Conselhos de saúde no Brasil: participação cidadã e controle social. Rio de Janeiro: FASE/IBAM; 1995. 
Carvalho Al. Conselhos de saúde, responsabilidade pública e cidadania: a reforma sanitária como reforma do estado. In: Fleury S, organizadora. Saúde e democracia: a luta do CEBES. São Paulo: Lemos Editorial; 1997. p.93-111.

Carvalho IG, Santos L. Sistema único de saúde: comentários à lei orgânica da saúde (Lei n. ${ }^{\circ}$ 8.080/90 e Lei n. ${ }^{\circ}$ 8.142/90). São Paulo: Hucitec; 1992.

Chaves MMN. Concepções de usuários do serviço local de saúde de uma comunidade agroindustrial sobre o processo saúde-doença [dissertação]. Florianópolis (SC): Universidade Federal de Santa Catarina, Escola de Enfermagem; 2000.

Chiesa AM. A equidade como princípio norteador da identificação de necessidades no controle dos agravos respiratórios na infância [tese]. São Paulo: Universidade de São Paulo, Faculdade de Saúde Pública; 1999.

Chizzotti A. Pesquisa em ciências humanas e sociais. São Paulo: Cortez; 1991.

Cohn A. Estado e sociedade e as reconfigurações do direito à saúde. Rev Ciência \& Saúde Coletiva. 2003;8(1):9-18.

Cohn A, Nunes E, Jacobi P, Karsch US. A saúde como direito e como serviço. 2. ${ }^{a}$ ed. São Paulo: Cortez; 1999.

Conselho Nacional de Saúde. Resolução n. ${ }^{\circ}$ 196, de 10 de outubro de 1996. Diretrizes e normas regulamentadoras de pesquisa envolvendo seres humanos. Bioética. 1996;4 Supl 2:15-25.

Cortes SMV. Construindo a possibilidade da participação dos usuários: conselhos e conferências no Sistema Único de Saúde. Sociologias. 2002;4(7):18-49.

Cowley S, Houston A. Contradictory agendas in health visitor needs assessment. A discussion paper of its use for prioritizing, targeting a promoting health. Primary Health Care Research and Development. 2004;5:240-54.

Cowley S, Mitcheson J, Houston A. Structuring health needs assessments: the medicalization of health visiting. Sociol Health IIIn. 2004;26(5):503-26. 
Curitiba. Prefeitura Municipal de Curitiba. Secretaria Municipal de Saúde. Conselho Municipal de Saúde. Relatório da 4. ${ }^{\text {a }}$ Conferência Municipal de Saúde - Sistema Único de Saúde, saúde pública com qualidade. Curitiba; 1997.

Curitiba. Prefeitura Municipal de Curitiba. Secretaria Municipal de Saúde. Conselho Municipal de Saúde. Relatório final da $5 .^{a}$ Conferência Municipal de Saúde - SUS no III milênio em defesa da vida. Curitiba; 1999a.

Curitiba. Secretaria Municipal de Saúde. Manual de Práticas de Enfermagem. Secretaria Municipal da Saúde. Curitiba; $1999 \mathrm{~b}$.

Curitiba. Secretaria Municipal de Saúde. Crescendo com saúde: infecções e alergias respiratórias na infância. Curitiba; 2000a. [citado 2009 fev.]. Disponível em: http://sitesms.curitiba.pr.gov.br/saude/.

Curitiba. Secretaria Municipal de Saúde. Manual de controle de infecção. Secretaria Municipal da saúde. Comissão de Garantia de Qualidade. Curitiba; 2000b.

Curitiba. Prefeitura Municipal de Curitiba. Secretaria Municipal de Saúde. Conselho Municipal de Saúde. Relatório da 6. ${ }^{a}$ Conferência Municipal de Saúde - Plano Municipal de Saúde de Curitiba 2002-2005. Curitiba; 2001.

Curitiba. Secretaria Municipal de Saúde. Programa Viva Mulher em Curitiba: controle do câncer de mama e colo de útero. Curitiba; 2002a. [citado 2009 fev.]. Disponível em: http://sitesms.curitiba.pr.gov.br/saude/.

Curitiba. Secretaria Municipal de Saúde. Protocolo Integrado: saúde mental em Curitiba. Curitiba; 2002b. [citado 2009 fev.]. Disponível em: http://sitesms.curitiba.pr.gov.br/saude/.

Curitiba. Prefeitura Municipal de Curitiba. Secretaria Municipal de Saúde. Conselho Municipal de Saúde. Relatório final da 7. ${ }^{a}$ Conferência Municipal de Saúde - 15 anos do SUS Curitiba, conquistas, avanços e desafios. Curitiba; 2003.

Curitiba. Secretaria Municipal de Saúde. Programa Mãe Curitibana: prénatal, parto, puerpério e atenção ao recém-nascido. Curitiba; 2004a. [citado 2009 fev.]. Disponível em: http://sitesms.curitiba.pr.gov.br/saude/. 
Curitiba. Secretaria Municipal de Saúde. Protocolo de emergências e urgências em obstetrícia nas maternidades vinculadas ao programa Mãe Curitibana. Curitiba; 2004b. [citado 2009 fev.]. Disponível em: http://sitesms.curitiba.pr.gov.br/saude/.

Curitiba. Secretaria Municipal de Saúde. Hipertensão: protocolo de atenção à hipertensão arterial sistêmica. Curitiba: Secretaria Municipal de Saúde; 2004c.

Curitiba. Secretaria Municipal de Saúde. Fisioterapia. Curitiba; 2004d. [citado 2009 fev.]. Disponível em: http://sitesms.curitiba.pr.gov.br/saude/.

Curitiba. Secretaria Municipal de Saúde. Protocolo Integrado de Atenção à Saúde Bucal. Curitiba; 2004e. [citado 2009 fev.]. Disponível em: http://sitesms.curitiba.pr.gov.br/saude/.

Curitiba. Secretaria Municipal de Saúde. Boletim Epidemiológico de Curitiba. Curitiba; 2005a; XVI, (1).

Curitiba. Prefeitura Municipal de Curitiba. Secretaria Municipal de Saúde. Conselho Municipal de Saúde. Relatório final da $8 .{ }^{a}$ Conferência Municipal de Saúde - a participação popular na construção de um viver saudável. Curitiba; 2005b.

Curitiba. Secretaria Municipal de Saúde. Saúde e prevenção nas escolas: a experiência de Curitiba. Curitiba; 2005c. [citado 2009 fev.]. Disponível em: http://sitesms.curitiba.pr.gov.br/saude/.

Curitiba. Secretaria Municipal de Saúde. Planejamento Familiar - programa Mãe Curitibana. Curitiba; 2005d. [citado 2009 fev.]. Disponível em: http://sitesms.curitiba.pr.gov.br/saude/.

Curitiba. Secretaria Municipal de Saúde. Memento terapêutico da farmácia curitibana. Curitiba; 2005e. [citado 2009 fev.]. Disponível em: http://sitesms.curitiba.pr.gov.br/saude/.

Curitiba. Secretaria Municipal de Saúde. Boletim Epidemiológico de Curitiba. Curitiba; 2006a; XVII, (1).

Curitiba. Secretaria Municipal de Saúde. Boletim epidemiológico de Curitiba. Curitiba; 2006b; XVII, (2). 
Curitiba. Secretaria Municipal de Saúde. Protocolo de atenção à saúde do adolescente. 2. ${ }^{\text {a }}$ ed. rev. atual. Curitiba; 2006c.

Curitiba. Secretaria Municipal de Saúde. Alfabetizando com saúde: temas para alfabetização de adultos. Curitiba; 2006d. [citado 2009 fev.]. Disponível em: http://sitesms.curitiba.pr.gov.br/saude/.

Curitiba. Secretaria Municipal de Saúde. Acidentes loxocélicos: protocolo técnico e fluxo de atenção em Curitiba. Curitiba; 2006e. [citado 2009 fev.]. Disponível em: http://sitesms.curitiba.pr.gov.br/saude/.

Curitiba. Secretaria Municipal de Saúde. Manual de Fluoterapia. Curitiba; $2006 f$. [citado 2009 fev.]. Disponível em: http://sitesms.curitiba.pr.gov.br/saude/.

Curitiba. Secretaria Municipal de Saúde. Boletim Epidemiológico de Curitiba. Curitiba; 2007a; XVIII, (1).

Curitiba. Secretaria Municipal de Saúde. Alimentação infantil - cartilha de orientação aos pais. Curitiba; 2007b. [citado 2009 fev.]. Disponível em: http://sitesms.curitiba.pr.gov.br/saude/.

Curitiba. Secretaria Municipal de Saúde. AIDS - atendimento inicial ao portador do HIV na unidade básica de saúde. 2. ${ }^{a}$ ed. Curitiba; 2007c.

Curitiba. Secretaria Municipal de Saúde. Cartilha do paciente em terapia nutricional enteral domiciliar. Curitiba, saúde levada a sério. Curitiba; $2007 \mathrm{~d}$. [citado 2009 fev.]. Disponível em: http://sitesms.curitiba.pr.gov.br/saude/.

Curitiba. Secretaria Municipal de Saúde. Como ajudar o seu paciente a parar de fumar: protocolo de orientações para o profissional de saúde na abordagem mínina do fumante. Curitiba; 2007e. [citado 2009 fev.]. Disponível em: http://sitesms.curitiba.pr.gov.br/saude/.

Curitiba. Secretaria Municipal de Saúde. Boletim epidemiológico de Curitiba. Curitiba; 2008a; XIX.

Curitiba. Secretaria Municipal de Saúde. Boletim Epidemiológico de Curitiba. Curitiba; 2008b (ed. esp.). 
Curitiba. Prefeitura Municipal de Curitiba. Secretaria Municipal de Saúde. Conselho Municipal de Saúde. Relatório final da 9. ${ }^{a}$ Conferência Municipal de Saúde - saúde e qualidade de vida: política de estado e desenvolvimento. Curitiba; 2008c.

Curitiba. Secretaria Municipal de Saúde. Protocolo da Rede de Proteção à Criança e ao Adolescente em Situação de Risco para a Violência. Curitiba; 2008d. [citado 2009 fev.]. Disponível em: http://sitesms.curitiba.pr.gov.br/saude/.

Curitiba. Secretaria Municipal de Saúde. Atenção à saúde da mulher em situação de violência: Curitiba levada a sério. Curitiba; 2008e.

Curitiba. Secretaria Municipal de Saúde. Imunizações - cartilha de orientações técnicas para a atualização de equipes de enfermagem. 3. ${ }^{a}$ ed. Curitiba; $2008 f$.

Curitiba. Secretaria Municipal de Saúde. Nascer em Curitiba: informações importantes para seu filho. Curitiba; [data desconhecida]. [citado 2009 fev.]. Disponível em: http://sitesms.curitiba.pr.gov.br/saude/.

Curitiba. Secretaria Municipal de Saúde. Protocolo de atenção à Hanseníase em Curitiba. Curitiba; [data desconhecida]. [citado 2009 fev.]. Disponível em: http://sitesms.curitiba.pr.gov.br/saude/.

Doyal L, Gough I. A theory of human need. London: Macmillan; 1991.

Doyal L, Gough I. A theory of human need. London: Macmillan; 1991. [Resenha de: Scherer E. In: Universidade e Sociedade. São Paulo. 1997;VII(12):158-60].

Egry EY. Elementos teórico-metodológicos para a intervenção práxica da enfermagem em saúde coletiva [tese de livre-docência]. São Paulo: Universidade de São Paulo, Programa Doutorado da Escola de Enfermagem da Universidade de São Paulo; 1994.

Egry EY. Saúde coletiva: construindo um novo método em enfermagem. São Paulo: Ícone; 1996.

Egry EY, Marques CM da S, Fonseca RMGS da. A avaliação de competências na perspectiva crítico-emancipatória. Rev Ciênc Cuid Saúde. 2006;5(2):236-42. 
Escorel S. Conselhos de saúde: entre a renovação e a reprodução da cultura política. Saúde para Debate. 2008;43:23-8.

Fachini LA. Por que a doença? A inferência causal e os marcos teóricos de análise. In: Rocha LE, Rigotto RM, Buschinelli JTP, organizadores. Isto é trabalho de gente?: vida, doença e trabalho no Brasil. Petrópolis (RJ): Vozes; 1994. p.33-55.

Faustino RLH. Saberes e competências na formação da enfermeira em saúde coletiva [tese]. São Paulo: Universidade de São Paulo, Escola de Enfermagem da Universidade de São Paulo; 2004.

Fiorin JL. Linguagem e ideologia. 8. ${ }^{\text {a }}$ ed. São Paulo: Ática; 2005.

Fleury S. A questão democrática na saúde. In: Fleury S, organizadora. Saúde e democracia: a luta do CEBES. São Paulo: Lemos Editorial; 1997. p.25-41.

Fonseca RMGS da, Bertolozzi MR. Avaliação do cliente em saúde coletiva: em busca da expressão da unidade dialética homem-sociedade. Saúde em Debate. 1993;(41):24-9.

Fonseca RMGS da, Egry EY, Bertolozzi MR. O materialismo histórico e dialético como teoria da cognição e método para a compreensão do processo saúde-doença. In: Egry EY, Cubas M. organizadoras. O trabalho da enfermagem em saúde coletiva no cenário CIPESC - guia para pesquisadores. Curitiba: ABEn Paraná: Editora Mult-Graphic; 2006. p.19-61.

Foucault M. Microfísica do poder. 3. ${ }^{a}$ ed. Rio de Janeiro: Graal; 1982.

Gentille P. A falsificação do consenso: simulacro e imposição na reforma educacional do neoliberalismo. Rio de Janeiro: Vozes; 1998.

Gohn MG. Empoderamento e participação da comunidade em políticas sociais. Rev Saúde Soc. 2004;13(2):20-31.

Heller Á. Teoría da las necesidades em Marx. 2. ${ }^{a}$ ed. Bracelona: Península; 1986.

IPARDES - Instituto Paranaense de Desenvolvimento Econômico e Social. Famílias pobres no estado do Paraná. Curitiba: IPARDES; 2003. 
IPARDES - Instituto Paranaense de Desenvolvimento Econômico e Social. Leituras regionais: Mesorregião Geográfica Metropolitana de Curitiba.

Curitiba: IPARDES; 2004a.

IPARDES - Instituto Paranaense de Desenvolvimento Econômico e Social. Imagens estatísticas do Paraná: populacionais, saúde, infra-estrutura, finanças públicas, eleitorais, educacionais, renda e emprego, agro-pecuária, década de 1990. Curitiba: IPARDES; 2004b.

IPARDES - Instituto Paranaense de Desenvolvimento Econômico e Social. Caderno estatístico: município de Curitiba. Curitiba; 2008.

IPPUC - Instituto de Pesquisa e Planejamento Urbano. Regional Boa Vista: monitorização. Curitiba; 2005.

IPPUC - Instituto de Pesquisa e Planejamento Urbano. Curitiba em dados. [citado 2008]. Disponível em: http://ippucnet.ippuc.org.br/Bancodedados/ Curitibaemdados/Curitiba_em_dados_Pesquisa.asp.

Konder L. O que é dialética. 8. ${ }^{a}$ ed. São Paulo: Brasiliense; 1981.

Labra ME. É possível aferir a qualidade da representação dos usuários nos conselhos de saúde? Saúde para Debate. 2008;43:106 -17.

Laurell AC. A saúde-doença como processo social. In: Nunes ED, organizador. Medicina social: aspectos históricos e teóricos. São Paulo: Global; 1983. p.133-58.

Leonello V. Competências para a ação educativa do enfermeiro: uma interface entre o ensino e a assistência de enfermagem [dissertação]. São Paulo (SP): Escola de Enfermagem da USP; 2007.

Luiz OC, Cohn A. Sociedade de risco e risco epidemiológico. Cad Saúde Pública. 2006;22(11):2339-48.

Marques CMS. As competências crítico-emancipatórias e a formação dos trabalhadores do nível médio em enfermagem: focalizando as políticas ministeriais [dissertação]. São Paulo (SP): Escola de Enfermagem da USP; 2007.

Marx K. O capital. 8. ${ }^{a}$ ed. São Paulo: Difel; 1985. t.1, v1. 
Mendes EV. A reengenharia do sistema de serviços de saúde. In: Mendes EV, organizador. A organização da saúde no nível local; 1998. p.57-86.

Mendes EV. Distrito sanitário - o processo social de mudanças das práticas sanitárias do sistema único de saúde. $4 .^{a}$ ed. São Paulo - Rio de Janeiro: Hucitec - Abrasco; 1999.

Mendes-Gonçalves RB. Práticas de saúde: processos de trabalho e necessidades. São Paulo: Cefor; 1992.

Mendes-Gonçalves RB. Tecnologia e organização social das práticas de saúde: características tecnológicas de processo de trabalho na rede estadual de centros de saúde de São Paulo. São Paulo: Hucitec-Abrasco; 1994.

Merhy EE. Um dos grandes desafios para os gestores do SUS: apostar em novos modos de fabricar os modelos de atenção. In: Merhy EE, et al. O trabalho em saúde: olhando e experimentando o SUS no cotidiano. São Paulo: Hucitec; 2003. p.15-35.

Minayo MC de S. O desafio do conhecimento: pesquisa qualitativa em saúde. 8. ${ }^{a}$ ed. São Paulo: Hucitec; 2004.

Moreira MR, Escorel S. Conselhos municipais de saúde no Brasil: um debate sobre a democratização da política de saúde nos vinte anos do SUS. Rev Ciência \& Saúde Coletiva. 2009;14(3):795-805.

Nakamura E, Egry EY, Campos CMS, Nichiata LYI, Chiesa AM, Takahashi RF. The potential of an instrument to identify social vulnerabilities and health needs: collective health knowledge and practices. Rev Latino-am Enfermagem. 2009;17(2):253-8.

Nojima D, Moura R, Silva ST. Dinâmica recente da economia e transformações na configuração espacial da região metropolitana de Curitiba. Curitiba: IPARDES; 2004.

Oliveira MAC, Egry EY. A historicidade das teorias interpretativas do processo saúde doença. Rev Esc Enferm USP. 2000;34(1):9-15. 
Paim JS. Reorganização das práticas de saúde em distritos sanitários. In: Mendes EV, organizador. Distrito Sanitário: o processo social de mudança das práticas sanitárias do Sistema Único de Saúde. $4{ }^{2}{ }^{a}$ ed. São Paulo - Rio de Janeiro: Hucitec - Abrasco; 1999. p.187-220.

Paim JS. Vigilância da saúde: dos modelos assistenciais para a promoção da saúde. In: Czeresnia D, Freitas CM de, organizadores. Promoção da saúde: conceitos, reflexões, tendências. Rio de Janeiro: Fiocruz; 2003. p.161-74.

Paim JS. Planejamento em saúde para não especialistas. In: Campos GWS, Minayo MCS, Akerman M, Drumond Júnior M, Carvalho MY de, organizadores. Tratado de saúde coletiva. São Paulo - Rio de Janeiro: Hucitec - Fiocruz; 2006. p. 767-82.

Paraná. Governo do Estado do Paraná. Secretaria de Estado de Segurança Pública. Mapa do Crime - fase I. Curitiba; 2003.

Paraná. Governo do Estado do Paraná. Secretaria de Estado de Segurança Pública. Resultados da pesquisa de vitimização em Curitiba. Curitiba; 2007.

Paraná. Secretaria de Estado da Saúde. Saúde no Paraná - Boletim Epidemiológico. 2009a. IV, (ed. esp.). [citado 2009 maio]. Disponível em: http://200.189.113.52/vigiepi/Boletim_especial/materna.htm.

Paraná. Secretaria de Estado da Saúde. Instituto de Saúde do Paraná. Centro de Informações e diagnóstico em saúde. Departamento de Sistema de Informação em Saúde. Série histórica dos indicadores de natalidade e outros de mortalidade. [citado 2009b]. [citado 2009 maio 15]. Disponível em: http://www.saude.pr.gov.br/arquivos/file/estatisticas/indicadores/estado_para na.xls.

Pierantoni CR. A informação para a gestão local de recursos humanos da saúde: o sistema de informação e gestão de recursos humanos em saúde. In: Brasil, Ministério da Saúde. Observatório de recursos humanos em saúde no Brasil. Brasília (DF): Abrasco - Organização Pan-Americana de Saúde; 2003. p.261-77.

Programa das Nações Unidas (PNUD) - Brasil. Atlas do desenvolvimento humano no Brasil. Brasília; 2003. [citado 2009 mar.]. Disponível em: http://www.pnud.org.br/atlas/ 
Ramos MN. A pedagogia das competências: autonomia ou adaptação. São Paulo: Cortez; 2002.

Rede Interagencial de Informações para a Saúde - RIPSA. Indicadores básicos para a saúde no Brasil: conceitos e aplicações. 2. ${ }^{a}$ ed. Brasília: OPAS; 2008. [citado 2008 jun.]. Disponível em:

http://tabnet.datasus.gov.br/cgi/idb2006/indicadores.pdf.

Ribeiro MC. Competência profissional: a dimensão do saber-ser éticoprofissional nas práticas de saúde das enfermeiras em unidade básica de saúde [dissertação]. São Paulo (SP): Escola de Enfermagem da USP; 2009.

Rosen G. Da polícia médica à medicina social. Rio de Janeiro: Graal; 1980.

Rosen G. Uma história da saúde pública. São Paulo - Rio de janeiro: Hucitec Abrasco; 1994.

Sala AA. avaliação de programas de saúde. In: Schraiber LB, organizadora.

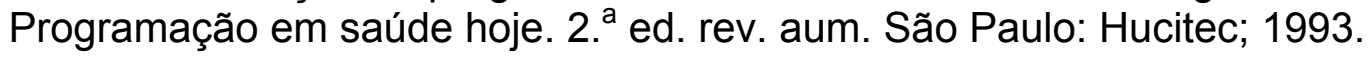
p.29 -65.

Samaja J. Desafíos a la epidemiología - pasos para una epidemiología "Miltoniana". Rev Bras Epidemiol. 2003;6(2):105-20.

Schraiber LB. Programação hoje: a força do debate. In: Schraiber LB, organizador. Programação em saúde hoje. 2. ${ }^{a}$ ed. rev. aum. São Paulo: Hucitec; 1993. p.11-35.

Schraiber LB, Machado MH. Trabalhadores de Saúde: uma nova agenda de estudos sobre recursos humanos em saúde no Brasil. In: Fleury S, organizador. Saúde e democracia: a luta do CEBES. São Paulo: Lemos; 1997. p.281-97.

Schraiber LB, Mendes-Gonçalves RB. Necessidades de saúde e a atenção primária. In: Schraiber LB, Nemes MIB, Mendes-Gonçalves RB, organizadores. Saúde do adulto: programas e ações na unidade básica. São Paulo: Hucitec; 1996. p.29-65.

Stotz EM. Necessidades de saúde mediações de um conceito: contribuição das ciências para a fundamentação teórico-metodológica de conceitos operacionais da área de planejamento em saúde [tese]. Rio de Janeiro: Escola Nacional de Saúde Pública; 1991. 
Stotz EV. Trajetória, limites e desafios do controle social no SUS. Saúde em Debate. 2006;30(73/74):149-60.

Tanguy L. Racionalização pedagógica e legitimidade política. In: Ropé F, Tanguy $L$, organizadores. Saberes e competências: o uso de tais noções na escola e na empresa. Campinas (SP): Papirus; 1997. p.25-67.

Teixeira CM. Epidemiologia e planejamento de saúde. Rev Ciência e Saúde Coletiva. 1999;4:287-303.

Triviños ANS. Introdução à pesquisa em ciências sociais: a pesquisa qualitativa em educação. São Paulo; 1987.

Uribe Rivera FJ. Programação local de saúde, distritos sanitários e enfoque estratégico. In: Uribe Rivera FJ, organizador. Planejamento e programação em saúde: um enfoque estratégico. Rio de Janeiro: Abrasco, 1989. p.177-96.

Valla VV. Educação, saúde e cidadania: investigação científica e assessoria popular. Cad Saúde Pública. 1992;8(1):30-40.

Valla VV. Sobre participação popular: uma questão de perspectiva.

Cad Saúde Pública. 1998;14 Supl 2;7-18.

Valla VV. Educação popular, saúde comunitária e apoio social numa conjuntura de globalização. Cad Saúde Pública. 1999;15 Supl 2;7-14.

Witt RR. Competência da enfermeira na atenção básica: contribuição a construção das funções essenciais em saúde pública [tese]. Ribeirão Preto (SP): Universidade de São Paulo, Escola de Enfermagem da USP - Ribeirão Preto; 2005.

Zarifian P. Objetivo competência: por uma nova lógica. São Paulo: Atlas; 2001.

Zarifian P. O modelo da competência: trajetória histórica, desafios atuais e propostas. São Paulo: Senac; 2003. 


\section{APÊNDICES}




\section{APÊNDICE A}

\section{RAPPORT}

Eu sou Maria Marta Nolasco Chaves, vou colher dados para desenvolver uma pesquisa sobre competência avaliativa do enfermeiro para reconhecer e enfrentar as necessidades de saúde das famílias. Gostaria de saber se $\mathrm{o}(\mathrm{a}) \mathrm{Sr}(\mathrm{a})$ teria interesse e disponibilidade para participar da entrevista. Caso tenha e não se importe, gostaria de gravar as respostas para ficar mais fácil para escrever tudo depois. Se desejar participar e não quiser que seja realizado o registro por meio de gravação este poderá ser realizado pela escrita e depois validado pelo(a) $\mathrm{Sr}(\mathrm{a})$.

Se aceitar participar, vou pedir-Ihe para assinar um Termo de Consentimento Livre e Esclarecido (TCLE) onde você declara que teve interesse e tempo para participar da entrevista. 


\section{APÊNDICE B \\ TERMO DE CONSENTIMENTO LIVRE E ESCLARECIDO (TCLE)}

Você está sendo convidada(o) para participar voluntariamente da pesquisa intitulada "competência avaliativa do enfermeiro para o reconhecimento e enfrentamento das necessidades de saúde das famílias" desenvolvida pela doutoranda Maria Marta Nolasco Chaves da Escola de Enfermagem da Universidade de São Paulo, sob a orientação da Professora Doutora Emiko Yoshikawa Egry, da Escola de Enfermagem da Universidade de São Paulo.

A pesquisa tem o seguinte objetivo: Identificar qual a competência avaliativa do enfermeiro para o reconhecimento e o enfrentamento das necessidades de saúde das famílias em um determinado território.

Sua participação é voluntária e consiste em participar de uma entrevista semi-estruturada com duração aproximada de 30 minutos.

Serão garantidos o seu anonimato e o sigilo das informações.

Suas respostas serão utilizadas para identificação dacompetência avaliativa do enfermeiro em saúde coletiva para reconhecer e enfrentar as necessidades de saúde da população em situações vivenciadas no trabalho, posteriormente será confrontado com a prática do enfermeiro observada nos serviços de saúde do Distrito Boa Vista do Município de Curitiba-Pr por meio de instrumento a ser elaborado.

A entrevista será gravada e the será permitido ouvi-la ou lê-la, depois de transcrita, bem como discutir seu conteúdo junto à pesquisadora, se assim o desejar. Todo o material ficará sob guarda da pesquisadora por um período mínimo de 5 (cinco) anos e os resultados serão utilizados exclusivamente para fins científicos. 
Durante a pesquisa você poderá fazer todas as perguntas que julgar necessárias para o esclarecimento de dúvidas, podendo recusar-se a responder perguntas ou deixar de participar do estudo a qualquer momento, se assim o desejar.

Para aceitar participar da pesquisa nas condições descritas acima, você deve ler e depois assinar a declaração a seguir:

Como participante da pesquisa afirmo que fui devidamente orientada sobre a finalidade e objetivo da pesquisa, bem como sobre a utilização das informações que forneci somente para fins científicos, sendo que meu nome será mantido em sigilo. Minhas dúvidas foram esclarecidas suficientemente e concordo em participar do estudo. Declaro que concordo com a utilização de todos os dados por mim fornecidos, nesta pesquisa.

Local e data

Participante: (nome e assinatura)

Pesquisadora: Maria Marta Nolasco Chaves

Telefones para contato:

(41) 9192 9543; 30147562

Endereço:

Rua Colombo, 868 - casa 3 - Juvevê - Curitiba-PR.

CEP: $80.540-250$ 


\section{APÊNDICE C \\ ROTEIRO PARA ENTREVISTAS SEMI-ESTRUTURADAS}

Título da pesquisa: "Competência avaliativa do enfermeiro para o reconhecimento e enfrentamento das necessidades de saúde das famílias" PESQUISADORA: Maria Marta Nolasco Chaves

PARTICIPANTE:

UNIDADE DE SAÚDE: DATA:

\section{QUESTÕES NORTEADORAS}

1. Como você reconhece necessidade(s) de saúde de uma família moradora da área sob sua responsabilidade?

2. Nesta última semana você realizou algum atendimento no qual reconheceu necessidade de saúde na família? Comente sobre a situação vivenciada.

Suporte - Comente sobre a(s) intervenção(ões) que desenvolveu para enfrentar a(s) necessidade(s) reconhecida(s) na situação descrita anteriormente.

3. Fale sobre a(s) necessidade(s) de saúde mais freqüentes nas famílias moradoras da área sob sua responsabilidade.

4. Comente sobre a(s) intervenção(ões) que você desenvolveu para enfrentar a(s) necessidade(s) reconhecida(s).

5. Fale sobre o(s) recurso(s) que você dispõe para desenvolver intervenção(ões) de enfrentamento em situação(ões) nas quais foram reconhecidas necessidade(s) de saúde. 
APÊNDICE D

\section{SABERES E SIGNIFICADOS DO SABER-SER ÉTICO PROFISSIONAL DO ENFERMEIRO DA ATENÇÃO BÁSICA NECESSÁRIOS PARA A AVALIAÇÃO E ENFRENTAMENTO DE NECESSIDADES EM SAÚDE DAS FAMÍLIAS}

\begin{tabular}{|c|c|}
\hline SABER & SIGNIFICADO \\
\hline $\begin{array}{l}\text { Compreender o âmbito das ações } \\
\text { de enfermagem na produção de } \\
\text { serviço de saúde. }\end{array}$ & $\begin{array}{l}\text { Compreender as finalidades e os objetivos das ações que } \\
\text { realiza; compreender o seu trabalho como totalidade parte do } \\
\text { trabalho de enfermagem e de saúde; reconhecer o âmbito e os } \\
\text { limites da sua atuação profissional e agir de acordo com a } \\
\text { legislação vigente. }\end{array}$ \\
\hline $\begin{array}{l}\text { Mobilizar saberes para avaliar } \\
\text { contextos e saber tomar decisões. }\end{array}$ & $\begin{array}{l}\text { Relacionar o condicionamento e a experiência profissional com } \\
\text { o contexto para enfrentar as situações, avaliando e propondo ao } \\
\text { adotar soluções. }\end{array}$ \\
\hline $\begin{array}{l}\text { Interagir com o usuário e seus } \\
\text { familiares, demonstrando atenção } \\
\text { às várias formas de manifestação } \\
\text { de suas necessidades e demandas. }\end{array}$ & $\begin{array}{l}\text { Compreender a linguagem verbal do usuário percebendo, ouvindo } \\
\text { e compreendendo as razões que motivam suas atitudes e } \\
\text { comportamentos. Esta interação se expressa na adoção de } \\
\text { princípios e valores como: bondade, compaixão, cooperação, } \\
\text { empatia, generosidade, honestidade, humanidade, iniciativa, justiça, } \\
\text { lealdade, respeito, solidariedade e tolerância. }\end{array}$ \\
\hline $\begin{array}{l}\text { Perceber, compreender e respeitar-se } \\
\text { como cidadão e como trabalhador } \\
\text { de saúde. }\end{array}$ & $\begin{array}{l}\text { Ter apreço para consigo mesmo e para com o próprio trabalho, } \\
\text { reconhecer e exercitar seus direitos, sua autonomia e } \\
\text { autodesenvolvimento; respeitar os seus próprios sentimentos, } \\
\text { atitudes e valores éticos-morais considerando o bem-estar e os } \\
\text { direitos dos usuários. }\end{array}$ \\
\hline $\begin{array}{l}\text { Demonstrar responsabilidade para } \\
\text { com usuários e equipe nas situações } \\
\text { de trabalho. }\end{array}$ & $\begin{array}{l}\text { Compreender a maneira subjetiva com que cada trabalhador } \\
\text { apreende as situações de trabalho e se situa em relações à elas, } \\
\text { dimensionando as ações que são necessárias para enfrentá-la. } \\
\text { A responsabilidade se expressa pelo compromisso e reciprocidade } \\
\text { (interação) entre as pessoas envolvidas com um conjunto de } \\
\text { ações, em prol da qualidade da assistência. }\end{array}$ \\
\hline $\begin{array}{l}\text { Interagir com equipe de trabalho de } \\
\text { acordo com os valores que regem } \\
\text { o trabalho de enfermagem. }\end{array}$ & $\begin{array}{l}\text { Pressupõe articular-se com a equipe de trabalho, num movimento de } \\
\text { solidariedade e de compartilhamento, assumindo co-responsabilidade } \\
\text { e reconhecimento das competências dos outros. Visa o eficaz } \\
\text { resultado das ações e procedimentos que realiza. }\end{array}$ \\
\hline $\begin{array}{l}\text { Respeitar os direitos dos usuários } \\
\text { como cidadãos. }\end{array}$ & $\begin{array}{l}\text { Compreender que os usuários têm direito à assistência de } \\
\text { qualidade. Compreender que saúde é direito do usuário, como } \\
\text { cidadão brasileiro, e dever do Estado. Reconhece a autonomia } \\
\text { do usuário em relação à sua própria saúde. }\end{array}$ \\
\hline $\begin{array}{l}\text { Compreender e posicionar-se frente } \\
\text { às condições de trabalho existentes } \\
\text { nas instituições. }\end{array}$ & $\begin{array}{l}\text { Compreender e posicionar-se em relação aos efeitos da } \\
\text { organização e das condições de trabalho sobre os trabalhadores, } \\
\text { usuários e sobre o próprio processo de trabalho em saúde. }\end{array}$ \\
\hline
\end{tabular}

Fonte: Marques (2007) e Ribeiro (2009, p.109) 
ANEXOS 
ANEXO A

PARECER DO COMITÊ DE ÉTICA DA ESCOLA DE ENFERMAGEM DA UNIVERSIDADE DE SÃO PAULO 


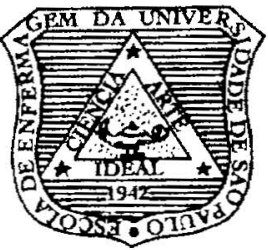

UNIVERSIDADE DE SÃO PAULO

ESCOLA DE ENFERMAGEM

Av. Dr. Enéas de Carvalho Aguiar, 419 - CEP 05403-000

mi Fone.: 3061-7548 - Fax.: 3061-7548

C.P. 41633 - CEP 05422-970 - e-mail.: edipesq@usp.br

São Paulo, 28 de maio de 2008.

Ilm. ${ }^{\mathrm{a}} \mathrm{Sr}^{\mathrm{a}}$

Maria Marta Nolasco Chaves

Ref.: Processo $n^{\circ}$ 740/2008/CEP-EEUSP

Prezada Senhora,

Em atenção à solicitação referente à análise do projeto "Competências avaliativas do enfermeiro para o reconhecimento e enfrentamento das necessidades de saúde das famílias", informamos que o mesmo foi considerado aprovado pclo Comitê de Ética em Pesquisa da Escola de Enfermagem da Universidade de São Paulo (CEP/EEUSP).

Analisado sob o aspecto ético-legal, atende às exigências da Resolução n ${ }^{\circ} 196 / 96$ do Conselho Nacional de Saúde.

Esclarecemos que após o término da pesquisa, os resultados obtidos deverão ser encaminhados ao CEP/EEUSP, para serem anexados ao processo.

Atenciosamente,

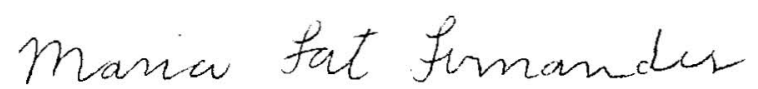

Prof. ${ }^{a}$ Dr. ${ }^{a}$ Maria de Fátima Prado Fernandes

Coordenadora do Comitê de Ética em Pesquisa da

Escola de Enfermagem da Universidade de São Paulo 


\section{ANEXO B \\ PARECER DO COMITÊ DE ÉTICA DA SECRETARIA MUNICIPAL DE SAÚDE DE CURITIBA}




\section{REFEITURA MUNICIPAL DE CURITIBA \\ SECRETARIA MUNICIPAL DA SAÚDE \\ CENTRO DE EDUCAÇÃO EM SAÚDE \\ COMITÊ DE ÉTICA EM PESQUISA}

Curitiba, 09 de julho de 2009.

Of. $09 / 2008$

Prezada Senhora:

Em atenção à sua solicitação referente à análise de concessão de campo de pesquisa para o projeto intitulado: "Competências avaliativas do enfermeiro para o reconhecimento e enfrentamento das necessidades de saúde das famílias" Prot. 65/2008 informamos que o mesmo foi considerado aprovado quanto à viabilidade pelo Comitê de Ética em Pesquisa da Secretaria Municipal de Saúde.

Esclarecemos que após o término da pesquisa, os resultados obtidos deverão ser encaminhados ao CEP/SMS.

\section{Atenciosamente}

Dr. Samuel Jorge Moysés

Coordenador do Comitê de Ética em Pesquisa

da Secretaria Municipal de Curitiba

IIma. Sra.

Maria Marta Nolasco Chaves

Nesta. 